\title{
Reïntegratie na scholing : de brug tussen arbeidsongeschiktheid en arbeidsparticipatie
}

Citation for published version (APA):

van Lierop, B. A. G. (2001). Reïntegratie na scholing : de brug tussen arbeidsongeschiktheid en arbeidsparticipatie. [Doctoral Thesis, Maastricht University]. Elsevier Bedrijfsinformatie. https://doi.org/10.26481/dis.20011005bl

Document status and date:

Published: 01/01/2001

DOI:

10.26481/dis.20011005bl

Document Version:

Publisher's PDF, also known as Version of record

\section{Please check the document version of this publication:}

- A submitted manuscript is the version of the article upon submission and before peer-review. There can be important differences between the submitted version and the official published version of record. People interested in the research are advised to contact the author for the final version of the publication, or visit the DOI to the publisher's website.

- The final author version and the galley proof are versions of the publication after peer review.

- The final published version features the final layout of the paper including the volume, issue and page numbers.

Link to publication

\footnotetext{
General rights rights.

- You may freely distribute the URL identifying the publication in the public portal. please follow below link for the End User Agreement:

www.umlib.nl/taverne-license

Take down policy

If you believe that this document breaches copyright please contact us at:

repository@maastrichtuniversity.nl

providing details and we will investigate your claim.
}

Copyright and moral rights for the publications made accessible in the public portal are retained by the authors and/or other copyright owners and it is a condition of accessing publications that users recognise and abide by the legal requirements associated with these

- Users may download and print one copy of any publication from the public portal for the purpose of private study or research.

- You may not further distribute the material or use it for any profit-making activity or commercial gain

If the publication is distributed under the terms of Article $25 \mathrm{fa}$ of the Dutch Copyright Act, indicated by the "Taverne" license above, 


\section{REÏNTEGRATIE NA SCHOLING}


Vormgeving omslag: Tom Bongers, Eindhoven

O Brigitte van Lierop, Maastricht 2001

Niets van deze uitgave mag worden verveelvoudigd en/of openbaar gemaakt door middel van druk, fotokopie, microfilm of op welke andere wijze dan ook zonder voorafgaande schriftelijke toestemming van de uitgever.

No part of this book may be reproducted in any form, by print, photoprint, microfilm or any other means without written permission from the publisher.

ISBN 9057498944 


\section{REÏNTEGRATIE NA SCHOLING}

De brug tussen arbeidsongeschiktheid en arbeidsparticipatie

\section{PROEFSCHRIFT}

ter verkrijging van de graad van doctor aan de Universiteit Maastricht, op gezag van de Rector Magnificus, Prof. Dr. A.C. Nieuwenhuijzen Kruseman, volgens het besluit van het College van Decanen, in het openbaar te verdedigen op vrijdag 5 oktober 2001 om 16.00 uur.

door

Brigitte Anna Gertruda van Lierop geboren te Weert op 9 januari 1960 


\section{Promotores:}

Prof. dr. F.J.N. Nijhuis

Prof. dr. W.J.A. van den Heuvel

\section{Beoordelingscommissie:}

Prof. dr. J.Th.M. van Eijk (voorzitter)

Prof. mr. A.J.C.M. Geers

Prof. dr. J.W. Groothoff (Rijksuniversiteit Groningen)

Prof. dr. J.A.M. Maarse

Prof. dr. H. Philipsen 


\section{INHOUDSOPGAVE}

1. ARBEIDSONGESCHIKTHEID EN REIINTEGRATIE

1.1 Inleiding

1.2 De wetgeving met betrekking tot reìntegratic

1.3 Reïntegratie in relatie tot de wet

1.4 Arbeidsongeschiktheid

1.5 Medisch model versus sociale constructie gedachte

1.5.1 Medisch model

1.5.2 De sociale constructie van een handicap

1.5.3 Naar een integraal kader

2. FACTOREN VAN INVLOED OP REÏNTEGRATIE

2.1 Persoonsgebonden factoren

2.1.1 Sociaal-demografische kenmerken 25

$\begin{array}{lll}2.1 .2 & \text { Gezondheid } & 29\end{array}$

$\begin{array}{lll}2.1 .3 & \text { Persoonskenmerken } & 30\end{array}$

$2.2 \quad$ Omgevingsgebonden factoren $\quad 33$

2.2.1 Maatschappelijke factoren 33

2.2.2 Factoren gerelateerd aan het proces van reïntegratie 35

$\begin{array}{lll}2.3 & \text { Bedrijfsgebonden factoren } & 38\end{array}$

2.4 Beïnvloedbare factoren 43

$2.5 \quad$ Beroepsgerichte scholing als reïntegratie instrument 46

$2.6 \quad$ Naar een model 49

$\begin{array}{lll}2.7 & \text { Vraagstellingen } & 53\end{array}$ 
3. METHODEN VAN ONDERZOEK

$3.1 \quad$ Inleiding

3.2 Object van onderzoek en onderzoekspopulatie

3.2.1 Procedure en onderzoekspopulatie

3.3 Aard en type onderzoek

3.4 Beschrijving factoren

3.5 Analyse vraagstellingen

4. RESULTATEN: SCHOLING

$4.1 \quad$ Inleiding

$\begin{array}{lll}4.2 & \text { Kenmerken cursistenpopulatie } & 77\end{array}$

$\begin{array}{lll}4.3 & \text { Beschrijving programma } & 84\end{array}$

$\begin{array}{lll}\text { 4.3.1 Assessment } & 84\end{array}$

$\begin{array}{lll}\text { 4.3.2 Vaktheoretisch gedeelte van het scholingsprogramma } & 87\end{array}$

4.3.3 Begeleidings- en ondersteuningscomponent 88

$\begin{array}{lll}\text { 4.3.4 Bemiddeling naar arbeid } & 89\end{array}$

$4.4 \quad$ Evaluatie scholingsprogramma's: toetsing aan de literatuur 90

$\begin{array}{lll}4.5 & \text { Waardering scholingsprogramma }\end{array}$

5. RESULTATEN: PARTICIPATIE 101

$\begin{array}{lll}5.1 & \text { Persoonlijke ontwikkeling } & 101\end{array}$

$\begin{array}{lll}5.2 & \text { Plaatsing } & 103\end{array}$

$\begin{array}{lll}\text { 5.2.1 Plaatsing op korte termijn } & 104\end{array}$

$\begin{array}{lll}5.2 .2 & \text { Plaatsing op lange termijn } & 118\end{array}$

5.3 Functioneren in de werksituatie: werkgeversperspectief 125

$\begin{array}{ll}5.3 .1 & 125\end{array}$

$\begin{array}{ll}\text { 5.3.2 Algemeen en specifiek functioneren } & 129\end{array}$

5.3.3 Werkgeversperspectief: factoren van invloed op blijvende integratie 136

$\begin{array}{lll}5.4 & \text { Kosten versus baten } & 139\end{array}$ 
6. PARTICIPATIE GEANALYSEERD

6.1 Inleiding

6.2 Persoonsgebonden factoren

6.3 Factoren gerelateerd aan het scholingsprogramma

6.4 Relatie binnen participatie

7. DISCUSSIE

163

7.1 Inleiding

7.2 Beantwoording onderzoeksvragen

7.3 Discussie

167

7.4 Beschouwing

SAMENVATTING

SUMMARY

REFERENTIES

BIJLAGE 1

NAWOORD

CURRICULUM VITAE 



\section{ARBEIDSONGESCHIKTHEID EN REÏNTEGRATIE}

\subsection{INLEIDING}

In het jaar 2001, vierendertig jaar na de invoering van de Wet op de Arbeidsongeschiktheid, telt Nederland bijna één miljoen arbeidsongeschikten, in de zin van de Wet op de Arbeidsongeschiktheid (WAO)'. Hoewel dit gegeven zowel onnauwkeurig als onbetrouwbaar is, omdat een gedeelte van deze populatic arbeidsongeschikten nog steeds of weer aan het werk is (Landelijk Instituut Sociale Verzekeringen, 2001), kan wel worden gesteld dat het aantal personen met een arbeidsongeschiktheidsuitkering aanzienlijk groter is dan bij de invoering van de Wet op de Arbeidsongeschiktheid in 1967 verwacht wordt. Geschat wordt toentertijd dat ongeveer 150.000 werknemers gebruik zullen gaan maken van deze regeling.

Als halverwege de tachtiger jaren het aantal personen met een WAO-uitkering oploopt naar 700.000, worden door de overheid de eerste stappen ondernomen in de vorm van nieuwe wet- en regelgeving, om de groei van de WAO-populatic te remmen. Sindsdien zijn velerlei maatregelen ingevoerd met als doel de instroom van de WAO te verminderen en de uitstroom te bevorderen. De genomen maatregelen hebben echter tot nu toe niet tot de verwachte daling geleid. Halverwege de jaren negentig treedt kortstondig een daling van de WAO-populatie op (periode 1994 - 1997), waarna vervolgens weer een stijging is opgetreden die tot op heden in stand is gebleven (LISV, 2000).

In dit eerste hoofdstuk wordt een verklaring voor de toenemende groei in 'WAOgevallen' gezocht in het falen van de tot nu toe genomen maatregelen voor arbeidsreïntegratie (en daarmee tot het falen van de maatregelen gericht op het vergroten van de uitstroom uit de WAO). In paragraaf 1.2 wordt een chronologisch overzicht gegeven van de op de WAO-problematiek van toepassing zijnde wet- en regelgeving, alsmede de hieruit voortvloeiende maatregelen. Tevens wordt in paragraaf 1.3 , in dezelfde chronologische volgorde, de relatie gelegd tussen maatregelen ten aanzien van arbeidsreïntegratie en de wetgeving.

Op basis van dit overzicht zal worden geconcludeerd dat de tot op heden genomen beleidsmaatregelen met name op het systeem van de WAO-uitvoering zijn gericht en

1 Onder WAO worden in dit kader alle regelingen in het kader van langdurige arbeidsongeschiktheid veritaan. 
onvoldoende in staat blijken om het gedrag van werkgevers en werknemers met betrekking tot het proces van reïntegratie te beïnvloeden. Derhalve lijkt het interessant om de aandacht te focussen op maatregelen die rechtstreeks betrekking hebben op de persoon die vanwege een ziekte of aandoening arbeidsongeschikt is verklaard en zijn/haar weg naar de arbeidsmarkt moet (terug)vinden. Van belang daarbij is de wijze waarop de overheid de persoon die vanwege een ziekte of aandoening arbeidsongeschikt is verklaard, ziet.

Ten aanzien van de rol van deze arbeidsongeschikte persoon zal in paragraaf 1.4 worden aangegeven dat de door de overheid 'formeel' arbeidsongeschikt verklaarde persoon, in principe een eigen verantwoordelijkheid draagt ten aanzien van zijn/haar reïntegratie. De gedachtegang die hieraan ten grondslag ligt zal worden beschreven in paragraaf 1.5. Tevens zal in deze paragraaf duidelijk worden dat de visie van de overheid (nog) niet overeenkomt met de maatschappelijke visie op personen met beperkingen. Aan de hand van theorieën over de positie van personen met een beperking in de maatschappij, zal blijken dat maatregelen gericht op de persoon en zijn/haar directe omgeving, reïntegratie kunnen beïnvloeden. Het hoofdstuk zal tenslotte worden afgesloten met een model waarin verschillende factoren (bijvoorbeeld persoonsgebonden factoren) zijn opgenomen, die onafhankelijk en afhankelijk van elkaar hun invloed uitoefenen op de kans op reïntegratie.

Deze factoren zullen in hoofdstuk 2 nader worden gespecificeerd in de vorm van variabelen waarvan bekend is dat ze van invloed zijn op de kans op reīntegratie van personen die vanwege een ziekte of aandoening arbeidsongeschikt zijn verklaard. Daarbij wordt tevens aangegeven of de genoemde factoren al dan niet zelf beînvloedbaar blijken en derhalve onderdeel van beleidsvorming kunnen zijn.

Uit hoofdstuk 2 zal blijken dat slechts een gering aantal buiten de persoon gelegen succesvolle factoren, te beïnvloeden is. Daarentegen zijn interventies gericht op de persoon, succesvol gebleken én bovendien vrij gemakkelijk in te voeren. De kans op succesvolle reïntegratic wordt onder meer positief beïnvloed wanneer (om)scholingsprogramma's worden gevolgd, waarbij aandacht wordt gegeven aan het trainen van persoonlijke, sociale en werkgerelateerde vaardigheden. Tot op heden is het succes van dergelijke (om)scholingsprogramma's niet systematisch onderzocht in Nederland. De centrale vraagstelling luidt dan ook:

In hoeverre leidt het volgen van een (om)scholingstraject tot reĭntegratie en daarmee tot een uitstroom uit de WAO? 
Om deze vraag te beantwoorden is een studie verricht naar het succes van het volgen van langdurige (om)scholingstrajecten door personen die vanwege een ziekte of aandoening een arbeidsongeschiktheiduitkering ontvangen om op die wijze hun kans op de reguliere arbeidsmarkt te vergroten. De totale groep personen in Nederland die gedurende een bepaalde periode een langdurig (om)scholingstraject heeft doorlopen, heeft hierbij als onderzoeksgroepspopulatie gediend.

Aan het einde van hoofdstuk 2 zal het in deze studie gehanteerde onderzocksmodel worden gepresenteerd, alsmede een verdere specificering van de eerste vraagstelling.

Vervolgens zullen in hoofdstuk 3 de in deze studie gehanteerde onderzoeksmethoden worden beschreven, waarna in de hoofdstukken 4,5 en 6 de uit deze studie voortkomende resultaten worden gepresenteerd. Hoofdstuk 7 geeft tenslotte de conclusies weer, alsmede een methodologische en inhoudelijke discussie omtrent de gevonden resultaten. Tot slot zullen in hoofdstuk 7 aanbevelingen worden gedaan voor toekomstig beleid ten aanzien van de reìntegratie van mensen met een arbeidsongeschiktheidsuitkering.

\subsection{DE WETGEVING MET BETREKKING TOT REÏNTEGRATIE}

The disabled encounter without any doubt a number of barriers that prevent them in reaching total economic and social integration. Therefore it is necessary to incorporate their fundamental right on equal chances in all policy measures of the European Union.

(Witboek Europees Sociaal Beleid, 1994)

In de beginperiode van de invoering van de WAO staat het recht op een reële compensatie van gederfde inkomsten voor werknemers die tengevolge van een ongeval of ziekte niet meer in staat zijn te werken, centraal (Aarts \& De Jong, 1990). Deze benadering presenteert een nieuwe optiek op arbeidsongeschiktheid. In de hieraan voorafgaande periode wordt slechts aan die werknemers, die arbeidsongeschikt zijn geworden als gevolg van een bedrijfsongeval of beroepsziekte (risque professionel), een reêle tegemoetkoming in het verlies aan inkomen toegekend. Deze werknemers kunnen een beroep doen op de Ongevallenwet (1901, vervangen in 1921); voor zolang de arbeidsongeschiktheid duurt, ontvangen zij een uitkering van maximaal $80 \%$ van het laatst verdiende loon. Ongevallen of ziekten die niet kunnen worden toegeschreven aan de arbeidssituatie (risque social) worden gedekt door de Invaliditeitswet (1919). 
Personen die hiervoor in aanmerking komen ontvangen een inkomen op minimumloon niveau. De toelatingscriteria voor beide verzekeringen worden omschreven als 'streng, maar rechtvaardig' (Velema, 1993), hetgeen in de praktijk betekent dat slechts een kleine groep personen in aanmerking komt voor een van deze twee uitkeringsvormen. Met de invoering van de Wet op de arbeidsongeschiktheidsverzekering (WAO) in 1967 krijgt iedereen die arbeidsongesçhikt wordt recht op een uitkering. Bij volledige arbeidsongeschiktheid is dit $80 \%$ van het laatst verdiende loon. De uitkering loopt in principe door tot de pensioendatum. Arbeidsongeschikt is hij/zij die wegens ziekte of gebrek niet in staat is te verdienen hetgeen gezonde, aan belanghebbende (= de WAOcliěnt) gelijksoortige personen (= de maatman), met soortgelijke opleiding en ervaring gewoonlijk verdienen. Datgene wat de WAO-cliënt nog kan verdienen met zijn/haar beperkingen, wordt aangeduid als de resterende verdiencapaciteit. Hieronder wordt verstaan, het vermogen van een WAO-cliënt om zich een inkomen te verwerven met arbeid op basis van zijn/haar krachten en bekwaamheden en die hem/haar met het oog op opleiding en vroeger beroep kan worden opgedragen, de zogenoemde 'passende arbeid' (Kers, Van der Stelt, Fiseler \& Molenaar-Cox, 1996).

Omdat de nadelige inkomensgevolgen van arbeidsongeschiktheid door de WAO aanzienlijk kleiner worden in vergelijking met de hiervoor bestaande Invaliditeitswet, heeft de WAO een enorme aantrekkingskracht op zowel werkgevers als werknemers. Daarnaast wordt het de praktijk om iedereen die het Ziektewetjaar ${ }^{2}$ heeft volgemaakt, automatisch door te laten stromen naar de WAO (Hibbeln, 1993), hetgeen een toename van het volume tot gevolg heeft. Bovendien vinden in de jaren zeventig nog enkele verruimingen van deze wet plaats die soms zelfs in strijd zijn met de wetteksten. De verruiming met de meeste impact vindt plaats in 1973 en staat bekend als het 'Monsterverbond' (Stavenuiter, 1999). Deze verruiming bevat een bepaling waarin wordt gesteld dat ".... bij de vaststelling van de mate van arbeidsongeschiktheid, zoveel doenlijk rekening wordt gehouden met de door de arbeidsongeschiktheid veroorzaakte verminderde gelegenheid tot het verkrijgen van arbeid ....". Feitelijk betekent dit dat wanneer iemand gedeeltelijk arbeidsongeschikt is en geen werk heeft, er wordt aangenomen dat er tussen het niet verkrijgen van werk en de handicap van de WAOcliënt in voldoende mate verband aanwezig is, om deze in te delen in de hoogste arbeidsongeschiktheidsklasse (80-100\%).

Met deze bepaling begint de 'verdiscontering van de werkloosheid in de WAO' (Kers et al., 1996). Niet alleen diegenen die in medisch/arbeidskundig opzicht volledig arbeidsongeschikt zijn, maar ook zij die voor een deel arbeidsongeschikt zijn en voor

Gedurende het eerste jaar na uitval vanwege arbeidsongeschiktheid wordt cen ziektewet uitkering verstrekt. 
een deel werkloos, kunnen in de hoogste arbeidsongeschiktheidsklasse worden ingedeeld. Het is mogelijk om met een relatief geringe mate van arbeidsongeschiktheid (15-25\%), onder toepassing van de verdiscontering, binnen de hoogste arbeidsongeschiktheidsklasse te vallen. Dat veel werknemers gebruik maken van de WAO, blijkt uit de explosieve stijging van de instroom in de jaren zeventig. De aantrekkingskracht van de WAO wordt vooral ingegeven door de naar verhouding betere uitkeringsrechten en grotere maatschappelijke acceptatic van de WAO in vergelijking met de werkloosheidsregelingen.

De verdisconteringsbepaling is vanuit het oogpunt van de werknemer met een beperking een aantrekkelijke regeling bij een slechte arbeidsmarkt (aanbod $>$ vraag). Wanneer het gaat over de positie van deze werknemer op de arbeidsmarkt vormt, bij een ruim aanbod, deze regeling geen stimulans om op eigen initiatief zich opnieuw een inkomen door arbeid te verwerven. De overheid erkent de anti-integrerende werking van de verdisconteringsbepaling; de toekenning van een volledige uitkering aan een gedeeltelijk arbeidsongeschikte staat naar de mening van de overheid herintreding in het arbeidsproces in de weg.

In de in 1987 door de regering-Lubbers ingevoerde stelselherziening sociale zekerheid worden voor het eerst maatregelen opgenomen waarvan wordt verwacht dat ze een stimulerende werking hebben voor wat betreft de herintreding van gedeeltelijk arbeidsgeschikten. De nadruk binnen de stelselherziening blijft liggen op het regelen van een goede uitkeringssituatie voor diegenen die daartoe volgens de wet recht op hebben.

De wijzigingen in de WAO waarvan wordt verwacht dat ze het herintredingsproces stimuleren, zijn zowel op de werknemer als op de werkgever gericht. Het verdisconteringscriterium wordt in zijn geheel afgeschaft, waardoor personen die gedeeltelijk arbeidsongeschikt worden verklaard, niet meer een volledige arbeidsongeschiktheidsuitkering ontvangen, maar een uitkering bestaande uit een gedeelte WAO en een gedeelte werkloosheidsuitkering. De geringere aantrekkelijkheid van de werkloosheidsuitkering zal uitkeringsgerechtigden stimuleren om de resterende capaciteiten in te zetten in reguliere betaalde arbeid, aldus de overheid. Bovendien wordt een nieuw artikel opgenomen, artikel 44a WAO: "Indien degene die recht heeft op een arbeidsongeschiktheidsuitkering berekend naar een mate van arbeidsongeschiktheid van minder dan $80 \%$, inkomsten uit arbeid geniet die minder bedragen dan evenredig is aan zijn nog bestaande arbeidsongeschiktheid, is de bedrijfsvereniging bevoegd betrokkene één arbeidsongeschiktheidsklasse hoger in te delen dan de klasse die behoort bij zijn op dat moment bestaande mate van arbeidsongeschiktheid'. De 
bedoeling van het 'opstapje' is de werkgever een loonsubsidie te verschaffen en daardoor te stimuleren tot het in dienst nemen van de persoon met beperkingen.

Een echte stimulatie voor het in dienst nemen van mensen met beperkingen vormt de vlak voorafgaand aan de stelselherziening ingevoerde WAGW (Wet Arbeid Gehandicapte Werknemers, 1986). Kern van de WAGW is de quotumregeling waarin werkgevers worden verplicht om, afhankelijk van de aard en omvang van het bedrijf, drie tot zeven procent (gedeeltelijk) arbeidsongeschikten in dienst te hebben. Daarnaast wordt het instrument 'proefplaatsing' ingevoerd, waardoor de mogelijkheid wordt gecreëerd om werknemers met beperkingen gedurende maximaal twee maanden bij een werkgever werk te laten verrichten, zonder dat daarvoor een beloning wordt ontvangen. Beide instrumenten zijn gericht op de werkgevers. Voor de werknemers met beperkingen wordt de mogelijkheid geschapen via (om)scholing zich weer een positie op de arbeidsmarkt te verwerven. Hiertoe staat hen een scholingsbudget ter beschikking van de Gemeenschappelijke Medische Dienst die binnen de WAGW de arbeidsbemiddelende bevoegdheid krijgt toegekend voor werknemers met beperkingen.

De maatregelen in het kader van de WAGW lijken slechts een beperkte betekenis te hebben gehad voor de bevordering van de herintreding van arbeidsongeschikten. In een onderzoek van Ter Huurne, Maas \& Senders (1990) wordt gemeld dat "in geen enkele bedrijfstak de in de WAGW bij een eventuele quotumverplichting gestelde benedengrens van $3 \%$ wordt gehaald". Bovendien wordt geconstateerd dat voor werknemers met beperkingen van buiten de eigen organisatie weinig tot geen beleidsmatige aandacht bestaat en vrijwel geen activiteiten worden ondernomen.

De stelselherziening in 1987 en de invoering van de WAGW hebben aldus niet geleid tot de verwachte uitstroom uit de WAO. In de beginjaren negentig leidt dit tot het nemen van scherpere maatregelen, waarbij onder meer het bevorderen van de reìntegratie van (gedeeltelijk) arbeidsongeschikten in het arbeidsproces centraal staat, alsmede het vergroten van de financiële betrokkenheid van het bedrijfsleven hierbij. De maatregelen die de overheid heeft voorgesteld die betrekking hebben op het bevorderen van de reïntegratie zijn ondergebracht in twee wetten, de Wet Terugdringing ArbeidsongeschiktheidsVolume (TAV) en de Wet Terugdringing Beroep op de Arbeidsongeschiktheidsregelingen (TBA).

De TAV (1992) bevat maatregelen die werkgevers en werknemers moeten prikkelen zo kort en zo weinig mogelijk een beroep te doen op bijvoorbeeld de WAO. Hiertoe wordt onder meer cen bonus/malus systeem ingevoerd, waarbij een werkgever die een arbeidsongeschikte in dienst neemt, een beloning krijgt en een werkgever een boete krijgt als een werknemer in zijn dienst arbeidsongeschikt wordt en de werkgever geen 
andere arbeid aanbiedt. Daarnaast wordt een loonkostensubsidie ingevoerd voor een werkgever die een (gedeeltelijk) arbeidsongeschikte in dienst neemt (De Vroom \& Willems, 1992).

In de TBA wordt de structuur van de WAO ingrijpend gewijzigd. Wijzigingen, gericht op de werknemer die van invloed zijn op het herintredingsproces, zijn de herziening van het arbeidsongeschiktheidscriterium waarbij het begrip 'passende arbeid' wordt verruimd naar 'gangbare arbeid', aanpassing van de hoogte van de WAO-uitkering aan de leeftijd, tijdelijkheid van de uitkeringsduur gekoppeld aan periodieke herbeoordelingen van de arbeidsongeschikten en financiële stimulansen voor oudere en langdurig arbeidsongeschikten. Al deze maatregelen binnen de TBA zijn gericht op het minder aantrekkelijk maken van het hebben van een WAO-uitkering voor (gedeeltelijk) arbeidsongeschikten en het derhalve 'stimuleren' van (gedeeltelijk) arbeidsongeschikten tot het opnieuw vinden van een betaalde baan op de reguliere arbeidsmarkt.

De nieuwe golf van maatregelen leidt evenwel niet tot de gewenste structurele verlaging van de uitstroom uit de WAO. De tot op heden laatste wetgevingsstap in het beperken van het arbeidsongeschiktheidsvolume en met betrekking tot de reìntegratie van personen met een arbeidshandicap, is de Wet REA. Hiermee wordt beoogd het volume van de arbeidsongeschiktheidsregelingen te reduceren alsmede de procedures rondom reîntegratie activiteiten te vereenvoudigen. De maatregelen in de wet REA hebben betrekking op alle personen die door ziekte of gebrek een afstand hebben tot de arbeidsmarkt. Deze groep wordt aangeduid met het begrip 'arbeidsgehandicapt', waarvan de geheel of gedeeltelijk arbeidsongeschikten deel uitmaken.

De invoering van de wet REA gaat echter niet gepaard met de verwachte daling van het volume. Zowel aan de instroomkant als aan de uitstroomkant zijn er geen aanwijzingen dat er, door de inwerkingtreding van de wet REA, een daling respectievelijk een stijging is opgetreden (Jehoel-Gijsbers \& Van der Giezen, 2000).

3 In de zin van de wet REA wordt als arbeidsgehandicapte aangemerkt:

a. degene met een ZW-. WAO-, WAZ- of Wajong-uitkering:

b. degene aan wie reeds in verband met ziekte of gebrek op grond van wettelijke bepalingen een voorziening of hiermee samenhangende subsidie is verstrekt in verhand met behoud, herstel of bevordering van de arbeidsgeschiktheid:

c. degene die tot de doclgroep van de WSW behoort.

d. degene die niet tot de voorgaande categoriectn behoon, maar van wie medisch-arbeidsdeskundig is vastgesteld, dat hij in verband met zickte of gebrek een belemmering ondervindt om aan het werk te gaan:

f. degene die maximal 5 jaar geleden onder $a, b, c$ of $d$ viel: arbeidstijd hoeft te solliciteren 


\subsection{REÏNTEGRATIE IN RELATIE TOT DE WET}

De wijze waarop beleidsmatig wordt omgegaan met reïntegratie is vrijwel geheel afhankelijk van de hierop afgestemde wet- en regelgeving. Binnen de wet- en regelgeving worden instrumenten genoernd die een stimulans moeten vormen voor de reïntegratie van mensen met een WAO-uitkering. De ontwikkelingen ten aanzien van reïntegratie en de instrumenten die hiervoor worden ingezet, kunnen in nauwe relatie worden gezien met de ontwikkelingen op het gebied van wet- en regelgeving.

Gedurende de eerste twee decennia na invoering van de WAO worden er geen eisen gesteld aan uitkeringsontvangers. De uitvoeringsorganisaties stellen zich tot doel uitkeringen te verstrekken op een zo efficiënt mogelijke manier. Indien een persoon met een arbeidsongeschiktheidsuitkering een baan weigert die wordt aangeboden, kunnen geen sancties worden opgelegd. Verplichte uitstroom naar arbeid vindt vrijwel niet plaats; personen stromen alleen dan uit de WAO wanneer ze op eigen initiatief een baan vinden, de pensioengerechtigde leeftijd bereiken of overlijden. In die zin kunnen de bedrijfsverenigingen in de jaren ' 60 en ' 70 worden gezien als 'uitkeringsfabrieken' (Parlementaire enquête, 1993). De verantwoordelijkheid van de bedrijfsverenigingen voor de terugkeer naar de arbeidsmarkt, beperkt zich tot het eerste ziektewetjaar, daarna neemt Arbeidsvoorziening deze verantwoordelijkheid over. Arbeidsvoorziening heeft gedurende de periode tot de jaren ' 80 deze verantwoordelijk ervaren als zijnde een papieren verantwoordelijkheid en derhalve ook zo gehandeld (Parlementaire enquête, 1993). De reïntegratie van mensen met een WAO-uitkering wordt niet als een prioriteit gezien, hetgeen in de praktijk betekent dat deze populatie (vrijwel) geen aandacht krijgt.

Gedurende de jaren ' 80 ontstaat aandacht voor het belang van de ontwikkeling van reïntegratie activiteiten, teneinde te voorkomen dat mensen tot aan hun pensioengerechtigde leeftijd in een uitkeringssituatie blijven hangen. Deze aandacht wordt in 1986 vertaald in de WAGW, die daarmee de eerste wettelijke maatregel vormt, gericht op de reïntegratie van mensen met een WAO-uitkering. Tegelijk met deze wetswijziging wordt de primaire verantwoordelijkheid voor de bemiddeling van mensen met een WAO-uitkering overgeheveld naar de Gemeenschappelijke Medische Dienst (GMD). Bij de GMD is echter sprake van een structurele onderbezetting; de reìntegratie van mensen met een WAO-uitkering wordt door deze dienst niet beschouwd als een hoofdtaak. De verplaatsing van de verantwoordelijkheid leidt derhalve onvoldoende tot een vermeerdering van de arbeidstoeleidingsactiviteiten. Volgens de Parlementaire Enquête commissie wordt in de periode 1982 - 1991 door de uitvoeringsorganisaties niet effectief gestuurd op reïntegratie doelstellingen en 
volumebeleid. De wettelijke mogelijkheden hiertoe worden passief of terughoudend toegepast, aldus de commissie.

In de periode na 1991 neemt de belangstelling van de uitvoeringsinstellingen voor de reïntegratie toe. Naast deze toegenomen belangstelling voor reìntegratie worden door middel van wetgeving de financiële verantwoordelijkheden van werkgevers voor de doorbetaling van het loon bij ziekte geregeld (Arbo/TZ/WULBZ). Doel van deze wetgeving is het aanmoedigen van de werkgever om meer aandacht te geven aan preventieve activiteiten en de nadruk op vroegtijdige interventies te vergroten teneinde de instroom in de WAO te verkleinen. Deze wetten omvatten een breed scala aan maatregelen gericht op het bevorderen van vroegtijdige reĩntegratie naar werk. Concreet betreft het instrumenten gericht op de werkgever (incentives en verplichtingen/sancties), instrumenten gericht op de werknemer (incentives en verplichtingen/ sancties), scholingsinstrumenten, regelingen gericht op zelfstandigen en regelingen niet specifiek gericht op arbeidsgehandicapten maar die niettemin de reintegratie kunnen ondersteunen.

Ondanks deze reïntegratie stimulerende wetgeving, blijken de reïntegratie instrumenten zelf nauwelijks behulpzaam te zijn bij het aan het werk helpen van mensen die als gevolg van de herbeoordeling hun uitkering kwijtraken (Nool, Spijkerboer \& van Breukelen, 1996). Uit een onderzoek van Donker. Hecke, Meus, Mullenders, Nool \& Wijnands (1996) blijkt dat de oorzaak van de beperkte effectiviteit van de reĩntegratie instrumenten vooral ligt in het geringe gebruik ervan. Dit wordt bevestigd door een onderzoek van Wevers (1997) naar de inzet en effectiviteit van het genoemde instrumentarium, waarbij wordt geconstateerd dat met name een onderbenutting bestaat van de positieve prikkels zoals scholing of werkgeversvoorzieningen (Wevers, 1997). Naast het geringe gebruik blijkt het bij wet geregeld aanbod van reïntegratieprogramma's gering (Selander, Marnetoft, Bergroth \& Ekholm, 1998) en worden verantwoordelijkheden met betrekking tot de reìntegratie van personen met beperkingen afgeschoven, waardoor onduidelijkheid ontstaat over wie waarvoor verantwoordelijk is (Ernste, Wijnands, Schooten \& Baas, 1995). Tevens zorgen de bestaande wettelijke structuren vaak voor een onnodig lange wachttijd en moeten vaak te lange administratieve procedures worden doorlopen, alvorens personen met een arbeidsongeschiktheidsuitkering de mogelijkheid krijgen te starten met een op reïntegratie gericht programma (Bruggeman, 1991; Van Elderen, Simon, Van der Toorn \& Maes, 1995; Emste et al., 1995; Selander et al., 1998). Uit een overzichtsstudie van Mul, De Winter, Nijboer \& Haan (1995) naar methoden voor de reïntegratie van gedeeltelijk arbeidsgeschikten, blijkt dat wettelijke voorschriften, financiêle prikkels en compensaties voor de werkgever weinig invloed hebben op de 
kans op reìntegratie van personen met een arbeidsongeschiktheidsuitkering. Korte en duidelijk vastgestelde lijnen tussen instellingen, hebben een positieve invloed op de kans op reīntegratie van personen met beperkingen (Mul et al., 1995). Tevens melden Gründemann en Nijboer (1998) naar aanleiding van een overzichtstudie dat niet zo zeer de veronderstelde economische motieven (incentives voor de werkgever en/of de werknemer) daarbij van belang zijn, maar dat gezondheidsaspecten en de attitude met betrekking tot het eigen functioneren en de eigen mogelijkheden een veel grotere impact hebben op succesvolle reïntegratie.

De invoering van de wet REA is tot op heden de laatste wettelijke poging om het reïntegratie instrumentarium aan te passen. Met de invoering van de wet REA wordt, naast het wegnemen van knelpunten in de bestaande wet- en regelgeving, het reïntegratic instrumentarium makkelijker bereikbaar, doordat onder meer de administratieve afhandeling is vereenvoudigd en de verantwoordelijkheid voor de reïntegratie komt te liggen bij de persoon of organisatie waarmee de arbeidsgehandicapte een financiële relatie onderhoudt. Uit recentelijk verricht onderzoek naar de effectiviteit van de wet REA, kan worden gesteld dat de wet objectief beschouwd voldoende instrumenten en stimulantia bevat om arbeidsgehandicapten een plaats op de arbeidsmarkt te geven of te behouden, maar dat deze nieuwe wetgeving op het terrein van de reìntegratie nauwelijks invloed heeft op het aantal arbeidsgehandicapten dat weer aan het arbeidsproces deelneemt (Van der Giezen \& Jehoel-Gijsbers, 1999). Redenen hiervoor betreffen de nog onveranderde negatieve houding van het merendeel van de werkgevers ten aanzien van de aanname van arbeidsgehandicapten en de traagheid van afhandeling van de uitvoeringsinstanties. Daarnaast draagt het niet loslaten van de centrale sturing eveneens hieraan bij (Nyfer, 1998).

Geconcludeerd kan worden dat de genomen beleidsmaatregelen binnen de tot nu toe ingevoerde wetgeving juridisch en financieel en dus met name op het systeem zijn gericht. De genomen maatregelen blijken niet in staat om voldoende het gedrag van werkgevers en werknemers met betrekking tot het proces van reīntegratie te beïnvloeden. Wellicht draagt een nadere beschouwing van het begrip arbeidsongeschiktheid en de rol, i.c. de positie van de persoon met een arbeidsongeschiktheidsuitkering bij tot een mogelijke verklaring voor de geringe uitstroom uit de WAO. In de hiernavolgende paragraaf 1.4 zal derhalve worden ingegaan op het begrip arbeidsongeschiktheid en de rol, i.c. de positie van de persoon met een arbeidsongeschiktheidsuitkering als het gaat om zijn/haar reīntegratie. 


\subsection{ARBEIDSONGESCHIKTHEID}

"In order to obtain the right to participate in society, an individual must show that they are incapable of participating in society"

(NOG, 1998)

Uitgangspunt van de Wet op de ArbeidsOngeschiktheid is dat voor werknemers die vanwege ziekte of gebrek hun arbeid niet (meer) kunnen verrichten, een collectieve verzekering wordt geconstrueerd, teneinde een grote terugval in inkomsten te voorkomen. Om van deze collectieve verzekering gebruik te kunnen maken, zal de werknemer een keuring moeten ondergaan, waarbij de mate van zijn/haar arbeidsongeschiktheid wordt bepaald. Onder meer op basis van het oordeel van een verzekeringsarts wordt de mate van arbeidsongeschiktheid (de verdiencapaciteit) van de betreffende werknemer vastgesteld. Hierbij vormt in beginsel de door de arts geconstateerde ziekte of de aandoening, het uitgangspunt. Vervolgens wordt bepaald in hoeverre de ziekte of aandoening leidt tot beperkingen en wordt het percentage arbeidsongeschiktheid bepaald op grond van het theoretisch verlies aan inkomen tengevolge van die beperkingen, uitgaande van het inkomen dat de werknemer zou kunnen verdienen met zijn ervaring en mogelijkheden. In die zin staat daarmee het begrip 'arbeidsongeschiktheid' in Nederland los van de mate van beperking, en heeft het in feite weinig te maken met de vraag of een persoon ongeschikt is voor het verrichten van arbeid. De gehanteerde gradaties in de mate van arbeidsongeschiktheid, variërend van $15 \%-85 \%$, geven eveneens geen inzicht in hoeverre een persoon meer of minder tot werken in staat is. Zij geven slechts aan in welke mate sprake is van geschatte inkomensderving. De vreemde, maar niet denkbeeldige situatie doet zich voor dat een persoon die zich zelf als volledig arbeidsongeschikt beschouwt, op basis van de wettelijke regelingen volledig arbeidsgeschikt wordt verklaard. Omgekeerd kan een persoon bij wet volledig arbeidsongeschikt worden verklaard, terwijl de persoon een geheel tegengestelde mening is toegedaan.

\section{Wetstechnische arbeidsongeschiktheid}

In feite is er sprake van een wetstechnische arbeidsongeschiktheid, ongeacht of de 'zieke' persoon deze ervaart als een daadwerkelijke arbeidsongeschiktheid. Aangezien bij het bepalen van de mate van arbeidsongeschiktheid de ziekte of aandoening wordt losgelaten, krijgt het woord 'zieke' in deze een specifieke invulling. Niet de aandoening staat centraal, maar de erkenning van de omgeving dat de zieke persoon (tijdelijk) niet in staat is om gezien de aanwezige beperkingen een voldoende inkomen 
te verwerven en daarom mag worden ontheven van zijn/haar maatschappelijke verplichtingen alsmede de (tijdelijke) aanvaarding van de patiëntenrol door de werknemer. In wezen spreken we hier over drie componenten van ziekte, namelijk de ziekte als de aanwezigheid van een aandoening, het ziek voelen als een algeheel gevoel van onwelzijn en het ziektegedrag als een roep om erkenning van 'de ziekte'. Binnen de medische sociologie worden deze verschillende rollen respectievelijk benoemd als disease, illness en sickness. Arbeidsongeschiktheid als erkenning van 'het ziektegedrag', wordt binnen de sociologie beschreven als sickness, zich hiermee onderscheidend van ziekte als de aanwezigheid van een aandoening (disease), als wel een gevoel van onwelzijn (illness) (Parsons, 1951).

Als het gaat over het bepalen van de mate van arbeidsongeschiktheid worden twee benaderingswijzen onderscheiden, waarbij in het ene geval ziekte als disease en in het andere geval ziekte als illness als uitgangspunt wordt genomen (De Boer, Croon, Van der Toorn \& Sconky-Achilles, 1996). De causale benadering gaat uit van het principe dat slechts de aanwezigheid van een objectieve aandoening de persoon het recht verleent om zich ziek en arbeidsongeschikt te voelen (nadruk op disease). De finale benadering stelt niet de objectieve aandoening centraal, maar hanteert het principe dat de door de persoon ervaren beperkingen voldoende legitimatie bieden aan deze persoon om zich ziek en arbeidsongeschikt te voelen (nadruk op illness). Bij het bepalen van de mate van arbeidsongeschiktheid wordt de causale benadering als uitgangspunt genomen. Met name personen met ziektes of aandoeningen die niet of nog niet objectief zijn vast te stellen, zoals onder meer ME, zullen bij een causale benadering onder bepaalde condities geen arbeidsongeschiktheidsstatus verkrijgen. Door onder meer jurisprudentie, waarbij de finale benadering als uitgangspunt wordt genomen, kan een dergelijke status toch worden verkregen (De Bont, Meus \& Hazelaar, 1998).

Het verkrijgen van de status van arbeidsongeschikte is in feite een afsluiting van een langer durend medisch proces, waarbij uiteindelijk een formele, medisch-juridische erkenning van de aanwezige problematiek heeft plaatsgevonden. Op basis van een rechtstreeks en objectief medisch vast te stellen gevolg van ziekte of gebrek wordt de arbeidsongeschiktheid vastgesteld, waardoor er een rechtstreeks verband bestaat tussen de aandoening en de arbeidsongeschiktheid. Binnen de causale benadering wordt door middel van het objectiveren getracht om de discretionaire ruimte te beperken. In die zin is de werknemer in casu, behalve als object van keuring, niet bij de besluitvorming hieromtrent betrokken. Daarmee wordt de eigen verantwoordelijkheid van de persoon ten opzichte van de besluitvorming over zijn arbeidsongeschiktheid weggenomen. 
De arbeidsongeschikt verklaarde persoon draagt vervolgens wel een eigen verantwoordelijkheid wanneer het gaat om het ondernemen van activiteiten die moeten leiden tot een afname dan wel herstel van zijn arbeidsongeschiktheid, waarbij de overheid overigens wel weer een toetsende functie heeft.

Het benadrukken vanuit het beleid van de overheid van de eigen verantwoordelijkheid van de werknemer wordt gevoed vanuit het medisch model, waarbij uitgangspunt is dat het 'ziek zijn' van een persoon binnen diens eigen verantwoordelijkheid valt. Het uitgangsprincipe van het medisch model is het bestaan van een causale relatie tussen de aanwezige stoornis van de betreffende persoon en de problemen die de persoon door deze stoornis ervaart. Hierbij wordt verondersteld dat de mogelijkheden en problemen, de maatschappelijke positie en de status van de persoon met beperkingen een regelrecht en onvermijdelijk gevolg zijn van de fysieke, intellectuele of psychische beperkingen. Het arbeidsongeschikt zijn is in feite een lange termijn vorm van zickte en geldt derhalve als een specifiek individueel probleem. Zowel de problemen als oplossingen liggen in de wijze waarop het individu omgaat met zijn functiebeperkingen (French, 1994).

Een persoon die arbeidsongeschikt is vanwege zijn beperkingen wordt echter binnen het medisch denkmodel gezien als iemand die slechts door het opvolgen van adviezen van een professional kan herstellen. De deskundigheid van de professional staat centraal; door het ondernemen van eigen activiteiten - buiten de professional om - zal de arbeidsongeschikte persoon 'niet kunnen herstellen', c.q. de sickness-rol niet kunnen verlaten en in die zin zijn arbeidsongeschiktheid niet kunnen veranderen in arbeidsgeschiktheid. Wanneer dit herstel, c.q. de arbeidsgeschiktheid niet optreedt, is dit binnen het medisch model een gevolg van het niet op een adequate wijze opvolgen van de adviezen. Daarmee ligt de verantwoordelijkheid voor 'herstel' bij de arbeidsongeschikte en niet bij de professional.

Het medisch model staat de laatste jaren steeds meer ter discussie, in die zin dat de verantwoordelijkheid van de omgeving in dit model volledig buiten beschouwing wordt gelaten. De discussies hebben geleid tot nieuwe modellen, waarbij de omgeving van de persoon met beperkingen wordt gezien als beïnvloedende factor wanneer het gaat over de kans op reïntegratie van personen die arbeidsongeschikt zijn verklaard. Binnen deze modellen wordt integratie gezien als een sociale constructie. Met andere woorden, de kans op integratie wordt beïnvloed door zowel interne (bij de persoon gelegen) factoren als door externe (buiten de persoon gelegen) factoren. Het medisch model, kritiekpunten op dit model alsmede de sociale constructie gedachte zullen worden beschreven in de hiernavolgende paragraaf 1.5. De beschrijving hiervan dient 
enerzijds om de resultaten van het in dit proefschrift gepresenteerd onderzoek te kunnen plaatsen, en anderzijds om de hedendaagse situatie in Nederland met betrekking tot arbeidsongeschiktheid en reïntegratie te relateren aan de hierna beschreven gedachtegangen (zie hiervoor paragraaf 7.4: beschouwing) en de consequenties daarvan.

\subsection{MEDISCH MODEL versus SOCIALE CONSTRUCTIE GEDACHTE}

\subsubsection{Medisch model}

"We are viewed trough spectacles that only focus on our inabilities, and which suffer an automatic blindness - a sort of medicalised social reflex - regarding our abilities"

(Brisender, 1986)

Aan het einde van de negentiende eeuw, tijdens de industriele ontwikkeling worden de ideologische en materiele voorwaarden geschapen, die ervoor zorgen dat een ziekte of aandoening wordt gezien als een individueel medisch probleem, waarbij in eerste instantic de professional en in een later stadium de maatschappij een verantwoordelijkheid draagt om het individuele probleem op te lossen (Oliver, 1990; Albrecht, 1992).

Het uitgangsprincipe van het medisch model vormt de causale relatie tussen de aanwezige stoornis van de betreffende persoon en de problemen die de persoon door/met deze stoornis ervaart. De problemen die de persoon ervaart zijn een onlosmakelijk gevolg van de aanwezige stoornis en kunnen in die zin niet worden gezocht in een andere omgeving dan de intrinsieke omgeving. Zola (1982) merkt op dat binnen het medisch model mensen met beperkingen worden gereduceerd tot net iets meer dan een medisch label, hun toekomst wordt gedefinieerd in een medische diagnose.

Volgens het medisch model zijn personen met chronische ziekten of functiebeperkingen, ziek en derhalve patiēnt. Een interventie zal zich richten op het verbeteren of instandhouden van de mogelijkheden van de persoon, waarbij de (para)medicus als de expert, de regie in handen heeft. (Para)Medici hebben een formele bevoegdheid als het gaat over de zeggenschap over personen met beperkingen. Met andere woorden, 'de patiënt' moet de 'professional' gehoorzamen als hij/zij 'beter' wil worden. Door het innemen van de patiëntenrol wordt de 'zieke' persoon vrijgesteld van sociale verantwoordelijkheden (Parsons, 1951). Wanneer er geen 
sociale verantwoordelijkheden gelden voor deze persoon, heeft deze persoon voor diens 'goodwill' ook geen sociale (burger) rechten en wordt hem/haar ook niet het recht gegeven om onafhankelijke besluiten te nemen met betrekking tot herstel en reintegratie. Feit is echter dat de persoon met beperkingen nooit 'beter' wordt en derhalve ook nooit het recht heeft onafhankelijke besluiten te nemen. De professional zal altijd een rol spelen bij de besluiten rondom datgene wat de 'patiēnt' wel of niet moet of kan doen (Pfeiffer, 1999). Zowel voor wat betreft het bepalen van de mate van arbeidsongeschiktheid, het opstellen van reïntegratieplannen en het bepalen van benodigde voorzieningen, wordt de verantwoordelijkheid gelegd bij de professionals, de verzorgers van de personen met beperkingen. In alle gevallen zal hierbij direct dan wel indirect het beslissingrecht in handen van een professional liggen. Ook of iemand een reĭntegratietraject wordt aangeboden, scholing mag volgen, wordt niet door de persoon zelf bepaald, maar door de verantwoordelijke 'professional', Dit verlies van onafhankelijkheid heeft zijn weerslag op verschillende niveau's, namelijk op (1) individueel niveau in termen van zelfwaardering en daarmee op psychologisch welbevinden en kwaliteit van leven, (2) op economisch niveau in termen van arbeidskansen, vervroegde uittreding uit de arbeidsmarkt en inkomensachteruitgang. (3) op sociaal niveau in termen van stigmatisering en marginalisering en (4) op politiek niveau in termen van rechten, kansen en discriminatie (Gignac \& Cott, 1990).

Bovenstaande richt zich voornamelijk op de binnen het medisch model bestaande patiënt - professional relatie. Daarnaast heeft het medisch model ook implicaties voor de maatschappelijke positie van de persoon met beperkingen. De persoon met beperkingen behoort daardoor namelijk tot een minderheidsgroepering in een omgeving van voornamelijk valide 'gezonde' mensen en woont in een voor nietbeperkte personen ingerichte samenleving (Dear, Wilton, Lord Gaber \& Takahashi, 1997). Voor de persoon met beperkingen gelden derhalve de normen van de valide 'gezonde' omgeving. De persoon met beperkingen zal zoveel mogelijk streven te voldoen aan de normen van deze valide 'gezonde' wereld. De persoon heeft behoefte om 'normaal' te zijn, normalisering betekent in dit geval integratic. Vanuit het gezichtspunt van het medisch model kan deze persoon echter 'niet normaal' zijn. In wezen is hier sprake van een paradoxale situatie; immers een persoon met beperkingen is in de ogen van de samenleving niet normaal en kan in die zin dus niet participeren in sociale activiteiten. Echter door zijn/haar streven naar 'het normale', overtreedt deze persoon de normen die behoren tot de 'sickrole' doordat ze zich niet terugtrekken uit sociale activiteiten (Murphy, Scheer, Murphy \& Mack, 1988). Naarmate de beperking minder zichtbaar is zou het voor de hand liggen te veronderstellen dat de maatschappelijke acceptatie groter is, en daarmee de integratie. Echter, in de praktijk is 
dat omgekeerd: de geringere zichtbaarheid zorgt in werkelijkheid voor een geringere herkenning en dus geringere acceptatie van 'het niet normale'.

De kans op reïntegratie zal, op basis van het medisch model, het grootst zijn wanneer de arbeidsongeschikte zich zoveel mogelijk aanpast aan en functioneert als de 'gemiddelde gezonde' burger.

\subsubsection{De sociale constructie van een handicap}

"In our view, it is society which disables physically impaired people. Disability is something imposed on top of our impairment by the way we are unnecessarily isolated and excluded from full participation in society"

(UPIAS, 1975)

De causale benadering van het medisch model wordt van meerdere kanten bekritiseerd. Psychologen bekritiseren het medisch model, omdat het model niet onderkent in welke mate beperkingen in de uitvoering van activiteiten worden veroorzaakt door de psychologische ervaringen van de aanwezige beperkingen (Johnstone, 1966). Eveneens wordt aangegeven dat door het focussen op de defecten in intellectueel of lichamelijk opzicht, de tekortkomingen in de omgeving niet worden onderkend (Abberley, 1987; Abberley, 1991; Hevey, 1992). Anderen geven aan dat problemen met integratie van mensen met beperkingen eerder wordt veroorzaakt door extrinsieke factoren als attitudes van anderen en de frustratie vanwege discriminatie, dan door intrinsieke factoren in de zin van de ziekte of aandoening (Partridge, 1990; Morris, 1991; Finger, 1991: Keith, 1996). Finkelstein (1980) geeft deze visie weer in een model (figuur 1.1). Hij gaat hierbij uit van het extreme standpunt dat het hebben van een handicap door niets anders dan door de omgeving wordt bepaald.

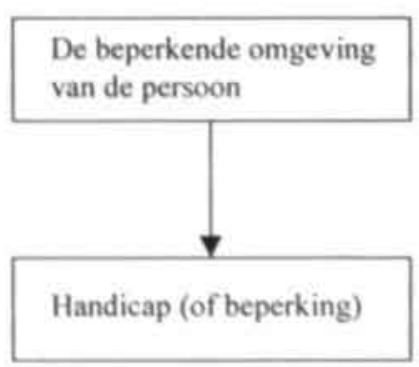

Figuur 1.1 Oorzakelijke weergave van het ontstaan van een handicap, Finkelstein (1980) 
Met dit model willen Finkelstein en anderen (UPIAS, 1976) een tegenreactie geven op het bestaande medische model dat naar hun idee tekortschiet in zijn eenzijdige benadering. Wanneer een persoon met een ziekte of aandoening deze als beperkend ervaart in zijn/haar functioneren dan wel als een handicap wordt dit, volgens het model van Finkelstein, direct veroorzaakt door omgevingsgebonden factoren, zoals onder meer attitudes van anderen, economische omstandigheden en sociaal-culturele factoren en niet door de aanwezige ziekte of aandoening. Wanneer de omgeving zich aanpast zowel de sociale, de maatschappelijke als de politieke omgeving - ondervindt de persoon met beperkingen geen belemmeringen meer. Wanneer de gestructureerde omgeving in gebreke blijft om zich aan te passen aan de behoeften en ambities van mensen met hun functiebeperking, zal deze beperking als een handicap worden ervaren. Hiermee worden de oorzaak en de daarbij behorende oplossingen niet meer bij het individu gelegd, maar bij de omgeving die zich moet aanpassen aan de persoon.

Ook anderen wijzen erop dat er weliswaar een medische kant zit aan het hebben van een beperking, maar dat het grootste deel van de beperking wordt veroorzaakt doordat de omgeving dusdanig is gecreeterd, dat mensen met beperkingen grote nadelen hiervan ondervinden (Wright, 1983; Meyerson, 1988; Amundson, 1992; Bickenbach \& Barnes, 1994; Imrie, 1997): de omgeving schept daarmee de handicap.

Oliver's (1990a en b) kritiek op het medisch model richt zich met name op het gegeven dat niet de personen met beperkingen wordt geconsulteerd over hun ervaringen ten aanzien van het leven met een beperking, maar dat de (para)medici hierover worden geconsulteerd, terwijl deze groep zich nauwelijks inspant om aan de persoon met beperkingen zelf te vragen, hoe deze het ervaart om te leven met een beperking.

Marks (1997) merkt op dat teveel aandacht wordt besteed aan therapie, correctieve operaties en protheses om daarmee mensen met beperkingen 'normaal' te maken, echter vrijwel geen aandacht wordt besteed aan de eigen prioriteiten van mensen met beperkingen. Door Marks wordt tevens geconstateerd dat de onvoorwaardelijke acceptatie van de naar eigen inzichten en principes handelende professional, door mensen met beperkingen niet meer als vanzelfsprekend wordt gezien. Hierdoor ontstaat een strijd ten aanzien van de rol invulling van de cliënt en de professional, waarbij het niet meer gaat over inhoud, maar over bewaking van eigen terrein en macht.

De kritiek leidt tot een aangepaste visie over mensen met beperkingen en tot een andere benadering van factoren die van invloed zijn op integratie: de sociale constructiegedachte. Hierbij wordt de omgeving als beìnvloedende factor meegenomen. 
Binnen de sociale constructie gedachte worden problemen ten aanzien van de integratie van mensen met beperkingen niet zozeer als een individueel probleem gezien, maar meer als een inadequate manier waarop de maatschappij omgaat met personen met beperkingen (Hahn, 1985). De problemen die de persoon met beperkingen ervaart om deel te nemen aan een normaal sociaal leven, worden niet veroorzaakt door de aanwezige ziekte of aandoening alléén, maar zijn ook een gevolg van de fysieke en sociale barrières binnen de maatschappij (Barnes, 1994; Bickenbach, Chatterji, Badley \& Üstün, 1999). Abberley (1987), Albrecht (1992), Hahn (1988) en Oliver (1990a en b) zijn eenzelfde mening toegedaan, zij constateren dat het hebben van een beperking een gevolg is van maatschappelijke attitudes, instituties en maatschappelijke structuren. Gartner en Joe (1987) zoeken de oorzaak slechts op één niveau, zij stellen dat de barrières die mensen met beperkingen ervaren in educatie, werk, behuizing en vervoer niet het gevolg zijn van hun medische conditie, maar het gevolg van de negatieve attitudes van anderen en stereotypering ten aanzien van hun mogelijkheden en behoeften. Mensen met beperkingen worden gezien als bijzonder behoefte-afhankelijk, echter ze worden in feite zo afhankelijk gemaakt vanwege het feit dat de verdeling van middelen op een zodanige wijze plaatsvindt, dat dit discriminerend werkt ten aanzien van de groep mensen met beperkingen (Campbell \& Oliver, 1996). We spreken hier van een sociaal geconstrueerd behoefteconcept. Dat wil zeggen dat hetgeen wordt gezien als een behoefte, grotendeels afhankelijk is van de sociale organisatic. Indien de bron van de door mensen met beperkingen ondervonden problemen moet worden gezocht in een falen van de sociale organisatie, dan kan vervolgens de oplossing worden gezocht op politiek niveau, in de zin van een veranderde attitude, veranderde wetgeving en veranderde beleidsvoering (Hahn, 1986). En daarmee verschuift het accent van de individuele medische benadering naar de sociale, culturele, economische en politieke omgeving.

Een dergelijke verschuiving is belangrijk vanuit het reïntegratieperspectief. Door integratie te zien als afhankelijk van de interactie tussen de persoon met een aandoening en zijn/haar omgeving, opent dit perspectieven voor de vergroting van de kansen op integratic. Veranderingen in de omgeving kunnen leiden tot integratie, terwijl de aandoening toch blijft bestaan.

De interactie tussen ziekte, stoornis, beperking en mogelijk interveniërende factoren, namelijk de fysieke omgeving, de sociale situatie en middelen wordt door Badley (1987) (figuur 1.2) weergegeven als zijnde de oorzaak van de handicap die iemand ervaart. 


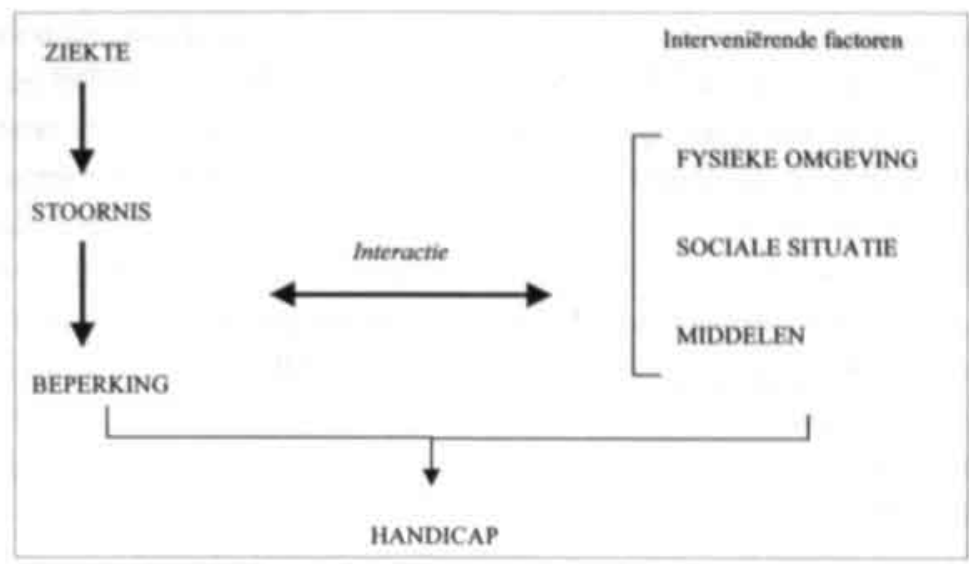

Figuur 1.2 Oorzakelijke weergave van het ontstaan van een handicap, Badley (1987)

Handicap is in deze een breed begrip, en kan in het kader van dit proefschrift worden uitgelegd als het gebrek aan de mate van integratie van deze persoon in de sociale- en werkomgeving. De fysieke omgeving betreft de omgeving waarin de persoon met beperkingen verkeert, en heeft met name betrekking op ruimtelijke barrières. De sociale situatie van de persoon met beperkingen wordt beïnvloed door zowel de attitudes van de directe sociale omgeving als de attitude van de maatschappij ten opzichte van mensen met beperkingen. De middelen die in het model (figuur 1.2) worden genoemd, hebben betrekking op datgene wat de persoon met beperkingen tot beschikking staat om op een adequate wijze om te kunnen gaan met deze beperkingen zoals persoonlijke kwaliteiten, beschikbare hulpmiddelen, ondersteuning van de (directe) sociale omgeving, het inkomen en andere materiele bezittingen.

Fougeyrollas \& Saint-Michel (1991) presenteren een soortgelijk model, waarbij de 'handicap' is vervangen door 'leefstijl' (figuur 1.3). In dit model vormt de weergegeven interactie tussen stoornissen, beperkingen (en mogelijkheden) en omgevingsfactoren (voorgesteld als barrières) de basis voor het handicap proces. Een opvallend verschil met het model van Badley is de toevoeging van de mogelijkheden van de persoon. Daar waar Badley alleen uitgaat van de stoornissen, ervaren beperkingen en de hieruit voortvloeiende mate van handicap die een persoon ervaart, geven Fougeyrollas \& Saint-Michel duidelijk aan dat de persoonlijke potentie eveneens van invloed is op dit proces. 


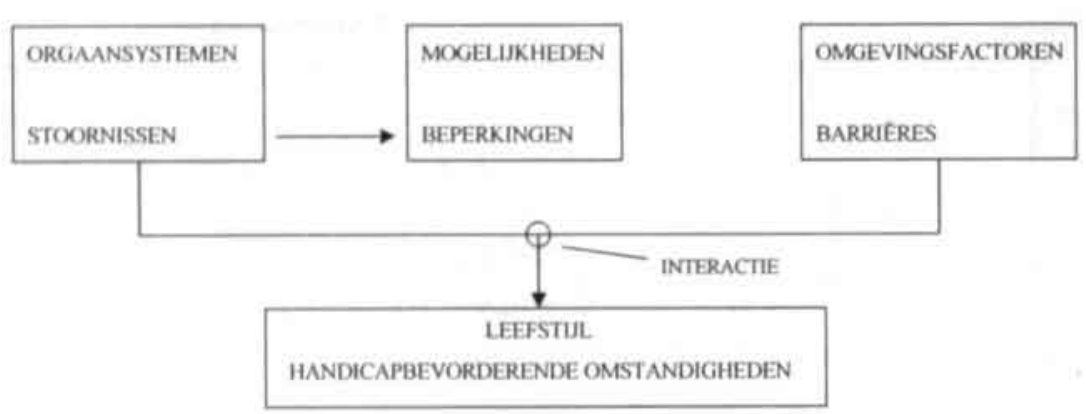

Figuur 1.3 Oorzakelijke weergave van het ontstaan van een handicap, Fougeyrollas \& Saint-Michel (1991)

De beperkende factor in het model van Fougeyrollas \& Saint-Michel is dat in dit model wordt uitgegaan van de intrinsieke mogelijkheden en geen rekening wordt gehouden met de feitelijke mogelijkheden van een persoon. Intrinsieke mogelijkheden worden gedefinieerd als het kunnen verrichten van bepaalde activiteiten zonder enige persoonlijke assistentie of materiele ondersteuning. De feitelijke mogelijkheden worden gedefinieerd als de mogelijkheid om persoonlijke of materiele assistentie te krijgen. Bijvoorbeeld, hulp in de ochtend bij het aankleden (knopen dichtmaken), zodat iemand keurig gekleed kan gaan, kan onder meer bijdragen aan het behouden van een hoge arbeidsmarktpositie (Verbrugge \& Jette, 1994). Volgens het model van Fougeyrollas \& Saint-Michel bestaat er geen relatie tussen de ervaren beperking en de omgevingsfactoren, beide zijn onafhankelijk van elkaar van invloed op de uitkomstvariabele 'leefstijl'. De beperking wordt in het model weergegeven als een persoonlijk kenmerk. De sociale constructic benadering geeft een goed inzicht in de maatschappelijke constructen van een handicap, bijvoorbeeld zoals deze plaats heeft in de arbeidsongeschiktheidswetgeving, maar lijkt minder bruikbaar bij het ontwikkelen van op het individu toegesneden reïntegratie activiteiten.

\subsubsection{Naar een integraal kader}

$\mathrm{Bij}$ de arbeidsintegratie van personen met een beperking moet zowel worden gekeken naar de beperkingen die iemand heeft in de werksituatie als naar de maatschappelijke wijze waarop wordt omgegaan met een beperking. De arbeidsongeschiktheidswetgeving creěert een categorie van arbeidsgehandicapten, stigmatiseert hen daarmee en schept ook specificke voorzieningen; arbeidsintegratie vraagt om specifieke matching tussen mogelijkheden en arbeidsgebonden eisen. Vandaar dan ook dat Haber (1990) en Nagi (1991) aangeven dat het hebben van een beperking niet kan worden gezien als een persoonlijk kenmerk. zoals bijvoorbeeld leeftijd of beroep. maar als een relatie tussen 
de persoon en zijn/haar omgeving. Een beperking treedt op wanneer er een hiaat zit tussen de benodigde capaciteiten voor de betreffende activiteit en de persoonlijke (intrinsieke en extrinsieke) mogelijkheden. De beperking kan volgens hen aan beide zijden worden opgeheven, door het vergroten van iemands mogelijkheden of door de benodigde capaciteiten voor de activiteit te verminderen. Verbrugge \& Jette (1994) geven deze zienswijze weer in een model (figuur 1.4). Hierbij komt de beperking deels voort uit de aanwezige ziekte of aandoening, deels wordt beïnvloed door intra - en extraïndividuele factoren die de mogelijkheden van een persoon bepalen en deels wordt beînvloed door intra- en extraîndividuele factoren die de behoefte i.e. de vraag bepalen.

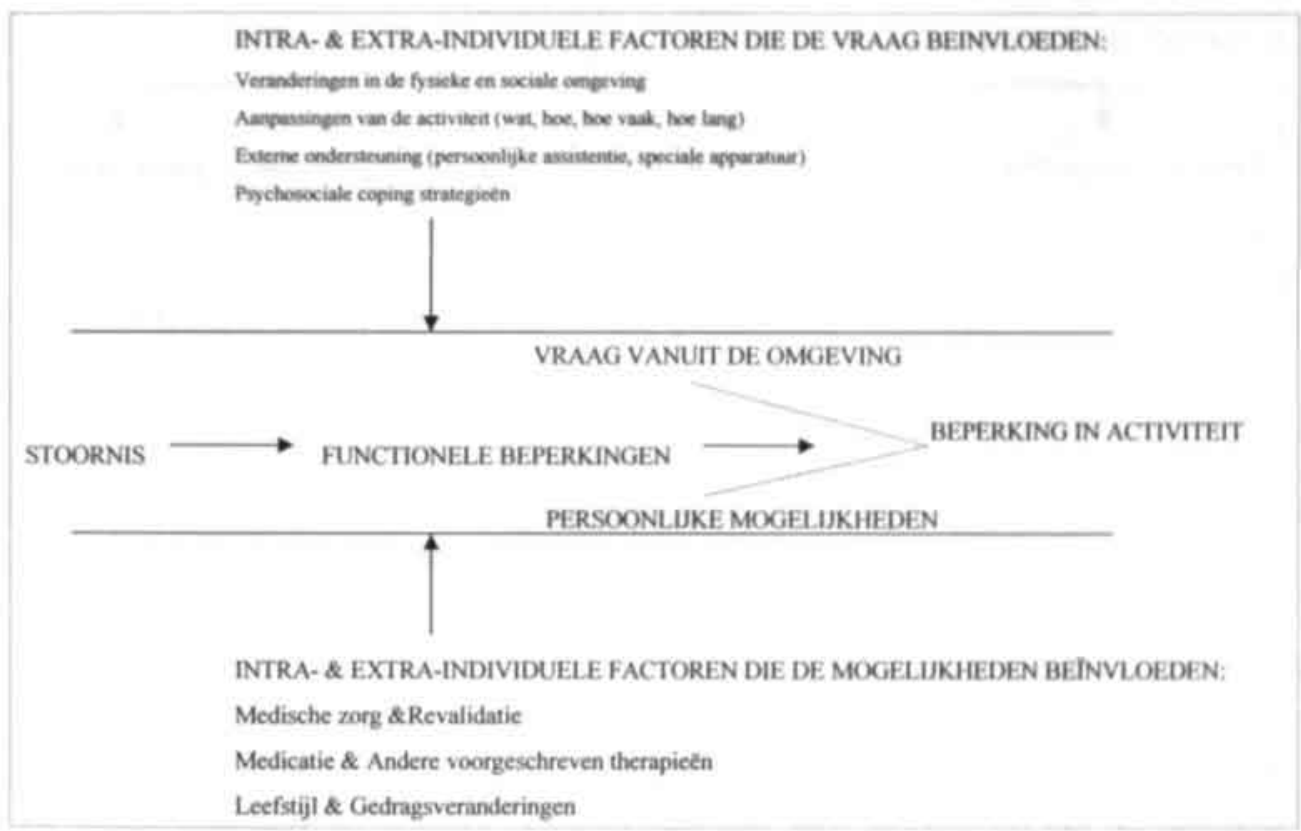

Figuur 1.4 Beperking in activiteit, weergegeven als een hiaat tussen mogelijkheid en behoefte, Verbrugge en Jette (1994)

In dit model geven Verbrugge \& Jette (1994) concrete handgrepen ten aanzien van zowel het bepalen van de mate van participatie, als het concreet kunnen aanpakken van de mogelijkheden teneinde de participatie van een persoon te verbeteren. Wat het model echter niet expliciet weergeeft, is de invloed van persoonsgebonden factoren als bijvoorbeeld motivatie waarvan uit eerdere studies bekend is dat deze hun invloed uitoefenen op de mate waarin iemand beperkingen op individueel of maatschappelijk niveau ervaart (Rosenthal, 1974: Griffiths, 1977; Clark. Anderston \& Skinner, 1981; 
Anthony \& Jansen, 1984; Berghoeff, Martijn \& Merens-Riedstra, 1987; Fitzgerald, Becker \& Celentano, 1989; Michon \& Van Weeghel, 1990, zie ook paragraaf 2.3), alsmede de wisselwerking die in de praktijk bestaat tussen factoren die de mogelijkheid beïnvloeden en factoren die de behoefte beïnvloeden. In die zin geeft het model dat ten grondslag ligt aan de definiëring binnen de ICIDH-2, die wordt gehanteerd door de World Health Organisation (ICIDH-2, 1999), een meer realistische weergave van de werkelijkheid (zie figuur 1.5).

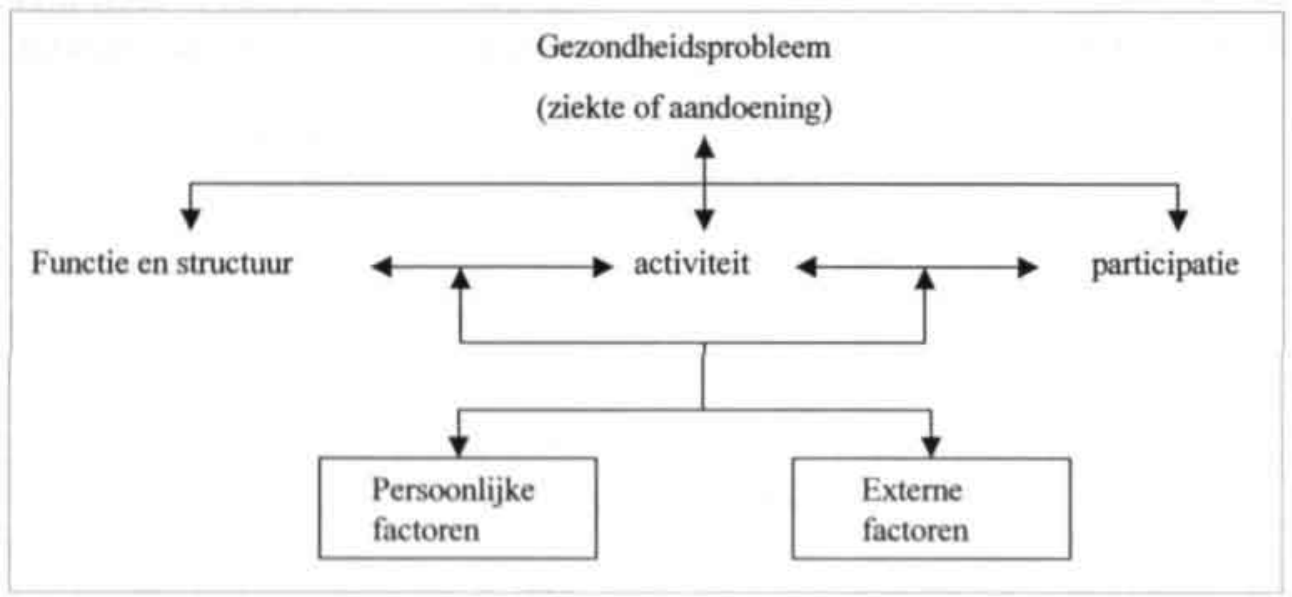

Figuur 1.5 Gangbare opvatting over de wisselwerking tussen de dimensies van het ICIDH-2 voorstel, (ICIDH-2,1999)

In dit model wordt het menselijk functioneren gezien in het licht van een complexe relatie tussen een aandoening enerzijds, en de externe en de persoonlijke factoren anderzijds. De wisselwerking tussen al deze factoren heeft een dynamisch karakter: interventies op het niveau van het ene element kunnen in beginsel leiden tot veranderingen in andere gerelateerde elementen. De interacties zijn specifiek en staan niet in een voorspelbare één op één relatie tot elkaar. Het model betreft een hulpmiddel om de dimensies die op elkaar van invloed te zijn, in kaart te brengen. Het betekent niet dat alle factoren in alle gevallen even relevant zijn, en eveneens niet dat een beperkende factor in een van de dimensies automatisch beperkingen oplevert in een andere dimensie.

De tekortkomingen die in eerdere modellen zijn te herkennen, zijn hiermee grotendeels weggenomen, in die zin dat binnen het in figuur 1.5 gepresenteerde model wordt weergegeven dat de mate van participatie afhankelijk kan zijn van biologische, psychische en sociale factoren, die elkaar weer wederzijds kunnen beïnvloeden. De 
aanwezigheid van een aandoening of ziekte wordt niet ontkend, echter de beperkingen die een persoon daardoor ervaart kunnen afhangen van de functie en structuur, externe factoren zoals attitudes van anderen, persoonlijke factoren, maar ook van de mate waarin de persoon participeert in zijn/haar sociale omgeving. Het model bouwt daarmee voort op zowel aspecten van het medisch model als op aspecten van de sociale constructie gedachte, en kan derhalve worden gezien als een integratie van beide modellen.

Vanuit dit integrale kader geldt dat, indien de aandacht uitgaat naar de uitstroom uit de WAO, i.e. de reĩntegratie naar arbeid van mensen die vanwege een ziekte of aandoening arbeidsongeschikt zijn verklaard, de mate van participatie in de betekenis van het vinden en behouden van een baan met name zal worden beìnvloed door de mate waarin een persoon met een specifieke ziekte of aandoening bepaalde activiteiten kan uitvoeren, alsmede persoonlijke en externe factoren en de wisselwerking tussen de genoemde dimensies. Met andere woorden, het proces van arbeidsreīntegratie wordt beïnvloed door persoonsgerelateerde factoren alsmede factoren uit de sociale en maatschappelijke omgeving, waaronder bedrijfsgebonden factoren.

In het hiernavolgende hoofdstuk 2 zullen de uit eerder onderzoek bekende persoonsgerelateerde factoren (inclusief de invloed van de ziekte of aandoening), factoren uit de sociale en maatschappelijke omgeving én de bedrijfsgebonden factoren worden gepresenteerd, alsmede de mate waarin deze factoren zijn te beïnvloeden. 



\section{FACTOREN VAN INVLOED OP REÏNTEGRATIE}

Zoals aangegeven in de laatste paragraaf van het vorige hoofdstuk wordt het proces van reïntegratie voornamelijk beĭnvloed door externe factoren, bestaande uit omgevingsgebonden factoren en bedrijfsgebonden factoren én persoonsgebonden factoren. De invloed van de persoonsgebonden factoren, omgevingsgebonden factoren en bedrijfsgebonden factoren op succesvolle reïntegratie zullen respectievelijk in de paragrafen 2.1, 2.2 en 2.3 aan de orde komen. In paragraaf 2.4 wordt weergegeven in hoeverre deze persoonsgebonden factoren, omgevingsgebonden factoren en bedrijfsgebonden factoren te beĩnvloeden zijn. In paragraaf 2.5 zal de onderzocksvraagstelling worden gespecificeerd en wordt een model gepresenteerd op basis waarvan het in dit proefschrift beschreven onderzoek heeft plaatsgevonden. Tot slot zal in paragraaf 2.6 een aantal vraagstellingen worden geformuleerd op basis waarvan de onderzoeksvraagstelling zal worden beantwoord.

\subsection{PERSOONSGEBONDEN FACTOREN}

Verschillende persoonsgebonden factoren blijken samen te hangen met de kans op succesvolle reïntegratie. Binnen deze persoonsgebonden factoren kan een onderscheid worden gemaakt tussen sociaal-demografische factoren, gezondheidsfactoren en factoren die zijn gerelateerd aan (het functioneren van) de persoon zelf. Sociaaldemografische factoren betreffen de leeftijd van de persoon met beperkingen. het geslacht, het opleidingsniveau van de persoon en het (al dan niet aanwezige) arbeidsverleden. Gezondheidsfactoren hebben betrekking op de aanwezigheid van een bepaalde ziekte of aandoening en de beleving hiervan door de persoon. Factoren die zijn gerelateerd aan de persoon zelf, betreffen onder meer de motivatic, persoonlijke attitude, zelfvertrouwen, intelligentieniveau en flexibiliteit.

In het hiernavolgende zullen respectievelijk de sociaal-demografische factoren, de gezondheidsfactoren en de factoren gerelateerd aan de persoon zelf, worden beschreven in relatie tot de kans op succesvolle reìntegratie.

\subsubsection{Sociaal-demografische kenmerken}

De sociaal-demografische kenmerken leeftijd, geslacht, opleiding en arbeidsverleden worden beschreven, voor zover zij van invloed zijn op succesvolle reìntegratie van 
personen met beperkingen. Bovendien zal kort worden ingegaan op het demografische kenmerk woonplaats en de relatie die deze factor heeft met succesvolle reïntegratie.

\section{Leeftijd}

Uit verschillende onderzoeken blijkt dat - ongeacht de ziekte of aandoening - de kans op reïntegratie voor jongeren hoger is dan voor ouderen (Gogstadt, 1968; Spruit, Van de Nieuwe Giessen \& Nes-Achilles, 1986; Bremer \& Corten, 1989; Van der Aa \& Vlaanderen, 1991; Van Beek \& Van Praag, 1992; Mannila, 1995). Daarnaast wordt bij onderzoek naar de kans op reïntegratie voor personen met een specifieke aandoening of ziekte eveneens geconstateerd dat naarmate de leeftijd stijgt, de kans op reïntegratie afneemt. Dit geldt voor personen met een psychische aandoening (Wöhrl, 1990), personen met hersenletsel (Fruhauf, 1994), werknemers met aandoeningen aan het bewegingsapparaat en werknemers met hartklachten (Yelin, 1986; Russel, AbiMansoer \& Wenger, 1986; Gehring, Koenig \& Rana, 1988; Danchin, 1988; Munro, 1990; Mark, Lam, Lee, Clapp-Channing, Williams, Pryor, Califf \& Hlatky, 1992; Ahlgren \& Hammarstrom, 1999).

Deze bevindingen worden ook bevestigd door Straaton, Maisiak, Wrighley, White, Johnson \& Fine (1996). Zij constateren dat een hogere leeftijd onlosmakelijk is verbonden met een kleinere kans op het terugkeren naar de werksituatie. Bij een systematische analyse van follow-up onderzoeken constateren Riipinen, Hurri \& Alaranta (1994) dat leeftijd een essentiële rol speelt bij het al dan niet slagen van een reĭntegratic op de lange termijn, hoe hoger de leeftijd, hoe kleiner de kans op reinntegratie.

Toegespitst op de Nederlandse situatie blijkt een dergelijk verband eveneens te bestaan. In de periode van vlak voor en na de stelselherziening (zie paragraaf 1.2) is sprake van een curvi-lineair verband tussen een stijgende leeftijd en de kans op reïntegratie (Van der Stelt \& Bruinsma, 1989; Kers \& Bruinsma, 1989). Met andere woorden, de kans op werk neemt toe met de leeftijd, tot op een zeker punt, waarna weer een daling van de kans op werk ontstaat. In de beginjaren negentig blijkt er inmiddels een vrijwel negatief lineair verband te bestaan tussen een stijgende leeftijd en de kans op reîntegratie (Kers et al., 1996).

\section{Geslacht}

Uit vrijwel alle publicaties blijkt een verschil in reïntegratiekansen tussen mannen en vrouwen. Nijboer et al. (1993) constateren dat mannen meer kans hebben op werkhervatting, ook na correctie voor diverse relevante factoren als ziekte of aandoening, aantal dienstjaren, opleidingsniveau, deeltijdwerk of het werken in lagere 
functies. Na een intensief reìntegratieprogramma te hebben gevolgd blijken jonge mannen meer succesvol in het verkrijgen van een baan dan jonge vrouwen, ondanks het feit dat de jonge vrouwen hoger zijn opgeleid (Ahlgren \& Hammarstrom, 1999). In een twee-jarige follow up studie naar werkhervatting na arbeidsongeschiktheid vanwege chronische pijn, blijkt het geslacht de meest voorspellende variabele voor het niet vinden van werk: vrouwen blijken minder vaak te reïntegreren dan mannen (Eklund, 1992).

Een aantal onderzoekers heeft naast de constatering dat vrouwen ten opzichte van mannen minder kans maken op reïntegratie, onderzocht welke aspecten hierop van invloed kunnen zijn. Een van de redenen kan zijn dat mannen ten opzichte van vrouwen meer gericht zijn op het (weer) vinden van werk op de reguliere arbeidsmarkt (Hennessey \& Muller, 1995). Volgens Cuelenaere (1997) blijken vrouwen minder gemotiveerd dan mannen om ook bij gezondheidsklachten weer aan het werk te gaan. Daarnaast blijkt uit dit onderzoek dat vrouwen door werkgevers minder worden gewaardeerd. Van Beek \& Van Praag (1992) tonen aan dat vrouwen minder snel worden aangenomen in lagere functies met een hoge fysieke belasting. Vooroordelen ten aanzien van de fysieke belastbaarheid van vrouwen lijken hierbij een doorslaggevende rol te spelen. Ook de zorg van het huishouden en het gezin blijkt een belangrijke belemmering te zijn om (weer) aan het arbeidsproces deel te nemen (Van der Aa \& Vlaanderen, 1991).

\section{Opleiding}

Personen met een arbeidsongeschiktheidsuitkering vanwege een of meerdere beperkingen die een lage opleiding hebben, hebben minder kans op reintegratie in het arbeidsproces dan personen met een arbeidsongeschiktheidsuitkering die een hogere opleiding hebben (Woodyard, 1980; Clark, Anderson \& Skinner, 1981; Lenshoek, van Haselen \& van Dijk, 1988; Smith \& O'Rourke, 1988; Kalbfleisch, Lehmann \& Steinman, 1989; De Koning \& Vuijk, 1989; Van der Stelt \& Bruinsma, 1989; Kers, 1990; Markenson, 1991; Mark et al., 1992; Riipinen et al, 1994; Straaton et al, 1996). In een onderzoek van Mannila (1995) wordt gevonden dat voor mannen met een beperking, een lagere opleiding een negatief effect heeft op reïntegratic. Straaton, Maisiak, Wrighley, White, Johnson \& Fine (1995) constateren dat het opleidingsniveau een van de belangrijkste voorspellers is voor succesvolle reintegratie van mensen met beperkingen. De kans op blijvende succesvolle reìntegratie voor chronisch zieken wordt bevorderd wanneer zij beschikken over een goede opleiding (Van Elderen et al., 1995). Gogstadt (1968) en Mann (1994) onderzochten de kenmerken van personen met beperkingen die na afloop van een reĭntegratieprogramma succesvol 
functioneren op de arbeidsmarkt. Succesvol gereïntegreerde personen blijken een hoger opleidingsniveau te hebben. Bovendien blijkt dat naarmate de economische positie van de gereĭntegreerde werknemer beter is, de kans op blijvende reïntegratie groter is (West, 1996), hetgeen direct gerelateerd is aan het opleidingsniveau. Tevens blijkt dat ook in de beleving van personen met beperkingen die niet werken, het opleidingsniveau een belangrijke factor is (Berghoeff et al., 1987).

\section{Arbeidsverleden}

Het arbeidsverleden van een persoon met een arbeidsongeschiktheidsuitkering vanwege de aanwezige beperkingen, speelt met name een grote rol wanneer het gaat over de kans op werkhervatting bij de oude werkgever. Naarmate een werknemer langer in dienst is, is de kans op werkhervatting bij de oude werkgever groter (Van der Stelt et al., 1996).

De kans op reïntegratie naar een nieuwe werkgever wordt behalve door het arbeidsverleden ook beïnvloed door de duur van de periode dat iemand niet werkt. Personen die voorafgaande aan een reïntegratieprogramma langdurig werkloos zijn geweest, hebben een kleinere kans om te reïntegreren dan personen die korter werkloos zijn (Gogstadt, 1968; Kloosterman, 1987; Taylor, 1989; Muffels, Rietveld \& Vriens, 1990; Latham \& Davis, 1994; Regenold, Sherman \& Fenzel, 1999). Eveneens wordt het verzuimverleden van de te reïntegreren persoon met beperkingen genoemd als een belangrijke factor die de kans op succesvolle reìntegratie kan beïnvloeden. Een verleden met veel verzuim vermindert de kans op werkhervatting (Sandström, 1986; Grosfeld, 1988; Munro, 1990; Van Beek \& Van Praag, 1992).

In een onderzoek naar de Nederlandse situatie vinden Van der Stelt \& Bruinsma (1989) dat werkhervattingen na arbeidsongeschiktheid met name plaatsvinden rond het einde van het eerste jaar ziekte en gedurende het eerste jaar daarna. In het door hen verricht onderzoek wordt tevens gevonden dat een arbeidsongeschiktheidsperiode van langer dan achttien maanden leidt tot een aanzienlijke daling van de kans op werkhervatting. Volgens Kayser (1996) is langdurig verzuim door arbeidsongeschiktheid, onafhankelijk van de diagnose en de werksituatie, een van de beste voorspellers van blijvende arbeidsongeschiktheid.

Uit een overzichtsstudie van Riipinen et al. (1994) blijkt werkloosheid, voorafgaande aan een reìntegratieprogramma geen invloed te hebben op het al dan niet succesvol vinden van een baan, na afloop van het gevolgde reintegratieprogramma. Wel wordt een relatie gevonden tussen de werkloosheidsduur voor de nieuwe aanname en het behoud van een baan op de lange termijn. 


\section{Woongebied}

Mannila (1995) vindt in zijn onderzoek naar factoren die van invloed zijn op het vinden en behouden van werk voor personen met beperkingen dat reîntegratiesucces voor vrouwen met beperkingen sterk gerelateerd is aan de woonplaats. Bovendien constateert hij dat de problemen die personen met beperkingen ervaren, niet aan het individu zijn gerelateerd, maar aan de omgeving waarin de persoon met beperkingen verblijft.

Spruit et al. (1986) en Nijhuis \& Bullinga (1987) vinden een positief verband tussen de kans op reīntegratie en de mate waarin werknemers met beperkingen afkomstig zijn uit verstedelijkte gebieden. Dit positief verband wordt volgens deze auteurs met name veroorzaakt door het grotere banenaanbod in verstedelijkte gebieden.

\subsubsection{Gezondheid}

Wanneer het gaat over gezondheid in relatie tot de kans op reinntegratie, blijken zowel de aard van de gezondheidsklachten (diagnose), de ernst van de aandoening en het verloop van de aandoening van belang te zijn bij werkhervatting.

In het algemeen kan worden gesteld dat mensen met een verminderde gezondheid minder kans hebben om weer aan het werk te komen en te blijven (Verkley. 1988; Van der Aa \& Vlaanderen, 1991; Van Beek \& Van Praag. 1992).

In een groot aantal studies wordt gekeken naar specifieke aandoeningen en de mate waarop deze aandoeningen problemen kunnen opleveren bij het (weer) vinden van werk. Gezien de grote verschillen tussen de methoden van onderzoek die in deze publicaties worden beschreven, is het niet mogelijk de uitkomsten met elkaar te vergelijken om een hiërarchische structuur aan te brengen in de soort aandoening en de kans op reïntegratie. Derhalve zal worden volstaan met het vermelden van de relatie tussen de specifieke ziekte of aandoening en de kans op reĭntegratie. Onder meer wordt gevonden dat personen met psychische beperkingen een geringere kans op succesvolle reïntegratie hebben, dan op grond van leeftijd en opleidingsniveau zou kunnen worden verwacht (Gogstadt, 1968; Cristol, 1970; Noble \& Collignon, 1987; Kaaij, 1992; Kers et al., 1996). Ook personen met klachten aan het bewegingsapparaat en personen met een hart- of vaatziekte ervaren problemen bij het vinden van werk, nadat ze vanwege deze klachten langer dan een jaar arbeidsongeschikt zijn geweest (Kers et al., 1996). Personen met chronische pijnklachten ervaren een verminderde kans op het (weer) vinden van werk bij een nieuwe werkgever (Straaton et al., 1996). Dit geldt tevens voor personen met een traumatisch hersenletsel; met name cognitieve beperkingen, tot uitdrukking komend in traagheid in handelingen en een slechtere concentratie blijken de belangrijkste barrières te vormen voor succesvolle arbeidsintegratie (Parente \& 
Stapleton, 1996). Uit onderzoek naar de arbeidsmarktpositie van mensen met enkele specifieke ziekten van het bewegingsapparaat, zoals bepaalde vormen van spierdystrofie, reuma en de ziekte van Bechterew blijkt dat de meesten van hen niet meer aan het werk komen (Wevers, Nijboer \& Andries, 1993).

Niet alleen de soort aandoening, maar ook de ernst van de aandoening blijkt van grote invloed op de kans op werkhervatting (Smith \& O'Rourke, 1988; Van Sonsbeek \& Verweij, 1991; Kers et al., 1996; Van der Stelt et al., 1996). Hierbij kan de uitgebreidheid van de beperkingen, de aanwezigheid van eventuele complicaties of meervoudige handicaps en het hebben van pijn van invloed zijn (Sandström, 1986; Yelin, 1986; Feuerstein \& Therbarge, 1991; Weiser \& Cedraschi, 1992;). Ook blijkt de mate waarin resterende functionele capaciteiten aanwezig zijn, wezenlijk bij te dragen aan een succesvolle reïntegratie op de arbeidsmarkt (Riipinen et al., 1994).

Naarmate de aandoening een meer wisselend verloop kent, heeft dit een negatieve invloed op de kans op werk (Wevers et al., 1993). De reden hiervoor is dat in dat geval hoge eisen worden gesteld aan de flexibiliteit van de onderneming en van de collega's.

In relatie tot ziekte is het van belang de invloed op succesvolle reïntegratie van de factor arbeidsongeschiktheid zelf, niet te onderschatten. Het gegeven dat een persoon arbeidsongeschikt is, heeft een enorme psycho-sociale impact op de persoon zelf en diens omgeving. Zoals beschreven in paragraaf 1.4 werkt het in Nederland gehanteerde beoordelingssysteem van de mate van arbeidsongeschiktheid een voortschrijdend invalideringsproces in de hand. Arbeidsongeschiktheid kan derhalve leiden tot een verslechtering van de aanvankelijke gezondheidstoestand van de persoon met beperkingen en aldus tot een verminderde kans op reīntegratic.

\subsubsection{Persoonskenmerken}

Factoren die zijn gerelateerd aan de persoon zelf, betreffen onder meer de motivatie, persoonlijke attitude, de eigen effectiviteit, flexibiliteit en copingstijl. Motivatie wordt in deze gedefinieerd als de intentie om (weer) aan het werk te gaan, dan wel te starten met een reìntegratieprogramma.

Motivatie wordt zowel door de persoon met beperkingen zelf als door vertegenwoordigers van begeleidende en bemiddelende instellingen genoemd als een belangrijke reden voor succesvolle reìntegratie (Rosenthal, 1974; Griffiths, 1977; Clark et al., 1981; Anthony \& Jansen, 1984; Berghoeff et al.. 1987; Fitzgerald et al., 1989; Michon \& Van Weeghel, 1990; Weiser \& Cedraschi, 1992; Veerman \& Cavé, 1994: Van der Stelt et al., 1996). Motivatie wordt in deze studies veelal indirect gemeten aan de hand van het zoekgedrag van personen. De mate waarin personen 
zoekgedrag vertonen lijkt een betere uitdrukking te zijn van de aanwezige motivatie dan door attitudemeting.

Riipinen et al. (1994) constateren dat motivatie een van de belangrijkste verklarende factoren is die de kans op succesvolle reïntegratie beïnvloedt. Daarnaast blijkt een gebrek aan motivatie een van de belangrijkste oorzaken voor uitval bij een reīntegratieprogramma, gericht op uitstroom naar de reguliere arbeidsmarkt (Ernste et al., 1995). Echter motivatie in de vorm van zoekgedrag alleen blijkt niet voldoende. In een studie van Molenaar-Cox \& Prins (1998) naar de arbeidsmarktpositie van WAObeoordeelden, blijkt dat van de personen die één jaar na beoordeling niet werken, $69 \%$ actief heeft gezocht naar een baan. Van der Stelt et al. (1996) vinden echter een duidelijke samenhang tussen motivatie en de mate van zoekgedrag alsmede tussen de mate van zoekgedrag en de kans op werk bij een nieuwe werkgever. Berghoeff et al. (1987) geven aan geen verschil te hebben gevonden in de mate van zoekgedrag tussen succesvol en niet-succesvol gereìntegreerde personen met beperkingen, maar voegen hieraan toe dat gereīntegreerde werknemers met beperkingen effectiever naar werk hebben gezocht dan niet-werkende personen met beperkingen. Van der Aa \& Vlaanderen (1991) stellen op grond van verschillende onderzoeken eveneens vast dat er een relatie is tussen arbeidsmotivatie en arbeidsmogelijkheden. Mensen met een geringe kans op de arbeidsmarkt zullen over het algemeen minder gemotiveerd zijn voor werk dan mensen met goede kansen.

Motivatie wordt in die zin als een van de kernelementen beschouwd die verantwoordelijk zijn voor een geslaagde reīntegratie. Het betreft daarbij zowel het aantal activiteiten dat wordt uitgevoerd, als de intentie om te reïntegreren. Deze intentie wordt vervolgens ingegeven door onder meer de attitude die de persoon met beperkingen heeft ten aanzien van het ondernemen van activiteiten richting werkhervatting en de inschatting van de persoon of hij/zij in staat deze activiteiten met succes uit te kunnen voeren, de eigen effectiviteit (De Vries, Kuhlman \& Dijkstra, 1987). In een studie van Regenold et al. (1999) blijkt de mate waarin de persoon met beperkingen zich zelf in staat acht te reïntegreren op de reguliere arbeidsmarkt (m.a.w. de inschatting van de eigen effectiviteit), een belangrijke voorspeller te zijn voor de daadwerkelijke slaagkans. Uit een studie van Mann (1994) naar kenmerken van succesvol gereïntegreerde werknemers met beperkingen, blijkt met name een positieve attitude ten aanzien van werk van doorslaggevende betekenis te zijn voor hun succes. Het ontbreken van een dergelijke attitude hangt sterk samen met het niet succesvol zijn in het terugkeren naar de reguliere arbeidssituatie. Dit blijkt uit een follow up studie van Eklund (1992) naar factoren die op de lange termijn van invloed zijn op arbeidsparticipatie. Voor personen met ernstige beperkingen is een positieve attitude 
noodzakelijk om de reïntegratiekansen te vergroten. Hiermee wordt zowel naar een positieve attitude ten opzichte van werk gerefereerd, als naar de persoonlijke attitude ten opzichte van de eigen (on)mogelijkheden, c.q. de wijze waarop wordt omgegaan met de eigen beperkingen (Riipinen et al., 1994; Bowe, 1985; Gründemann \& Nijboer, 1998).

Het goed kunnen omgaan met de eigen beperkingen heeft bij sollicitaties een positieve invloed op de beeldvorming van de potentiële werkgever. Vaak blijkt echter de persoon met beperkingen zelf onvoldoende in staat te zijn de eigen ziekte of aandoening op een objectieve, niet stigmatiserende wijze kenbaar te maken, waardoor de kans op aanname in negatieve zin wordt beïnvloed (Thomas \& Menz, 1996). Het aanleren van goede arbeidsgerelateerde communicatievaardigheden blijkt een positief effect te hebben op de aannamekans bij sollicitaties (Thomas \& Menz, 1996). Echter een te hoog ambitieniveau dat niet overeenkomt met datgene wat tot iemands mogelijkheden behoort, kan een belemmerende factor zijn binnen een sollicitatieproces (Van Elderen et al., 1995).

Onderdeel van de attitude ten aanzien van werk in het algemeen betreft de flexibiliteit van de te reïntegreren persoon. In een aantal studies wordt een verband gevonden tussen de mate van flexibiliteit en het al dan niet succesvol reïntegreren en functioneren op de arbeidsmarkt van mensen met beperkingen. Met name voor het behoud van een baan op de lange termijn blijkt een flexibele werkhouding noodzakelijk, aangezien de gereïntegreerde werknemer met beperkingen (net als overigens alle werknemers) in staat moet zijn in te spelen en open te staan voor de voortdurend veranderende werkomstandigheden (Berg, Flynn \& Wacker, 1997).

De mate waarin en de snelheid waarmee een persoon met een ziekte of aandoening in staat zal zijn om om te gaan met de eigen beperkingen, met andere woorden, zich aan te passen aan deze ziekte of aandoening, is volgens Livneh \& Antonak (1997) afhankelijk van de interactie tussen een viertal variabelengroepen. Zij baseren hun vierdeling op een aantal eerder gepubliceerde theorieën en modellen ten aanzien van adaptatie aan een chronische ziekte of aandoening. Het betreft variabelen gerelateerd aan de beperking (onder meer oorzaak, chroniciteit, ernst, zichtbaarheid), variabelen gerelateerd aan sociodemografische kenmerken (geslacht, leeftijd, beroep. sociaal economische status, opleidingsniveau, aanwezige arbeidsvaardigheden), variabelen gerelateerd aan persoonlijke en gedragsmatige eigenschappen (bijv. de aanwezige copingstrategieèn, locus of control, attitudes t.a.v. gezondheid en ziekte, acceptatie van de beperking, zelfbeeld, intellectuele capaciteiten) en variabelen geassocieerd met de fysieke en sociale omgeving (sociale ondersteuning, economische en institutionele ondersteuningssystemen, fysieke bereikbaarheid, attitudes van anderen, stigma). 


\subsection{OMGEVINGSGEBONDEN FACTOREN}

De omgeving waarin de persoon met beperkingen verkeert kan op verschillende niveau's worden gedefinieerd, namelijk op macroniveau, zijnde de maatschappelijke omgeving, waarin de te reĭntegreren persoon verkeert, op microniveau, zijnde de directe sociale omgeving waartoe de persoon behoort, maar ook op mesoniveau, i.c. de omgeving waarbinnen de persoon zich bevindt tijdens het proces van reintegratie naar de arbeidsmarkt.

Onderzoek, en dus gegevens omtrent succesvolle reintegratie in relatie tot de invloed van de directe sociale omgeving, ontbreekt vrijwel geheel. Toch lijkt het evident dat de sociale omgeving een sterke invloed zal blijken te hebben op de mate waarin een persoon met beperkingen sociaal actief zal zijn of zich actief zal richten op arbeidsreĩntegratie. De sociale omgeving kan stimulerend zijn met betrekking tot de arbeidsreìntegratie, maar kan ook inhiberend zijn. In dat laatste geval probeert de sociale omgeving te voorkomen dat de persoon opnieuw wordt blootgesteld aan de belasting binnen de werksituatie.

\subsubsection{Maatschappelijke factoren}

Binnen de maatschappelijke factoren kunnen worden onderscheiden, factoren betrekking hebbende op de arbeidsmarkt, de beeldvorming met betrekking tot werknemers met een beperking en factoren betrekking hebbende op de wet- en regelgeving. De invloed van de wet- en regelgeving op reïntegratie is reeds beschreven in paragraaf 1.3 en zal hier niet meer aan de orde worden gesteld.

\section{De arbeidsmarkt}

Wanneer wordt gekeken naar factoren gelegen binnen de arbeidsmarkt die de kans op reïntegratie beïnvloeden, kunnen daarbij twee factoren worden onderscheiden, namelijk de krapte op de arbeidsmarkt en het type baan.

Uit overzichtsstudies van Mul et al. (1995) en Ernste et al. (1995) naar reïntegratiemethoden voor mensen met een arbeidshandicap komt naar voren dat een ruime arbeidsmarkt (ruim aanbod aan personeel, hogere werkloosheid) kan leiden tot belemmeringen bij de reïntegratie van mensen met beperkingen. Immers, denkend vanuit een profijtbeginsel proberen werkgevers bij de werving en selectie van nieuw personeel risico's zoveel mogelijk te vermijden. Werkgevers zullen dus niet alleen letten op opleiding en werkervaring maar ook of de persoon snel en zonder problemen kan worden ingewerkt, en voor langere tijd - zonder al te veel onderbrekingen werkzaam blijft bij het bedrijf. Aangezien deze informatie vaak moeilijk te krijgen is, 
gaan werkgevers af op globale indrukken die men heeft van de persoon én van de stereotypen over de categorie waartoe de persoon behoort (Van den Berg \& Van der Veer, 1993). Bij een ruim aanbod van personeel op de arbeidsmarkt zal de persoon met een arbeidshandicap dus niet de eerste keuze zijn voor een werkgever.

Het type baan blijkt eveneens van invloed op de kans op reïntegratie voor mensen met een arbeidshandicap. Naarmate de vraag vanuit de markt beroepen betreft waar minder zware fysieke eisen aan de persoon worden gesteld, zal voor personen met een arbeidshandicap de kans op het vinden van werk dat geen belemmeringen oplevert, toenemen. Door de verandering die in de afgelopen decennia heeft plaatsgevonden van een industriële samenleving naar een dienstverlenende samenleving is het type banen eveneens veranderd. De dienstverlenende beroepen vereisen minder zware fysieke vaardigheden, waardoor er meer werkmogelijkheden ontstaan voor mensen met beperkingen, hetgeen de reïntegratiekansen bevordert (Bowe, 1985; Kiernan, Schalock \& Knutson, 1989). Dit voordeel geldt met name voor personen met een fysieke beperking, daarentegen kan deze verandering naar meer dienstverlenende beroepen voor personen met psychische beperkingen belemmerend werken. Voor deze laatste groep lijken de steeds hogere eisen binnen de dienstverlenende beroepen met betrekking tot de sociale vaardigheden, de flexibele inzet en het kunnen werken onder hoge werkdruk, de arbeidsintegratie te belemmeren (Ketting \& Bijl, 1990; Bluestone, 1990; Weis, 1993). Ook Oliver (1993) geeft aan dat door de toenemende automatisering, ontstaan in het huidige post-industriele tijdperk nieuwe kansen op werk zou kunnen bieden voor mensen met een arbeidshandicap. Echter, voor de hierdoor ontstane banen is vaak een hogere opleiding nodig dan wel de mogelijkheid om de voor het betreffende beroep benodigde vaardigheden te ontwikkelen. Een groot deel van de populatie personen met een arbeidshandicap heeft geen hogere opleiding en is volgens Oliver vaak, door fysieke en/of psychische barrières, niet in staat de hiervoor benodigde competenties te ontwikkelen.

\section{Beeldvorming}

De wijze waarop in een samenleving naar de persoon met een arbeidshandicap wordt gekeken, de beeldvorming, is van grote invloed op succesvolle reïntegratie. Een positieve beeldvorming en een daarmee gepaard gaande sociale steun zullen de kansen op reintegratie van personen met een arbeidshandicap vergroten (Van Elderen et al., 1995; West, 1996).

Door Dear et al. (1997) worden acht factoren onderscheiden die van invloed zijn op de maatschappelijke beeldvorming. c.q. acceptatie van personen met een beperking, namelijk (1) de functionaliteit; hoe groter de functionaliteit van mensen, hoe groter de 
acceptatie, (2) esthetiek; de mate waarin de beperking zichtbaar is en de mate waarin de beperking afwijkt van de maatschappelijk geaccepteerde normen van verschijning, (3) informele (bestaande) regels ten aanzien van sociale contacten; wanneer een beperking van iemand andere personen ongemakkelijk laat voelen, of wanneer de beperking zorgt voor onvoorspelbaar gedrag dan zal dit invloed hebben op de normale omgang met deze persoon, waarschijnlijk leidend tot vermijdingsgedrag. (4) individuele verantwoordelijkheid; naarmate de beperking van een persoon meer wordt gezien als zijnde zijn/haar eigen verantwoordelijkheid, neemt de acceptatie van deze beperking af, (5) onvoorspelbaarheid en gevaar; naarmate iemands gedrag meer onvoorspelbaar is, dan wel een gevaar zou kunnen opleveren bij contact, neemt de mate van acceptatie af, (6) behandelbaarheid; naarmate een beperking beter te behandelen is, neemt de acceptatie toe, (7) empathie; de mate waarin personen bereid zijn zich empathisch op te stellen ten opzichte van een bepaalde beperking, neemt de acceptatie toe, en ( 8 ) besmettelijkheid; wanneer een beperking besmetting zou kunnen opleveren voor de ander, neemt de acceptatie af.

De invloed van de hierboven genoemd acht factoren kan afnemen, naarmate de persoon met beperkingen meer in contact komt met anderen, vanwege een toename van bekendheid met de beperking en door de mogelijkheid tot het wegnemen van vooroordelen. Naarmate een persoon vanwege een bijzonder lage mate van acceptatie minder in contact komt met anderen, en in die zin een grotere sociale afstand heeft, zal de kans op het vergroten van de acceptatie kleiner worden en dus daarmee de kans op reĭntegratie. Zo blijken personen met een beperking voordeel te hebben van het persoonlijk kennen van werkgevers. In diverse onderzoeken wordt dit gegeven bevestigd (Van den Berg \& Van der Veer, 1990a en b; Michon \& Van Weeghel, 1990; Van der Aa \& Vlaanderen, 1991; Dauwalder \& Hoffman, 1992; Kers et al., 1996; Van der Stelt, Fiseler, Smaal, Molenaar-Cox \& Kers, 1996; Collijn. Van Lierop \& Nijhuis, 1996). Vandaar dat Dear et al. (1997) ook stellen dat de mate van acceptatic an sich een zelfstandig acceptatie criterium vormt.

\subsubsection{Factoren gerelateerd aan het proces van reïntegratie}

Het proces van reïntegratie voor personen die arbeidsongeschikt zijn verklaard vanwege de aanwezige beperkingen kan worden vormgegeven via een reïntegratieprogramma. Het al dan niet volgen van dergelijke programma's kan van invloed zijn op succesvolle reïntegratie. Daarnaast kunnen factoren die van invloed zijn op het succes van reïntegratie betrekking hebben op de inhoud van deze reïntegratieprogramma's. In deze paragraaf wordt aangegeven in hoeverre het al dan niet volgen van een reïntegratieprogramma van invloed is op succesvolle reïntegratie. 
Daarnaast wordt een overzicht gegeven van factoren binnen een reĩntegratieprogramma die hierop van invloed kunnen zijn, waarbij specifiek aandacht wordt besteed aan de invloed van het volgen van een scholingstraject gedurende een reïntegratieprogramma.

\section{Succes door deelname aan een reïntegratieprogramma}

Uit meerdere studies blijkt het volgen van een reïntegratieprogramma een positieve invloed te hebben op de kansen op werk na afloop hiervan (Gogstadt, 1968; Cook, 1983; Morgan \& O'Connell, 1987; Crepeau \& Scherzer, 1993; Brejc, 1994; Hennessey \& Muller, 1995; Schmidt, Oort-Maarburger \& Meijman, 1995; Selander et al., 1998). Een economische evaluatie, uitgevoerd binnen een quasi-experimenteel onderzoeksdesign, laat zien dat reïntegratieprogramma's in het algemeen kosten-effectief zijn (Collijn et al., 1996; Dean, Dolan \& Schmidt, 1999).

Niet alleen de kans op werk blijkt te stijgen door het volgen van een reïntegratieprogramma, ook wordt gevonden dat personen met beperkingen die een reïntegratieprogramma hebben doorlopen, significant minder dagen ziek zijn dan voorheen, ongeacht hun werkstatus (Selander et al., 1998). Daarnaast constateert Brejc (1994) in een evaluatiestudie naar intensieve reìntegratieprogramma's dat na afloop ervan een verbetering optreedt in de sociale participatie van deelnemers aan dergelijke programma's.

De studies van Brejc (1994) en Selander et al. (1998) zijn in die zin uitzonderlijk dat in vrijwel alle studies naar het resultaat van reïntegratieprogramma's, alleen wordt gekeken naar plaatsingscijfers. Het vinden van werk na afloop van een reïntegratieprogramma kan worden gezien als succesvol, maar andere factoren zoals veranderingen op psychosociaal niveau of functioneren in de werksituatie kunnen eveneens worden gezien als succesvolle uitkomsten. Deze worden echter nauwelijks gemeten. Eveneens zijn er vrijwel geen studies bekend waarbij inzicht wordt gegeven in de beginsituatie van de personen die een reïntegratieprogramma doorlopen, waarbij bijvoorbeeld de uitkomsten uit de assessment bij aanvang van een programma, de daarop gebaseerde interventies en het succes van deze interventies worden meegenomen.

\section{Inhoud reïntegratieprogramma's in relatie tot succesvolle reìntegratie}

De inhoud van een reintegratieprogramma, gericht op blijvende arbeidsparticipatie, is van belang voor het succes ervan. Tevens heeft de wijze waarop arbeidsreïntegratieprogramma's zijn georganiseerd c.q. worden vormgegeven, een directe impact op het resultaat van deze programma's (Kirschenbaum, 1999). 
Wilgosh \& Muller (1993) concluderen dat de kans op succesvolle reĩntegratie wordt vergroot wanneer reīntegratieprogramma's aandacht besteden aan het trainen van zowel persoonlijke vaardigheden, sociale vaardigheden als werkgerelateerde vaardigheden. Specifieke aandacht hierbij betreft het aanleren van een flexibele werkhouding. vanwege de voortdurend veranderende werkomgeving (Berg, Flynn \& Wacker, 1997). Een reïntegratieprogramma waarbinnen wordt gewerkt met kleine groepen, en waarin iedereen een geïndividualiseerd programma kan volgen, blijkt eveneens van wezenlijke invloed op succesvolle reîntegratie (Lubbe, 1990; Mul et al., 1995; Bolton \& Akridge, 1995).

De mate van intensiteit van een reìntegratieprogramma blijkt niet gerelateerd aan de mate van succesvolle reìntegratie (Brejc, 1994). Indien iedere willekeurige aandoening wordt meegenomen, blijken verschillen in intensiteit van reìntegratieprogramma's geen effect te hebben op het plaatsingssucces. Wel blijken zeer intensieve reïntegratieprogramma's voor personen met een traumatisch hersenletsel en personen met aandoeningen van het bewegingsapparaat effectief, wanneer het gaat om langdurig succesvolle reïntegratie (Ahlgren \& Hammarstrom, 1999; Groswasser, Melamed, Agranov \& Keren, 1999).

Personen die een scholingsprogramma volgen tijdens een reĭntegratieprogramma, hebben méér kans op werk en op een betere toekomstige economische status dan personen die tijdens het volgen van een reĩntegratieprogramma geen scholing volgen (Gogstadt, 1968).

Uit een overzichtsstudie naar reïntegratiemethoden van Mul et al. (1995) blijkt dat scholing een belangrijke voorwaarde vormt om weer aan het werk te komen voor personen met een arbeidsongeschiktheidsuitkering vanwege een of meerdere beperkingen. Ernste et al. (1995) voegen hieraan toe dat met name scholing succesvol is in te zetten als arbeidsreïntegratiemiddel wanneer het beroepsgerichte scholing betreft. Wanneer deze beroepsgerichte scholing wordt aangevuld met arbeidstraining en fysieke training blijkt dit een aanvullend positief effect te hebben op de reïntegratiekansen voor personen met beperkingen (Hennessey \& Muller, 1995). Schwab \& DiNitto (1993) vinden in hun onderzoek naar gereïntegreerde werknemers met beperkingen, dat de succesvol gereīntegreerde werknemers een reĩntegratieprogramma hebben doorlopen waarin relatief veel aandacht wordt besteed aan het in kaart brengen van de mogelijkheden van de persoon en een hierop gerichte scholing en training. Unger (1994) heeft de reïntegratie kansen voor personen met psychische beperkingen bestudeerd en concludeert dat de reïntegratickansen stijgen door het volgen van scholingsprogramma's. 
Het besteden van aandacht aan gerichte carrièreplanning binnen arbeidsreïntegratieprogramma's voor jongeren met psychiatrische problematiek, blijkt een overall positief effect te hebben op langdurig succesvolle reïntegratie (Ellison, Danley, Bromberg \& Palmer, 1999). Daarnaast blijkt aandacht voor de bemiddeling van personen met een arbeidsongeschiktheidsuitkering vanwege de aanwezige beperkingen van wezenlijk belang. Niet alleen de mogelijkheid tot bemiddeling, maar ook het verstrekken van goede voorlichting aan de toekomstige werkgevers alsmede het benadrukken van de kwaliteit van de sollicitanten zijn factoren die een positieve invloed blijken te hebben op succesvolle reïntegratie (Van den Berg \& Van der Veer, 1990a en b). Bemiddelingsactiviteiten worden eveneens positief beïnvloed wanneer bemiddelaars beschikken over een netwerk onder werkgevers (Lamberts, 1982; Bijlsma, 1987; Berkell, 1987; Reihl, 1988; Dauwalder \& Hoffmann, 1992).

Langdurige succesvolle reïntegratie, c.q. het behouden van werk op de lange termijn, wordt positief beìnvloed indien personen die een reïntegratieprogramma doorlopen, de mogelijkheid wordt geboden stage te lopen en begeleiding te ontvangen tijdens de eerste maanden van het werk (Dauwalder \& Hoffmann, 1992; Classen, Boesken, Krajewski, Denzer \& Hafer, 1993). Eveneens wordt langdurige succesvolle reïntegratie positief beïnvloed wanneer personen een traject volgen binnen reìntegratieprogramma's dat leidt tot een functie waarin de aanwezige beperkingen geen belemmeringen meer vormen voor het uitoefenen van deze functie (Van Elderen et al., 1995).

\subsection{BEDRIJFSGEBONDEN FACTOREN}

Een groot scala aan factoren die invloed hebben op (langdurig) succesvolle reïntegratie kan worden gelabeld als bedrijfsgebonden factoren. Het betreft onder meer de grootte van het bedrijf, de bedrijfssector, de organisatie van de arbeid, het beleid ten aanzien van reîntegratie en de beeldvorming binnen het bedrijf. De invloed die deze factoren (kunnen) hebben op het al dan niet reïntegreren en langdurig succesvol functioneren in de werksituatie zullen in het hiernavolgende worden besproken.

\section{Bedrijfsgrootte}

Door meerdere onderzoekers wordt geconstateerd dat kleinere bedrijven vaker personen met een arbeidsongeschiktheidsverleden in dienst nemen dan grotere bedrijven (Bremer \& Corten,1990; Michon \& Van Weeghel,1990; Veerman \& Cavé, 1994). Bij grotere bedrijven is de kans op reîntegratie van de eigen werknemers die 
arbeidsongeschikt raken binnen het bedrijf, groter. Een verklaring die hiervoor wordt gegeven is onder meer dat in grotere bedrijven een ruimer aanbod van alternatieve functies aanwezig is en functies gemakkelijker zijn aan te passen. Ook hebben grotere bedrijven vaak een meer professioneel personeelsbeleid (Nijhuis \& Soeters, 1983; Nijhuis \& Bullinga, 1987).

In een studie naar de reïntegratiekansen voor chronisch zieken vinden Van Elderen et al. (1995) dat in alle bedrijven weerstand bestaat tegen het aannemen van personen met een chronische beperking, maar dat de redenen van afwijzing verschillen. Leidinggevenden van kleine en middelgrote bedrijven geven toe dat een eventuele aandoening tijdens de sollicitatie procedure al voor uitsluiting zorgt, terwijl grote bedrijven functiegericht zoeken en personen afwijzen op oneigenlijke gronden, zoals verminderde flexibiliteit van de persoon met chronische beperkingen.

\section{Bedrijfssector}

Wanneer in een bedrijfssector relatief veel personen met beperkingen werkzaam zijn. zal de kans waarschijnlijk groter zijn dat een persoon met een arbeidsongeschiktheidsuitkering vanwege een of meerdere beperkingen in deze sector een baan vindt, dan wanneer dat niet het geval is. Bij de overheid werken relatief minder personen met beperkingen dan binnen de marktsector. Binnen de marktsector blijken grote verschillen te bestaan in het aantal in dienst hebbende personen met beperkingen. Onder meer in de industrie, de dienstverlening en de bouw werken relatief veel personen met beperkingen, terwijl in de horeca en de detailhandel relatief weinig personen met beperkingen in dienst zijn (Nijhuis \& Bullinga, 1987; Ter Huurne et al., 1990; Bremer \& Corten, 1990; Bosselaar \& Van Heertum, 1993). Veerman \& Cavé (1993) constateren dat in de sectoren handel en horeca de meeste bedrijven voorkomen waar helemaal geen personen met beperkingen in dienst zijn.

\section{Organisatie van de arbeid}

De organisatie van de arbeid heeft een relatie met de kans op succesvolle reìntegratie voor personen met een arbeidsongeschiktheidsuitkering vanwege de aanwezige beperkingen. In organisaties waar bijvoorbeeld veel in teamverband wordt gewerkt, worden minder personen met een arbeidsongeschiktheidsverleden aangenomen dan in organisaties waar veel alleen wordt gewerkt (Nijhuis \& Bullinga, 1987; Bremer \& Corton, 1990). Een verklaring die hiervoor wordt gegeven is dat in taakgroepen hoge eisen worden gesteld aan de flexibiliteit en inzetbaarheid van de werknemer, eigenschappen waarover werknemers met beperkingen in mindere mate zouden beschikken. Een andere of aanvullende verklaring kan liggen in de bereidheid van 
collega's om samen te werken met een werknemer met een beperking. Het blijkt dat deze bereidheid (evenals de bereidheid van de chef) van doorslaggevend belang is voor een succesvolle (her)plaatsing (Michon \& Van Weeghel, 1990).

\section{Beleid van het bedrijf}

De wijze waarop binnen een bedrijf het beleid ten aanzien van reïntegratie wordt vormgegeven, heeft invloed op de kans die een persoon met beperkingen heeft om bij dat bedrijf te worden aangenomen. Volgens Kenny (1995) moet de oorzaak voor het niet in dienst nemen van mensen met beperkingen, onder meer worden gezocht in het gegeven dat de werkzaamheden binnen het bedrijf niet zijn afgestemd op de mogelijkheden van werknemers met beperkingen. Ter Huurne, Veerman, Van Deursen, Schellekens \& Vissers (1997) delen deze conclusie en voegen hier aan toe dat deze afstemming kan worden bevorderd - en daarmee de aanname van personen met beperkingen - door een goed ontwikkelde medezeggenschapsraad, een breed ontwikkeld arbobeleid en de bereidheid van het bedrijf om aanpassingen te verzorgen. Wanneer binnen een bedrijf onvoldoende kennis aanwezig is omtrent instrumenten die de reìntegratie aantrekkelijker maken, heeft dit een negatieve invloed op het aannamebeleid (Kenny, 1995).

\section{Attitude werkgevers}

Personen met een arbeidsongeschiktheidsuitkering ontvangen deze uitkering vanwege de aanwezigheid van een of meerdere beperkingen. Door de aanwezigheid van deze beperkingen kunnen vooroordelen ontstaan ten aanzien van het functioneren van hen (Dijker \& Koomen, 1996), die het handelen van werkgevers kunnen beïnvloeden. In een onderzoek van Bruggeman (1991) wordt gevonden dat de attitude van werkgevers de belangrijkste factor blijkt voor het al dan niet aannemen van personen met beperkingen. Dit gegeven wordt bevestigd door Kenny (1995), die concludeert dat een negatieve attitude ten aanzien van werknemers met beperkingen de aanname ervan belemmert. Met name voor personen met niet-zichtbare klachten, zoals onder meer diabetes of psychische klachten, zijn de kansen op aanname gering; werkgevers blijken minder geneigd personen met niet-zichtbare klachten aan te nemen (Van Elderen et al., 1995). Bergers, Nijhuis, Janssen \& Van der Horst (1999) laten daarentegen zien dat er geen verschil is in aanname tussen diabetici die hun diabetes hebben gemeld bij de sollicitatie en diegenen die het niet hebben genoemd. Uit onderzoek naar het beslissingsgedrag van werkgevers bij sollicitanten voor laaggeschoolde functies, blijkt dat gezondheid een van de belangrijkste selectiecriteria is voor werkgevers (Van Beek 
\& Van Praag, 1992). Dit selectiecriterium beĩnvloedt de attitude van werkgevers ten aanzien van de aanname van arbeidsgehandicapten.

De reeds genoemde studie van Bruggeman (1991) richt zich op de kleinere bedrijven waar, ondanks een gemiddeld neutraal beeld, nog veel stereotype ideeěn bestaan over het functioneren van personen met beperkingen: de werknemer met beperkingen verzuimt meer, is minder productief, vraagt meer aandacht en doet vaker een beroep op collega's. In een onderzoek van Veerman \& Cavé (1993) wordt gevonden dat de houding van werkgevers ten aanzien van het in dienst hebben van arbeidsongeschikte werknemers, in het algemeen niet negatief blijkt te zijn. Een gunstig of in ieder geval neutraal beeld hebben de werkgevers met name wat betreft de acceptatie door collega's, de gemotiveerdheid en de productiviteit. Ongunstig wordt vooral gedacht over de nodige extra begeleiding die deze werknemers zouden moeten krijgen en de kans op (hernieuwde) langdurige uitval. Ruim een kwart van de werkgevers schat dat het verzuimrisico van (gedeeltelijk) arbeidsongeschikten hoger is dan dat van andere werknemers. De helft denkt dat er geen verschil is en slechts een klein deel $(5 \%)$ meent dat dit risico lager is.

Collega's spelen een belangrijke rol bij het al dan niet slagen van een reïntegratiepoging. In het reeds aangehaalde onderzoek van Veerman \& Cavé (1993) wordt geconstateerd dat een nieuw aangestelde werknemer met beperkingen in eerste instantie afstandelijker wordt bejegend dan nieuw aangestelde werknemers zonder deze beperkingen. Collega's zijn veelal bevreesd voor een verhoging van de eigen arbeidsbelasting omdat ze taken van de werknemers met beperkingen moeten overnemen (Van der Aa \& Vlaanderen, 1991). Van belang voor de acceptatie en bereidheid van collega's om samen te werken met een (gedeeltelijk) arbeidsongeschikte en zelfs taken over te nemen, is duidelijkheid omtrent de aandoening en de beperkingen die dit met zich meebrengt voor het werk (Michon \& Van Weeghel, 1990). Deze duidelijkheid ontbreekt veelal bij mensen met (tijdelijke) psychische problemen en bij mensen met vage lichamelijke aandoeningen.

\section{Werkaanpassingen}

Het belang van werkaanpassingen voor het vergroten van de kans op reïntegratie komt uit verschillende publicaties naar voren (Schultz-Johnson, 1987; Van Dijk, Haselen \& Lenshoek, 1987; Philips, 1989; Ganz, 1990; Maas, van Dongen \& Hamers, 1990; Michon \& Van Weeghel, 1990; Ter Huurne et al., 1990; Van Dooren, 1990; Mitchell, 1991; Diethelm \& Schüler, 1991; Bijl \& Lemmens, 1993; Nijboer, Gründemann \& Andries, 1993; Johns, Bloswick, Elegante \& Colledge, 1994; Grijpink, 1994; Harlan en Robert, 1998). Werkaanpassingen betreffen zowel het aanpassen van de werkplek 
(meubilair, apparatuur en dergelijke) als het aanpassen van functies op het gebied van taakinhoud, arbeidsomgeving, werktijden en werktempo.

Volgens Harlan en Robert (1998) hangt het al dan niet verkrijgen van aanpassingen af van drie groepen factoren, namelijk (1) het geslacht en de positie binnen het bedrijf, (2) de bereidheid van de leidinggevenden om zich te conformeren aan wettelijke regels die hiertoe min of meer verplichten en (3) het type aanpassingen dat wordt gevraagd. In hun kwalitatief onderzoek bij verschillende bedrijven blijkt dat aanvragen van vrouwen alsmede aanvragen van personen uit de lagere echelons meer worden afgewezen in vergelijking met mannen en personen uit de hogere echelons. Een verklaring die de onderzoekers geven is dat in de laagst betaalde beroepen minder variatie bestaat in taken. Wanneer personen een bepaalde taak niet meer kunnen uitvoeren, betekent dit in veel gevallen het beroep niet meer kunnen uitoefenen. In dat geval zijn werkgevers minder bereid om aanpassingen te verrichten, in hun perceptie is het dan gemakkelijker een ander het werk te laten doen. Ten aanzien van punt 2 , blijkt dat naarmate werkgevers meer bereid zijn zich te conformeren aan wettelijke regels ten aanzien van het verzorgen van aanpassingen, worden aanvragen voor aanpassingen meer ingewilligd. Tenslotte worden aanvragen voor relatief eenvoudige aanpassingen eerder ingewilligd dan aanvragen voor relatief moeilijk realiseerbare aanpassingen. De 'prijs' van aanpassingen zou geen belemmering voor werkgevers moeten vormen, immers uit meerdere studies is gebleken dat de gemiddelde kosten voor aanpassingen vrij laag zijn (Blanck, 1996; Granger \& Baron, 1996). Bovendien blijken bij duurdere aanpassingen, de kosten van aanpassing veel minder te bedragen dan de productiviteit en de prestaties die worden behaald door de persoon met beperkingen die deze aanpassing nodig heeft (Harris, 1995).

In het kwalitatief onderzoek van Harlan en Robert (1998) is gebruik gemaakt van grounded theory teneinde een dieper inzicht te krijgen in de beweegredenen van werkgevers om al dan niet aanpassingen te verzorgen. Zij zoeken de verklaring voor de weerstand van leidinggevenden ten aanzien van het verzorgen van aanpassingen onder meer in de behoefte van werkgevers van het behouden van controle over hiërarchie en autoriteit. Als bepaalde aanpassingen niet alleen interessant zijn voor de persoon met beperkingen, maar ook voor niet beperkte werknemers, is het risico voor de leidinggevende te groot dat anderen dan de persoon met beperkingen deze aanpassing eveneens willen. Daarnaast bestaat bij leidinggevenden de angst dat werknemers met beperkingen die om niet-materiele aanpassingen vragen, daardoor teveel zeggenschap en dus controle krijgen over de invulling van het werk.

Michon \& Van Weeghel (1990) noemen in hun rapport over werken met beperkingen de weerstand tegen het aanpassen van werk als een van de knelpunten bij reîntegratie. 
Michaels en Risucci (1993) vullen aan dat deze weerstand bij werkgevers voortkomt uit de idee van werkgevers dat het regelen van individuele aanpassingen oneerlijk is ten opzichte van collega's die geen aanpassingen nodig hebben, het regelen van aanpassen te veel tijd in beslag neemt en te duur is.

Uit onderzoek van Ter Huurne et al. (1990) blijkt dat werkgevers ten behoeve van werknemers met beperkingen maar weinig aanpassingen van de werkplek of de werkomgeving realiseren. Dit hoeft niet te betekenen dat werkgevers hierin tekortschieten, de werknemer met beperkingen die een baan vindt bij een nieuwe werkgever blijkt vaak geen aanpassingen nodig te hebben (Veerman \& Cavé, 1993).

\subsection{BEÏNVLOEDBARE FACTOREN}

Bij de reīntegratie van mensen die vanwege een ziekte of aandoening arbeidsongeschikt zijn verklaard zal zoals reeds is aangegeven in hoofdstuk 1, de mate van participatie in de betekenis van het vinden en behouden van een baan, met name worden beïnvloed door de mate waarin een persoon met een specifieke ziekte of aandoening bepaalde activiteiten kan uitvoeren, door persoonlijke en externe factoren en door de wisselwerking hiertussen. Vergroting van de uitstroom zal echter slechts dan mogelijk zijn, wanneer de genoemde factoren daadwerkelijk te beïnvloeden zijn. In deze paragraaf zal kort worden weergegeven welke van de persoonsgebonden factoren, omgevingsgebonden factoren en bedrijfsgebonden factoren, beschreven in de paragrafen $2.1,2.2$ en 2.3 te beïnvloeden zijn.

\section{Persoonsgebonden factoren}

Van de genoemde persoonsgebonden factoren die van invloed zijn op succesvolle reïntegratie zijn in feite twee factoren mogelijk te beïnvloeden. De ene factor betreft het verhogen van het opleidingsniveau van de te reïntegreren persoon met beperkingen, de andere factor heeft betrekking op de wijze waarop personen met beperkingen hun gezondheid beleven en daaraan gerelateerd hoe ze omgaan met hun beperkingen.

Het merendeel van de personen uit de WAO-populatie is werkzaam geweest in de lagere beroepen. Gerichte scholings- en trainingsprogramma's zouden moeten worden gevolgd teneinde niet alleen te streven naar een herstel (vergroten van de mogelijkheden om om te gaan met een beperking) maar ook naar een daadwerkelijke verbetering van de sociale, economische en maatschappelijke positie (zie paragraaf 2.2.2). 


\section{Omgevingsgebonden factoren}

Wanneer wordt gekeken naar de omgevingsgebonden factoren blijkt de wet- en regelgeving op het gebied van de sociale zekerheid tot op heden weinig invloed te hebben op de omvang van de WAO in- en uitstroom (Parlementaire enquête, 1993; Jehoel-Gijsbers \& van der Giezen, 2000). Indien er al sprake is van een invloed blijkt deze negatief (zie paragraaf 1.3). Factoren als een ruime of krappe arbeidsmarkt en een verschuiving van productie naar dienstverlening zijn factoren, die weliswaar van invloed zijn, maar die slechts constateerbaar zijn en derhalve niet veranderbaar en beïnvloedbaar. De beeldvorming met betrekking tot de arbeidsmogelijkheden van arbeidsongeschikten en de economische positie van de gereïntegreerde werknemer zijn in beginsel beïnvloedbaar. Hier dient de kanttekening te worden geplaatst dat het aanpakken op macro niveau van het verschijnsel vooroordelen, stigmatisering en stereotypering (beeldvorming) om specifieke gedragsveranderingsstrategieën vraagt die dermate complex zijn (zie onder meer Damoiseaux, Van der Molen \& Kok, 1993), dat kan worden gesteld dat de beïnvloedbaarheid op korte termijn gering is.

\section{Reintegratieprogramma's}

Het volgen van een reïntegratieprogramma, waarbij specifieke aandacht wordt gegeven aan het trainen van persoonlijke vaardigheden, van sociale vaardigheden en van werkgerelateerde vaardigheden, waarbij wordt gewerkt in kleine groepen, waarbij werkervaring kan worden opgedaan in de vorm van een stageperiode, en waarbij wordt opgeleid voor een functic waarin de aanwezige beperkingen geen belemmering vormen voor het uitoefenen van de functie, blijkt succesvol. Bovendien betreft het volgen van een reïntegratieprogramma een interventie die volledig beïnvloedbaar is. Reîntegratieprogramma's kunnen alle bovengenoemde elementen bevatten en derhalve de succeskans vergroten van de te reĭntegreren persoon met beperkingen. Het zorg dragen voor een adequate bemiddeling is eveneens een activiteit die zonder grote problemen kan worden uitgevoerd en behoort in die zin tot de veranderbare factoren die van invloed zijn op succesvolle reïntegratie.

\section{Scholingsprogramma's}

Wanneer het gaat over interventies gericht op de persoon blijkt de kans op succesvolle reintegratic positief te worden beìnvloed wanneer scholingsprogramma's worden gevolgd, waarbij specifieke aandacht wordt gegeven aan het trainen van zowel persoonlijke vaardigheden, sociale vaardigheden als werkgerelateerde vaardigheden, waarbij wordt gewerkt in kleine groepen, werkervaring kan worden opgedaan in de vorm van een stageperiode, en waarbij wordt opgeleid voor een functie waarin de 
aanwezige beperkingen geen of een zo beperkt mogelijke belemmering vormen voor het uitoefenen van de functie. Tevens is het van belang tijdens een dergelijk scholingstraject te werken aan de attitude ten aanzien van de eigen beperkingen en aan het leren om te gaan met deze beperkingen. Een dergelijk scholingsprogramma wordt afgesloten met een bemiddelingstraject, waarbij mogelijke vooroordelen bij werkgevers kunnen worden weggenomen en eventueel benodigde werkaanpassingen kunnen worden geregeld.

\section{Bedrijfsgebonden factoren}

Bedrijfsgebonden factoren die van invloed zijn op succesvolle reìntegratie en beïnvloedbaar zijn, betreffen voornamelijk het beleid van het bedrijf gericht op het aannemen en in dienst houden van personen met beperkingen, de aard van het productieproces en de mogelijkheid tot het regelen van aanpassingen van de werksituatie. De eerstgenoemde factor is reeds eerder genoemd en kan op individueel niveau worden beïnvloed via de directe bemiddeling van personen met beperkingen. De tweede factor is relatief weinig beïnvloedbaar, terwijl de derde factor, het regelen van aanpassingen van de werksituatie, een factor is die veelal eenvoudig te realiseren is.

\section{Resumerend}

Het doel van het hier beschreven overzicht van binnen en buiten de persoon gelegen factoren die van invloed (lijken te) zijn op succesvolle reïntegratie, is het bepalen van de beïnvloedbaarheid, c.q. het belang van die diverse factoren bij de terugdringing van de omvang van de WAO-populatie. Op basis van dit overzicht kan worden bepaald of de aandacht bij reĩntegratieprocessen meer gericht dient te zijn op factoren binnen de persoon, dan wel op factoren die buiten de persoon gelegen zijn.

Uit het overzicht blijkt dat een aantal factoren op macro-niveau van invloed blijken en mogelijk beïnvloedbaar zijn. Veranderingen op macro-niveau, zoals deze onder meer plaats hebben in veranderde wetgeving, zijn noodzakelijk om een betere infrastructuur te creëren voor de reïntegratie van arbeidsongeschikten. Beleidsmatige veranderingen hebben op korte termijn geen invloed op het individuele reïntegratieproces. De beschreven literatuur en onderzoeken laten een groot aantal binnen de persoon gelegen factoren zien die goed beïnvloedbaar zijn en factoren die de succeskans van op de persoon gerichte interventies beïnvloeden. Met name op de persoon gerichte interventies in de vorm van beroepsgerichte scholing, waarin aandacht voor specifieke ondersteuning en begeleiding blijken de kans op succesvolle reïntegratie sterk te 
vergroten, alsmede persoonsgerichte bemiddelingsactiviteiten waarbij wordt gestreefd naar een optimale matching tussen persoon en werk.

De in deze paragraaf 2.4 weergegeven beïnvloedbare succesfactoren zijn niet specifiek gerelateerd aan de situatie in Nederland. In die zin is de vraag in hoeverre de als succesvolle interventie beschreven beroepsgerichte scholingstrajecten in Nederland aanwezig zijn en in hoeverre dergelijke scholingsprogramma's de verschillende aspecten omvatten die als voorwaarde voor succes worden beschreven. Een antwoord op deze vraag wordt gegeven in de hiernavolgende paragraaf 2.5 .

\subsection{BEROEPSGERICHTE SCHOLING ALS REĨNTEGRATIE INSTRUMENT}

Zoals aangegeven aan het einde van de vorige paragraaf 2.4 blijken op de persoon gerichte interventies in de vorm van beroepsgerichte scholing, waarin aandacht voor specifieke ondersteuning en begeleiding, de kans op succesvolle reïntegratie sterk te vergroten.

In Nederland kunnen personen met een arbeidsongeschiktheidsuitkering vanwege een ziekte of aandoening voor een dergelijk beroepsgericht scholingstraject terecht bij in totaal vijf REA-scholingscentra, die zich op een structurele wijze bezighouden met gerichte reintegratie activiteiten voor personen met beperkingen. Het betreft de centra Hoensbroeck Centrum voor Arbeidsperspectief, Werkenrode Arbeidsintegratie, Vakopleidingen Sonneheerdt, Instituut voor Arbeidsintegratie en Scholing Heliomare en EEGA educatie ${ }^{4}$. De REA-centra hebben specifieke reïntegratiestrategieën ontwikkeld om personen die vanwege hun beperkingen volledig arbeidsongeschikt zijn verklaard, terug te brengen naar de reguliere arbeidsmarkt. Op basis van een assessment wordt een individueel einddoel vastgesteld. Dit einddoel (reīntegratie) wordt normaliter bereikt door het volgen van een één- tot tweejarig beroepsgericht scholingstraject. Verwijzing naar de centra vindt plaats op indicatie van een arbeidsdeskundige van een uitvoeringsinstelling ${ }^{5}$. Wanneer een persoon met een

4 Deze centra worden zowel in de WAGW als in de wet REA genoemd als scholingecentra specifiek voor personen met een arbeidsongeschiktheidsuitkering.

Tot begin jaren negentig vindt verwijzing plaars door medewerkers van de GMD. Vervolgens wordt in 1991 deze takk uitgevoend door arbeidsdeskundigen van de toenmalige bedrijfsverenigingen, de huidige uitvoeringsinstellingen. waama dere in 1996 wordt overgeheveld naar arbeidsvoorziening. 
arbeidsongeschiktheidsuitkering in aanmerking komt voor scholing ${ }^{6}$, wordt naar een van de vijf centra verwezen indien de kandidaat tengevolge van ziekte of gebrek voor een (her)inpassing in het arbeids-proces aangewezen is op een bijzondere, praktijkgerichte scholing, waarbij de voor de persoon noodzakelijke begeleiding aanwezig is, opleidingen elders niet toegankelijk zijn (leeftijd, toegankelijkheid) en/of wanneer voor een vergelijkbare opleiding elders formele vooropleidingseisen worden gesteld waaraan niet kan worden voldaan. Daarnaast moet de fysieke toestand van de kandidaat van dien aard zijn dat uit dien hoofde geen (overwegende) bezwaren bestaan tegen uitoefening van het beroep waarvoor wordt opgeleid (GMD, 1990).

De keuze voor scholing an sich vindt voornamelijk plaats op basis van de individuele besluitvorming van de arbeidsdeskundige. Pas in 1997 is door het Landelijk Instituut Sociale Verzekeringen een eerste aanzet gemaakt om dit keuzeproces te protocolliseren (LISV, 1997).

De doelstelling van de centra kan als volgt worden gekenschetst. Uitgaande van een assessment van de mogelijkheden van de potentiële cursisten worden scholings-en begeleidingsactiviteiten ondernomen, die moeten resulteren in betere arbeidsmarktmogelijkheden en die moeten leiden tot een versterking van de eigen effectiviteit om op een meer adequate wijze om te gaan met de maatschappelijke en individuele problemen waarmee de persoon met een beperking te maken kan krijgen.

De vijf REA-centra werken daarbij volgens een bepaalde methodiek, welke wordt weergegeven in het procesmodel arbeidsreïntegratie (zie figuur 2.1).

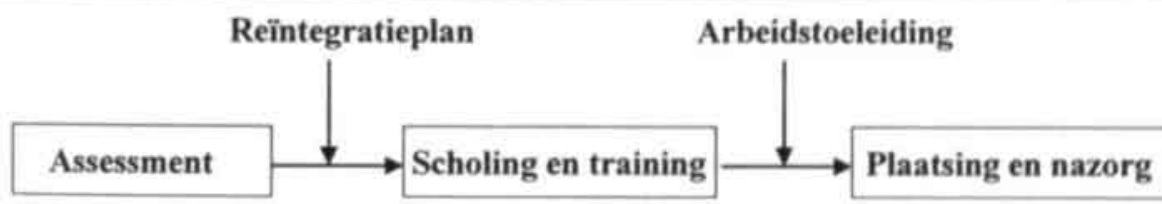

\section{Begeleiding en ondersteuning}

Figuur 2.1. Het procesmodel arbeidsreintegratie

Scholing in het algemeen wordt geindiceerd wanneer versterking van de positie van de arbeidsongeschikte nodig is. Indien de toegankelijkheid van de arteidsmarkt ontbreekt of gering is en/of de concurrentiepositie van de persoon te zwak is omdat hij/zij tekort schiet in kennis en vaardigheden voor de functie of functics waarop hij/rij is aangewezen. dan wordt scholing gezien als geschikt middel om deze lacunes op te heffen. 
Het arbeidsreïntegratieproces omvat volgens de REA-centra alle activiteiten die gericht zijn op het analyseren van de uitgangspositie van de persoon met een arbeidshandicap en het op basis daarvan ontwikkelen van een voor hem op maat gesneden reïntegratieplan. Dit reïntegratieplan omvat alle activiteiten (training, scholing, therapie e.d.) die noodzakelijk zijn om de arbeidsmarktkansen van de betrokkene te vergroten.

De eerste stap in dit proces is een uitgebreide assessment, waarbij wordt gekeken naar de mogelijkheden van de persoon. Het gaat hierbij om perceptieve, intellectuele en motorische functies (zie ook Hamcock, 1987), om de aanwezige skills, het prestatievermogen, de interesses en waarden en de specifieke biografische kenmerken (zie onder meer Roe, 1984 en Fleishman \& Quaintance, 1984). Vervolgens worden deze eigenschappen of kenmerken afgezet tegen de eisen die de arbeid stelt. Hiervoor is het noodzakelijk om niet uit te gaan van de aanvangssituatie met de op dat moment aanwezige beperkingen, maar van de resterende capaciteiten en de potentieel te ontwikkelen mogelijkheden (potentiële capaciteiten). De uitgevoerde assessment moet leiden tot bepaling van de reïntegratiebehoeften. Door middel van diverse methodieken (psychologische tests, worksamples en dergelijke) wordt nagegaan of de persoon voldoende mogelijkheden bezit om een her- of omscholing te volgen en wat het streefniveau dient te zijn. Daarnaast wordt de noodzakelijke begeleiding op sociaalpsychologisch, psychotherapeutisch, fysiotherapeutisch en medisch vlak in kaart gebracht en de betekenis daarvan bepaald met betrekking tot aanpassingen in de werksituatie en in het opleidingstraject. Op basis van deze assessment wordt een persoonlijk trajectplan ontwikkeld, waarbij aandacht wordt besteed aan de (werkgerelateerde) sociale en beroepsvaardigheden. De duur van een traject varieert van een tot twee jaar, afhankelijk van het op basis van de assessment vastgesteld einddoel. De persoon wordt gedurende het traject geleerd om zijn gerichtheid op de beperkingen - onmogelijkheden zoals deze veelal in de arbeidsongeschiktheidsperiode door WAO-keuringen door de gerichtheid op medisch-curatief handelen zijn ontstaan om te zetten naar het activeren van de resterende capaciteiten. De 'zieke' persoon zal daardoor zijn ziekenrol (ziekte als 'sickness') gaan afleggen. Dit betekent dat de persoon met beperkingen die vaardigheden aangeleerd krijgt die noodzakelijk zijn om adequaat om te gaan met zijn sociale omgeving en met een eventuele werksituatie. Bovendien leert de persoon een nieuwe functie of beroep, waarbij de impact van zijn beperkingen relatief zal zijn. Dit moet onder meer blijken uit een relatief gering aantal aanpassingen die noodzakelijk zijn om de herplaatste werknemer loonvormende arbeid te laten verrichten. Tenslotte wordt de persoon ondersteund om de aangeleerde kennis in de praktijk te brengen, in de vorm van duurzame plaatsing. 


\section{De vraagstelling}

Aangezien uit literatuuronderzoek blijkt dat beroepsgerichte scholing een succesvolle op de persoon gerichte interventie is, en dat de kans op reintegratie daarmee sterk wordt vergroot én gezien het feit dat niet bekend is in hoeverre in Nederland beroepsgerichte scholing bijdraagt aan succesvolle reìntegratie en daarmee zorgt voor een uitstroom uit de WAO, is in dit proefschrift gekozen voor de volgende centrale probleemstelling:

In hoeverre leidt het volgen van een (om)scholingstraject tot reintegratie en daarmee tot een uitstroom uit de WAO?

Voor de beantwoording van deze vraagstelling is een onderzoek verricht onder de totale populatie personen in Nederland die gedurende een bepaalde periode een (om)scholingstraject heeft doorlopen. Het onderzoek kan daarmee worden gekarakteriseerd als een niet vergelijkende cohortstudie. De resultaten van dit onderzoek, waarbij zowel de bij wet hiertoe aangewezen scholingscentra, de oud-cursisten als de werkgevers zijn betrokken, worden in dit proefschrift weergegeven. De eerder genoemde REA-scholingscentra zijn allen betrokken bij de aanlevering van deelnemers aan het onderzoek dat is verricht in het kader van dit proefschrift.

\subsection{NAAR EEN MODEL}

De werkwijze van de scholingscentra kan worden gekenmerkt als een normalisatieproces: de activiteiten binnen het reïntegratietraject zijn er op gericht om de persoon met beperkingen, via een op maat gesneden (om)scholingstraject, in staat te stellen vorm te geven aan een normale arbeidscarrière. Het op maat gesneden reïntegratieplan omvat een beroepsopleiding die zal leiden tot een functie waarin vrijwel geen aanpassingen nodig zullen zijn en de aanwezige beperkingen niet of nauwelijks als een handicap worden ervaren. Vanuit de formule van de sociale constructie gedachte gezien, wordt in die zin binnen de REA-centra de volledige aandacht gericht op de persoon en zijn/haar beperkingen. Het door de scholingscentra gehanteerde procesmodel voor arbeidsreïntegratie kan worden gecombineerd met het in figuur 1.5 (zie hoofdstuk 1) weergegeven ICIDH-2 model en vervolgens worden toegepast om de centrale vraagstelling te beantwoorden. 
Centraal in het procesmodel voor arbeidsintegratie staat de persoon aan wie vanwege de aanwezige beperkingen een volledige arbeidsongeschiktheidsuitkering is verleend en die door middel van een scholingsprogramma zich kwalificeert om zich een plaats te kunnen verwerven op de reguliere arbeidsmarkt. Op basis van een aantal persoonsgebonden kenmerken wordt een reïntegratietraject opgesteld, waarbij de nadruk wordt gelegd op het ontwikkelen van die persoonskenmerken die de kans op succesvolle reîntegratie vergroten. Onderdeel hiervan is het verkleinen van de invloed van factoren waarvan bekend is dat ze een negatieve invloed hebben op (de kans op) succesvolle reïntegratie. In het in dit proefschrift beschreven onderzoek zijn gegevens verzameld omtrent de volgende persoonsgebonden kenmerken: leeftijd, geslacht, opleidingsniveau, arbeidsverleden (niveau en sector), type aandoening, type beperking en gezondheidsstatus.

Zoals beschreven in paragraaf 2.2 is de inhoud van een scholingsprogramma van belang voor de kans op succesvolle reïntegratie. Wanneer reïntegratieprogramma's een individuele op maat gesneden werkwijze hanteren, een begeleidings- en ondersteuningscomponent bevatten alsmede een stage- en bemiddelingsperiode én cursisten door middel van een beroepsgericht scholingsprogramma worden opgeleid voor functies waarin hun beperkingen niet of nauwelijks een belemmerende werking hebben, is de kans op succesvolle reĩntegratie groter.

In het in dit proefschrift beschreven onderzoek zijn de volgende elementen van het reîntegratieprogramma meegenomen: de assessment, het beroepsgerichte scholingsgedeelte (vaktheoretische gedeelte), de begeleidings- en ondersteuningscomponent en de toeleiding naar arbeid (bemiddeling).

Een beschrijving van het scholingsprogramma is niet voldoende om een uitspraak te kunnen doen over de kwaliteit van dit programma en de waardering van dit programma door de deelnemers. De diverse aspecten binnen de beroepsgerichte scholing, de begeleidings- en ondersteuningscomponent en het bemiddelingsproces kunnen alle een specificke bijdrage leveren aan de mening van de oud-cursist over het totale scholingsprogramma. Binnen de beroepsgerichte scholing van het programma zijn te onderscheiden, de theoretische vorming. de praktische vorming. de didactische kwaliteiten van de docenten, de kwaliteit van het lesmateriaal en het niveau en tempo van het scholingsprogramma. Binnen de begeleidings- en ondersteuningscomponent zijn te onderscheiden, de begeleiding tijdens het onderwijs. de studiebegeleiding en de psycho-sociale begeleiding. Binnen de bemiddelingscomponent kan worden onderscheiden de wijze van bemiddeling en de ondersteuning tijdens de bemiddeling.

De genoemde elementen zijn in hun geheel meegenomen in het model. 
Het resultaat van deze scholingsprogramma's kan in beginsel worden afgemeten aan het aantal plaatsingen op de reguliere arbeidsmarkt, waarbij weer kan worden onderscheiden een plaatsing op korte termijn en het behouden van een plaats op de reguliere arbeidsmarkt op de lange termijn. Daarnaast zijn de scholingsprogramma's gericht op het scholen en begeleiden naar een functie waarin de aanwezige beperkingen niet of nauwelijks meer een rol spelen. In die zin is het van belang dat de gerealiseerde plaatsingen aansluiten op de gevolgde opleiding en dat er zo min mogelijk aanpassingen nodig zijn.

In dit proefschrift zal eveneens het aannameproces bij een werkgever worden beschreven waarbij de bovenstaande aspecten aan de orde zullen komen.

De REA-centra trachten door middel van intensieve training en begeleiding de persoon te ondersteunen om de eigen beperkingen op een andere wijze te laten percipiëren en daarmee om te gaan. Hiermee hoopt men te bereiken dat de persoon de aandacht gaat richten op de aanwezige resterende capaciteiten. Een groei in de persoonlijke ontwikkeling van de cursist kan daarom worden gezien als een van de resultaten van het scholingsprogramma. De persoonlijke ontwikkeling kan worden geplaatst binnen het kader van het normalisatieproces, waarbij aspecten als het beter leren omgaan met de eigen beperkingen en daarmee een verhoogd incasseringsvermogen, een toegenomen zelfvertrouwen, alsmede het toenemen van de sociale vaardigheden en tot slot een beter functioneren op de arbeidsmarkt onderdeel zijn van dit normalisatieproces.

De persoonlijke ontwikkeling heeft invloed op het al dan niet vinden van een baan na afloop van het scholingsprogramma. In die zin is de persoonlijke ontwikkeling een aparte outputvariabele, maar kan tevens worden gezien als een van de factoren van invloed op plaatsing.

De centrale vraagstelling richt zich op de mate waarin volledig arbeidsongeschikt verklaarde personen door middel van het volgen van een langdurig (om)scholingsprogramma reïntegreren en daarmee uit de WAO stromen. Gedeeltelijk wordt het antwoord op deze vraag gevonden in de plaatsingsresultaten, echter informatie over het functioneren in de werksituatie en over de behoefte aan én de realisatie van eventuele aanpassingen. geeft een meer volledig beeld als het gaat om langdurige succesvolle reïntegratie.

Ten aanzien van het functioneren in de werksituatie wordt in dit onderzock gekeken naar de algemene productiviteit van de gereïntegreerde werknemer, de vakkennis, vaktechnische vaardigheden, sociale vaardigheden, werkhouding en verzuimgedrag. 
Op basis van paragraaf 2.3 kan worden geconcludeerd dat de grootte van het bedrijf, de sector, de organisatie van het werk, het beleid ten aanzien van reïntegratie, de beeldvorming over mensen met beperkingen en het al dan niet bereid zijn werkaanpassingen te regelen invloed hebben op de kans op (langdurig) succesvolle reïntegratie. Ter completering van het gehele reïntegratie proces, kan worden nagegaan in welke bedrijven (grootte van het bedrijf, type bedrijf en de cultuur van het bedrijf), de succesvol gereîntegreerde personen terecht komen en in hoeverre de uit eerder onderzoek bekende en van invloed zijnde factoren zijn te herkennen.

Een vertaling van het procesmodel voor arbeidsreïntegratie en het ICIDH-2 model naar een analysemodel zoals dat kan worden gehanteerd voor de beantwoording van de centrale vraagstelling van dit proefschrift, waarin alle in de voorgaande tekst genoemde variabelen zijn opgenomen, staat weergegeven in figur 2.2.

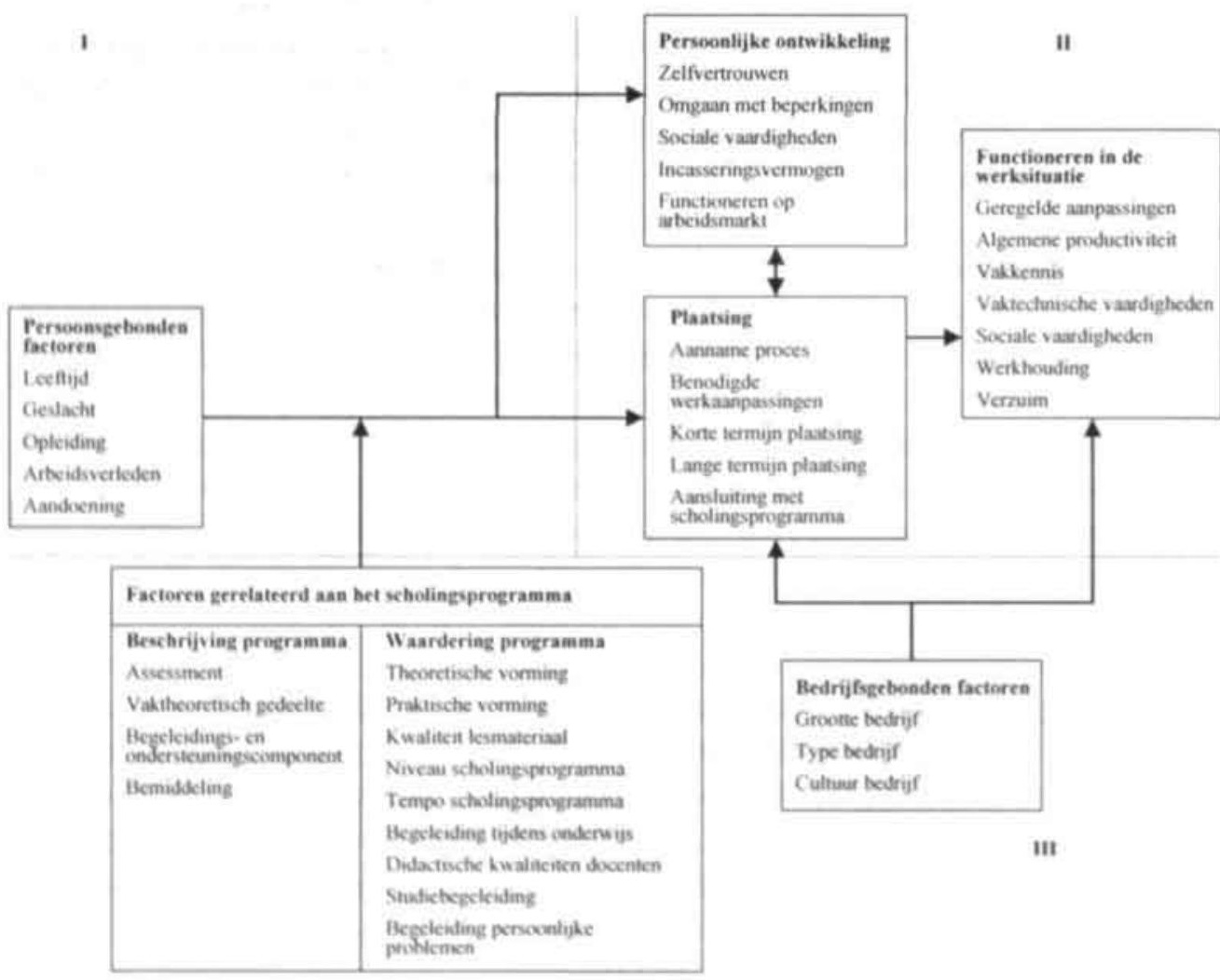

Figuur 2.2 Analysemodel voor het proces van arbeidsrelintegratic 
Vanuit het ICIDH-2 model (figuur 1.5, hoofdstuk 1) zijn de persoonlijke factoren en de gezondheidsproblemen herkenbaar binnen het blok persoonsgebonden factoren (I). Participatie wordt in het procesmodel weergegeven door de factoren plaatsing, persoonlijke ontwikkeling en functioneren in de werksituatie (II). De factoren gerelateerd aan het scholingsprogramma en de bedrijfsgebonden factoren kunnen worden gezien als externe factoren die van invloed zijn op de participatie (III).

In het analysemodel (figur 2.2) wordt weergegeven dat het effect van het scholingsprogramma verondersteld wordt afhankelijk te zijn van persoonsgebonden factoren, van factoren gerelateerd aan het scholingsprogramma zelf, de persoonlijke ontwikkeling en bedrijfsgebonden factoren. Het functioneren in de werksituatie wordt beinvloed door de wijze waarop de plaatsing tot stand is gekomen en de beroepsmatige - en sociale kwaliteiten van de persoon. Daarnaast zullen ook bedrijfsgebonden factoren van invloed zijn op het uiteindelijke functioneren in de werksituatie.

\subsection{VRAAGSTELLINGEN}

Uitgaande van de centrale vraagstelling kan een aantal deelvragen worden geformuleerd. Daarbij zullen de - binnen het in dit proefschrift gehanteerd onderzoeksmodel - betrokken partijen worden onderscheiden, namelijk de persoon met beperkingen zelf, het REA-scholingscentrum en het bedrijf waar de persoon met beperkingen eventueel een baan vindt. Inzicht in het totale proces van reìntegratie houdt in dat alle drie genoemde partijen deel moeten uitmaken van een onderzoek dat hierop is gericht.

Uitgaande van de centrale vraagstelling, "in hoeverre leidt het volgen van een (om)scholingstraject tot reïntegratie en daarmee tot een uitstroom uit de WAO", is het op de eerste plaats noodzakelijk om onderzoek te doen naar het verloop en het resultaat van het reïntegratieproces.

De kern van het onderzoek verricht in het kader van dit proefschrift, is dat wordt onderzocht in welke mate de genoemde langdurige (om)scholingstrajecten leiden tot succesvolle reïntegratie, waarbij als outputvariabelen zijn genomen, de persoonlijke ontwikkeling van de cursist, plaatsing in een functie die aansluit bij het gevolgde traject en het functioneren in de werksituatie. 
De eerste drie onderzoeksvragen van dit proefschrift hebben een beschrijvend karakter. Het betreft vragen die betrekking hebben op de persoonsgebonden factoren van de cursistenpopulatie, de inhoud en vormgeving van de REA-scholingscentra en de plaatsingsresultaten:

1. Wat zijn de kenmerken van de cursistenpopulatie, i.c. de persoonsgebonden factoren?

2. Hoe wordt het scholingsprogramma zoals toegepast door de REAscholingscentra, vormgegeven?

3. In hoeverre leidt het volgen van een langdurig scholingsprogramma tot succes, geconcretiseerd in een toename in de persoonlijke ontwikkeling, plaatsing op de reguliere arbeidsmarkt en succesvol functioneren in de werksituatie?

Deze vragen zullen worden beantwoord in de hoofdstukken 4 en 5 .

Vervolgens zal worden onderzocht in hoeverre het succes van de langdurige scholingstrajecten wordt beìnvloed door persoonsgebonden factoren, door specifieke kenmerken van het scholingsprogramma, door bedrijfsgebonden kenmerken, dan wel door de interactie tussen de genoemde kenmerken. Teneinde een beter inzicht te krijgen in de mate waarin eventuele effecten worden veroorzaakt door centrumspecifieke persoonsgebonden factoren en/of de specifieke elementen binnen de scholingsprogramma's, zullen bij de beantwoording van de onderzoeksvragen, daar waar mogelijk de analyses ook op centrumniveau worden uitgevoerd. Inzicht hierin leidt enerzijds tot handvatten voor toekomstig beleid ten aanzien van de reïntegratie van personen met een arbeidsongeschiktheidsuitkering, anderzijds kan het bestaande scholingsprogramma hierdoor meer worden toegespitst op individuele kenmerken van de te reïntegreren personen met een arbeidsongeschiktheidsuitkering en daardoor worden geoptimaliseerd.

Meer specifiek leidt dit tot de volgende vraagstellingen:

4. In welke mate blijken persoonsgebonden factoren bij te dragen aan het resultaat van het scholingsprogramma. zijnde een toename in de persoonlijke ontwikkeling, plaatsing op de reguliere arbeidsmarkt en succesvol functioneren in de werksituatie? 
5. In welke mate dragen de verschillende elementen van het scholingsprogramma, namelijk de vaktheoretische component en de begeleidings- en ondersteuningscomponent, bij aan het resultaat van het scholingsprogramma, zijnde een toename in de persoonlijke ontwikkeling, plaatsing op de reguliere arbeidsmarkt en succesvol functioneren in de werksituatie?

6. In welke mate blijken bedrijfsgebonden kenmerken bij te dragen aan het resultaat van het scholingsprogramma, zijnde plaatsing op de reguliere arbeidsmarkt en succesvol functioneren in de werksituatie?

Een antwoord op deze vragen wordt gegeven in hoofdstuk 6. 



\section{METHODEN VAN ONDERZOEK}

\subsection{INLEIDING}

Uit een inventarisatie van centra in Nederland die zich bezighouden met activiteiten op het gebied van reintegratie, blijken ten tijde van het hier beschreven onderzoek alleen de vijf genoemde REA-centra zich op een structurele wijze bezig te houden met langdurige reïntegratieprogramma's voor personen met beperkingen (Collijn, van Lierop \& Nijhuis, 1996). De cursisten van deze vijf centra vormen derhalve in de bestudeerde periode - zijnde de periode voorafgaande aan de privatisering - de gehele populatic personen met een arbeidsongeschiktheidsuitkering in Nederland waarvoor gerichte reïntegratie activiteiten zijn ondernomen in de vorm van een scholings- en begeleidingsprogramma. In die zin kan worden gesproken van een populatiestudie. Een deel van deze totale populatie, namelijk alle cursisten die in de periode ' 88 - '95 een opleiding volgen, zijn betrokken bij de beantwoording van de in dit proefschrift behandelde centrale vraagstelling:

In hoeverre leidt het volgen van een (om)scholingstraject tot reïntegratie en daarmee tot een uitstroom uit de WAO?

In dit hoofdstuk wordt een beschrijving gegeven van de wijze waarop de onderzoeksvragen (zie paragraaf 2.7) worden beantwoord. In eerste instantie wordt het object van onderzoek beschreven alsmede de procedure voor de benadering van de onderzoekspopulatie (paragraaf 3.2). Vervolgens wordt ingegaan op de aard en het type onderzoek (paragraaf 3.3) en worden de factoren beschreven die in dit onderzoek zijn meegenomen (paragraaf 3.4). Tenslotte zal de wijze van analyse worden beschreven (paragraaf 3.5 ).

\subsection{OBJECT VAN ONDERZOEK EN ONDERZOEKSPOPULATIE}

Het centrale object in deze studie vormen de scholingsprogramma's van de vijf eerder genoemde reïntegratiecentra. De groep cursisten van deze reìntegratiecentra vormt de totale populatie personen met een arbeidsongeschiktheidsuitkering die, voorafgaande aan het onderzoek. een (langdurig) scholingsprogramma heeft gevolgd. Daarmee 
omvat het onderzoek zowel de breedte van de individuele variantie als van de institutionele variantie (verschillende centra). Hierdoor wordt de representativiteit en de generaliseerbaarheid van de uitspraken aanmerkelijk vergroot. Door de vijf reïntegratiecentra in de beschrijving en de analyses zowel per centrum te beschrijven als deze te beschouwen als een geheel, kan inzicht worden verkregen in hoeverre specifieke elementen binnen de centra bepalend voor het resultaat.

\subsubsection{Procedure en onderzoekspopulatie}

Om een eventueel effect van de scholingsprogramma's of van de verschillen tussen de centra te kunnen begrijpen is het noodzakelijk om inzicht te hebben in de inhoud en vormgeving van de te onderscheiden scholingsprogramma's. Daartoe zijn interviews gehouden met professionals van de diverse centra. Teneinde gegevens omtrent de mate van participatie te verzamelen is een telefonische survey gehouden onder een selectie van oud-cursisten van de reïntegratiecentra, die tenminste twee jaar voorafgaande aan het onderzoek hun opleiding hebben afgerond. Specifieke gegevens omtrent de aanstellingsprocedure en het functioneren in de werksituatie zijn verzameld door middel van gestructureerde diepte-interviews met werkgevers/leidinggevenden van gereīntegreerde oud-cursisten. In die zin is in het hier beschreven onderzoek sprake van drie onderzoekspopulaties, namelijk de professionals, de cursisten en werkgevers/leidinggevenden (zie ook tabel 3.7, pagina 74-75).

In het hiernavolgende zullen de gevolgde procedures en onderzoekspopulaties achtereenvolgens worden beschreven.

\section{Professionals: procedure en populatie}

Door middel van een brief, waarin de aard en het belang van het onderzoek wordt aangegeven, zijjn de coördinatoren assessment, directeuren reïntegratiecentra, hoofden van opleidingsrichtingen, begeleiding en bemiddeling benaderd om hun medewerking te verlenen aan het onderzoek in de vorm van het deelnemen aan een individueel diepte-interview. Alle hiervoor benaderde personen blijken bereid hun medewerking te verlenen.

Eveneens door middel van een brief alsmede een mondelinge ondersteuning door de directeuren van de centra zijn in ieder centrum ongeveer vijf docenten benaderd om hun medewerking te verlenen aan het onderzoek. In enkele gevallen blijken docenten weliswaar hun medewerking te willen verlenen, maar door ziekte verhinderd zijn deel te nemen. Bij alle vijf reîntegratiecentra zijn focusgroep interviews met minimaal vier docenten gehouden. 


\section{Cursisten: procedure en onderzoekspopulatie}

Basis voor het in dit proefschrift beschreven onderzoek vormt de totale populatie cursisten die een scholingstraject heeft doorlopen bij een van de vijf genoemde reïntegratiecentra.

Alle oud-cursisten waarvan het adres kan worden achterhaald zijn door middel van een brief geïnformeerd over de enquête en het belang van hun medewerking daaraan. Bij de brief zit een toelichting waarin de inhoud van de enquête kort wordt beschreven. Eveneens toegevoegd is een antwoordformulier met portvrije antwoordenveloppe. Op het antwoordformulier kan ook worden aangegeven dat men niet benaderd wenst te worden.

In de referentie periode hebben 835 personen een scholingsprogramma afgerond. Negen oud-cursisten zijn inmiddels overleden. Van 740 van de resterende oudcursisten zijn adressen en telefoonnummers achterhaald. Achteraf blijken 42 adressen toch onbruikbaar. De 'bereikbare' groep oud-cursisten bestaat derhalve uit 698 personen.

In totaal sturen 141 personen het antwoordformulier terug met de mededeling dat men niet wenst mee te werken aan de enquête. Tijdens de telefonische enquête weigeren 12 personen alsnog hun deelname, 31 personen blijken niet bereikbaar ondanks herhaalde (10) pogingen.

In totaal worden 504 oud-cursisten telefonisch geënquêteerd. De respons bedraagt, uitgaande van de groep waarvan het adres beschikbaar is, $72.2 \%$.

Teneinde vast te kunnen stellen in hoeverre de onderzoeksgroep overeenkomt met de niet deelnemers, is de onderzoeksgroep vergeleken met de cursisten die niet deelnemen aan de telefonische survey tengevolge van onbereikbaarheid, non-respons en het niet voldoen aan de inclusiecriteria (minimaal twee jaar geleden een scholing afgerond hebbende). Deze beide groepen zijn vergeleken met betrekking tot leeftijd, geslacht, opleidingsniveau en arbeidsverleden (tabellen 3.1 en 3.2). Voor wat betreft de onderzochte variabelen blijkt geen verschil te bestaan tussen de deelnemers aan de telefonische survey en de niet deelnemers.

Tabel 3.1 Vergelijk deelnemers enquête - niet deelnemers; geslacht en arbeidsverleden $(\mathrm{n}=1092)$

\begin{tabular}{|c|c|c|c|c|c|c|c|c|}
\hline \multirow[b]{3}{*}{ Deelnemers $n=504$} & \multicolumn{4}{|c|}{ Geslacht' } & \multicolumn{4}{|c|}{ Arbeidsverleden } \\
\hline & \multicolumn{2}{|l|}{ Man } & \multicolumn{2}{|c|}{ Vrouw } & \multicolumn{2}{|c|}{ Gewerkt } & \multicolumn{2}{|c|}{ Niet gewerkt } \\
\hline & 391 & $78 \%$ & 113 & $22 \%$ & 320 & $63 \%$ & 184 & $37 \%$ \\
\hline Niet-deeinemers $n=588$ & 429 & $74 \%$ & 149 & $26 \%$ & 393 & $68 \%$ & 195 & $32 \%$ \\
\hline
\end{tabular}

Missing value $=10$ 


\begin{tabular}{|c|c|c|c|c|c|c|c|c|c|}
\hline \multirow[b]{3}{*}{ Deelnemers $n=504$} & \multicolumn{8}{|c|}{ Opleidingsniveau' } & \multirow{2}{*}{ Leeftijd (s.d.) } \\
\hline & \multicolumn{2}{|c|}{ VBO } & \multicolumn{2}{|c|}{ MAVO } & \multicolumn{2}{|c|}{$\begin{array}{l}\mathrm{MBO} / \\
\mathrm{HAVO} / \mathrm{VWO}\end{array}$} & \multicolumn{2}{|c|}{$\mathrm{HBO} / \mathrm{WO}$} & \\
\hline & 220 & $47 \%$ & 105 & $22 \%$ & 123 & $26 \%$ & 26 & $5 \%$ & $27.7(7.9)$ \\
\hline Niet-deelnemers $n=588$ & 297 & $52 \%$ & 111 & $19 \%$ & 128 & $23 \%$ & 32 & $6 \%$ & $28.7(8.0)$ \\
\hline
\end{tabular}

Missing value $=50$

\section{Werkgevers/leidinggevenden: procedure en onderzoekspopulatie}

Het basisbestand voor het werkgeversonderzoek vormen alle personen die zijn geënquêteerd en een scholingsprogramma hebben gevolgd aan de centra Sonneheerdt, Werkenrode, Hoensbroeck of Heliomare'. Alle respondenten hebben na afloop van het onderzoek een verkorte versie van de resultaten toegestuurd gekregen, alsmede een formulier waarin wordt gevraagd hun medewerking te verlenen aan een vervolgonderaook. De medewerking bestaat uit het vertenen van toestemming aan de onderzoekers om contact op te nemen met de huidige werkgever. Indien de werknemer hierop positief reageert, worden de werkgevers benaderd of zij bereid zijn mee te werken aan een onderzoek inzake genoemde gereìntegreerde werknemer. Gezien de kwalitatieve benadering kan worden volstaan met twintig tot dertig cases per centrum (Maso, 1989). Indien het aantal respondenten meer dan dertig bedraagt, zal random selectic plaatsvinden.

In totaal hebben 274 oud-cursisten het formulier teruggestuurd. Van deze groep blijken 160 oud-cursisten om diverse redenen hun medewerking niet te willen verlenen. Ongeveer $22 \%$ ( 59 van de 274 ) van de respondenten geeft aan geen medewerking te kunnen verlenen aan het onderzoek omdat ze op dat moment geen werk hebben, hetgeen overeenkomt met het verwachtte aantal werkloze oud-cursisten. Bijna $10 \%$ van de oud-cursisten is van mening dat het onderzoek bij hun werkgever geen zin heeft, aangezien het huidige werk volgens hen niet aansluit bij het door hen gevolgde scholings- en begeleidingstraject. Andere redenen die worden genoemd hebben betrekking op het niet willen lastig vallen van hun leidinggevenden, privacy, dan wel niet meer te willen worden geconfronteerd met de opleidingsperiode (tabel 3.3).

Het reintegratiecentrum EEGA heeft aan dit onderzock nict deetgenomen. 
Tabel 3.3 Overzicht redenen om geen medewerking te verlenen aan een vervolgonderzoek onder werkgevers ( $\mathrm{n}=160)$, Aantallen

Redenen

De oud-cursist heeft ten tijde van de vraag geen werk

Er bestaat geen aansluiting tussen het huidige werk en de gevolgde opleiding. De oud-cursist verricht nu ander werk dan waarvoor opgeleid

Er bestaat geen aansluiting tussen het huidige werk en de gevolgde opleiding. De oud-cursist heef na opleiding nog andere opleidingen gevolgd en daarin werk verkregen

Volgens de oud-cursist wil de werkgever niet meewerken

(geen zin of geen tijd)

De oud-cursist geeft aan het contact met de werkgever zinloos te vinden (werkgever kent reintegratie centra niet of heeft volgens de werknemer geen inzicht in zijn/haar taken)

De oud-cursist wil de werkgever niet lastig vallen

De oud-eursist wil niet worden geconfronteerd met de opleiding of de opleidingsperiode

De oud-cursist is erg gesteld op zijn/haar privacy

Geen reden

In totaal hebben 114 oud-cursisten toestemming gegeven hun werkgever te benaderen. Van deze groep werkgevers blijken uiteindelijk 75 werkgevers bereid mee te willen werken aan het vervolgonderzoek. Achttien werkgevers geven geen reden op waarom ze niet willen meewerken, eenentwintig werkgevers geven aan niet mee te werken omdat ze hiervoor geen tijd hebben. Uitgaande van de werknemers die toestemming geven hun werkgever te benaderen, betreft de respons onder werkgevers $66 \%$.

Om te kunnen vaststellen in hoeverre de cursisten, waarvan de werkgever wordt benaderd, overeenkomen met de resterende groep geënquêteerden, zijn beide met elkaar vergeleken met betrekking tot leeftijd, geslacht, opleidingsniveau en arbeidsverleden (tabellen 3.4 en 3.5). Voor wat betreft de onderzochte variabelen blijkt geen verschil te bestaan tussen de oud-cursisten waarvan de werkgevers zijn geïnterviewd en de andere deelnemers aan de telefonische survey.

Tabel 3.4 Vergelijking deeinemers interview werkgevers - niet deelnemers $(n=504)$

\begin{tabular}{lrlllllll}
\hline & \multicolumn{5}{c}{ Geslacht } & \multicolumn{3}{c}{ Arbeidsverleden } \\
\hline & Man & Vrouw & Gewerkt & Niet gewerkt \\
\hline Deelnemers $n=75$ & 53 & $71 \%$ & 22 & $29 \%$ & 45 & $60 \%$ & 30 & $40 \%$ \\
Niet-deelnemers $n=429$ & 338 & $78 \%$ & 91 & $22 \%$ & 275 & $64 \%$ & 154 & $36 \%$ \\
\hline
\end{tabular}




\begin{tabular}{lccccccccc}
\hline \multicolumn{1}{c}{ Tabel 3.5 Vergelijking deelnemers interviews werkgevers - niet deelnemers ( $\mathrm{n}=504)$} \\
\hline \multicolumn{1}{c}{ Opleidingsniveau' } \\
\hline \\
\hline
\end{tabular}

\section{Selectiebias}

De kans bestaat dat uitsluitend oud-cursisten die tevreden zijn over hun arbeidsplek en hun eigen functioneren, toestemming hebben gegeven aan de onderzoeker om hun werkgever te mogen benaderen. Gezien het verplichtende karakter van deze te doorlopen procedure, kon dit op geen enkele wijze worden voorkomen. In de discussie zal worden ingegaan in hoeverre dit mogelijk heeft geleid tot een verstoring van de resultaten.

\subsection{AARD EN TYPE ONDERZOEK}

In dit onderzoek wordt een antwoord gezocht op de vraag in hoeverre een specifieke vorm van interventie, namelijk een scholingstraject, succesvol is, c.q. bijdraagt aan een vergroting van de uitstroom uit de WAO. Enerzijds is dus sprake van een beschrijvend onderzoek, anderzijds wordt nagegaan - door middel van het onderzoeken van de relatie tussen de diverse onafhankelijke en afhankelijke variabelen - welke factoren verklarend zijn voor succes. Het beschrijvende deel van het onderzoek heeft betrekking op het in kaart brengen van de persoonsgebonden variabelen, de vormgeving van het reïntegratietraject, het plaatsingsproces en het functioneren in de werksituatie. Het betreft de beantwoording van de onderzoeksvragen 1, 2 en 3 . Het verklarende deel heeft betrekking op het onderzoeken van de verbanden tussen persoonlijke factoren, externe factoren en de mate van participatie. Het betreft de beantwoording van de onderzoeksvragen 4 tot en met 6 .

De gegevens omtrent persoonsgebonden factoren zijn verzameld door middel van een dossierstudie. Het betreft de dossiers van alle cursisten die in de periode 1988 - 1995 een scholingsprogramma hebben gevolgd bij een van de vijf centra. Gegevens omtrent de vormgeving van het reïntegratietraject zijn op vier verschillende wijzen verzameld. namelijk een documentenstudie, schriftelijke vragenlijsten, interviews (individuele diepte-interviews en focusgroep-interviews) en een telefonische survey. Gegevens over 
het plaatsingsproces zijn vervolgens verzameld door middel van een telefonische survey. Tenslotte zijn gegevens omtrent bedrijfsgebonden factoren en het functioneren in de werksituatie verzameld door middel van gestructureerde diepte-interviews (zie paragraaf 3.4). Door het gebruik van kwalitatieve data in dit onderzoek is getracht een dieper inzicht te verkrijgen in de ervaringen en onderliggende processen die hebben geleid tot de bereikte mate van participatie van personen met een arbeidsongeschiktheidsuitkering die een scholingsprogramma hebben doorlopen (Maso, 1989; Polit en Hungler, 1999).

Het betreft een cross-sectioneel onderzoek, waarbij gedeeltelijk gebruik wordt gemaakt van retrospectie. De interviews alsmede de schriftelijke vragenlijst hebben betrekking op de situatie van het moment van vragen, de telefonische survey vraagt deels naar de momentane situatie, deels naar ervaringen in het verleden opgedaan.

\section{Generaliseerbaarheid}

Van belang in dit onderzoek is de vraag in hoeverre de resultaten van het onderzoek generaliseerbaar zijn naar andere scholingsprogramma's voor arbeidsgehandicapten. Het eerste punt daarbij is dat het een populatiestudie betreft van iedere arbeidsgehandicapte die geparticipeerd heeft aan een scholingsprogramma. Er zijn geen redenen om te veronderstellen dat onderzoek onder andere arbeidsgehandicapten die een dergelijk langdurig traject volgen, andere resultaten zal vertonen. Een tweede element is de diversiteit van de scholingsprogramma's. Door de centra afzonderlijk te analyseren is het mogelijk om te bekijken of de verschillende scholingsprogramma's die door de vijf centra worden aangeboden, tot verschillende resultaten leiden. Indien de resultaten uitwijzen dat de vijf centra geen substantiele verschillen in resultaten opleveren, betekent dit dat niet zozeer de specificiteit van het programma, maar (de intensiviteit van) het scholingsprogramma meer bepalend is. Een derde element is het bovenregionale karakter van de centra; drie van de vijf centra hebben een landelijke functie. Een vierde element is de veelheid van gebruikte methoden, waardoor problemen met betrekking tot methodevariantie ten dele worden ondervangen. Het gebruik van een objectieve outputvariabele als onafhankelijke variabele, voorkomt dat een vorm van systematische positieve of negatieve vertekening op kan treden. Een vijfde element is dat naast objectieve criteria ook gekozen is voor meerdere respondenten, waardoor sprake is kruisvalidatie en triangulatic.

Op basis van bovenbeschreven elementen kan worden geconcludeerd dat de resultaten van deze studie generaliseerbaar zijn naar vergelijkbare scholingsprogramma's voor arbeidsgehandicapten. 


\section{HALO-effect}

Een probleem in veel survey onderzoek is dat de afhankelijke en onafhankelijke variabelen door middel van eenzelfde methodiek worden gemeten. Hierdoor kan sprake zijn van een vorm van HALO-effect; de positieve beoordeling van enkele specifieke aspecten kan een positieve uitstraling hebben naar andere gemeten aspecten (zie onder meer Nijhuis, 1984).

In dit onderzoek is getracht om een dergelijk effect op te vangen door gebruik te maken van objectieve gegevens met betrekking tot plaatsing en van het werkgeversoordeel over onder meer het functioneren in de werksituatie, het aannameproces, de benodigde aanpassingen en dergelijke. De gegevens met betrekking tot het scholingsprogramma zijn verkregen door zowel gebruik te maken van gegevens afkomstig van documenten, diepte-interviews en focusgroep-interviews met professionals, focusgroep-interviews met cursisten als door middel van vragen in de telefonische survey onder oud-cursisten. Er is dus gebruik gemaakt van verschillende informatiebronnen.

\section{Onderzoeksdesign}

Het feit dat de gegevens door middel van een eenmalige meting zijn verzameld, betekent dat het in kaart brengen van het reïntegratieproces gedeeltelijk plaatsvindt op basis van retrospectic. Retrospectief onderzoek draagt in haar hoedanigheid altijd een bepaalde mate van subjectiviteit in zich; zaken die zich in het verleden hebben voorgedaan, kunnen worden gekleurd door ontwikkelingen die vervolgens hebben plaatsgevonden, zaken ten tijde van de vraagstelling kunnen anders worden geînterpreteerd dan destijds het geval was (Munhall \& Boyd, 1993) dan wel kunnen de respondenten bepaalde zaken niet meer herinneren (recall-bias). Door gebruik te maken van diverse informatiebronnen en zowel objectieve gegevens als subjectieve gegevens met elkaar te combineren, alsmede de respondenten voor te bereiden op de survey door middel van een aankondigingsbrief met interviewtopics, is getracht om de nadelen van retrospectie gedeeltelijk op te vangen. Bovendien hebben de respondenten minimaal twee jaar voorafgaande aan de telefonische survey het scholingsprogramma afgerond, waardoor een relatief grote afstand tot het gevolgde scholingsprogramma wordt gecreëerd. 


\subsection{BESCHRIJVING FACTOREN}

\section{Persoonsgebonden factoren}

De gegevens over persoonsgebonden factoren zijn afkomstig uit de dossiers die bij de verschillende centra voor iedere cursist worden aangelegd. In een groot aantal dossiers ontbreekt informatie over de assessment, waardoor slechts in beperkte mate gegevens beschikbaar zijn over burgerlijke staat en woonsituatie, persoonlijkheid, sociale vaardigheden, intellectuele capaciteiten, mentale belastbaarheid, fysieke belastbaarheid, motorische vaardigheden en interesses, voorafgaande aan het scholingsprogramma en die voorspellend zouden kunnen zijn geweest voor succes. Daarnaast worden door de vijf centra niet altijd even consequent assessmentinstrumenten ingezet en worden in een aantal gevallen verschillende instrumenten ingezet voor het meten van dezelfde persoonsgebonden factoren. Door het ontbreken van gegevens en de mogelijke interpretatieverschillen bij gebruik van verschillende meetinstrumenten is opname in het analysemodel van deze persoonsgebonden factoren niet mogelijk. Onderzoek naar de assessmentgegevens met betrekking tot succes van het scholingsprogramma zoals dat in een van de centra heeft plaatsgevonden, heeft laten zien dat persoonlijkheidskenmerken geen voorspellende waarde hebben op toekomstig reîntegratie succes (Van Lierop \& Nijhuis, in prep.).

Voor het beschrijven van de cursistenpopulatie is derhalve gekozen voor de factoren leeftijd, geslacht, opleidingsniveau, arbeidsverleden en aandoeningen (en functionele beperkingen).

Het opleidingsniveau wordt vastgesteld aan de hand van de hoogst gevolgde opleiding voorafgaande aan het scholingsprogramma.

Voor het bepalen van het arbeidsverleden, i.c. een inventarisatie van de beroepen van de cursisten is gebruik gemaakt van de standaard beroepenclassificatie 1992 van het CBS (CBS,1993). In deze classificatie worden beroepen onderscheiden naar niveau (elementaire beroepen, lagere beroepen, middelbare beroepen, hogere beroepen en wetenschappelijke beroepen) en sector (bijvoorbeeld agrarisch, bouwkundig, technisch, administratief, etc.)

Het door de cursist laatste uitgeoefende beroep wordt beschreven naar niveau en sector. Indeling naar het aantal jaren dat de cursist werkzaam/niet werkzaam is, is door het ontbreken van dit soort gegevens in een groot aantal dossiers, niet mogelijk gebleken.

Wanneer het gaat om het begrip aandoening blijkt dit moeilijk te definiëren. In wezen kunnen twee benaderingen worden onderscheiden. Enerzijds de opvatting dat bij ziekte 
een persoon hoort met een geschiedenis en een plaats in de hem omringende wereld, die vervolgens in een code kan worden ondergebracht (bijvoorbeeld de ICIDH). Anderzijds kan de aandoening worden omschreven in termen van lichamelijke klachten, waarbij wordt uitgegaan van een revalidatieperspectief. Voor het classificeren van de aandoeningen van de in dit proefschrift beschreven cursistenpopulatie is, gezien de veelheid aan diagnoses, uitgegaan van een afgeleide van de indeling van Hanssen (1985). Hierbij wordt namelijk zowel gebruik gemaakt van medische diagnoses als van revalidatiegeneeskundige klachten, zoals bijvoorbeeld 'rugklachten'. Voor het classificeren van de lichamelijke beperkingen is uitgegaan van de door een aantal centra gehanteerde indeling van het CBS (Sonsbeek \& Verweij, 1991; NRV, 1994). De nadruk ligt hierbij op de functionele beperkingen die optreden vanuit de specifieke aandoening c.q. stoornis. Voor deze studie worden beperkingen ten aanzien van zitten/lopen, arm/handgebruik, zien, horen en spreken in kaart gebracht.

\section{Beschrijving programma}

Voor de beschrijving van het scholingsprogramma is gebruik gemaakt van semigestructureerde diepte-interviews met professionals werkzaam bij de reïntegratiecentra, een schriftelijke vragenlijst voor een deel van de geïnterviewde professionals en de cursistendossiers. Deze laatste zijn gebruikt om inzicht te krijgen in de individuele trajecten.

Uitgangspunt voor de in dit proefschrift gekozen methode van beschrijving van het curriculum vormt de wijze waarop visitatiecommissies de curricula van middelbare beroepsopleidingen beoordelen.

De coördinatoren van het assessment-gedeelte zijn geïnterviewd om inzicht te krijgen in de betrokken disciplines bij de assessmentprocedure, de vaste onderdelen van de assessment, eventuele toevoegingen, de beslissingsprocedure, opleidingsplan en instroom op de opleiding.

Gestructureerde diepte-interviews zijn gehouden met de hoofden van de reìntegratiecentra. De vragen hebben met name betrekking op de inhoud en organisatie van het curriculum alsmede op de kosten van de scholingsprogramma's.

De hoofden van het begeleidings- en ondersteuningsgedeelte van de scholingsprogramma's zijn eveneens uitvoerig geïnterviewd. De vragen met betrekking tot de begeleiding richten zich op de inhoud en organisatie van de verschillende vormen van begeleiding (begeleiding bij persoonlijke problemen, studiebegeleiding, psychosociale begeleiding en (para)medische begeleiding). Met de hoofden bemiddeling is gesproken over arbeidsbemiddeling, afstemming van de opleiding op de arbeidsmarkt, relatieonderhoud en nazorg voor cursisten die de opleiding reeds hebben afgerond. Tijdens 
de focusgroep interviews met de hoofden van de vakrichtingen en de begeleidingsmedewerkers is gesproken over doelstellingen en het realiseren van de doelstellingen en in hoeverre men de hiervoor benodigde zaken binnen bereik heeft. Daarnaast is gesproken over de inhoud en vormgeving van de opleidingen.

De schriftelijke vragenlijst is voorgelegd aan de hoofden van de vakrichtingen en de begeleidingsmedewerkers. De vragen hebben betrekking op de inhoud en het doel van hun vakrichting/begeleidingsvorm, de verdeling theorie en praktijk alsmede de gehanteerde werk-, instructie- en toetsvormen.

De door de professionals beschreven inhoud en organisatie van het scholingsprogramma is vervolgens getoetst aan de voorwaarden voor een succesvol scholingsprogramma, zoals die in de literatuur (zie hoofdstuk 2) worden beschreven.

In de cursisten dossiers blijkt informatie over de individuele scholingsprogramma's die door de oud-cursisten zijn gevolgd grotendeels te ontbreken. Uitgezonderd gegevens over de vakrichting kan uit de dossiers niet worden afgeleid in hoeverre en in welke mate oud-cursisten gebruik hebben gemaakt van bijvoorbeeld aangepaste lesprogramma's en/of individuele begeleiding en ondersteuning. Hierdoor is het niet mogelijk de individuele programma's van de oud-cursisten mee te nemen in de analyse. Door hierover vragen te stellen in de telefonische survey is getracht deze omissie op te lossen. Het betreft echter subjectieve informatie in tegenstelling tot de objectieve informatie die via de dossiers zou kunnen worden verzameld.

\section{Waardering scholingsprogramma}

Bij de oud-cursisten (zie hiervoor procedure en onderzoekspopulatie) heeft een telefonische survey plaatsgevonden teneinde inzicht te krijgen in de waardering voor het scholingsprogramma c.q. de aansluiting van het scholingsprogramma op de persoonlijke behoeften en capaciteiten van de oud-cursisten. Door middel van de telefonische survey dient tevens inzicht verkregen te worden in de persoonlijke ontwikkeling van de oud-cursisten en de arbeidsparticipatie op de korte en lange termijn. De telefonische survey is afgenomen door vooraf getrainde en geĭnstrueerde enquêtrices van het MEMIC, een facilitaire dienst binnen de Universiteit Maastricht.

Op basis van de in de hoofdstuk 2 beschreven scholingsgebonden factoren van invloed op succesvolle reïntegratic. de diepte-interviews met professionals en de eerder genoemde procedure voor visitatie van middelbare beroepsopleidingen, zijn de onderwerpen inzake de waardering van, c.q. de mate van tevredenheid over het scholingsprogramma vastgesteld. Hierbij is uitgegaan van het disconfirmatieparadigma van Oliver (1980). Wanneer het scholingsprogramma voldoet aan voorafgestelde verwachtingen (confirmatie), is de cursist niet ontevreden maar ook niet tevreden. Pas 
wanneer het scholingsprogramma niet overeenkomt met de verwachtingen van de cursist, ontstaat een ontevredenheid of juist een tevredenheid (disconfirmatie). Aan de oud-cursisten is gevraagd naar de mening over de inhoud, het tempo en het niveau van het educatieve gedeelte binnen het scholingsprogramma. Aan de orde komen de theoretische en praktische vorming binnen de vaktheoretische component, de kwaliteit van het lesmateriaal, het niveau en tempo van het scholingsprogramma, de didactische kwaliteiten van de docenten en de diverse vormen van begeleiding, i.c. de begeleiding tijdens lessen, de studiebegeleiding en de begeleiding bij persoonlijke problemen. Voor alle genoemde componenten is de tevredenheid gemeten door middel van stellingen, waarop met behulp van een vijfpuntsschaal de mate van tevredenheid kan worden aangegeven ( $1=$ helemaal mee eens, $5=$ helemaal mee oneens).

Ten aanzien van het begeleidingsgedeelte binnen het scholingsprogramma is gevraagd naar de mening inzake de begeleiding bij persoonlijke problemen, de specifieke psychosociale begeleiding en de (para)medische begeleiding. Ten behoeve van deze genoemde componenten zijn eveneens stellingen geformuleerd waarop met behulp van een vijfpuntsschaal kan worden geantwoord $(1=$ helemaal mee eens, $5=$ helemaal mee oneens).

Tenslotte is geìnformeerd naar de door de oud-cursist ervaren bijdrage van de verschillende scholingscomponenten aan een goede voorbereiding op de arbeidsmarkt, namelijk de bijdrage van het vakgericht theoretisch gedeelte, van het vakgericht praktijkgedeelte, van de beroepsgerichte trainingen, van de begeleiding bij het vinden van een baan alsmede van de ondersteuning door het scholingscentrum na het scholingsprogramma. Hiervoor zijn stellingen geformuleerd. waarop met een vierpuntsschaal kan worden geantwoord ( $1=$ veel bijgedragen, $4=$ niet bijgedragen).

\section{Persoonlijke ontwikkeling}

De mate waarin een persoon kan participeren in de maatschappij, en meer specifiek op de arbeidsmarkt, is onder meer afhankelijk van de mate waarin een persoon denkt in staat te zijn arbeid te kunnen verrichten, c.q. de beoordeling van de eigen effectiviteit met betrekking tot het verrichten van arbeid (Bandura, 1986). De eigen effectiviteit wordt zowel bepaald door de ingeschatte vakmatige vaardigheden, als door factoren op psycho-sociaal gebied. Vanwege het door de persoon met een arbeidsongeschiktheidsuitkering ervaren medicaliseringsproces (zie hoofdstuk 1), kan worden gesproken over een lage eigen effectiviteit ten aanzien van het verrichten van arbeid. In hoeverre hier een ontwikkeling heeft plaatsgevonden kan, gezien het karakter van het onderzoek (cross-sectioneel onderzoek) alleen worden bevraagd door middel van een retrospectieve zelfrapportage vergelijking. In de telefonische survey voor de oud- 
cursisten is gevraagd in hoeverre naar hun idee het scholingsprogramma heeft bijgedragen aan een toegenomen persoonlijke ontwikkeling, waarbij worden onderscheiden een toegenomen zelfvertrouwen, het beter kunnen omgaan met hun ziekte/beperking, betere sociale vaardigheden, een groter incasseringsvermogen en een beter functioneren op de arbeidsmarkt. Het betreft items die deels zijn gebaseerd op de literatuur, deels zijn gebaseerd op de interviews met de professionals en op de focusinterviews met de oud-cursisten. Voor elke component zijn stellingen geformuleerd, waarop met behulp van een vijfpuntsschaal kan worden geantwoord ( $1=$ helemaal mee eens, $5=$ helemaal niet mee eens).

Tabel 3.6 geeft een overzicht van de onderlinge correlaties tussen de variabelen binnen de factor persoonlijke ontwikkeling. Cursisten die aangeven een positieve ontwikkeling te hebben doorgemaakt ten aanzien van hun zelfvertrouwen, geven eveneens aan beter om te kunnen gaan met hun beperkingen, over betere sociale vaardigheden te beschikken, een groter incasseringsvermogen te hebben en beter te kunnen functioneren op de arbeidsmarkt, in vergelijking met de situatie voorafgaande aan het scholingsprogramma. Op basis van deze verbanden zijn de individuele variabelen (zelfvertrouwen, omgaan met beperkingen, sociale vaardigheden, incasseringsvermogen en functioneren) tot een schaal 'persoonlijke ontwikkeling' geconstrueerd $($ alpha $=0.75)$.

Tabel 3.6 Correlaties tussen de variabelen binnen de factor persoonlijke ontwikkeling : zelfvertrouwen, omgaan met beperkingen, sociale vaardigheden, incasseringsvermogen en functioneren op de arbeidsmarki $(\mathrm{n}=504)$

\begin{tabular}{|c|c|c|c|c|}
\hline & Zelfvertrouwen & $\begin{array}{l}\text { Omgaan met } \\
\text { beperkingen }\end{array}$ & $\begin{array}{l}\text { Sociale } \\
\text { vaardigheden }\end{array}$ & Incasseringsvermogen \\
\hline Omgaan met beperkingen & $48 \cdots$ & & & \\
\hline Sociale vaardigheden & $.43 \cdots$ & $.48 *$ & & \\
\hline Incasseringsvermogen & $40 *$ & $.39 *$ & $.52 *$ & \\
\hline Functioneren op arbeidsmarkt & $31 \%$ & $.32 \cdots$ & $27 * *$ & $.25 \cdots$ \\
\hline
\end{tabular}
$0.001<p \leq 0.01$

Gezien het belang van de individuele bijdrage van de variabelen binnen de schaal, zullen bij de analyses in een aantal gevallen zowel de individuele variabelen worden beschreven als de schaalconstructie. 


\section{Plaatsing}

Wanneer wordt gekeken naar de wijze waarop in eerder onderzoek plaatsingsresultaten worden beschreven (zie hoofdstuk 2), blijkt dat in vrijwel alle gevallen deze resultaten zich beperkingen tot het beschrijven van het percentage geplaatsten. Daarnaast vinden evaluaties van reïntegratieprogramma's meestal plaats binnen een half tot een jaar na afronding, hetgeen geen inzicht geeft in de plaatsingsresultaten op de lange termijn (Riipinen et al., 1994). Voor de vraagstelling van dit onderzoek vormen percentuele plaatsingsresultaten een indicatie voor succes, echter deze geven onvoldoende inzicht in hoeverre het scholingsprogramma heeft bijgedragen aan de plaatsingsresultaten. In die zin kunnen gegevens omtrent het aannameproces, de benodigde werkaanpassingen en de aansluiting met het scholingsprogramma méér inzicht geven in de mate waarin scholingsprogramma's bijdragen aan succesvolle reïntegratie. De keuze voor deze variabelen komt voort uit de werkwijze van de reïntegratiecentra, waarbij de cursisten een traject volgen in een vakrichting waarin de aanwezige beperkingen niet of nauwelijks een rol spelen, teneinde blijvende reïntegratie op de reguliere arbeidsmarkt te bevorderen.

In de telefonische survey is aan de oud-cursisten gevraagd of zij op korte termijn na afronding van het scholingsprogramma een baan hebben gevonden en of zij op de lange termijn nog steeds werkzaam zijn. Plaatsing op korte termijn is gedefinieerd als binnen twaalf maanden na afronding van het scholingsprogramma, op langere termijn is gedefinieerd als het vervullen van een plaats op de arbeidsmarkt op het moment van de survey, gemiddeld vijf jaar na afronding van het scholingsprogramma.

Gevraagd is op welke wijze de oud-cursisten de eerste baan hebben gevonden, waarbij de respondenten kunnen kiezen uit meerdere antwoordmogelijkheden (onder meer open sollicitatie, bemiddeling door derden, reguliere vacatures etc.). Hierbij is tevens gevraagd naar de aansluiting tussen de theoretische vorming en praktische vorming van het scholingsprogramma en de eerste baan (gesommeerd: alpha $=0.75$ ), dan wel de aansluiting van deze eerste baan met eerdere beroepservaring. Aan de werkende oud-cursisten is gevraagd in hoeverre ze van zichzelf vinden dat ze minder goed, gelijk of beter zijn opgeleid in vergelijking met collega's die soortgelijk werk verrichten. Vervolgens is geìnformeerd naar de vorm van het dienstverband, zelfstandig, loondienst etc. (meerdere antwoorden mogelijk), het soort dienstverband (vast onbepaald of tijdelijk bepaald) alsmede de actuele inkomens- en uitkeringspositie van de oud-cursisten. Voor de inkomsten is aangesloten bij het onderzoek onder WAOuitkeringsgerechtigden van Fiseler, Molenaar-Cox, Kers \& Van der Stelt (1993).

De gegevens met betrekking tot de uitkerings- en inkomenssituatie zijn voornamelijk gebruikt om vast te kunnen stellen in hoeverre de kosten van een scholingsprogramma 
opwegen tegen de baten, uitgedrukt in het vinden van betaald werk en derhalve een verminderd beroep op de sociale zekerheid.

Aan de werkenden is gevraagd naar eventuele aanpassingen van de werkapparatuur, meubilair, werktijden en/of ondersteuning van collega's. Daarnaast is geìnformeerd of zij beperkingen ondervinden in het uitoefenen van hun huidige beroep.

In het in het kader van dit proefschrift verricht onderzoek zijn, naast oud-cursisten, tevens werkgevers die gereīntegreerde werknemers in dienst hebben geìnterviewd (zie tevens 'functioneren in de werksituatie'). Een aantal vragen in deze interviews richt zich op het aanstellingsproces vanuit het oogpunt van de werkgever. Een vijftal vragen heeft betrekking op de procedure rondom de sollicitatie en aanname, namelijk de soort vacature en aanstelling, het aantal kandidaten waaruit is gekozen en de redenen voor aanname. Bij alle vragen zijn gesloten antwoordcategorieën geformuleerd, specifiek gericht op de vraag. Vervolgens wordt middels een zevental vragen geìnformeerd naar de bekendheid met en het gebruik van diverse instrumenten die kunnen worden ingezet bij de indienstneming van een persoon met een arbeidsongeschiktheidsverleden. De vragen richten zich op loonkostensubsidie, begeleidingssubsidie, job coaching, loondispensatie, loonvergoeding bij ziekte en vergoeding van aanpassingen. Indien geen gebruik is gemaakt van het instrument wordt gevraagd naar de redenen hiervoor.

Een vraag richt zich op de tijd die de aanname heeft gekost in vergelijking met vergelijkbare andere werknemers. Antwoordmogelijkheden zijn meer, minder, gelijk of niet van toepassing. Indien de aannameprocedure meer tijd heeft gekost, wordt geïnformeerd waarom dit het geval is en of de grotere tijdsinvestering volgens de geĭnterviewde de moeite waard is geweest.

Vragen aangaande de beperkingen van de gereïntegreerde werknemer richten zich op de bekendheid van de werkgever met de aanwezige beperkingen, of de toekomstige collega's zijn geînformeerd over de komst van een persoon met beperkingen en indien ja, op welke wijze deze informatie overdracht heeft plaatsgevonden (open antwoordmogelijkheid).

Bij de oud-cursisten die geen baan hebben op zowel korte als lange termijn is gevraagd naar de redenen hiervoor.

\section{Functioneren in de werksituatie}

De invulling van de factor 'functioneren in de werksituatie' wordt in dit onderzoek bepaald aan de hand van gestructureerde diepte-interviews met werkgevers/ leidinggevenden van gereïntegreerde oud-cursisten. Een onderzoek naar het daadwerkelijk functioneren in de werksituatie van personen met een arbeidsongeschiktheidsverleden is in Nederland nog niet eerder verricht en in die zin kan worden 
gesproken van een toevoeging aan de tot nu tot verrichte studies op het gebied van de reïntegratie van personen met een arbeidsongeschiktheidsverleden. Voor dit onderdeel van de hier beschreven studie zijn face to face interviews gehouden met werkgevers en leidinggevenden. De face to face interviews zijn op band opgenorren en nadien letterlijk uitgewerkt. Vervolgens zijn de antwoorden door diverse onderzoekers onafhankelijk van elkaar gescoord, teneinde een grotere betrouwbaarheid te bereiken. De letterlijke teksten zijn, zoals aangegeven, gesorteerd en worden in dit proefschrift regelmatig aangehaald teneinde de kwantitatieve gegevens te visualiseren.

Bij vragen over aanpassingen wordt een onderscheid gemaakt tussen aanpassingen op de werkplek, aanpassingen van het takenpakket, aanpassingen van de werktijden, overige aanpassingen. Gevraagd wordt in hoeverre aanpassingen nodig zijn en welke aanpassingen het betreft. De vragen over ondersteuning hebben betrekking op de ondersteuning door collega's.

De vragen die betrekking hebben op het algemeen en specifiek functioneren van de gereĭntegreerde werknemer betreffen vragen over de algemene arbeidsproductiviteit, de vakkennis, vaktechnische vaardigheden, sociale vaardigheden, de werkhouding, verzuim van de gereïntegreerde werknemer. Volgens de geïnterviewde werkgevers omvatten deze vragen de domeinen waarop werknemers worden gewaardeerd. De vragen hierover zijn opgesteld volgens een bepaalde systematiek. In eerste instantie wordt gevraagd of de gereintegreerde werknemer volgens de geînterviewde leidinggevende op een hoger, lager of gelijk niveau functioneert in vergelijking met vergelijkbare collega's als het gaat over bovengenoemde onderwerpen, of dat deze vraag niet van toepassing is, vanwege de onmogelijkheid van vergelijking. Indien wordt geantwoord dat de gereïntegreerde werknemer op een hoger of lager niveau functioneert, wordt door een open vraag geïnformeerd waaruit dit blijkt. In relatie met het algemeen en specifiek functioneren is gevraagd naar (vergelijkbare) doorgroeimogelijkheden binnen het bedrijf in het algemeen en specifiek voor de betreffende gereintegreerde werknemer. Vervolgens wordt gevraagd of en in hoeverre de aanstelling van de gereỉntegreerde werknemer de sfeer op de afdeling/binnen het bedrijf heeft beìnvloed. Tot slot is bij de leidinggevenden geïnformeerd naar hun mening betreffende beïnvloedende factoren voor succesvolle blijvende integratie van mensen met beperkingen.

\section{Bedrijfsgebonden factoren}

Zoals blijkt uit hoofdstuk 2 kunnen bedrijfsgebonden factoren, zoals grootte en type bedrijf en cultuur van het bedrijf, een rol spelen bij succesvolle reïntegratie. Derhalve zijn in het face to face interview met leidinggevenden vragen gesteld over 
respectievelijk de omvang van het bedrijf (aantal werknemers) en de sector waartoe het bedrijf behoort. Beide vragen hebben een open antwoordmogelijkheid. Ten aanzien van de cultuur van het bedrijf in relatie tot mensen met een arbeidsongeschiktheidsverleden, c.q. de visie van de leidinggevende op het aannemen van mensen met een arbeidsongeschiktheidsverleden, wordt gevraagd of de betreffende werkgever meerdere personen met een arbeidshandicap in dienst heeft en in hoeverre het bedrijf open staat om in de toekomst arbeidsgehandicapten in dienst te nemen.

Aangezien alleen gegevens bekend zijn over bedrijfsgrootte en bedrijfssector in relatie tot gereïntegreerde werknemers is het niet mogelijk een relatie te leggen met plaatsing. aansluiting opleidingsprogramma en aanpassingen in de werksituatic. Tussen bedrijfsgrootte en bedrijfssector enerzijds en de variabelen met betrekking tot het functioneren in de werksituatie anderzijds bestaat geen samenhang. Derhalve vervalt de zesde onderzoeksvraag. De beschrijving van de 'bedrijfsgebonden factoren' is in zijn geheel opgenomen in het 'plaatsingsgedeelte' (paragraaf 5.2).

\subsection{ANALYSE VRAAGSTELLINGEN}

De vraagstellingen 1 tot en met 3 hebben een beschrijvend karakter en zijn beantwoord met behulp van descriptieve statistiek. Alle variabelen die in tabel 3.7 zijn opgenomen, zijn op deze wijze verwerkt. Met betrekking tot de nominale en ordinale variabelen zijn frequenties berekend, waar met betrekking tot de ratio variabelen gemiddeldes (en standaarddeviaties) zijn bepaald. Voor vergelijking waarin nominale en ordinale variabelen zijn betrokken is gebruik gemaakt van chi-kwadraat toetsing, daar waar ratio variabelen zijn betrokken heeft vergelijking plaatsgevonden met behulp van ttoetsen. In de hoofdstukken 4 en 5 van dit proefschrift zijn de resultaten hiervan terug te vinden.

De vraagstellingen 4 en 5 hebben een verklarend karakter en zijn beantwoord met correlationele en multi-variate analyses. Een aantal variabelen is om statistische redenen (nominale variabelen, spreiding, respons) uitgesloten van deze analyses. De variabelen die in deze analyses wel zijn meegenomen zijn in de tabel 3.7 aangegeven met een asterix. Met betrekking tot de analyses waar de afhankelijke variabele een dichotome betreft, is gebruik gemaakt van logistische regressie, daar waar de afhankelijke variabele een ordinaal karakter heeft, is gebruik gemaakt van een multiple lineaire regressie. 


\section{Overzicht variabelen, onderzoekspopulatie en meetinstrumenten}

In tabel 3.7 wordt een overzicht gegeven van de verschillende factoren, de daarbij gemeten variabelen, de onderzoekspopulatie en de gehanteerde meetinstrumenten.

\begin{tabular}{|c|c|c|c|}
\hline Factor & Variabelen & Onderzockspopulatic & Mectinstrument \\
\hline $\begin{array}{l}\text { Persoons- } \\
\text { gebonden } \\
\text { factoren }\end{array}$ & $\begin{array}{l}\text { leeftijd* } \\
\text { geslacht* } \\
\text { werkervaring* } \\
\quad \text { niveau } \\
\quad \text { sector } \\
\text { hoogste opleiding* } \\
\text { aandoeningen } \\
\text { beperkingen } \\
\text { vakrichting }\end{array}$ & $\begin{array}{l}\text { Totale cursistenpopulatic } \\
\text { in de periode } \cdot 88-\cdot 95\end{array}$ & Dossierstudie \\
\hline $\begin{array}{l}\text { Beschrijving } \\
\text { scholings- } \\
\text { programma }\end{array}$ & $\begin{array}{l}\text { assessment } \\
\text { procedure } \\
\text { vaste onderdelen } \\
\text { toegevoegde onderdelen } \\
\text { betrokken disciplines } \\
\text { beslissingsprocedure } \\
\text { individueel reintegratieplan } \\
\text { instroomprocedure } \\
\text { vaktheoretische component } \\
\text { inhoud } \\
\text { organisatic } \\
\text { werkvormen } \\
\text { begeleidings- en ondersteuningscomponent } \\
\text { inhoud } \\
\text { organisatic } \\
\text { bemiddeling } \\
\text { arbeidsbemiddeling } \\
\text { afstemming opleiding op arbeidsmarkt } \\
\text { nazorg }\end{array}$ & $\begin{array}{l}\text { Professionals werkzaam } \\
\text { bij reintegratiecentra }\end{array}$ & $\begin{array}{l}\text { Schriftelijke vragenlijst } \\
\text { Semi-gestructureerde } \\
\text { diepte-interviews } \\
\text { Focusgroep interviews }\end{array}$ \\
\hline $\begin{array}{l}\text { Waardering } \\
\text { programma }\end{array}$ & $\begin{array}{l}\text { theoretische vorming* } \\
\text { praktische vorming* } \\
\text { kwaliteit lesmateriaal* } \\
\text { niveau scholingsprogramma* } \\
\text { tempo scholingsprogramma* } \\
\text { begeleiding tijdens onderwijs } \\
\text { didactische kwaliteiten docenten" } \\
\text { studiebegeleiding* } \\
\text { begeleiding bij persoonlijke problemen* }\end{array}$ & Populatic oud-cursisten & Telefonische survey \\
\hline $\begin{array}{l}\text { Persoonlijke } \\
\text { ontwikkeling }\end{array}$ & $\begin{array}{l}\text { selfvertrouwen" } \\
\text { omgaan met beperkingen* } \\
\text { contacteniomgaan met anderen* } \\
\text { incasseringsvermogen* } \\
\text { functioncren op de arbeidsmarkt* }\end{array}$ & Populatic oud-cursisten & Telefonische survey \\
\hline
\end{tabular}


Tabel 37

\section{Plaatsing}

unctioneren in de werksituatic aannameproces

soort vacature

aantal sollicitanten

wijze van aanname

redenen aanname

kennis van arbeidshandicap

kennistoepassing reintegratic

instrumenten

tijdsinvestering

betrokkenheid afdeling

informatievoorziening collega's

plaatsing korte termijn

werk binnen cen jaar*

aantal maanden na afronding werk

aansluiting baan eerdere beroepservaring

vergeliiking opleidingsniveau met

collega's

wijze van baan vinden

werkvorm

plaatsing lange termijn

werk op moment van survey*

soon dienstverband

uitkeringssituatic

inkornsten

ervaren beperkingen in de werksituatic

benodigde werkaanpassingen

aanpassingen van apparatuur ${ }^{*}$

aanpassingen van meubilair*

aanpassingen van werktijden*

ondersteuning van collega' $s^{*}$

aansluiting vaktheoretische vorming op baan* aansluiting baan theoretische vorming aansluiting baan praktische vorming

factoren inzake nict-succesvolle reintegratic

geregelde aanpassingen

aanpassingen van werkplek* aanpassingen van takenpakket* aanpassingen van werktijden* ondersteuning van collega's*

algemene productiviteit*

vakkennis*

vaktechnische vaardigheden*

sociale vaardigheden*

werkhouding*

verzuim*

doorgroeimogelijkheden

invloed aanstelling op sfeer afdeling

factoren inzake succesvolle blijvende integratic

Bedrijfsgebonden

factoren

grootte bedriif

type bedrij!

cultuur bedrijf

meerdere werknemers met

arbcidshandicap

aannamebeleid arbeidsgehandicapten

Populatic oud-cursisten

Telefonische survey

Werkgevers:

Ieidingevenden die

gereintegreerde

oud-cursisten in dienst

hebben

Werkgevers

leidingevevenden die gereintegreerde

oud-cursisten in dienst

hebben
Gestructureerde diepteinterviews
Gestructureerde diepte interview:
Werkgevers

leidingzevenden die

gereintegreerde

oud-cursisten in dienst

hebben
Gestructureende diepteinterviews 
Tenslotte is van belang aan te geven dat in dit onderzoek gegevens afkomstig van verschillende bronnen aan elkaar worden gekoppeld. Aan de oud-cursisten is toestemming gevraagd de dossiers in te zien en de werkgever te mogen benaderen. Tevens is gebruik gemaakt van unieke nummers, waardoor koppeling van gegevens mogelijk was zonder dat deze herleidbaar zijn tot persoonsniveau. 


\section{RESUltaten: SCHOLING}

\subsection{INLEIDING}

In dit hoofdstuk wordt antwoord gegeven op de eerste twee vraagstellingen, betrekking hebbende op de kenmerken van de cursistenpopulatie en de inhoud en werkwijze van de REA-centra, zijnde:

I Wat zijn de kenmerken van de cursistenpopulatie, i.c. de persoonsgebonden factoren?

2 Hoe wordt het scholingsprogramma zoals toegepast door de REAscholingscentra, vormgegeven?

In paragraaf 4.2 worden de kenmerken van de cursistenpopulatie beschreven. Vervolgens zal in paragraaf 4.3 het scholingsprogramma worden beschreven vanuit het perspectief van de professionals, waarna in paragraaf 4.4 het scholingsprogramma wordt geèvalueerd op basis van de eisen die vanuit de literatuur aan dergelijke scholingsprogramma's worden gesteld en vanuit het perspectief van de oud-cursisten.

\subsection{KENMERKEN CURSISTENPOPULATIE}

Personen die een scholingsprogramma aan een van de REA-centra volgen, worden gekenmerkt door een aantal gemeenschappelijke factoren. Het betreft in alle gevallen personen die een volledige arbeidsongeschiktheidsuitkering hebben, langdurig uit het arbeidsproces zijn of nog niet aan het arbeidsproces hebben declgenomen en, ten gevolge van een gezondheidsprobleem, een dusdanig grote afstand tot de arbeidsmarkt hebben dat reïntegratie via reguliere wegen niet (meer) tot de mogelijkheden behoort. Alle cursisten ervaren een of meerdere beperkingen vanwege een al dan niet objectiveerbare aandoening. Naast een aantal gemeenschappelijke kenmerken is sprake van een aantal specifieke persoonsgebonden kenmerken. In het hiernavolgende wordt een beschrijving gegeven van de specifieke karakteristicken van de cursistenpopulatic, namelijk de sociaal-demografische kenmerken leeftijd, sexe, opleidingsniveau, waarbij als referentie wordt genomen, de hoogst genoten opleiding die een cursist heeft 
genoten alvorens te starten met een scholingsprogramma, het arbeidsverleden van de cursisten (voor zover van toepassing) en tot slot de aandoeningen en beperkingen van de cursistenpopulatie.

\section{Demografische gegevens}

In de hiernavolgende tabel 4.1 wordt een overzicht gegeven van de variabelen leeftijd, geslacht, arbeidsverleden en hoogst gevolgde opleiding voorafgaande aan het scholingsprogramma van de cursisten van de vijf reïntegratiecentra.

De gemiddelde leeftijd bij aanvang van het reïntegratietraject is 28.2 jaar. De cursisten van Sonneheerdt en Werkenrode zijn ten opzichte van de andere drie reïntegratiecentra aanmerkelijk jonger ( $F=39,1, p<0,001)$. De gemiddelde leeftijd van de cursisten van Sonneheerdt en Werkenrode is gemiddeld 23 jaar en daarmee ongeveer zeven jaar lager dan die van de andere drie centra.

De cursisten zijn gemiddeld 17.2 jaar wanneer zij een eerdere opleiding hebben afgerond, hetgeen betekent dat de cursisten gemiddeld ruim tien jaar uit het

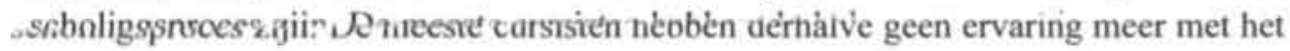
dagelijkse schoolritme. Een groot gedeelte van de cursisten heeft de tussenliggende tijd ingevuld met werken, dit geldt echter niet voor iedereen.

Tabel 4.1 Demografische gegevens cursisten. Gemiddelden, aantallen en percentages.

\begin{tabular}{|c|c|c|c|c|c|c|c|c|c|c|c|c|}
\hline & \multicolumn{2}{|c|}{$\begin{array}{l}\text { Totaal } \\
n=1092\end{array}$} & \multicolumn{2}{|c|}{$\begin{array}{l}\text { Hoensbroeck } \\
n=386\end{array}$} & \multicolumn{2}{|c|}{$\begin{array}{l}\text { Werkenrode } \\
n=113\end{array}$} & \multicolumn{2}{|c|}{$\begin{array}{l}\text { Sonncheerdt } \\
n=171\end{array}$} & \multicolumn{2}{|c|}{$\begin{array}{l}\text { Heliomare } \\
n=260\end{array}$} & \multicolumn{2}{|c|}{$\begin{array}{l}\text { EEGA } \\
n=162\end{array}$} \\
\hline Leeftijd' $\cdots$ & \multicolumn{2}{|c|}{$28.2(8.0)$} & \multicolumn{2}{|c|}{$30.0(6.8)$} & \multicolumn{2}{|c|}{$23.4(4.9)$} & \multicolumn{2}{|c|}{$22.9(6.2)$} & \multicolumn{2}{|c|}{$29.4(8.5)$} & \multicolumn{2}{|c|}{$31.2(9.0)$} \\
\hline \multicolumn{13}{|l|}{ Geslacht ${ }^{2} \cdots \bullet$} \\
\hline $\operatorname{man}$ & 819 & $76 \%$ & 352 & $91 \%$ & 86 & $76 \%$ & 125 & $73 \%$ & 165 & $64 \%$ & 91 & $58 \%$ \\
\hline vrouw & 263 & $24 \%$ & 33 & $9 \%$ & 27 & $24 \%$ & 46 & $27 \%$ & 91 & $36 \%$ & 66 & $42 \%$ \\
\hline \multicolumn{13}{|c|}{ Hoogste opleiding' «. } \\
\hline VBO & 517 & $50 \%$ & 202 & $54 \%$ & 71 & $63 \%$ & 67 & $39 \%$ & 140 & $60 \%$ & 37 & $24 \%$ \\
\hline MAVO & 216 & $21 \%$ & 79 & $21 \%$ & 32 & $29 \%$ & 62 & $37 \%$ & 38 & $16 \%$ & 5 & $3 \%$ \\
\hline MBO/HAVO/VWO & 251 & $24 \%$ & 80 & $21 \%$ & 9 & $8 \%$ & 34 & $20 \%$ & 45 & $20 \%$ & 83 & $55 \%$ \\
\hline $\mathrm{HBO} / \mathrm{WO}$ & 58 & $6 \%$ & 14 & $4 \%$ & & & 7 & $4 \%$ & 10 & $4 \%$ & 27 & $18 \%$ \\
\hline \multicolumn{13}{|l|}{ Arbeidsverleden $\cdots$} \\
\hline Ja & 713 & $65 \%$ & 346 & $90 \%$ & 52 & $46 \%$ & 42 & $25 \%$ & 168 & $65 \%$ & 105 & $65 \%$ \\
\hline Nee & 379 & $35 \%$ & 40 & $10 \%$ & 61 & $54 \%$ & 129 & $75 \%$ & 92 & $35 \%$ & 57 & $35 \%$ \\
\hline
\end{tabular}

Als peildatum voor de leeftijd is het startjaar gehanteerd

Missing Value $=10$

Missing Value $=50$

*. p $\leq 0.001$ 
Het aantal mannen dat een scholingsprogramma volgt is drie maal zo groot als het aantal vrouwen. In hoeverre deze verhouding overeenstemt met landelijke verhoudingen mannen en vrouwen in het voorbereidend en middelbaar beroepsonderwijs, is afhankelijk van de aangeboden vakrichtingen. Gezien het grote aanbod aan 'mannelijke vakken' (zie paragraaf 4.2 ), is een scheve verdeling niet vreemd (CBS, 1997). Wanneer op centrumniveau wordt gekeken kan de extreem scheve verdeling 'Hoensbroeckse' mannen en vrouwen niet worden verklaard door het vak aanbod $\left(\mathrm{chi}^{2}=86.9, \mathrm{p}<0.001\right)$. Evenmin kan deze verhouding worden verklaard door de verhouding man-vrouw in de WAO $(60 \%-40 \%)$. Concluderend kan worden gesteld dat er een ondervertegenwoordiging is van vrouwen in scholingsprogramma's. Voor het vaststellen van het feitelijke niveau van de vooropleiding bij aanvang van een opleiding aan een van de vijf centra, is in tabel 4.1 de hoogst genoten opleiding van de cursisten weergegeven. Hiermee wordt gerefereerd aan de hoogste opleiding die met een diploma c.q. certificaat is afgesloten. Opleidingen aan de streekschoo//leerlingwezen, Centra voor Vakopleidingen en schriftelijke cursussen thuis zijn hierbij afhankelijk van het niveau als voorbereidend, middelbaar of hoger beroepsonderwijs geclassificeerd. Ongeveer de helft van de cursisten heeft een diploma behaald op VBO-niveau, een kwart heeft cen MAVO-diploma en eveneens een kwart heeft een MBO-, HAVO- of VWO-diploma. Zoals in hoofdstuk 2 is aangegeven met een lager opleidingsniveau de kans op reïntegratie relatief klein. Ongeveer $75 \%$ van de hier beschreven cursistenpopulatie heeft in die zin een verminderde kans op reïntegratie. Op centrumniveau blijkt EEGA relatief veel cursisten te scholen die reeds een middelbare of hogere beroepsopleiding als vooropleiding hebben $\left(\mathrm{chi}^{2}=86.9\right.$, $\mathrm{p}<0.001$ ). Bij het opleidingsniveau van de cursisten moet echter de kanttekening worden geplaatst dat diplomering op een bepaald niveau niet alleszeggend is, aangezien de aanwezige beperkingen van invloed kunnen zijn op het functioneringsniveau. Met name voor de cursisten met traumatisch hersenletsel kan dit een rol spelen (zie hiervoor tabel 4.3).

Een groot deel van de cursisten heeft, voorafgaande aan het scholingsprogramma, gewerkt (65.3\%). De cursisten die voorafgaande aan het scholingsprogramma hebben gewerkt, zijn gemiddeld negen jaar ouder bij aanvang van het programma ( 31.2 jaar versus 22.4 jaar; $\mathrm{F}=84.0, \mathrm{p}<0.001$ ).

In tabel 4.2 wordt een aantal aspecten van het arbeidsverleden van de cursisten weergegeven. Van de cursisten die actief zijn geweest op de arbeidsmarkt wordt in hoofdcategorieën (Standaard Beroepenclassificatie CBS, 1993) de sector en het niveau aangegeven waarop het laatst uitgeoefende beroep kan worden geclassificeerd. 


\begin{tabular}{|c|c|c|c|c|c|c|c|}
\hline \multirow[b]{2}{*}{ lager niet spec. } & \multicolumn{2}{|c|}{$\begin{array}{l}\text { Totaal } \\
n=713\end{array}$} & \multirow{2}{*}{$\begin{array}{c}\begin{array}{l}\text { Hoensbroeck } \\
\mathrm{n}=346\end{array} \\
40\end{array}$} & \multirow{2}{*}{$\begin{array}{l}\begin{array}{l}\text { Werkenrode } \\
\mathrm{n}=52\end{array} \\
12\end{array}$} & \multirow{2}{*}{$\begin{array}{l}\text { Sonneheerdt } \\
n=42 \\
8\end{array}$} & \multirow{2}{*}{$\begin{array}{r}\begin{array}{l}\text { Heliomare } \\
n=168\end{array} \\
36\end{array}$} & \multirow{2}{*}{$\begin{array}{c}\begin{array}{l}\text { EEGA } \\
\mathrm{n}=105\end{array} \\
15\end{array}$} \\
\hline & 111 & $16 \%$ & & & & & \\
\hline lager agrarisch & 11 & $2 \%$ & 8 & 1 & 1 & 1 & \\
\hline lager technisch & 142 & $20 \%$ & 81 & 21 & 3 & 24 & 13 \\
\hline lager transport & 30 & $4 \%$ & 24 & 1 & 2 & 3 & \\
\hline lager paramedisch & 18 & $3 \%$ & 4 & 2 & & 11 & 1 \\
\hline lager adm/com & 76 & $11 \%$ & 24 & 10 & 14 & 22 & 6 \\
\hline lager verzorgend & 26 & $4 \%$ & 6 & 4 & 1 & 12 & 3 \\
\hline middel technisch & 118 & $17 \%$ & 86 & & 1 & 25 & 6 \\
\hline middel paramedisch & 28 & $4 \%$ & 8 & & 3 & 4 & 13 \\
\hline middel adm/com & 41 & $6 \%$ & 16 & & 2 & 9 & 14 \\
\hline middel soc, maatsch. & 10 & $1 \%$ & 2 & & & & 8 \\
\hline middel verzorgend & 13 & $2 \%$ & 4 & & 1 & 4 & 4 \\
\hline hoger pedagogisch & 22 & $3 \%$ & 10 & & 1 & 3 & 8 \\
\hline hoger technisch & 7 & $1 \%$ & 3 & & & 3 & 1 \\
\hline hoger anders & 15 & $2 \%$ & & & & 10 & 5 \\
\hline Niet bekend & 45 & $6 \%$ & & & & & \\
\hline
\end{tabular}

De cursisten van de centra zijn in hun laatste functie voornamelijk werkzaam geweest in beroepen op lager of middelbaar niveau. Het beroepenveld waarin de cursisten werkzaam zijn betreft met name de technische beroepen en beroepen in de administratief-economische richting. Waar de cursisten van Hoensbroeck, Heliomare en EEGA in een aantal gevallen een beroep op middelbaar niveau uitoefenden, blijken de cursisten van Sonneheerdt en Werkenrode werkzaam te zijn geweest in functies op met name lager niveau. De beroepen op een lager niveau zijn een logisch gevolg van de door deze groepen cursisten gevolgde opleidingen op een lager niveau. Bekend is dat de reintegratickans in ongeschoolde beroepen klein is. Deze beroepen kennen namelijk veelal een zware fysieke inspanning, vergeleken met beroepen waarvoor een middelbare of hogere scholing is vereist (Bloemhoff \& De Winter, 1990). De kans op succesvolle reïntegratie zonder het ondernemen van extra activiteiten, lijkt alleen al op basis van deze gegevens erg klein voor een deel van de cursistenpopulatie. 


\section{Aandoeningen}

Een overzicht van de aandoeningen waarmee de cursisten van de respectievelijke centra kampen, staat in tabel 4.3. De indeling is een afgeleide van de categorisering van Hanssen (1985). Samengevoegd zijn de arm- en beenamputatic, toegevoegd is psychische problematiek. Onder het begrip hersenletsel vallen traumatisch hersenletsel ontstaan op latere leeftijd, maar tevens door een geboortetrauma ontstane degeneratieve hersenziektes (infantiele encephalopathie) met als belangrijkste restverschijnselen halfzijdige of volledige verlammingen. Tot de categorie aandoeningen van het bewegingsapparaat behoren zowel aandoeningen van de wervelkolom die gevolgen hebben voor het perifere zenuwstelsel, bijvoorbeeld hernia nuclea pulposi, alsmede orthopedische problematiek waaronder degeneratieve afwijkingen van de wervelkolom of andere skeletdelen en kraakbeenziektes. Bij reuma moet worden gedacht aan de ziekte van Bechterew, reumatoïde arthritis en fibromyalgie. Vervolgens omvatten neurologische aandoeningen onder meer progressieve spierziektes als de ziekte van Duchenne, maar ook multiple sclerose, poliomyelitis en spina bifida. Tenslotte zijn aandoeningen van de ademhalingswegen, huidziekten, stofwisselingsziekten, hydrocephalus, epilepsie of brandwonden onder de categorie diversen ondergebracht. Aangezien een aantal cursisten meer dan één aandoening (probleem) heeft, overstijgt het totaal aantal aandoeningen het aantal cursisten en het percentage van $100 \%$.

\begin{tabular}{|c|c|c|c|c|c|c|c|}
\hline & $\begin{array}{l}\text { Totaa } \\
1092 \\
\end{array}$ & & $\begin{array}{l}\text { Hoensbroeck } \\
\mathrm{n}=386\end{array}$ & $\begin{array}{l}\text { Werkenrode } \\
n=113\end{array}$ & $\begin{array}{l}\text { Sonncheerdt } \\
n=171\end{array}$ & $\begin{array}{l}\text { Heliomare } \\
n=260\end{array}$ & $\begin{array}{l}\operatorname{EEGA} \\
n=162\end{array}$ \\
\hline Arm/been-amputatic & 39 & $4 \%$ & 24 & 5 & & 8 & 2 \\
\hline Dwarslaesie & 35 & $3 \%$ & 12 & 6 & I & 10 & 6 \\
\hline Hersenletsel/CVA & 160 & $15 \%$ & 52 & 44 & 7 & 30 & 27 \\
\hline Handpathologie & 31 & $3 \%$ & 19 & 3 & & 9 & \\
\hline Psychische problematiek & 123 & $11 \%$ & 49 & 5 & I & 21 & 47 \\
\hline Bewegingsapparaat & 427 & $39 \%$ & 245 & 26 & 5 & 104 & 47 \\
\hline Visusbeperking & 194 & $18 \%$ & 12 & 7 & 171 & 4 & \\
\hline Siechthorend/doof & 27 & $2 \%$ & 15 & 3 & 4 & 5 & \\
\hline Reuma & 81 & $7 \%$ & 49 & 4 & & 21 & 7 \\
\hline Neurologische aandoening & 1,3 & $10 \%$ & 39 & 29 & & 21 & 14 \\
\hline Polytraumatise & 12 & $1 \%$ & & 6 & & 4 & 2 \\
\hline Diversen & 147 & $13 \%$ & 21 & 70 & 3 & 17 & 36 \\
\hline
\end{tabular}


Over het geheel gezien blijken aandoeningen van het bewegingsapparaat relatief het meest voor te komen. Daarnaast komen hersenletsels, blind- of slechtziendheid, psychische aandoeningen of neurologische aandoeningen relatief het meest voor in de cursistenpopulatie (tabel 4.3).

Wanneer op centrumniveau wordt gekeken, blijken de cursisten van Hoensbroeck met name aandoeningen van het bewegingsapparaat te hebben. Ook, maar in mindere mate, is sprake van reumatische aandoeningen, hersenletsel/CVA, psychische problematiek en neurologische aandoeningen. De cursistenpopulatie van Werkenrode wordt gekenmerkt door aandoeningen van het bewegingsapparaat, hersenletsel en neurologische aandoeningen. Psychische problematiek komt minder voor. Een groot deel van de cursisten van Werkenrode heeft ziektes of aandoeningen die niet onder een van de categorieën is thuis te brengen. De gehele populatie cursisten van Sonneheerdt heeft visuele aandoeningen. Cursisten van Heliomare blijken voornamelijk aandoeningen te hebben van het bewegingsapparaat en hersenletsel/CVA. Psychische problematiek blijkt eveneens bij een aantal cursisten een rol te spelen. Aandoeningen van het bewegingsapparaat en psychische problematiek komen het meest voor bij de cursisten van EEGA.

Complexe (medische) problematiek, hiermee wordt gerefereerd aan het hebben van meer dan één aandoening, speelt bij meer dan de helft (59\%) van de cursisten van Hoensbroeck. Bij tenminste $40 \%$ van de cursisten van Werkenrode is complexe problematiek aan de orde. Dit geldt eveneens voor $21 \%$ van de cursisten van EEGA en voor $9 \%$ van de cursisten van Heliomare. 12\% Van de cursisten van Sonneheerdt heeft $12 \%$ een additionele aandoening.

Behoudens enkele uitzonderingen worden geen patronen ontdekt met betrekking tot het voorkomen van meerdere aandoeningen bij een persoon. Personen met verlammingsverschijnselen worden vaker dan anderen geconfronteerd met epileptische aanvallen. Daarnaast blijken personen met psychische problematiek vaker klachten aan het bewegingsapparaat te vertonen.

Vastgesteld kan worden dat het aandoeningenpatroon van de cursisten duidt op ernstige tot zeer ernstige aandoeningen, die - zoals blijkt uit de genoemde factoren uit hoofdstuk 2 - niet bevorderlijk zijn voor een succesvolle reîntegratic.

\section{Beperkingen}

De lichamelijke beperkingen die de cursisten van de vijf centra ondervinden zijn weergegeven in tabel 4.4. De lichamelijke beperkingen liggen logischerwijs in het verlengde van de hierboven beschreven aandoeningen 
Tabel 4.4 Beperkingen cursisten. Aantallen en percentages

\begin{tabular}{lccccccc}
\hline & \multicolumn{2}{l}{$\begin{array}{l}\text { Total } \\
1092\end{array}$} & $\begin{array}{l}\text { Hoensbroeck } \\
\mathrm{n}=386\end{array}$ & $\begin{array}{l}\text { Werkenrode } \\
\mathrm{n}=113\end{array}$ & $\begin{array}{l}\text { Sonneheerdt } \\
\mathrm{n}=171\end{array}$ & $\begin{array}{l}\text { Heliomare } \\
\mathrm{n}=260^{*}\end{array}$ & $\begin{array}{c}\text { EEGA } \\
\mathrm{n}=162\end{array}$ \\
\hline zittenlopen & 671 & $61 \%$ & 293 & 73 & 13 & 84 & 208 \\
Armhandgebruik & 183 & $17 \%$ & 87 & 23 & 6 & 39 & 28 \\
Zien & 205 & $19 \%$ & 9 & 13 & 171 & 4 & 8 \\
Horen & 48 & $4 \%$ & 13 & 4 & 9 & 6 & 16 \\
Spreken & 19 & $2 \%$ & 5 & 7 & & 2 & 5 \\
Overig & 183 & $17 \%$ & 13 & 24 & & 6 & 140 \\
\hline
\end{tabular}

- missing values: 119

Uit tabel 4.4 kan worden afgeleid dat het merendeel van de cursisten beperkingen ervaart in het zitten en/of het lopen. Daarnaast is een groot deel van de cursisten beperkt in het zien (dit betreft voornamelijk cursisten van Sonneheerdt) en een groot aantal beperkt in hun arm/handgebruik. Relatief een klein aantal cursisten is beperkt in het horen of spreken. Voor wat betreft de populatie van Heliomare vormt het grote aantal missing values aanleiding de geconstateerde beperkingen niet als kenmerkend voor het centrum te benoemen. De cursisten van Werkenrode, Hoensbroeck en EEGA ondervinden met name beperkingen in het lopen, zitten/staan en arm/handgebruik.

De beperkingen die worden ervaren hebben voornamelijk betrekking op fysicke of visuele beperkingen. Ten aanzien van de kans op reïntegratie betekenen zowel fysieke als visuele beperkingen dat aanpassingen moeten worden gerealiseerd, teneinde deze beperkingen te minimaliseren. Het moeten regelen van aanpassingen kan een belemmerende factor vormen wanneer het gaat over reïntegratiesucces (hoofdstuk 2).

Samenvattend kan ten aanzien van de karakteristieken van de cursisten die een scholingsprogramma volgen bij een van de vijf centra worden geconcludeerd dat zij allen volledig arbeidsongeschikt zijn verklaard, de populatie voor driekwart uit mannen bestaat, een gemiddelde leeftijd hebben van 28 jaar, een gemiddeld laag opleidingsniveau hebben, langdurig uit het arbeidsproces zijn dan wel nog niet eerder hebben gewerkt, alvorens te starten met het scholingsprogramma sinds lange tijd geen onderwijs hebben gevolgd, aandoeningen hebben van het bewegingsapparaat, hersenletsel hebben (al dan niet aangeboren), blind of slechtziend zijn of psychische aandoeningen hebben $\mathrm{en}$ beperkingen ervaren in het lopen/staan, arm- en/of handgebruik of visusbeperkingen ervaren. 
De geconstateerde verschillen in karakteristieken ten aanzien van de cursistenpopulaties van de hier beschreven reïntegratiecentra maken het mogelijk om te toetsen of scholingsprogramma's voor verschillende doelgroepen leiden tot de gewenste effecten of dat het een specifieke interactie betreft tussen cursistkenmerken en opleiding.

\subsection{BESCHRIJVING PROGRAMMA}

Zoals blijkt uit het onderzoeksmodel zijn de scholingsprogramma's opgebouwd uit diverse onderdelen, namelijk een assessment, het vaktheoretische gedeelte, het ondersteunings- en begeleidingsgedeelte en de bemiddeling. De diepte-interviews met afdelingshoofden, de focusgroepinterviews met docenten en de schriftelijke vragenlijsten voor de hoofden van de opleidingen leveren de informatie die nodig is om de verschillende onderdelen in kaart te brengen. In deze paragraaf zullen de assessment, het vaktheoretische gedeelte, het ondersteunings- en begeleidingsgedeelte en de bemiddeling respectievelijk kort worden beschreven.

Deze beschrijvingen zullen vervolgens in paragraaf 4.4 worden afgezet tegen de in de literatuur beschreven succesfactoren voor scholingsprogramma's ten behoeve van reìntegratie (zie hoofdstuk 2).

\subsubsection{Assessment}

Tijdens de assessment wordt met behulp van diverse methodieken nagegaan voor welk scholingsprogramma de kandidaat qua capaciteiten, interesses en mogelijkheden in aanmerking komt. Daarnaast wordt de noodzakelijke begeleiding op sociaal-psychologisch-, leertechnisch- en materieel gebied voor de betreffende kandidaat in kaart gebracht.

In het navolgende wordt beschreven uit welke onderdelen de assessment procedure is opgebouwd. Aansluitend wordt ingegaan op de mogelijke uitkomsten van de assessment. Tot slot wordt ingegaan op het individuele reintegratieplan waarin de aandachtspunten van de individuele cursist gedurende het opleidingstraject worden geformuleerd.

\section{Intakegesprek}

Het intakegesprek heeft als doel een zo goed mogelijk beeld te verkrijgen van de kandidaat en wordt tevens gebruikt om eventueel naar voren komende aandachtspunten direct te verwerken in de inhoud en de opbouw van de assessment procedure. Tijdens 
dit gesprek wordt op gestructureerde wijze een aantal basisgegevens van de kandidaat geînventariseerd. Het betreft onder meer personalia, contactadres, scholingsverleden, arbeidsverleden, datum uitval en medische situatie. Het intakegesprek vindt plaats dan wel direct voorafgaande aan de assessment, dan wel enige weken van te voren. Het gesprek heeft een oriënterend karakter voor zowel de kandidaat als de intaker.

\section{Psychologisch onderzoek en psychotechnisch onderzoek}

Bij het psychologisch en psychotechnisch onderzoek kan een onderscheid worden gemaakt tussen enerzijds testen die gericht zijn op het vaststellen van cognitieve en differentiele capaciteiten, en anderzijds testen die zich richten op de persoonlijkheid. De resultaten van de testen worden aangevuld met gegevens uit gesprekken tussen de psycholoog en een kandidaat. Het doel van het psychologisch en psychotechnisch onderzoek is inzicht verkrijgen in iemands persoonlijkheid alsmede sociale vaardig. heden, intellectuele capaciteiten, interesses en mentale belastbaarheid. Het psychologisch onderzoek en het psychotechnisch onderzoek vormen de belangrijkste onderdelen in relatie tot de leerbaarheid en de cognitieve haalbaarheid van de voorgestane opleiding alsmede de vraag of er op persoons- c.q. gedragsniveau van een zodanige interferentie sprake is dat het niet gewenst is om in die opleidingsrichting een studie te gaan volgen.

\section{Functioneel medisch onderzoek}

Medisch onderzoek van een kandidaat heeft als doel vast te stellen of op grond van medische aspecten en lichamelijke beperkingen (geen) bezwaar bestaat tot het volgen van de voorgestane opleiding en de daaraan gekoppeide toekomstige werksituatie. In de verwijzingsstructuur betreft dit een verantwoordelijkheid van de verzekeringsgeneeskundige. Hoensbroeck en Werkenrode hanteren de opvatting dat zij hierin ook een verantwoordelijkheid dragen aangezien het medisch onderzoek bij de centra altijd plaatsvindt in relatie tot mogelijkheden om een specifieke functie uit te oefenen.

Sonneheerdt gaat ervan uit dat kandidaten in principe normaal fysiek belastbaar zijn. Derhalve is functioneel medisch onderzoek niet nodig. Wel wordt de visus van de kandidaten getest tijdens een low vision onderzoek. Dit onderzoek heeft als doel zicht te krijgen op de visuele beperkingen van de kandidaat en de hiervoor benodigde aanpassingen.

Het belastbaarheidsrapport van de arbeidsdeskundige geeft Heliomare voldoende zekerheid om de vraag te kunnen beantwoorden of een kandidaat een scholingsprogramma kan volgen. Indien hierover twijfel bestaat wordt de belastbaarheid alsnog bepaald door de bedrijfsarts. 
EEGA verricht evenals Heliomare niet standaard een medisch onderzoek. Indien een medisch onderzoek is geïndiceerd, wordt dit verzorgd door een medisch adviseur.

\section{Fysiek-functioneel belastbaarheidsonderzoek}

Met het fysiek functioneel belastbaarheidsonderzoek kan worden bepaald in welke mate een kandidaat lichamelijk belastbaar is. Voor het fysiek functioneel belastbaarheidsonderzoek wordt door Hoensbroeck, Werkenrode en EEGA gebruik gemaakt van de Ergos Werk Simulator, een gevalideerd instrument waarmee het fysiek verwerkingsvermogen in relatie tot de arbeidsbelasting kan worden gemeten (Reneman, Jaegers, Muskee, Schroër \& Göeken, 1997). Door arbeidssimulaties, in de vorm van een nauwkeurige nabootsing van werkplekspecifieke fysieke belastingen wordt via een geautomatiseerde dataverwerking, de lichamelijke belastbaarheid bepaald. Hierbij wordt niet alleen gekeken naar de tijd die iemand in een bepaalde houding kan werken, maar ook of het daarbij behorende werktempo kan worden volgehouden. Het aan de werksimulator gekoppelde databestand omvat ruim 13.000 beroepen, waarvan middels circa veertig parameters is aangegeven wat de belastingseisen zijn. Hieruit komt een advies van eventuele arbeidsmogelijkheden. De Ergos meet zowel kracht, uithoudingsvermogen als duurbelasting (Mul, 1999).

Bij de centra Heliomare en Sonneheerdt wordt de fysieke belastbaarheid niet gemeten (zie 'functioneel medisch onderzoek').

\section{Motorisch onderzoek}

Bij het motorisch onderzoek kan worden onderscheiden, een onderzoek naar de grove motoriek en een onderzoek naar de fijne motoriek. Voor beide onderzoeken wordt gebruik gemaakt van oefenwerksituaties, i.c. worksamples (zie onder meer Couch Cole \& Wilkins, 1989).

\section{Beroepsgerichte oriëntatie}

De affiniteit en vaardigheden ten aanzien van een bepaalde beroepsrichting wordt door de centra op diverse wijzen bepaald. Alle centra maken gebruik van beroepskeuze testen alsmede beroepen affiniteiten testen. Deze testen hebben zowel een oriënterende- als een selecterende en bevestigende functie. Daarnaast worden bij EEGA groepsgesprekken gevoerd en maken Werkenrode en Hoensbroeck gebruik van meer geavanceerde worksamples, de zogenoemde job samples. Hierdoor krijgen kandidaten de kans om hun affiniteit te bepalen ten aanzien van een bepaalde beroepsrichting. De kandidaten van Sonneheerdt krijgen de gelegenheid enige tijd mee te draaien bij een voorkeursvakrichting. 


\section{Toevoegingen aan de assessment}

In geval van twijfel ten aanzien van het te ontwikkelen individueel reĭntegratie plan kan, naast de beschreven vaste onderdelen, additioneel onderzoek worden verricht en kunnen activiteiten worden toegevoegd worden, zoals neuropsychologisch onderzock, dyslexie onderzoek, onderzoek naar leermoeilijkheden, ergotherapeutisch onderzoek en didactisch onderzoek. Bovendien kan een meerdaagse oriëntatie bij de gewenste vakrichting plaatsvinden.

\section{Beslissingsprocedure}

Aan het einde van de assessment wordt tijdens een multidisciplinaire teambijeenkomst een beslissing genomen omtrent het vervolgtraject voor de kandidaat. Hoensbroeck hanteert als enig centrum uitsluitingscriteria; op basis van de gegevens van de assessment wordt bepaald of een kandidaat in staat is te voldoen aan de opleidingseisen. Analyse van de assessmentgegevens van Hoensbroeck wijst uit dat met name intelligentie als selectiecriterium wordt gehanteerd.

\section{Individueel reïntegratie plan}

Uitgaande van de bevindingen tijdens de assessment wordt het individuele reĭntegratieplan opgesteld, waarin wordt vermeld het scholingsplan. de noodzakelijke individuele ondersteuning en begeleiding en het verwachte eindniveau. Individuele ondersteuning en begeleiding kan betrekking hebben op studievaardigheden alsmede begeleiding op medisch-, ergotherapeutisch- en/of psycho-sociaal gebied.

\section{Instroomprocedure}

Het individuele reïntegratieplan wordt verstuurd naar de verwijzer teneinde toestemming te verkrijgen voor de uitvoering ervan. Wanneer toestemming wordt verleend, kan met het scholingsprogramma worden gestart.

De minimale tijd tussen moment van uitval en instroom in het scholingsprogramma bedraagt twee jaar.

\subsubsection{Vaktheoretisch gedeelte van het scholingsprogramma}

De docenten van de reïntegratiecentra onderwijzen een populatie cursisten die zowel qua theoretische als praktische vaardigheden vrij heterogeen is samengesteld. Dit vereist volgens de hoofden opleiding een gedifferentieerde aanpak afgestemd op het niveau van de individuele cursist. Volgens de hoofden opleiding heeft derhalve het vaktheoretisch gedeelte bij alle reëntegratiecentra een individueel karakter, hetgeen tot uitdrukking komt in de voornamelijk modulaire werkwijze bij zowel het 
theoriegedeelte als het praktijkgedeelte. De keuze voor een modulaire werkwijze is volgens de hoofden opleiding voornamelijk ingegeven door het bevorderende effect op de mogelijkheid voor de cursist om op eigen tempo en niveau te werken. De gedifferenticerde aanpak is ook terug te vinden in het feit dat de docenten gebruik maken van diverse instructiemethoden en werkvormen, variërend van mondelinge instructie en het aanbieden van schriftelijk instructiemateriaal tot het gebruik van demonstratiemodellen, apparatuur en audiovisuele hulpmiddelen. De cursisten zijn tijdens de theorielessen voornamelijk bezig met het beantwoorden van vragen, het maken van verslagen en werkstukken, het voeren van discussies, het houden van rollenspellen en voordrachten.

In schema 4.1 staat een overzicht van de vakrichtingen waarin de cursisten een certificaat/diploma kunnen behalen (gedurende de onderzochte periode).

\begin{tabular}{lllll}
\hline \multicolumn{4}{l}{ Sehema 4.1 } & Vakrichtingen waarin een scholing kan worden afgerond \\
\hline Sonneheerdt & Werkenrode & Hoensbroeck & Heliomare & EEGA \\
\hline Administratic & Administratic & Administratic & Administratic & Administratic \\
Informatica & Tuinbouw & Informatica & Informatica & Elektronica \\
Grafische & Grafische & Fijnmechanica & Technisch Tekenen & Automatisering \\
technicken & technieken & Werktuigbouwkundig & Fijnmechanische & Commercie \\
Elektrotechnick & Metaal & tekenen & metaalopleiding & Logistiek \\
Fietstechnick & & & Elektrotechnick & Receptionist \\
Meubelstofferen & & Grafische techniek. & telefonist \\
Telemarketing. & & & \\
\hline
\end{tabular}

De docenten merken op dat met name aan de praktijkcomponent van de diverse vakrichtingen veel aandacht wordt besteed, omdat zij van mening zijn dat hierdoor de aansluiting met de toekomstige bedrijfspraktijk optimaal kan verlopen. Hiertoe wordt enerzijds gebruik gemaakt van simulatiebedrijven. anderzijds worden regelmatig opdrachten uit het bedrijfsleven aangenomen en verwerkt. Mogelijke problemen die in de praktijk ontstaan worden rechtstreeks teruggekoppeld naar de theorielessen. Binnen de praktijkcomponent staat het aanleren c.q. verbeteren van praktische vaardigheden centraal, waarbij tevens aandacht besteed wordt aan communicatieve- en sociale vaardigheden. Bij een aantal reïntegratiecentra maakt een praktijkstage onderdeel uit van het scholingsprogramma.

\subsubsection{Begeleidings- en ondersteuningscomponent}

Binnen de curricula van de reïntegratiecentra is een begeleidings- en ondersteuningscomponent opgenomen, die enerzijds dient ter ondersteuning van het vaktheoretische 
deel en anderzijds bijdraagt aan de voorbereiding van de cursist op de toekomstige bedrijfspraktijk. Onderdelen vormen de psycho-sociale begeleiding, studiebegeleiding. (para)medische begeleiding, voortgangsbegeleiding en (alleen Werkenrode) begeleiding in de woonsituatic.

De psycho-sociale begeleiding wordt voornamelijk geboden door orthopedagogen, psychologen en gedeeltelijk door het onderwijskundig personeel. Onderdelen van deze vorm van begeleiding zijn onder meer trainingen gericht op communicatieve- en sociale vaardigheden, assertiviteit, spanningshantering en handicapverwerking. Deze begeleiding wordt, afhankelijk van de inhoud dan wel individueel aangeboden, dan wel in groepsvorm in en/of buiten de lessen.

Individuele studiebegeleiding wordt verzorgd door begeleidingsmedewerkers en/of docenten en vindt plaats tijdens de lessen, 's middags na de lessen en/of in de avonduren. De studiebegeleiding kan enerzijds vakgericht zijn, anderzijds algemeen in de zin van het trainen van studievaardigheden en studiemethodiek.

(Para)Medische begeleiding wordt aangeboden bij vier van de vijf centra (Sonneheerdt biedt vanwege de specifieke problematiek van de cursistenpopulatie geen paramedische begeleiding). Onderdelen van deze begeleiding zijn onder meer fysiotherapie, ergotherapie en (revalidatie)geneeskundige ondersteuning. De begeleiding vindt voornamelijk plaats tijdens de lessen, waarvoor de cursisten lesvrijstelling krijgen. Naast individuele begeleiding wordt ook groepsgewijze (para)medische begeleiding geboden, bijvoorbeeld aan cursisten die lijden aan de ziekte van Bechterew.

Op alle scholingscentra wordt regelmatig de voortgang van de cursist geèvalueerd waarbij, indien daartoe aanleiding bestaat, het studieprogramma en/of de begeleidingsactiviteiten aangepast kunnen worden. Het individuele reïntegratie plan kan derhalve worden gezien als een vloeiend verlopend proces dat, afhankelijk van de situatie, voortdurend kan worden bijgesteld.

Werkenrode Arbeidsintegratie biedt als enige begeleiding in de woonsituatie, met als doel het bevorderen c.q. verbeteren van het zelfstandig functioneren van de cursisten in de maatschappij. Werkenrode heeft hiervoor de beschikking over woonaccommodaties zowel op - als buiten het terrein waarbij de intensiteit van de begeleiding varieert per accommodatie.

\subsubsection{Bemiddeling naar arbeid}

Ten aanzien van de bemiddeling kan een onderscheid worden gemaakt tussen plaatsing en nazorg. Plaatsingsactiviteiten richten zich voornamelijk op die activiteiten die worden uitgevoerd in het kader van het vinden van een arbeidsmarktpositie voor de 
cursist. Nazorg heeft voornamelijk betrekking op de ondersteuning van de oud-cursist in algemene zin.

In eerste instantie zien de reïntegratiecentra arbeidstoeleiding niet als een hoofdtaak die door hen zou moeten worden verzorgd, aldus de hoofden opleiding. Zij geven aan dat cursisten door het volgen van een op maat gesneden reïntegratietraject dermate zelfstandig worden, dat ze in staat zijn om zelf een baan te vinden en niet afhankelijk hoeven te zijn van de plaatsingsactiviteiten van het reïntegratiecentrum. De begeleiding die de reïntegratiecentra bieden, bestaat onder meer uit het verzorgen van sollicitatie trainingen, het stimuleren van cursisten om zelf activiteiten te ondernemen, het aanbieden van advertenties aan cursisten en/of het contact opnemen met werkgevers, al dan niet naar aanleiding van een vacature. $\mathrm{Na}$ afronding van het scholingsprogramma worden cursisten van Sonneheerdt en EEGA nog gedurende enige maanden meer of minder intensief begeleid bij het zoeken naar een baan in de richting waarin het certificaat/diploma is behaald. $\mathrm{Bij}$ de overige drie centra vindt na afronding van het programma vrijwel geen begeleiding meer plaats.

Nazorg in algemene zin worde geboden tot maximaal één jaar na afronding van het scholingsprogramma. Deze nazorg bestaat voornamelijk uit ondersteuning en advisering op individuele hulpvragen van oud-cursisten.

\subsection{EVALUATIE SCHOLINGSPROGRAMMA'S: TOETSING AAN DE LITERATUUR}

In hoofdstuk 2 is een aantal voonwaarden genoemd waaraan een scholingsprogramma zou moeten voldoen om de kans op het vinden en behouden van werk voor mensen met een afstand tot de arbeidsmarkt vanwege een chronische ziekte of aandoening te vergroten. In deze laatste paragraaf zullen deze voorwaarden met betrekking tot vorm en inhoud van scholingsprogramma's, worden gerelateerd aan de daadwerkelijk gerealiseerde programma's. Ernste et al. (1995) concluderen in hun overzichtsstudie dat met name scholing succesvol is in te zetten als arbeidsreïntegratiemiddel wanneer het beroepsgerichte scholing betreft. De scholingsprogramma's van de reîntegratiecentra betreffen in alle gevallen beroepsgerichte scholing. Schwab \& DiNitto (1993) vinden in hun onderzoek naar gereīntegreerde werknemers met beperkingen, dat de succesvol gereïntegreerde werknemers een reïntegratieprogramma hebben doorlopen waarin relatief veel aandacht wordt besteed aan het in kaart brengen van de mogelijkheden van de persoon en een hierop gerichte scholing en training. Uit de interviews met de professionals uit de reìntegratiecentra kan worden opgemaakt dat 
sprake is van een uitgebreide assessment en een op basis van de uitkomsten van de assessment individueel opgesteld scholingsprogramma. Hiermee wordt eveneens voldaan aan de door Van Elderen et al. (1995) beschreven voorwaarde voor succesvolle reïntegratie, namelijk dat deze wordt vergroot wanneer personen een scholingsprogramma volgen dat leidt tot een functie waarin de aanwezige beperkingen geen belemmeringen meer vormen voor het uitoefenen van deze functie.

De kans op succesvolle reìntegratie wordt volgens Wilgosh \& Müller (1993) vergroot wanneer in reĩntegratieprogramma's aandacht wordt besteed aan het trainen van zowel persoonlijke vaardigheden, sociale vaardigheden als werkgerelateerde vaardigheden. Deze aspecten zijn te herkennen in de werkwijze van de reïntegratiecentra. Berg et al. (1997) voegen hieraan toe dat hierbij specifieke aandacht dient te worden gegeven aan een flexibele werkhouding, vanwege de voortdurend veranderende werkomgeving. In hoeverre de reïntegratie centra hiervoor aandacht kan niet worden opgemaakt uit de gehouden interviews.

Wanneer beroepsgerichte scholing wordt aangevuld met arbeidstraining en fysieke training blijkt dit een positief effect te hebben op de reïntegratie kansen voor personen met beperkingen (Hennessey \& Muller, 1995). Binnen de praktijkcomponent van de scholingsprogramma's werken cursisten in simulatiebedrijven, voeren concrete opdrachten uit afkomstig uit het reguliere bedrijfsleven en wordt veelal een praktijkstage doorlopen. Deze elementen van het curriculum kunnen worden gezien als arbeidstraining. De mogelijkheid om stage te lopen heeft tevens een positieve invloed op langdurige succesvolle reïntegratie, c.q. het behouden van werk op de lange termijn (Dauwalder \& Hoffmann, 1992; Classen et al., 1993). Aan het tweede aspect dat wordt genoemd door Hennessey \& Muller (1995), fysieke training wordt, zoals blijkt uit de interviews weliswaar aandacht besteed, maar vormt gewoonlijk geen standaardonderdeel van het curriculum en is derhalve ook niet genoemd in de beschrijving.

Een aantal auteurs meldt het belang van het werken met kleine groepen waarin iedereen een geïndividualiseerd programma kan volgen (Lubbe, 1990; Mul et al., 1995; Bolton \& Akridge, 1995), hetgeen van wezenlijke invloed blijkt te zijn op succesvolle reïntegratie. In alle onderzochte reïntegratiecentra wordt een individuele werkwijze gehanteerd en in die zin voldoen zij aan de hiervoor beschreven voorwaarden. Zeer intensieve reïntegratieprogramma's blijken effectief wanneer het gaat om langdurig succesvolle reïntegratie van personen met een traumatisch hersenletsel en personen met aandoeningen van het bewegingsapparaat (Ahlgren \& Hammarstrom. 1999; Groswasser et al., 1999). Het is echter niet duidelijk wat de auteurs verstaan onder 'zeer intensief, waardoor het niet mogelijk is de uitspraken te toetsen aan de 
werkwijze van de in dit proefschrift beschreven reïntegratieprogramma's. Uit de interviews met de diverse geledingen binnen de reïntegratiecentra (inclusief interviews met cursisten) kan wel worden opgemaakt dat de programma's als intensief worden beoordeeld.

Aandacht voor de bemiddeling van personen met een arbeidsongeschiktheidsuitkering vanwege de aanwezige beperkingen blijkt van wezenlijk belang. Niet alleen de mogelijkheid tot bemiddeling, maar ook het verstrekken van goede voorlichting aan de toekomstige werkgevers alsmede het benadrukken van de kwaliteit van de sollicitanten zijn factoren die een positieve invloed blijken te hebben op succesvolle reïntegratie (Van den Berg \& Van der Veer, 1990a en b).

Het belang vervolgens van een netwerk onder werkgevers voor een succesvolle reïntegratie blijkt uit diverse studies (Lamberts, 1982; Bijlsma, 1987; Berkell, 1987; Reihl, 1988: Dauwalder \& Hoffmann, 1992). De in dit proefschrift beschreven reïntegratiecentra hebben weliswaar een bemiddelingscomponent, echter directe bemiddelingsactiviteiten (inclusief voorlichting) zoals in het bovenstaande genoemd, zijn in geringere mate aanwezig. De reĭntegratiecentra beschikken vrijwel allemaal over een netwerk van werkgevers, deels vanwege hun stageprogramma en deels vanwege de relatie die de praktijkdocenten onderhouden met de arbeidsmarkt.

Samenvattend kan worden gesteld dat de scholingsprogramma's in hoge mate voldoen aan de in hoofdstuk 2 beschreven voorwaarden voor succesvolle reïntegratie. De reïntegratiecentra hanteren een uitgebreide assessment, waarin zowel aandacht voor de psychische en fysieke belastbaarheid, alsmede psychodiagnostiek, motorische vaardigheden en beroepsgerichte orie̋ntatie. Binnen de vaktheoretische component staat een individuele benadering centraal, hetgeen tot uiting komt in de modulaire werkvormen en wordt relatief veel aandacht besteed aan de praktijkcomponent waarbij niet alleen vaktechnische vaardigheden maar ook beroepsgerichte, sociale en communicatieve vaardigheden onderdeel uitmaken van het programma. Het ondersteunings- en begeleidingsgedeelte omvat een diversiteit aan voornamelijk individuele begeleidingsvormen gericht op de persoonlijke ontwikkeling van de cursist en waar nodig additioneel aan de vaktheoretische inhoud van het scholingsprogramma. Tot slot is voornamelijk sprake van indirecte bemiddelingsactiviteiten, teneinde de cursist te ondersteunen in het zelfstandig vinden van een baan in de gekozen vakrichting. Nazorg vindt vrijwel alleen vraaggericht plaats. 


\subsection{WAARDERING SCHOLINGSPROGRAMMA}

De beschrijving van het curriculum is gebaseerd op diepte-interviews en focusgroep interviews met professionals en leidinggevenden. Het betreft een eenzijdige visie op de inhoud en vormgeving van de scholingsprogramma's en de vraag is in hoeverre deze overeenkomt met de visie van diegenen die de scholingsprogramma's doorlopen, de personen die volledig arbeidsongeschikt zijn verklaard. Om dat te toetsen is ook aan de oud-cursisten gevraagd het scholingsprogramma te beoordelen. Daarnaast is gevraagd in hoeverre de oud-cursisten tevreden zijn over de inhoud en vormgeving van het scholingsprogramma. Dit laatste kan tevens een indicatie zijn voor het mogelijk succes van dergelijke programma's.

Aan de oud-cursisten die een reïntegratietraject hebben doorlopen bij de scholingscentra is hun mening gevraagd over de verschillende onderdelen van het scholingsprogramma, namelijk over de inhoud en organisatie van het vaktheoretisch deel van het scholingsprogramma, over de begeleidings- en ondersteuningscomponent en over de plaatsing en nazorg. De mening van de oud-cursisten over de assessmentperiode is niet aan hen gevraagd. Deze periode neemt maximaal een week in beslag van het totale scholingsprogramma. In een retrospectief onderzoek als het hier gepresenteerde is de kans op herinneringsbias dermate groot dat het realiteitsgehalte van de antwoorden sterk aan twijfel onderhevig zal zijn. Eveneens komt in deze paragraaf aan de orde in hoeverre het scholingsprogramma van invloed is geweest op de persoonlijke ontwikkeling van de cursist. In het hiernavolgende worden de resultaten van de telefonische survey gepresenteerd die betrekking hebben op de meningen van de cursistenpopulatie ten aanzien van de inhoud en vormgeving van het vaktheoretisch gedeelte, het ondersteunings- en begeleidingsgedeelte en de bemiddeling, alsmede de bijdrage van deze onderdelen aan de voorbereiding op de arbeidsmarkt en de bijdrage aan de persoonlijke ontwikkeling van de cursist.

\section{Waardering vaktheoretisch gedeelte}

De oud-cursisten zijn in het algemeen zeer tevreden over de inhoud en vormgeving van de vaktheoretische component (tabel 4.5). Het merendeel van de oud-cursisten is van mening dat voldoende aandacht aan theorie en praktijk wordt geschonken (respectievelijk $84 \%$ en $70 \%$ ) en dat voldoende praktijkapparatuur voorhanden is $(85 \%)$. Het gebruikte lesmateriaal is van goede kwaliteit $(80 \%)$. Het schriftelijk lesmateriaal wordt door de oud-cursisten geschikt bevonden om zelfstandig mee te werken $(78 \%)$. In het algemeen wordt het niveau en het tempo van de vaktheoretische component als goed ervaren (respectievelijk $83 \%$ en $74 \%$ ). 
Tabel 4.5 Mening oud-cursisten over verschillende onderdelen van het scholingsprogramma $(\mathrm{n}=504)$. Aantallen en percentages.

\begin{tabular}{|c|c|c|c|c|c|c|c|c|c|c|c|c|c|c|}
\hline & \multicolumn{4}{|c|}{$\begin{array}{l}\text { Totaal } \\
(n=504)\end{array}$} & \multicolumn{2}{|c|}{$\begin{array}{l}\text { Hoensbroeck } \\
(n=199)\end{array}$} & \multicolumn{2}{|c|}{$\begin{array}{l}\text { Werkenrode } \\
(\mathrm{n}=58)\end{array}$} & \multicolumn{2}{|c|}{$\begin{array}{l}\text { Sonneheerdt } \\
(\mathrm{n}=77)\end{array}$} & \multicolumn{2}{|c|}{$\begin{array}{l}\text { Heliomare } \\
(\mathrm{n}=97)\end{array}$} & \multicolumn{2}{|c|}{$\begin{array}{l}\text { EEGA } \\
(\mathrm{n}=73)\end{array}$} \\
\hline & eens & & onec & ens & eens & & eens & & eens & & eens & & eens & \\
\hline $\begin{array}{l}\text { Voldoende aandacht voo } \\
\text { theorie } * .\end{array}$ & 425 & $84 \%$ & 37 & $7 \%$ & 186 & $93 \%$ & 46 & $79 \%$ & 57 & $74 \%$ & 81 & $84 \%$ & 55 & $75 \%$ \\
\hline $\begin{array}{l}\text { Voldoende aandacht voo } \\
\text { praktijk } \ldots\end{array}$ & 352 & $70 \%$ & 95 & $19 \%$ & 153 & $77 \%$ & 51 & $88 \%$ & 53 & $69 \%$ & 48 & $50 \%$ & 47 & $65 \%$ \\
\hline $\begin{array}{l}\text { Voldoende } \\
\text { praktijkapparatuur }\end{array}$ & 428 & $85 \%$ & 46 & $9 \%$ & 168 & $84 \%$ & 54 & $93 \%$ & 64 & $83 \%$ & 77 & $81 \%$ & 65 & $89 \%$ \\
\hline $\begin{array}{l}\text { Goede kwaliteit van het } \\
\text { lesmateriaal }\end{array}$ & 404 & $80 \%$ & 45 & $9 \%$ & 160 & $80 \%$ & 51 & $88 \%$ & 57 & $74 \%$ & 82 & $85 \%$ & 54 & $74 \%$ \\
\hline $\begin{array}{l}\text { Schriftelijk materiaal } \\
\text { was geschikt voor } \\
\text { zelfstandige werkwijze }\end{array}$ & 394 & $78 \%$ & 61 & $12 \%$ & 151 & $76 \%$ & 44 & $76 \%$ & 658 & $84 \%$ & 79 & $82 \%$ & 557 & $75 \%$ \\
\hline Tevreden over & $(\mathrm{n}=25$ & 51) & & & & & $(n=4$ & & $(n=7$ & 76) & $(n=7$ & 73) & $(n=5$ & 53) \\
\hline stageplaats & 195 & $78 \%$ & 38 & $15 \%$ & & & 39 & $80 \%$ & 607 & $79 \%$ & 53 & $73 \%$ & 438 & $84 \%$ \\
\hline $\begin{array}{l}\text { Niveau vaktheoretisch } \\
\text { gedeelte is goed } \cdots\end{array}$ & 418 & $83 \%$ & 49 & $10 \%$ & 186 & $93 \%$ & 46 & $79 \%$ & 577 & $74 \%$ & 80 & $82 \%$ & 49 & $67 \%$ \\
\hline $\begin{array}{l}\text { Tempo vaktheoretisch } \\
\text { gedeelte is goed }\end{array}$ & 373 & $74 \%$ & $\begin{array}{l}92 \\
\text { te he } \\
\text { te la }\end{array}$ & $\begin{array}{l}18 \% \\
\log 27 \\
\arg 65\end{array}$ & $7^{159}$ & $80 \%$ & 43 & $74 \%$ & 486 & $62 \%$ & 73 & $75 \%$ & 50 & $68 \%$ \\
\hline $\begin{array}{l}\text { Voldoende begeleiding } \\
\text { tijdens de lessen } . *\end{array}$ & 409 & $81 \%$ & 46 & $9 \%$ & 176 & $88 \%$ & 46 & $79 \%$ & 51 & $66 \%$ & 76 & $78 \%$ & 60 & $82 \%$ \\
\hline $\begin{array}{l}\text { Stof goed kunnen } \\
\text { overbrengen }{ }^{-"}\end{array}$ & 402 & $80 \%$ & 49 & $10 \%$ & 170 & $85 \%$ & 47 & $81 \%$ & 587 & $75 \%$ & 77 & $79 \%$ & 50 & $68 \%$ \\
\hline
\end{tabular}

De categorieên neutraal en oneens zijn in deze tabel (gedeeltelijk) niet weergegeven

*. $\quad 0.001<p \leq 0.01$

$\cdots p=0.001$

Indien wordt gekeken naar verschillen tussen de centra blijken de oud-cursisten van Hoensbroeck relatief meer tevreden over de aandacht die wordt geschonken aan de theorie $\left(\mathrm{chi}^{2}=26.3, \mathrm{p}<0.001\right)$. Ten aanzien van de praktijkcomponent blijken met name de oud-cursisten van Heliomare hierover relatief minder tevreden te zijn. Dit in 
tegenstelling tot de oud-cursisten van Hoensbroeck en Werkenrode, die relatief meer tevreden zijn over de aandacht die aan de praktijkcomponent wordt geschonken $\left(\mathrm{chi}^{2}=\right.$ 27.6, $p<0.001$ ). Er bestaan tussen de oud-cursisten van de vijf centra vrijwel geen verschillen van mening over het lesmateriaal, zijnde de praktijkapparatuur, en het schriftelijk lesmateriaal. De oud-cursisten van EEGA zijn relatief minder tevreden over het niveau van de opleiding, waar de oud-cursisten van Hoensbroeck in het algemeen meer tevreden zijn over het niveau van de vaktheoretische component $\left(\mathrm{chi}^{2}=35.9, \mathrm{p}<\right.$ 0.001 ). Voor wat betreft het tempo worden vrijwel geen onderlinge verschillen geconstateerd.

Een ruime meerderheid van de oud-cursisten is tevreden over de werkwijze van de docenten (tabel 4.5 ). Ze zijn van mening dat de docenten voldoende begeleiden tijdens de lessen $(81 \%)$ en de stof goed kunnen overbrengen $(80 \%)$. Wanneer wordt gekeken naar verschillen op centrumniveau, blijken met name de oud-cursisten van Sonneheerdt relatief minder tevreden te zijn over de begeleiding tijdens de lessen (chi ${ }^{2}$ $=21.5, \mathrm{p}<0.01$ ). De oud-cursisten van EEGA zijn relatief minder positief over de mate waarin de docenten de stof goed kunnen overbrengen $\left(\mathrm{chi}^{2}=13.5, \mathrm{p}<0.10 \mathrm{~ms}\right.$ ).

\section{Waardering ondersteunings- en begeleidingsgedeelte}

Uit de interviews met docenten, professionals en leidinggevenden komt naar voren dat de reïntegratie centra diverse vormen van ondersteuning en begeleiding in hun programma hebben opgenomen, namelijk studiebegeleiding, psycho-sociale begeleiding, (para)medische begeleiding, en (alleen Werkenrode) begeleiding in de woonsituatie ${ }^{8}$.

Vierhonderd cursisten (79\%) hebben studiebegeleiding na de lessen gehad, 426 cursisten ( $85 \%$ ) hebben psycho-sociale begeleiding gekregen en $137(27 \%)$ cursisten hebben aangegeven gebruik te hebben gemaakt van (para)medische begeleiding (tabel 4.6). Dat geeft aan dat de door de professionals genoemde begeleidingsvormen worden aangeboden en er door de cursisten gebruik van wordt gemaakt.

Bijna twee derde deel van de oud-cursisten die studiebegeleiding na de lessen hebben gehad, geeft aan deze studiebegeleiding als voldoende te hebben ervaren $(63 \%)$. Een kwart van deze groep $(23 \%)$ heeft deze studiebegeleiding als onvoldoende ervaren. Van de oud-cursisten die psycho-sociale begeleiding hebben gekregen $(n=426)$, is ongeveer driekwart van de oud-cursisten ( $72 \%)$ tevreden over deze begeleiding.

3. De gegevens omtrent de begeleiding in de woonsituatie zullen niet apart worden genoemd, aangerien dere alleen van toepassing zijn op de situatic binnen Werkenrode. 
Tabel 4.6 Mening oud-cursisten over begeleidingsaspecten ( $\mathrm{n}=504)$. Aantallen en percentages.

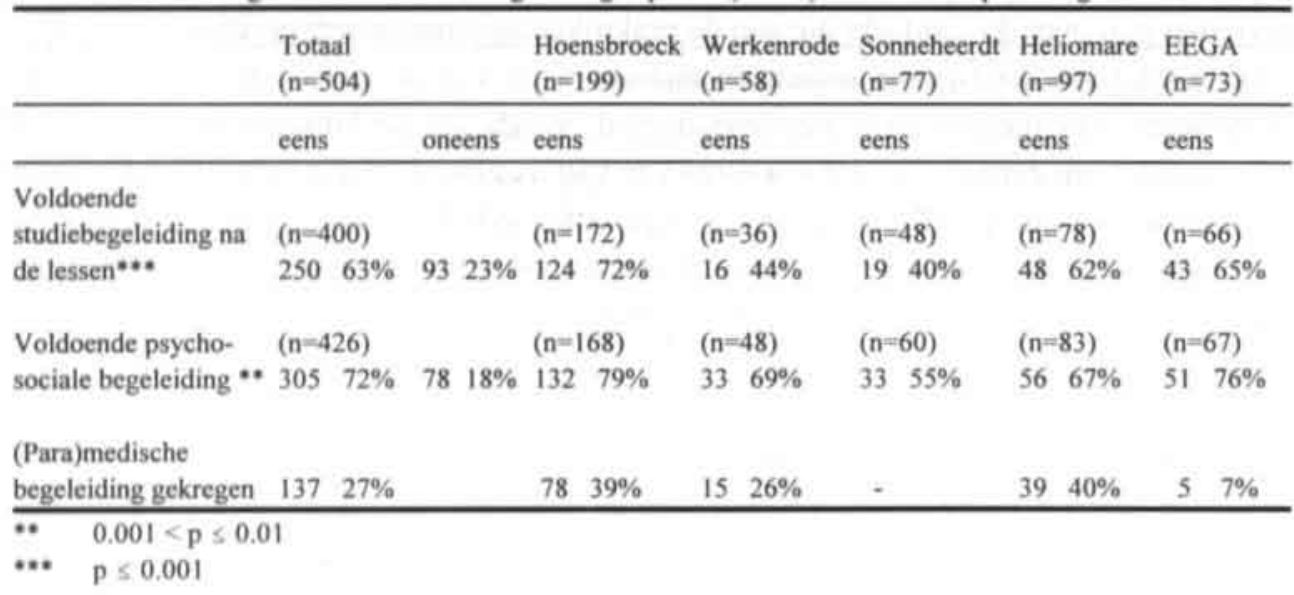

De oud-cursisten van Werkenrode en Sonneheerdt zijn ten opzichte van de overige reïntegratiecentra relatief minder tevreden over de studiebegeleiding na de lessen ( $\mathrm{chi}^{2}$ $=29.4, p<0.001)$. De oud-cursisten van EEGA en Hoensbroeck zijn relatief meer tevreden over de psycho-sociale begeleiding, waar de oud-cursisten van Sonneheerdt relatief minder tevreden zijn over deze begeleidingsvorm $\left(\mathrm{chi}^{2}=39.3, \mathrm{p}<0.01\right)$. Ongeveer een kwart van de oud-cursisten geeft aan (para)medische begeleiding te hebben gekregen. Tussen de centra onderling bestaan verschillen, de oud-cursisten van Hoensbroeck en Heliomare hebben relatief in gelijke mate gebruik gemaakt van de (para)medische begeleiding, de oud-cursisten van EEGA makten relatief weinig gebruik van de aanwezige (para)medische begeleiding. Het geringe gebruik kan niet geheel worden verklaard door het relatief groot aantal cursisten met psychische problematiek.

\section{Bemiddeling naar arbeid}

Uit de interviews met docenten, leidinggevenden en professionals blijkt dat relatief weinig aandacht wordt besteed aan directe bemiddeling. Derhalve is geïnformeerd in hoeverre de oud-cursisten beroepsgerichte trainingen hebben gevolgd, begeleiding hebben gekregen (in algemene zin) bij het vinden van een baan en ondersteuning hebben ervaren na het scholingsprogramma. Van de oud-cursisten geeft $77 \%(n=389)$ aan beroepsgerichte trainingen te hebben gevolgd, $69 \%$ van de oud-cursisten ( $n=351$ ) heeft begeleiding gekregen bij het vinden van een baan en $64 \% \quad(n=321)$ heeft ondersteuning ervaren nadat het scholingsprogramma is afgerond (zie tabel 4.7). 
De aandacht die aan deze indirecte bemiddelingsactiviteiten is besteed, verschilt per reinntegratiecentrum. In tegenstelling tot de overige reïntegratiecentra geven vrijwel alle oud-cursisten van Hoensbroeck en Werkenrode aan beroepsgerichte trainingen te hebben gevolgd $\left(\left(\mathrm{chi}^{2}=85.5, \mathrm{p}<0.001\right)\right.$. Ten aanzien van het krijgen van begeleiding van een baan, wijken de oud-cursisten van Heliomare af van het gemiddelde; de helft van de oud-cursisten van Heliomare geeft aan begeleiding te hebben gekregen bij het verwerven van een baan $\left(\mathrm{chi}^{2}=30.3, \mathrm{p}<0.001\right)$. Driekwart van de oud-cursisten van Sonneheerdt heeft ondersteuning ervaren na afronding van het scholingsprogramma en de helft van de oud-cursisten van Heliomare kreeg ondersteuning. Bij de overige reìntegratiecentra geeft $66 \%$ van de oud-cursisten aan ondersteuning na afronding van het scholingsprogramma te hebben gekregen $\left(\mathrm{chi}^{2}=13.2, \mathrm{p}<0.01\right)$. De in deze paragraaf genoemde cijfers zijn te herleiden uit tabel 4.7.

\section{Bijdrage scholingsprogramma aan de voorbereiding op de arbeidsmarkt}

Aan de oud-cursisten is gevraagd in hoeverre de diverse onderdelen van het scholingsprogramma hebben bijgedragen aan een goede voorbereiding op de arbeidsmarkt (tabel 4.7). Hierbij wordt een onderscheid gemaakt tussen het theoretisch gedeelte, het praktijkgedeelte en de begeleidings- en ondersteuningscomponent. Tevens wordt daarbij de studiebegeleiding, de psycho-sociale begeleiding en de bemiddelingscomponent meegenomen. Met betrekking tot de bemiddelingscomponent kunnen verschillende aspecten worden onderscheiden, te weten de beroepsgerichte trainingen (zoals onder meer sollicitatietraining), de begeleiding bij het vinden van een baan en de ondersteuning na de opleiding.

Meer dan driekwart van de oud-cursisten is van mening dat het vakgericht theoretisch gedeelte en het vakgericht praktijkgedeelte in positieve zin hebben bijgedragen aan een goede voorbereiding op de arbeidsmarkt (respectievelijk $78 \%$ en $83 \%$ ). Ten aanzien van de beroepsgerichte trainingen vindt ongeveer de helft van de oud-cursisten die deze trainingen gevolgd hebben, dat ze een positieve bijdrage hebben geleverd aan de voorbereiding op de arbeidsmarkt ( $49 \%$ ).

Indien wordt gekeken naar verschillen op centrumniveau, blijken met name de oudcursisten van EEGA minder tevreden te zijn over de bijdrage van het vakgericht theoretisch gedeelte en het vakgericht praktijkgedeelte (respectievelijk chi $^{2}=15.7$, $\mathrm{p}<0.01$ en chi $^{2}=25.1, \mathrm{p}<0.001$ ). Er bestaat bij de oud-cursisten van de verschillende centra vrijwel geen verschil van mening over de bijdrage van de beroepsgerichte trainingen aan de voorbereiding op de arbeidsmarkt. 
Een klein deel van de oud-cursisten is van mening dat de begeleiding bij het vinden van een baan en de ondersteuning na het scholingsprogramma in positieve zin hebben bijgedragen aan een goede voorbereiding op de arbeidsmarkt (respectievelijk $31 \%$ en $25 \%$ ). Zoals reeds eerder vermeld wordt deze begeleiding vrijwel alleen op indirecte wijze aangeboden. Mogelijk zijn de uitingsvormen van deze begeleiding als zodanig niet herkend door de oud-cursisten. Het is eveneens mogelijk dat andere onderdelen van het scholingsprogramma een relatief grotere bijdrage hebben geleverd aan een goede voorbereiding op de arbeidsmarkt.

Tabel 4.7 Mening oud-cursisten betreffende de bijdrage van het vakgericht theoretisch gedeelte, het vakgericht praktijkgedeelte, studiebegeleiding, psycho-sociale begeleiding, beroepsgerichte trainingen, alsmede de begeleiding bij het vinden van een baan en de ondersteuning na de opleiding aan de voorbereiding op de arbeidsmarkt. Aantallen en percentages

\begin{tabular}{|c|c|c|c|c|c|c|c|c|}
\hline & Totaal & & & $\begin{array}{l}\text { Hoensbroeck } \\
(n=199)\end{array}$ & $\begin{array}{l}\text { Werkenrode } \\
(n=58)\end{array}$ & $\begin{array}{l}\text { Sonneheerdt } \\
(\mathrm{n}=77)\end{array}$ & $\begin{array}{l}\text { Heliomare } \\
(\mathrm{n}=97)\end{array}$ & $\begin{array}{l}\text { EEGA } \\
(n=73)\end{array}$ \\
\hline & eens & onee & & eens & eens & eens & eens & eens \\
\hline Vakgericht & $(n=474)$ & & & $(n=193)$ & $(n=54)$ & $(n=75)$ & $(\mathrm{n}=86)$ & $(\mathrm{n}=66)$ \\
\hline theoretische gedeelte & $37078 \%$ & 104 & $22 \%$ & $16284 \%$ & $42 \quad 78 \%$ & $5979 \%$ & $6778 \%$ & $40 \quad 61 \%$ \\
\hline Vakgericht & $(n=468)$ & & & $(n=193)$ & $(n=54)$ & $(n=75)$ & $(n=80)$ & $(n=66)$ \\
\hline praktijkgedeelte & $38683 \%$ & 82 & $17 \%$ & $16887 \%$ & $51 \quad 94 \%$ & $6283 \%$ & $6379 \%$ & $4264 \%$ \\
\hline & $(n=400)$ & & & $(\mathrm{n}=198)$ & $(\mathrm{n}=56)$ & $(n=74)$ & & $(n=72)$ \\
\hline Studiebegeleiding' & $17243 \%$ & 120 & $30 \%$ & $9146 \%$ & $25 \quad 45 \%$ & $25 \quad 34 \%$ & & $31 \quad 43 \%$ \\
\hline Psycho-sociale & $(n=428)$ & & & $(n=199)$ & $(n=56)$ & $(n=74)$ & $(\mathrm{n}=8)$ & $(n=11)$ \\
\hline begeleiding' • & $66 \quad 15 \%$ & 100 & $23 \%$ & $4121 \%$ & $59 \%$ & $1014 \%$ & $675 \%$ & $436 \%$ \\
\hline Beroepsgerichte & $(n=389)$ & & & $(\mathrm{n}=191)$ & $(n=48)$ & $(n=54)$ & $(n=52)$ & $(n=44)$ \\
\hline trainingen $\cdots$ & $19349 \%$ & 196 & $51 \%$ & $8947 \%$ & $30 \quad 63 \%$ & $2241 \%$ & $3262 \%$ & $20 \quad 46 \%$ \\
\hline Begeleiding bij een & $(\mathrm{n}=351)$ & & & $(n=156)$ & $(\mathrm{n}=43)$ & $(n=60)$ & $(n=51)$ & $(n=41)$ \\
\hline baan vinden $\cdots$ & $10831 \%$ & 243 & $69 \%$ & $3422 \%$ & $1535 \%$ & $2542 \%$ & $1529 \%$ & $1946 \%$ \\
\hline Ondersteuning na de & $(n-321)$ & & & $(n=135)$ & $(\mathrm{n}=38)$ & $(n=57)$ & $(n=50)$ & $(n=41)$ \\
\hline opleiding $*$ & $8225 \%$ & 239 & $75 \%$ & $2015 \%$ & $924 \%$ & $2035 \%$ & $1836 \%$ & $1537 \%$ \\
\hline
\end{tabular}

1 voor een aantal oud-cursisten zijn deze vragen niet van toepassing.

Eens: wel bijgedragen aan de voorbereiding op de arbeidsmarkt

Oneens: weinig tot niet bijgedragen aan de voorbereiding op de arbeidsmarkt

- $0.01<p \leq 0.05$

$\because \quad 0.001<p<0.01$

$\cdots$ p $\leqslant 0.001$ 
Voor wat betreft de begeleiding bij het vinden van een baan in relatie tot de voorbereiding op de arbeidsmarkt vinden met name de oud-cursisten van Sonneheerdt dat deze begeleiding heeft bijgedragen aan een goede voorbereiding op de arbeidsmarkt. De oud-cursisten van Hoensbroeck zijn het hier relatief minder mee eens $\left(\mathrm{chi}^{2}=14.3, \mathrm{p}<0.01\right)$. De oud-cursisten van Hoensbroeck zijn eveneens relatief minder positief over de ondersteuning in de werksituatie na afloop van het gevolgde reïntegratietraject $\left(\mathrm{chi}^{2}=16.4, \mathrm{p}<0.01\right)$.

Twee derde deel van de oud-cursisten van mening dat ze door het volgen van het scholingsprogramma betere vooruitzichten op de arbeidsmarkt hebben gekregen.

Tenslotte is een grote meerderheid van de oud-cursisten $(82 \%)$ tevreden met hun toenmalige beslissing om een scholingsprogramma te volgen en $61 \% \mathrm{zou}$, indien ze opnieuw voor de keuze zouden staan, wederom een dergelijk programma willen volgen (tabel 4.8). Tussen de reïntegratiecentra onderling bestaat bij de oud-cursisten geen verschil van mening ten aanzien van de tevredenheid met de toenmalige beslissing en het wederom wensen te volgen van een vergelijkbaar scholingsprogramma.

Tabel 4.8 Mening oud-cursisten over de tevredenheid met toenmalige beslissing en de mate waarin wederom zou worden gekozen een dergelijk scholingsprogramma te volgen $(n=504)$.

Aantallen en percentages

\begin{tabular}{|c|c|c|c|c|c|c|c|c|c|c|c|c|c|}
\hline & \multicolumn{3}{|c|}{ Totaal $(n=504)$} & \multicolumn{2}{|c|}{$\begin{array}{l}\text { Hoensbroeck } \\
(n=199)\end{array}$} & \multicolumn{2}{|c|}{$\begin{array}{l}\text { Werkenrode } \\
(\mathrm{n}=58)\end{array}$} & \multicolumn{2}{|c|}{$\begin{array}{l}\text { Sonneheerdt } \\
(\mathrm{n}=77)\end{array}$} & \multicolumn{2}{|c|}{$\begin{array}{l}\text { Heliomare } \\
(n=97)\end{array}$} & \multicolumn{2}{|c|}{$\begin{array}{l}\text { EEGA } \\
(n=73)\end{array}$} \\
\hline & eens & onee & & eens & & een: & & eens & & eens & & een & \\
\hline toenmalige beslissing & 414 & $82 \% 64$ & $13 \%$ & 173 & $87 \%$ & 44 & $78 \%$ & 60 & $78 \%$ & 82 & $87 \%$ & 55 & $76 \%$ \\
\hline Weer scholing volgen & 309 & $61 \% 160$ & $32 \%$ & 130 & $66 \%$ & 34 & $60 \%$ & 36 & $47 \%$ & 66 & $70 \%$ & 43 & $61 \%$ \\
\hline
\end{tabular}

Samenvattend zijn de oud-cursisten in het algemeen tevreden over de vorm en inhoud van het vaktheoretisch gedeelte van de scholingsprogramma's. De beroepsgerichte scholing geeft voldoende aandacht aan theorie en praktijk. Naar de mening van de oudcursisten heeft het vakgericht theoretisch gedeelte en het vakgericht praktijkgedeelte bijgedragen aan een goede voorbereiding op de arbeidsmarkt.

De tevredenheid over de individuele benadering is te herkennen aan de positieve reacties op het tempo en niveau van het scholingsprogramma, de mening over het zelfstandig kunnen werken met het lesmateriaal alsmede de tevredenheid over de aanwezigheid van voldoende praktijkapparatuur. 
Tussen de centra onderling verschillen de oud-cursisten van mening over de verdeling theorie - praktijk, het niveau van het scholingsprogramma, de begeleiding tijdens de lessen en de didactische kwaliteiten van de docenten.

Een groot aantal oud-cursisten heeft ondersteuning gekregen in de vorm van studiebegeleiding en psycho-sociale begeleiding en is daar in het algemeen tevreden over. Een kwart van de oud-cursisten heeft gebruik gemaakt van (para)medische begeleiding. De oud-cursisten van de centra verschillen onderling van mening over de mate van tevredenheid over de psycho-sociale begeleiding. Een meerderheid van de oud-cursisten aan indirecte ondersteuning te hebben ervaren bij het zoeken naar werk, hetgeen overeenkomt met de gekozen werkwijze van de centra.

\section{Conclusie}

Ofschoon er verschillen bestaan tussen de centra ten aanzien van de waardering van de diverse - volgens de literatuur relevante - componenten van de scholingsprogramma's, kan worden gesteld dat de oud-cursisten in hoge mate tevreden zijn over de vorm en inhoud van de scholingsprogramma's en dat in die zin er sprake is van een goede matching tussen de aangeboden scholingsprogramma's en de persoonlijke interesses, capaciteiten en (on)mogelijkheden van de oud-cursisten. 


\section{RESUltaten: PARTICIPATIE}

De mate van participatie wordt met behulp van drie factoren gemeten, namelijk persoonlijke ontwikkeling, plaatsing op korte en/of lange termijn en het functioneren in de werksituatie. Deze drie factoren zijn te herkennen in de derde onderzoeksvraag, waarop in dit hoofdstuk antwoord wordt gegeven, namelijk:

3 In hoeverre leidt het volgen van een langdurig scholingsprogramma tot succes, geconcretiseerd in een toename in de persoonlijke ontwikkeling, plaatsing op de reguliere arbeidsmarkt en succesvol functioneren in de werksituatie?

In paragraaf $5.1 \mathrm{zal}$ de door de oud-cursisten ervaren persoonlijke ontwikkeling worden beschreven. Vervolgens zal in paragraaf 5.2 het plaatsingsproces worden beschreven, waarbij gebruik wordt gemaakt van de gegevens afkomstig uit de telefonische survey met oud-cursisten en van de gegevens afkomstig uit de face to face interviews met leidinggevenden, die oud-cursisten in dienst hebben genomen. In paragraaf 5.3 wordt ingegaan op de derde factor, het functioneren in de werksituatic. Hierbij is uitsluitend gebruik gemaakt van gegevens afkomstig uit de face to face interviews. Ter illustratie van de bevindingen zullen citaten uit de interviews worden gebruikt.

\subsection{PERSOONLIJKE ONTWIKKELING}

De oud-cursisten is gevraagd in hoeverre naar hun idee het scholingsprogramma heeft bijgedragen aan de persoonlijke ontwikkeling, blijkend uit een toegenomen zelfvertrouwen, het beter kunnen omgaan met hun ziekte/beperking, betere sociale

De in dit hoofdstuk beschreven resultaten zijn deels cerder gepubliceerd in:

Lierop. B. van \& Nijhuis, F, (2000). Assessment, education and placernent: an integrated approach to vocational rehabilitation. International Journal of Rehabilitation Rescarch, 23, 261-269.

Nijhuis, F.J.N. \& Lebesque-van Lierop, B.A.G. (1999). Disability managenent. Een integrale benadering van arbeids(re)integratic. Gedrag en Organisatie: Tijduchrift voor sociale, arbeids en organisatic-psychologic, 12, 6, 413. 426. 
vaardigheden, een groter incasseringsvermogen en een beter functioneren op de arbeidsmarkt (tabel 5.1).

Het merendeel van de oud-cursisten is van mening dat het volgen van een scholingsprogramma heeft bijgedragen aan een stijging van hun zelfvertrouwen (79\%). Iets meer dan de helft vindt dat ze doordat ze het scholingsprogramma hebben gevolgd, beter kunnen omgaan met hun ziekte en/of beperkingen ( $55 \%$ ).

Ongeveer twee derde van de cursisten geeft aan dat ze door het volgen van het reïntegratietraject over meer sociale vaardigheden beschikken $(60 \%)$ en dat hun incasseringsvermogen is vergroot $(63 \%)$.

Tabel 5.1 Mening oud-cursisten over de bijdrage van het volgen van een reîntegratietraject aan cen aantal aspecten van de persoonlijke ontwikkeling $(n=504)$. Aantallen en percentages

\begin{tabular}{|c|c|c|c|c|c|c|c|c|c|c|c|c|c|c|}
\hline & \multicolumn{4}{|c|}{ Totaal $(n=504)$} & \multicolumn{2}{|c|}{$\begin{array}{l}\text { Hoensbroeck } \\
(n=199)\end{array}$} & \multicolumn{2}{|c|}{$\begin{array}{l}\text { Werkenrode } \\
(\mathrm{n}=58)\end{array}$} & \multicolumn{2}{|c|}{$\begin{array}{l}\text { Sonneheerdt } \\
(\mathrm{n}=77)\end{array}$} & \multicolumn{2}{|c|}{$\begin{array}{l}\text { Heliomare } \\
(\mathrm{n}=97)\end{array}$} & \multicolumn{2}{|c|}{$\begin{array}{l}\text { EEGA } \\
(n=73)\end{array}$} \\
\hline & eens & & onee & & eens & & een: & & eens & & een & & een & \\
\hline Zelfvertrouwen & 397 & $79 \%$ & 107 & $21 \%$ & 166 & $83 \%$ & 44 & $76 \%$ & 55 & $71 \%$ & 75 & $77 \%$ & 57 & $78 \%$ \\
\hline \multicolumn{15}{|l|}{ Omgaan met } \\
\hline ziekte/beperkingen & 279 & $55 \%$ & 225 & $45 \%$ & 106 & $53 \%$ & 36 & $62 \%$ & 38 & $49 \%$ & 60 & $62 \%$ & 39 & $53 \%$ \\
\hline Sociale vaardigheden & 301 & $60 \%$ & 203 & $40 \%$ & 120 & $60 \%$ & 37 & $64 \%$ & 43 & $56 \%$ & 55 & $57 \%$ & 46 & $63 \%$ \\
\hline Incasseringsvermogen & 318 & $63 \%$ & 186 & $37 \%$ & 134 & $67 \%$ & 35 & $60 \%$ & 44 & $57 \%$ & 58 & $60 \%$ & 47 & $64 \%$ \\
\hline $\begin{array}{l}\text { Functioneren op de } \\
\text { arbeidsmarkt } * *\end{array}$ & 352 & $70 \%$ & 114 & $23 \%$ & 157 & $79 \%$ & 39 & $70 \%$ & 45 & $59 \%$ & 66 & $70 \%$ & 45 & $64 \%$ \\
\hline
\end{tabular}

Eens: $\quad$ scholingsprogramma heeft wel bijgedragen aan dit aspect van de persoonlijke ontwikkeling

Oneens: scholingsprogramma heeft weinig tot niet bijgedragen aan dit aspect van de persoonlijke ontwikkeling

*. $\quad 0.001<p \leq 0.01$ (niet van tocpassing: $n=68$ )

De oud-cursisten van de vijf centra verschillen onderling niet of nauwelijks in hun oordeel over de bijdrage van het scholingsprogramma aan de verschillende aspecten van de persoonlijke ontwikkeling.

Van de oud-cursisten is $70 \%$ van mening dat ze door het volgen van een scholingsprogramma beter kunnen functioneren op de arbeidsmarkt. Hierin onderscheidt Hoensbroeck zich op een positieve wijze en Sonneheerdt op een minder positieve wijze. Een relatief groot aantal oud-cursisten van Hoensbroeck en een relatief kleiner aantal cursisten van Sonneheerdt geeft aan door de scholing beter te kunnen functioneren op de arbeidsmarkt $\left(\mathrm{chi}^{2}=19.6, \mathrm{p}<0.01\right)$. 
Samenvattend kan worden gesteld dat er een toename is in de persoonlijke ontwikkeling van de cursisten die een scholingsprogramma hebben doorlopen. Het merendeel van de oud-cursisten legt hierbij een duidelijk verband tussen het volgen van het scholingsprogramma en het bij henzelf geconstateerde toegenomen zelfvertrouwen, het beter kunnen omgaan met hun ziekte en/of beperkingen, de toegenomen sociale vaardigheden, een groter incasseringsvermogen en het beter kunnen functioneren op de arbeidsmarkt.

Een relatie leggen tussen de in dit onderzoek gevonden resultaten en resultaten uit eerder onderzoek is vrijwel niet mogelijk omdat bij de bestudeerde evaluaties van reïntegratieprogramma's de persoonlijke ontwikkeling vrijwel nooit als output variabele is opgenomen. Alleen Brejc (1994) constateert in een evaluatiestudie naar intensieve reïntegratieprogramma's dat na afloop ervan een verbetering optreedt in de sociale participatie van deelnemers aan dergelijke programma's. Deze uitkomst is vergelijkbaar met de hier gevonden resultaten.

\subsection{PLAATSING}

In de laatste alinea van de vorige paragraaf wordt opgemerkt dat persoonlijke ontwikkeling vrijwel nooit als maat voor uitkomstvariabele in evaluatie onderzoek naar reïntegratieprogramma's wordt meegenomen. In de meeste gevallen beperken de resultaten van evaluatie onderzoek zich tot het melden van de plaatsingscijfers, zonder gegevens te melden omtrent de wijze waarop de baan wordt gevonden, mogelijke werkvormen, benodigde aanpassingen en gegevens omtrent de verworven inkomsten (Gogstadt, 1968; Cook, 1983; Morgan \& O'Connell, 1987; Crepeau \& Scherzer, 1993; Wilgosh \& Muller, 1993; Brejc, 1994; Hennessey \& Muller, 1995; Schmidt et al., 1995; Selander et al., 1998; Ellison et al., 1999; Kirschenbaum, 1999).

Uitgaande van de uitgangssituatie van de cursistenpopulatie, namelijk volledige arbeidsongeschiktheid, is de vraag in hoeverre deze situatie na het volgen van een scholingsprogramma is veranderd. Hiervoor, maar ook omdat inzicht in het plaatsingsproces mogelijk nieuwe informatie genereert omtrent factoren voor succesvolle participatie, zijn gegevens omtrent wijze van baan vinden, werkvormen, aanpassingen en inkomen in dit onderzoek wel meegenomen. Bij de plaatsingscijfers wordt tevens een relatie gelegd tussen het gevolgde scholingsprogramma en plaatsingsresultaat. 


\subsubsection{Plaatsing op korte termijn}

In totaal geeft $71 \%$ van de oud-cursisten aan binnen 12 maanden na afronding van de opleiding een betaalde baan te hebben gevonden (tabel 5.2). Onderling verschillen de centra niet met betrekking tot het aantal cursisten dat binnen twaalf maanden na afronding van het reīntegratietraject een baan vindt. Deze resultaten bevestigen eerdere onderzoeksbevindingen (zie paragraaf 2.1.2) dat intensieve, brede scholingsprogramma's een positieve invloed hebben op de reïntegratiekans. Deze uitkomst is aanzienlijk positiever dan de uitkomsten zoals die bekend zijn uit het onderzoek van Molenaar-Cox en Prins (1998), waarbij 19\% van de onderzochte arbeidsgemotiveerde arbeidsgehandicapten één jaar na (volledige of gedeeltelijke) arbeidsongeschiktheidsverklaring, werkzaam is bij een nieuwe werkgever.

Tabel 5.2 Weergave van op korte termijn geplaatste oud-cursisten totaal en per reîntegratiecentrum, verdeeld over de vakrichtingen. Resultaat per vakrichting weergegeven als \% van het aantal afgestudeerden.

\begin{tabular}{|c|c|c|c|c|c|c|c|c|c|c|c|c|c|}
\hline \multirow{2}{*}{$\begin{array}{l}\text { Periode tussen } \\
\text { scholing en werk in } \\
\text { maanden (sd) }\end{array}$} & \multicolumn{3}{|l|}{$\begin{array}{l}\text { Totaal } \\
(n=504)\end{array}$} & \multicolumn{2}{|c|}{$\begin{array}{l}\text { Hoensbroeck } \\
(n=199)\end{array}$} & \multicolumn{2}{|c|}{$\begin{array}{l}\text { Werkenrode } \\
(n=58)\end{array}$} & \multicolumn{2}{|c|}{$\begin{array}{l}\text { Sonneheerdt } \\
(\mathrm{n}=77)\end{array}$} & \multicolumn{2}{|c|}{$\begin{array}{l}\text { Heliomare } \\
(\mathrm{n}=97)\end{array}$} & \multicolumn{2}{|c|}{$\begin{array}{l}\text { EEGA } \\
(n=73) \\
\end{array}$} \\
\hline & \multicolumn{3}{|c|}{$2.4(3.3)$} & 2.9 & (3.3) & 1.4 & (2.9) & 2.2 & (3.0) & 1.9 & $(3.2)$ & 2.4 & (3.5) \\
\hline & richting & \multicolumn{2}{|c|}{ werk } & \multicolumn{2}{|c|}{ werk } & \multicolumn{2}{|c|}{ werk } & \multicolumn{2}{|c|}{ werk } & \multicolumn{2}{|c|}{ werk } & \multicolumn{2}{|c|}{ werk } \\
\hline Administratie & 219 & 150 & $68 \%$ & 50 & $72 \%$ & 19. & $76 \%$ & 21 & $63 \%$ & 42 & $68 \%$ & 18 & $64 \%$ \\
\hline Informaticbeheer & 66 & 46 & $71 \%$ & 15 & $79 \%$ & & & 8 & $62 \%$ & & & 23 & $71 \%$ \\
\hline Grafische technieken & 50 & 35 & $70 \%$ & & & 21 & $78 \%$ & 3 & $60 \%$ & 11 & $69 \%$ & & \\
\hline Elektrotechnick & 33 & 21 & $64 \%$ & 8 & $47 \%$ & & & 6 & $86 \%$ & 7 & $78 \%$ & & \\
\hline Fietstechniek & 6 & 4 & $67 \%$ & & & & & 4 & $67 \%$ & & & & \\
\hline Pianotechniek & 4 & 3 & $75 \%$ & & & & & 3 & $75 \%$ & & & & \\
\hline Meubelstofferen & 6 & 5 & $83 \%$ & & & & & 5 & $83 \%$ & & & & \\
\hline Tuinbouw & 5 & 4 & $80 \%$ & & & 4 & $80 \%$ & & & & & & \\
\hline Fünmechanica & 17 & 12 & $71 \%$ & 12 & $71 \%$ & & & & & & & & \\
\hline Werktuigbouwk. tek. & 81 & 68 & $84 \%$ & 64 & $83 \%$ & & & & & 4 & $100 \%$ & & \\
\hline Diversen & 17 & 9 & $53 \%$ & 1 & $100 \%$ & & & 2 & $100 \%$ & 2 & $50 \%$ & 4 & $36 \%$ \\
\hline Totaal & 504 & 357 & $71 \%$ & 150 & $75 \%$ & 44 & $76 \%$ & 52 & $68 \%$ & 66 & $68 \%$ & 45 & $62 \%$ \\
\hline
\end{tabular}

Gemiddeld verstrijken tweeëneenhalve maand $(\mathrm{sd}=3.3)$ tussen het beëindigen van de opleiding en het starten in de eerste betaalde baan. De oud-cursisten van Werkenrode vinden gemiddeld ruim één maand ( $\mathrm{sd}=2.9$ ) na afronding van het scholingsprogramma een baan, hetgeen relatief snel is in vergelijking met de cursisten van de andere scholingscentra $(\mathrm{F}=2.6, \mathrm{p}<0.05)$. 
Eerder is aangegeven dat mogelijkerwijs verschil kan bestaan tussen plaatsingskans en vakrichting. Dit blijkt niet het geval, er bestaan vrijwel geen verschillen tussen de door de oud-cursist gevolgde vakrichting en het vinden van een baan op korte termijn.

Aangezien sommige vakrichtingen slechts enkele afgestudeerden kennen, is het niet mogelijk de reìntegratiecentra onderling te vergelijken. Het gering aantal afgestudeerden voor bepaalde vakrichtingen zorgt eveneens voor soms relatief hoge of juist lage plaatsingscijfers. Uitspraken over plaatsingssucces gerelateerd aan vakrichtingen zullen, mede gezien de geringe verschillen per vakrichting, niet worden gedaan.

Ongeveer een kwart van de oud-cursisten $(23 \%)$ geeft aan dat deze cerste baan aansluit bij eerdere beroepservaring. Het percentage oud-cursisten van EEGA dat aangeeft dat deze eerste baan aansluit bij eerdere beroepservaring, ligt hoger dan bij de andere centra $\left(\mathrm{chi}^{2}=8.6, \mathrm{p}<0.05\right)$.

Aan de oud-cursisten is tevens gevraagd in hoeverre de eerste baan aansluit bij het door hen gevolgde scholingsprogramma. Ongeveer tweederde deel van de oudcursisten vindt dat de theorie en de praktijk die ze gevolgd hebben tijdens het scholingsprogramma goed aansluit op de eerste baan (tabel 5.3 ). Gemiddeld is $26 \%$ van de oud-cursisten het hiermee oneens. Eveneens ongeveer tweederde deel van de oud-cursisten $(68 \%)$ is van mening dat ze gelijk of beter zijn 'opgeleid' dan hun collega's. Minder dan een vijfde van de oud-cursisten $(17 \%)$ vindt zichzelf minder goed opgeleid.

Tabel 5.3 Mening oud-cursisten over aansluiting theoretisch en praktisch gedeelte op eerste baan, alsmede opleidingsniveau in vergelijking met collega's ( $n-357)$. Aantallen en percentages '.

\begin{tabular}{|c|c|c|c|c|c|c|c|c|c|c|c|c|c|c|}
\hline \multirow{2}{*}{ Aansluiting theorie op } & \multicolumn{4}{|c|}{$\begin{array}{l}\text { Totaal } \\
(n=357)\end{array}$} & \multicolumn{2}{|c|}{$\begin{array}{l}\text { Hoensbroeck } \\
(n=150)\end{array}$} & \multicolumn{2}{|c|}{$\begin{array}{l}\text { Werkenrode } \\
(n=44)\end{array}$} & \multicolumn{2}{|c|}{$\begin{array}{l}\text { Sonneheerdt } \\
(n-52)\end{array}$} & \multicolumn{2}{|c|}{$\begin{array}{l}\text { Heliomare } \\
(n=66)\end{array}$} & \multicolumn{2}{|c|}{$\begin{array}{l}\text { EEGA } \\
(n=45)\end{array}$} \\
\hline & eens & & one & eens & eens & & eens & & een: & & een: & & een: & \\
\hline baan is goed & 241 & $68 \%$ & 88 & $25 \%$ & 102 & $68 \%$ & 34 & $77 \%$ & 36 & $69 \%$ & 46 & $69 \%$ & 23 & $51 \%$ \\
\hline Aansluiting praktijk op & & & & & & & & & & & & & & \\
\hline $\begin{array}{l}\text { baan is goed } \\
\text { Gelijk of hoger niveau }\end{array}$ & 224 & $63 \%$ & 99 & $28 \%$ & 90 & $61 \%$ & 37 & $84 \%$ & 32 & $62 \%$ & 40 & $61 \%$ & 25 & $56 \%$ \\
\hline dan collega's* & 242 & $68 \%$ & 62 & $17 \%$ & 110 & $73 \%$ & 34 & $77 \%$ & 36 & $69 \%$ & 37 & $56 \%$ & 25 & $56 \%$ \\
\hline
\end{tabular}

De categorie neutraal is in deze tabel niet weergegeven.

- $0.01<p \leq 0.05$ 
De oud-cursisten van de onderzochte reïntegratiecentra verschillen onderling niet in hun mening ten aanzien van de aansluiting van het vakgericht theoretisch gedeelte en het vakgericht praktisch gedeelte van het scholingstraject op de arbeidsmarkt. De oudcursisten van Werkenrode zijn in hun mening over hun niveau van opleiding in vergelijking met collega's meer positief dan de oud-cursisten van de andere reïntegratiecentra $\left(\mathrm{chi}^{2}=12.9, \mathrm{p}<0.05\right)$.

\section{Wijze van baan vinden}

Zoals in paragraaf 4.3 .4 staat beschreven zien de reïntegratiecentra bemiddeling niet als een hoofdtaak omdat wordt gestreefd de cursisten dermate zelfstandig te laten worden dat ze in staat moeten zijn om zelf een baan te vinden en niet afhankelijk hoeven te zijn van de plaatsingsactiviteiten van de reïntegratiecentra. In hoeverre dit streven wordt behaald kan enerzijds worden afgeleid uit de wijze waarop oud-cursisten aangeven een baan te hebben gevonden en anderzijds uit de reacties van werkgevers/ leidinggevenden op de vraag op welke wijze zij aangeven vacatures 'naar buiten' te hebben gebracht.

\section{Het werknemersperspectief}

In tabel 5.4 staat weergegeven op welke wijze de oud-cursisten de eerste baan (binnen twaalf maanden) na afronding van het scholingsprogramma hebben gevonden. Bijna de helft van de oud-cursisten heeft een baan gevonden door te solliciteren op advertenties $(17 \%)$ of via open sollicitaties $(30 \%)$. Bemiddeling via de officiële bemiddelingsinstanties alsmede het verantwoordelijke centrum, heeft bij $26 \%$ van de oud-cursisten een rol gespeeld bij het vinden van de baan. In ongeveer een kwart van de gevallen blijkt de eerste baan voort te vloeien uit een stage.

Tabel 5.4 Wijze waarop de eerste baan na afronding van het reilntegratietraject wordt gevonden $(\mathrm{n}=357)$.

Aantallen en percentages. Meerdere antwoorden zijn mogelijk.

\begin{tabular}{|c|c|c|c|c|c|c|c|c|c|c|c|c|}
\hline \multirow[b]{2}{*}{ Baan vloeide voort uit stage } & \multicolumn{2}{|c|}{$\begin{array}{l}\text { Totaal } \\
(\mathrm{n}=357)\end{array}$} & \multicolumn{2}{|c|}{$\begin{array}{l}\text { Hoensbroeck } \\
(n=150)^{\prime}\end{array}$} & \multicolumn{2}{|c|}{$\begin{array}{l}\text { Werkenrode } \\
(n=44)\end{array}$} & \multicolumn{2}{|c|}{$\begin{array}{l}\text { Sonneheerdt } \\
(n=52)\end{array}$} & \multicolumn{2}{|c|}{$\begin{array}{l}\text { Heliomare } \\
(\mathrm{n}=66)\end{array}$} & \multicolumn{2}{|c|}{$\begin{array}{l}\text { EEGA } \\
(n=45) \\
\end{array}$} \\
\hline & 78 & $22 \%$ & & & 14 & $32 \%$ & 26 & $50 \%$ & 16 & $24 \%$ & 22 & $44 \%$ \\
\hline Terug bij oude werkgever & 13 & $4 \%$ & 6 & $4 \%$ & & & & & 7 & $11 \%$ & & \\
\hline Bemiddeling scholingscentra & 38 & $11 \%$ & 15 & $10 \%$ & 4 & $4 \%$ & 10 & $19 \%$ & 3 & $5 \%$ & 6 & $13 \%$ \\
\hline Bemiddeling Arbvo/UVI & 53 & $15 \%$ & 31 & $21 \%$ & 6 & $14 \%$ & 3 & $6 \%$ & 6 & $9 \%$ & 7 & $16 \%$ \\
\hline Steun sociale omgeving & 32 & $9 \%$ & 14 & $9 \%$ & 4 & $9 \%$ & 5 & $10 \%$ & 6 & $9 \%$ & 3 & $7 \%$ \\
\hline Solliciteren op advertenties & 60 & $17 \%$ & 37 & $25 \%$ & 5 & $11 \%$ & 6 & $12 \%$ & 11 & $17 \%$ & 1 & $2 \%$ \\
\hline Open sollicitaties & 106 & $30 \%$ & 55 & $37 \%$ & 16 & $36 \%$ & 9 & $17 \%$ & 19 & $29 \%$ & 7 & $16 \%$ \\
\hline Anders & 55 & $15 \%$ & 27 & $18 \%$ & 7 & $16 \%$ & 4 & $8 \%$ & 12 & $19 \%$ & 5 & $11 \%$ \\
\hline
\end{tabular}

Hoensbroeck kent geen stage periode 
Indien wordt gekeken naar verschillen op centrumniveau, blijkt ongeveer tweederde van de oud-cursistenen van Hoensbroeck via 'normale' wegen een baan te hebben gevonden, namelijk via sollicitaties op advertenties of open sollicitaties. Dit geldt voor de helft van de oud-cursisten van Heliomare en Werkenrode, terwijl een gering gedeelte van de oud-cursisten van Sonneheerdt en EEGA een baan heeft gevonden via de 'normale' wegen. Bij ongeveer de helft van de oud-cursisten van de twee laatstgenoemde centra vloeide de baan voort uit de stage. De oud-cursisten van Sonneheerdt vormen relatief de grootste groep die door bemiddeling van het reîntegratiecentrum een baan heeft gevonden. Dit komt overeen met de bevindingen in paragraaf 4.5 .

\section{Het werkgeversperspectief}

Uit de interviews met werkgevers die oud-cursisten in dienst hebben genomen, blijkt een groot deel van de functies die gereīntegreerde werknemers innemen, via een reguliere vacature naar buiten te zijn gebracht en volgens een normale sollicitaticprocedure te zijn verlopen $(59 \%)$. Bekendmaking van de vacature vindt plaats via de krant, maar ook via bekenden. Daarnaast is gebruik gemaakt van het arbeidsbureau, uitzendbureaus, uitvoeringsinstellingen en de scholingscentra. Een klein gedeelte van de gereïntegreerde werknemers blijkt de huidige baan te hebben verkregen via open sollicitaties $(11 \%)$. In enkele gevallen wordt een functie speciaal gecreëerd voor de gereĩntegreerde werknemer ( $5 \%$ ). De wijze waarop de gereïntegreerde werknemers een baan vinden is niet afwijkend van de wijze waarop personen zonder beperkingen en zonder arbeidsongeschiktheidsverleden een baan vinden.

Wg: "De vader van A heeft een relatie met ons, want hij levert ons producten. Hij vroeg of we geen werk hadden voor zijn dochter. Dat is eigenlijk tegen onze principes in, want als je een conflict met de vader hebt, dan merk je dat meteen. Toch konden we niet met goed fatsoen zeggen dat ze niet aangenomen zou worden. Als we op dat moment nee hadden gezegd, dan hadden we een conflict gehad en dat wilden we niet. De afspraak was dat het niet uitmaakte wat ze verdiende, het ging erom dat ze ervaring opdeed. Er was niet eens een vacature, het was duidelijk een verzoek van de vader".

Wg: "Hij is gekozen uit wel tegen de honderd reacties op deze vacature, vanwege de goede, brede opleiding die hij heeft gehad in het reìntegratiecentrum. Hij voldeed gewoon aan de eisen en hij kwam uit de gesprekken als een geschikte kandidaat. Wij dachten dat hij wel goed paste bij ons op de afdeling. Het is een echte specialist die je in huis haalt". 
Ingeval van een vacature via de reguliere wegen is de werknemer gekozen uit gemiddeld drie kandidaten. Ongeveer een kwart van het aantal gereïntegreerde werknemers blijkt de enige kandidaat te zijn geweest, enkele cursisten zijn gekozen uit een groot aantal kandidaten.

Wanneer de antwoorden van de werknemers en werkgevers worden vergeleken, blijkt dat zowel werknemers als werkgevers aangeven dat het merendeel van de banen is verkregen via de reguliere wegen, namelijk openstaande vacatures en open sollicitaties. Bemiddelings-activiteiten vanuit arbeidsvoorziening kunnen eveneens worden gezien als een 'normale' wijze van een baan vinden. Ondanks het feit dat de antwoorden van de werknemers afwijken van de werkgevers vormen de hier getoonde resultaten voldoende basis om te kunnen concluderen dat de doelstelling van de reïntegratiecentra om cursisten zelfstandig een baan te laten vinden, wordt bevestigd.

\section{Werkgeversperspectief: redenen aanname}

Aan werkgevers is gevraagd wat voor hen de doorslaggevende reden is geweest waarom gekozen is voor de betreffende gereinntegreerde werknemer. De helft $(52 \%)$ van de geìnterviewde leiding-gevenden noemt de vakmatige vaardigheden van de werknemer als doorslaggevende factor voor aanname.

Wg: "Het was een reguliere sollicitatie. Ik heb zelf het gesprek gevoerd, het is een open gesprek geweest. Wij hadden op dat moment een bepaalde instelling dat wij ook mensen in een minder kansrijke positie een kans wilden geven op de arbeidsmarkt. In het sollicitatiegesprek heeft hij heel duidelijk aangegeven dat hij een WAO-uitkering had op dat moment en dat hij toch aan het arbeidsproces wilde deelnemen, omdat hij een training, een herscholingscursus had gevolgd. We hebben hem gekozen, gebaseerd op zijn kwaliteiten, op zijn technische kwaliteiten, omdat we hem toch een kans wilden geven".

Eveneens de helft $(52 \%)$ van hen noemt de persoonlijkheid van de bij hun in dienst zijnde werknemer als de doorslaggevende factor. Daarnaast worden het gevoerde handicapbeleid $(24 \%)$ en de voordelen van de geldende wet- en regelgeving $(7 \%)$ genoemd als belangrijke redenen waarom de betreffende werknemer is aangenomen ${ }^{10}$.

10. Hierbij zijn de gecretende functies en de respondenten die hebben aangegeven het niet (meer) te weten. niet mecgenomen. Meerdere antwoorden zijn mogelijk. 
Wg: "Wij zochten een kracht op cen bepaald niveau binnen onze afdeling en toen hebben wij op een gegeven moment te horen gekregen dat zij, afkomstig in feite uit de WAO, op dat niveau werkzaam kon zijn en op grond daarvan hebben wij ze aangenomen. Het was in eerste instantie best wel een moeilijke keuze, want ja, haar achtergrond met betrekking tot de WAO, ja je weet nooit, om even eerlijk te zijn, wat de consequenties daarvan zullen zijn. Anderzijds, toen wij een gesprek zijn aangegaan met haar, toen had ik daar het volste vertrouwen in. Wat we konden inschatten was dat het op dat moment naadloos aansloot met datgene wat we zochten".

Wg: "Z'n karakter, sociale vaardigheden was eigenlijk mee van het belangrijkste waarom wij hem aangenomen hebben. Dat was bij het aannemen het geval en in de praktijk ook nog steeds. Hij geeft ook extra sociaal evenwicht, omdat we overwegend een jong bedrijf zijn met jonge werknemers, zodat hij ook een stukje levenservaring op anderen kan overdragen omdat hij al wat ouder en bovendien ook vader is".

\section{Werknemerspectief: de werkvorm}

Het gegeven dat een oud-cursist werkt, geeft geen inzicht in continuîteit van werk. De werkvorm is hierin mede bepalend. Vrijwel alle oud-cursisten zijn geheel of gedeeltelijk in loondienst (tabel5.5). Bij een klein percentage oud-cursisten geldt dat de eerste baan een speciaal karakter heeft in de zin van subsidiéring dan wel beloning (arbeidspool, WSW of Melkert-baan). Gemiddeld 13\% van de oud-cursisten heeft (gedeeltelijk) een baan via een uitzendbureau. Tussen de scholingscentra bestaan geen verschillen qua werkvorm van de oud-cursisten.

Tabel 5.5 Werkvorm van de eerste baan na afronding van het reintegratietraject. Aantallen en percentages. $\mathrm{n}=357$. Meerdere antwoorden zijn mogelijk.

\begin{tabular}{|c|c|c|c|c|c|c|c|c|c|c|c|c|}
\hline \multirow[b]{2}{*}{ Loondienst } & \multicolumn{2}{|c|}{ Totaal $(n=357)$} & \multicolumn{2}{|c|}{$\begin{array}{l}\text { Hoensbroeck } \\
(n=150)\end{array}$} & \multicolumn{2}{|c|}{$\begin{array}{l}\text { Werkenrode } \\
(\mathrm{n}=44)\end{array}$} & \multicolumn{2}{|c|}{$\begin{array}{l}\text { Sonneheerdt } \\
(n=52)\end{array}$} & \multicolumn{2}{|c|}{$\begin{array}{l}\text { Heliomare } \\
(n=66)\end{array}$} & \multicolumn{2}{|c|}{$\begin{array}{l}\text { EEGA } \\
(n=45)\end{array}$} \\
\hline & 324 & $91 \%$ & 141 & $94 \%$ & 41 & $93 \%$ & 47. & $90 \%$ & 58 & $88 \%$ & 37 & $82 \%$ \\
\hline Zelfstandig ondernemer & 20 & $6 \%$ & 11 & $7 \%$ & 1 & $2 \%$ & 2 & $4 \%$ & 5 & $8 \%$ & 1 & $2 \%$ \\
\hline Uitzendbureau & 45 & $13 \%$ & 18 & $12 \%$ & 5 & $11 \%$ & 6 & $12 \%$ & 9 & $14 \%$ & 7 & $16 \%$ \\
\hline Gesubsidieerde werkvorm & 20 & $6 \%$ & 9 & $6 \%$ & 3 & $7 \%$ & 3 & $6 \%$ & 2 & $3 \%$ & 3 & $7 \%$ \\
\hline Free lance & 21 & $6 \%$ & 11 & $7 \%$ & & & 2 & $4 \%$ & 4 & $6 \%$ & 4 & $9 \%$ \\
\hline WSW & 20 & $6 \%$ & 11 & $7 \%$ & 5 & $11 \%$ & 3 & $6 \%$ & 1 & $2 \%$ & & \\
\hline Overige & 10 & $3 \%$ & 4 & $3 \%$ & 2 & $5 \%$ & I & $2 \%$ & 2 & $3 \%$ & 1 & $2 \%$ \\
\hline
\end{tabular}

\section{Werkgeversperspectief: type en grootte bedrijven}

Uit de interviews met werkgevers die oud-cursisten in dienst hebben genomen blijkt dat $35 \%$ behoort tot de dienstverlenende sector en $23 \%$ tot productiebedrijven/ productieverwerkende bedrijven. Tot de dienstverlenende bedrijven behoren onder 
meer dienstverleners op het gebied van kennis- en informatietechnologie, adviesbureaus en onderhoudsbedrijven. Een klein aantal bedrijven behoort tot de onderwijs en zorgsector $(13 \%)$, grafische sector $(7 \%)$ of handel $(5 \%)$. De overige bedrijven behoren tot diverse sectoren $(9 \%)^{11}$.

Ongeveer een kwart $(28 \%)$ van de bedrijven heeft tot twintig werknemers in dienst. Het aantal middelgrote bedrijven vormt $26 \%$. Bijna de helft van de bedrijven heeft meer dan honderd werknemers in dienst $(46 \%)$, waarbij ongeveer $35 \%$ van deze bedrijven meer dan vijfhonderd werknemers in dienst heeft.

\section{Werkgeversperspectief: cultuur binnen bedrijf ten aanzien van 'handicapbeleid'}

De helft van de ondervraagde bedrijven heeft meerdere werknemers met beperkingen in dienst. De ervaringen met deze werknemers zijn over het algemeen positief tot zeer positief. Een meerderheid van de ondervraagden ( $76 \%$ ) zal het 'handicapbeleid' in de toekomst niet veranderen. De voornaamste reden hiervoor is de positieve ervaring met de huidige werknemers met een arbeidshandicap. Bovendien geeft een groot aantal ondervraagden $(79 \%)$ aan de beperking van ondergeschikt belang te vinden bij gebleken bekwaamheid. Een klein aantal van de ondervraagden $(24 \%)$ zegt een bijdrage te willen leveren aan het arbeidsperspectief van een arbeidsgehandicapte. Eveneens een klein aantal noemt als reden de inachtneming van de wettelijke regelingen $(7 \%)$.

Wg: "Ja, ik wil het liefst alleen maar werken met die mensen. Dat is voor mij ideaal. Geeft meer rust, meer dan al die snelle flitsende yuppies, daar sta ik niet op te wachten".

$\mathrm{Wg}$ : " Ja, ik zou weer iemand aannemen met een arbeidshandicap, omdat het me eigenlijk heel goed is bevallen. Kijk, ik denk niet dat die mensen in een hokje moeten worden gestopt, maar dat iedereen een kans verdient om weer in de arbeidsmarkt productief te kunnen zijn. En ik heb zelf het vermoeden dat die mensen dubbel zo hard gemotiveerd zijn om weer terug te komen op de arbeidsmarkt, en tot dusver heb ik er hele goede ervaringen mee, goede inzet, goede mentaliteit dus".

Enkele werkgevers hebben negatieve ervaringen. Een klein aantal werkgevers (8\%) zou niet nogmaals een werknemer met een arbeidshandicap in dienst nemen vanwege de vaak noodzakelijke extra begeleiding, de kosten die hiermee gepaard gaan en/of de weerstand binnen de organisatie tegen de aanname van mensen met een arbeidshandicap.

11 Missing value $=6(8 \%)$ 
Wg: "Wat ik net al zei, met de WAO ben je soms erg in een hoek gedreven, ik vind het een hele moeilijke kwestie, waar ik in de toekomst nooit meer aan begin. Dat ligt puur aan dat je absoluut niet wordt begeleid".

Wg: "Eerlijk gezegd zou ik niet nog een keer een arbeidsgehandicapte in dienst nemen. Het is ontzettend arbeidsintensief. Er is erg veel weerstand vanuit de organisatic, Van bovenaf niet, die zullen het toejuichen, maar voor de medewerkers en de organisatic is het een extra belasting en tijdsinvestering en die ruimte krijgen we steeds minder door druk van bovenaf. In een tijd van nog meer bezuinigen, nog meer produceren in minder tijd, hebben we ook nog de zorg voor mensen met een handicap. Dat is dan extra zwaar. Door bezuinigingen kan dit bijna niet meer op een acceptabel niveau plaatsvinden".

Meer dan de helft van de ondervraagden heeft in zijn/haar persoonlijke omgeving mensen met een arbeidshandicap. Enkele leidinggevenden geven aan dat de ervaringen uit de directe omgeving met mensen met beperkingen invloed hebben op hun eigen attitude maar ook op hun beleid ten aanzien van het in dienst nemen van arbeidsgehandicapten.

\section{Werkgeversperspectief: kennis van arbeidshandicap}

Aan de gereïntegreerde werknemers zijn geen vragen gesteld in hoeverre zij al dan niet aan hun toekomstige werkgever hebben gemeld dat zij een beperking hebben die mogelijk belemmerend werkt bij het uitvoeren van werkzaamheden. Echter, aan de leidinggevenden is wel gevraagd in hoeverre zij op de hoogte zijn van mogelijk beperkende omstandigheden. Vrijwel alle geïnterviewden (96\%) zijn bij de aanname op de hoogte van de beperkingen van de betreffende werknemer en de hierbij behorende consequenties ${ }^{12}$. Ondanks het feit dat men op de hoogte was van de beperkingen, heeft een aantal werkgevers niets gemerkt van deze beperkingen ( $n=16$. $30 \%$ ). Diegenen die dit wel merkten, geven aan dit vooral te hebben gemerkt door de typische kenmerken van de beperking (rolstoel, blindheid etc.), dan wel doordat de werknemer tijdens het aannamegesprek heeft aangegeven minder inzetbaar te zijn.

Wg: "We merken dagelijks dat hij gehandicapt is. Maar lichamelijk, waar hij op afgekeurd is, is hij minder gehandicapt dan sociaal. Maar dat heeft misschien ook wel met zijn ongeval te maken wat hij heeft gehad".

12 Hierbij zijn de gecrelerde funeties en de respondenten die hebben aangeyeven het niet (meen) le weten, niet mecgenomen. 
Van diegenen die niet op de hoogte zijn van de beperkingen bij aanname, geeft iedereen aan ook niets te hebben gemerkt van mogelijke beperkingen.

Wg: "Op het moment dat hij hier in dienst is getreden, wisten wij dus niks af van zijn arbeidsongeschiktheidsverleden en toen had $i k$ zoiets van, dat is op zich ook niet de manier, natuurlijk. Van de andere kant had het in ieder geval voor mij per definitie niets uitgemaakt of hij een arbeidsongeschikt verleden heeft, ja of nee. Hij blijkt gewoon heel goed in deze functie te kunnen functioneren".

Een meerderheid van de geïnterviewden is op de hoogte van het door de betreffende werknemer gevolgde scholingsprogramma bij een van de erkende scholingscentra $(65 \%)$. Dit betreft vrijwel dezelfde groep respondenten als diegenen die bij aanname op de hoogte zijn van de beperkingen van de betreffende werknemer en de hierbij behorende consequenties.

\section{Werkgeversperspectief: Kennis en toepassing van wettelijke regelingen en instrumenten}

Ten tijde van onderhavig onderzoek is de Wet REA nog niet ingevoerd. Werkgevers hebben derhalve nog geen gebruik kunnen maken van deze nieuwe wet- en regelgeving. In tabel 5.6 staat beschreven in hoeverre de geïnterviewde werkgevers kennis hebben en gebruik maken van de, op de ten tijde van het onderzoek bestaande wettelijke regelingen en instrumenten.

\begin{tabular}{lccc}
\hline Tabel 5.6 & \multicolumn{3}{c}{ Overzicht kennis werkgevers m.b.t. wet- en regelgeving en gebruik ( $\mathrm{n}=75$ ). } \\
\hline Wet- en regelgeving m.b.t. & $\begin{array}{l}\text { Kennis van regeling } \\
\text { (aantallen en } \% \text { ) }\end{array}$ & $\begin{array}{l}\text { Gebruik gemaakt van regeling } \\
\text { (aantallen) }\end{array}$ \\
\hline Proefplaatsing & 24 & $32 \%$ & 15 \\
Loonkostensubsidic & 34 & $45 \%$ & 21 \\
Begeleidingssubsidic & 21 & $28 \%$ & 10 \\
Job-coaching & 18 & $24 \%$ & 5 \\
Loondispensatic & 32 & $43 \%$ & 11 \\
Loonvergoeding bij ziekte & 22 & $29 \%$ & 4 \\
Vergoeding bij aanpassingen & 35 & $47 \%$ & 13 \\
\hline
\end{tabular}

Ongeveer een derde deel van de geĩnterviewde leidinggevenden is op de hoogte van het bestaan van proefplaatsingen. Van degenen die hiervan op de hoogte zijn heeft een 
meerderheid van deze regeling gebruik gemaakt ( $\mathrm{n}=15,62 \%)$. De helft van de ondervraagde werkgevers $(45 \%)$ is op de hoogte van het bestaan van loonkostensubsidie en een groot aantal van hen heeft hier ook gebruik van gemaakt.

De werkgevers die geen gebruik hebben gemaakt van loonkostensubsidie geven hiervoor als reden naar hun zeggen niet hiervoor in aanmerking te komen dan wel geen behoefte te hebben aan zulke regelingen.

Wg: "We waren niet op de hoogte van loonkostensubsidie. Hij heeft ons daarop gewezen. Daar hebben wij dankbaar gebruik van gemaakt. Wij hebben hem een salarisverhoging toegekend".

Wg: "Dat wil ik niet zeggen omdat dat voor ons niet de maatstaf is. Loonkostensubsidies zijn voor ons volstrekt onbelangrijk. Wij vinden dat je kiest. Je stelt een medewerker aan, dat is onze houding en dan is de loonkostensubsidie aardig meegenomen. Als die er geweest is, dan hebben we die gebruikt voor studie of zo, maar verder is dat volstrekt onbelangrijk."

Wg: "Het eerste criterium is de technische functiekwaliteiten van de man of vrouw. Ik zit niet te wachten op loonkostensubsidie. Ik zit te wachten op uitstekend opgeleide MTS'ers".

Een kwart van de ondervraagde respondenten is op de hoogte van begeleidingssubsidie. De helft van deze groep heeft hiervan gebruik gemaakt. De overige werkgevers geven aan uit onwetendheid ten aanzien van de inhoud en betekenis van deze regeling, hiervan geen gebruik te hebben gemaakt. Een enkele werkgever heeft geen gebruik gemaakt van deze regeling vanwege een te grote administratieve belasting.

Wg: "Omdat dat een te grote administratieve belasting betekende. Er was nogal het een en ander aan rapportage vereist, er moest een begeleidingsplan komen en daar had ik helemaal geen zin in".

Eveneens een kwart van de respondenten is op de hoogte van ondersteuning in de vorm van job-coaching $(24 \%)$. Van de werkgevers die hiervan op de hoogte zijn, hebben er vier gebruik gemaakt van deze regeling. De andere werkgevers hebben hiervan geen gebruik gemaakt omdat deze vorm van ondersteuning niet nodig bleck te zijn.

Bijna de helft van de geïnterviewde werkgevers is op de hoogte van het bestaan van de loondispensatie regeling $(44 \%)$. Elf werkgevers die deze regeling kennen, hebben 
hiervan gebruik gemaakt. Een aantal werkgevers heeft geen gebruik gemaakt van deze regeling vanwege een te grote administratieve belasting bij de aanvraag ervan.

$\mathrm{Wg}$ : "Nou het is, mag ik eigenlijk niet zeggen, het is een hoop papieren rompslomp en je krijgt toch een beetje met instanties te maken die toch een beetje ambtelijk zijn, dus ja, je moet een hoop afdelingen en mensen doorlopen voor dat je eigenlijk de juiste gegevens krijgt en dat was wat vervelend. Ik heb zo'n beetje het idee dat ik van het kastje naar de muur werd gestuurd, eigenlijk voordat je eindelijk de juiste gegevens had."

Iets meer dan een kwart ( $29 \%$ ) van de geïnterviewde werkgevers is op de hoogte van de regeling loonvergoeding bij ziekte. Van de geïnterviewde werkgevers die op de hoogte zijn, heeft slechts een klein aantal gebruik gemaakt van deze regeling $(n=4$, $24 \%$ ). In de meerderheid van de gevallen wordt van deze regeling geen gebruik gemaakt omdat hiertoe (nog) geen reden bestaat, aldus de werkgevers.

Wg: "Nee, daarom ben ik zo stom geweest om het zelf te betalen. Maar wat is stom: die man is het voor mij op dat moment waard. Maar als hij ziek wordt kost het mij geld en daarover wist ik dus niets."

Tenslotte is de helft van hen $(47 \%)$ op de hoogte van het bestaan van een kostenvergoeding voor aanpassingen. De helft van diegenen bij wie deze regeling bekend is, heeft hiervan gebruik gemaakt, voornamelijk voor aanpassingen van meubilair en speciale computerapparatuur. De werkgevers die de regeling wel kennen maar er geen gebruik van hebben gemaakt, geven aan hier ook geen behoefte aan te hebben gehad.

Indien wordt gekeken naar de grootte van de bedrijven en de kennis omtrent de diverse wet- en regelgeving blijken name de bedrijven met minder dan twintig werknemers minder goed op de hoogte zijn van de bestaande wet- en regelgeving dan de bedrijven met meer dan twintig werknemers $\left(\mathrm{chi}^{2}=6.0, \mathrm{p}<0.05\right)$.

\section{Werkgeversperspectief: tijdsinvestering}

Bij de in hoofdstuk 2 beschreven vooroordelen ten aanzien van het aannemen van personen met een arbeidsongeschiktheidsverleden vanwege de aanwezigheid van een beperking, wordt geen melding gemaakt van een te verwachten grotere tijdsinvestering bij de aanname van personen met een dergelijke achtergrond. Desondanks kan een grotere tijdsinvestering belemmerend werken op het reìntegratieproces. Een klein deel 
van de geìnterviewde werkgevers $(11 \%)$ geeft aan dat de aannameprocedure meer tijd heeft gekost dan bij vergelijkbare andere werknemers. Redenen die hiervoor worden genoemd zijn het regelen van subsidies en het treffen van voorzieningen. De meningen van werkgevers omtrent de waarde van de grotere tijdsinvestering verschillen. Sommigen geven aan de grotere tijdsinvestering de moeite waard te vinden vanwege onder meer de toegekende subsidies of de prettige persoonlijkheid van de betreffende werknemer. Anderen vinden een grotere tijdsinvestering niet de moeite waard, bijvoorbeeld vanwege schending van de belangen van de andere werknemers.

Wg: "Nee, het was de investering in tijd niet waard, omdat ze echt beneden de maat is. Het heeft ons ook gewoon geld gekost, terwijl wij met dezelfde inspanningen ook geld hadden kunnen verdienen".

Er zijn geen werkgevers die aangeven dat de aannameprocedure minder tijd heeft gekost dan bij vergelijkbare werknemers zonder beperkingen.

\section{Werkgeversperspectief: betrokkenheid afdeling en informatievoorziening collega's}

In de situatie waarbij sprake is van een afdeling waar de gereìntegreerde werknemer te werk wordt gesteld, is vrijwel altijd deze afdeling betrokken bij de aanstelling (80\%). Deze betrokkenheid bestaat dan wel uit het deelnemen van het afdelingshoofd aan de selectie, c.q. de sollicitatieprocedure, dan wel uit een overleg tussen het afdelingshoofd en diegene die de werknemer aanneemt over de specifieke mogelijkheden van de sollicitant voor het bedrijf. Vaak vindt dit overleg voorafgaand aan de aanname plaats.

Wg: "De afdelingschef moest natuurlijk wel akkoord gaan om iemand aan te nemen zoals zij was. Maar hij zei ook heel nadrukkelijk van, joh, handicap of niet, als betrokkene kan functioneren in hetgeen wat ik vraag, dan heb ik daar geen problemen mee. En hij heeft haar uitstekend opgevangen".

Toekomstige collega's worden in de meerderheid van de gevallen $(n=53,71 \%$ ) geïnformeerd over de komst van de nieuwe werknemer, de beperkingen van deze werknemer en de consequenties ervan voor de werksituatie. Deze informaticvoorziening vindt voornamelijk mondeling plaats, maar wel op een formele wijze. Vaak informeert het afdelingshoofd de collega's, maar ook hogere leidinggevenden (dlg) nemen deze taak op zich. In enkele gevallen heeft de pas aangestelde werknemer 
zelf zijn/haar collega's geïnformeerd over aanwezige beperkingen en de consequenties daarvan voor de werksituatie.

Dlg: "In de kantine heb ik het verteld, dat er een nieuwe collega bijkwam. En dat hij via het reĩntegratiecentrum kwam. ledereen kent dat, het centrum geniet hier bekendheid. Vooral hier is dat goed bekend. Dus dat hoefde ik eigenlijk niet uit te leggen, dat wisten ze. Ik heb gezegd dat hij niet echt lichamelijk gehandicapt was. Dat hij geopereerd was en probeerde een herintrede te maken. En dat hij een beetje eigenaardig loopt en heel erg stil is. En dat ze hem daarmee niet moesten confronteren, gewoon als collega behandelen. Ze reageerden daar lacherig op. Ik zei dat hij een beetje met zijn been sleept en je weet hoe mensen daarop reageren. Je weet hoe dat gaat met jonge jongens, een keertje roepen, Is het hout? Ik zei, denk erom jongens, doe niet zo hard".

Wg: "Vervolgens hebben wij, personeelszaken en ik, de collega's ingelicht over de komst van hem. We hebben een compleet apart voorlichtingsprogramma gedraaid met video en richtlijnen. We hebben dus een breed informatiepakket aangeboden".

Dlg: "In eerste instantic zijn de medewerkers op de afdeling geĭnformeerd over de persoon die zou komen, over haar beperkingen en haar eventuele onvoorspelbare gedrag omdat zij moest wennen aan haar eigen beperkingen. Daar was zij zelf niet bij. Op die manier zijn de mensen geĭnformeerd, van luister eens, jullie moeten niet schrikken".

Ingeval de toekomstige collega's niet zijn geïnformeerd over de aard en consequenties van de beperking van de nieuw aangestelde werknemer, wordt hiervoor onder meer als reden gegeven dat daarmee de privacy van de persoon wordt geschonden, dan wel dat de beperking geen invloed heeft op de werksituatie en derhalve informatie hierover niet nodig is. In enkele gevallen geeft een werkgever aan dat informatievoorziening niet is gebeurd, omdat de collega's er zelf wel achter komen.

\section{Werknemersperspectief: Aanpassingen van de werksituatie in de eerste baan}

Mede vanwege de aanwezige beperkingen en aandoeningen (zie ook paragraaf 4.2) van de oud-cursisten kan er sprake zijn van belemmeringen in de uitoefening van een functie dan wel in het verrichten van werkzaamheden. Wanneer aanpassingen van de werksituatie kunnen worden aangebracht, vergroten deze de kans op blijvende succesvolle reìntegratie (Schultz-Johnson, 1987; Van Dijk et al., 1987; Philips, 1989; Ganz. 1990: Maas et al.. 1990; Michon \& Van Weeghel, 1990; Ter Huurne et al., 1990; Van Dooren, 1990; Mitchell, 1991: Diethelm \& Schüler, 1991: Bijl \& Lemmens, 1993; Nijboer et al.,1993; Johns et al.. 1994; Grijpink. 1994: Harlan \& Robert, 1998). Onder het aanpassen van functies worden hier voornamelijk aanpassingen verstaan op het gebied van taakinhoud, arbeidsomgeving, werktijden en werktempo. Echter. de 
cursisten volgen een scholingsprogramma voor een functie waarin de aanwezige beperkingen niet of nauwelijks meer een rol spelen (zie paragraaf 4.4 ). In die zin zullen aanpassingen van de werksituatie niet of slechts in beperkte mate noodzakelijk zijn. In het in dit proefschrift beschreven onderzoek is onderzocht in hoeverre aanpassingen noodzakelijk zijn vanuit de perceptie van de gereìntegreerde werknemer en vanuit de werkgever die hem/haar in dienst heeft genomen. In tabel 5.7 worden de door de gereïntegreerde werknemers genoemde aanpassingen op het gebied van meubilair, apparatuur, werkuren en ondersteuning door collega's weergegeven, die noodzakelijk blijken in de eerste baan na afronding van het scholingsprogramma.

Tabel 5.7 Aanpassingen en ondersteuning in de eerste baan na afronding van het scholingsprogramma $(n=357)$. Cursistenoordeel: aantallen en percentages.

\begin{tabular}{llllllllllllll}
\hline & $\begin{array}{l}\text { Totaal } \\
(\mathrm{n}-357)\end{array}$ & \multicolumn{4}{l}{$\begin{array}{l}\text { Hoensbroeck } \\
(\mathrm{n}=150)\end{array}$} & $\begin{array}{l}\text { Werkenrode } \\
(\mathrm{n}-44)\end{array}$ & $\begin{array}{l}\text { Sonneherdt } \\
(\mathrm{n}=52)\end{array}$ & $\begin{array}{l}\text { Heliomare } \\
(\mathrm{n}=66)\end{array}$ & $\begin{array}{l}\text { EEGA } \\
(\mathrm{n}=45)\end{array}$ \\
\hline Meubilair & 74 & $21 \%$ & 29 & $19 \%$ & 6 & $14 \%$ & 10 & $19 \%$ & 22 & $32 \%$ & 7 & $16 \%$ \\
Apparatuur $\cdots$ & 39 & $11 \%$ & 5 & $3 \%$ & 2 & $5 \%$ & 21 & $40 \%$ & 8 & $12 \%$ & 3 & $7 \%$ \\
Aanpassing werktijden $\cdots$ & 44 & $12 \%$ & 3 & $2 \%$ & 3 & $7 \%$ & 9 & $17 \%$ & 20 & $31 \%$ & 9 & $20 \%$ \\
Ondersteuning collega's $\cdots$ & 79 & $22 \%$ & 24 & $16 \%$ & 11 & $26 \%$ & 26 & $50 \%$ & 10 & $16 \%$ & 8 & $18 \%$ \\
\hline
\end{tabular}

$\cdots$ p $\leq 0.001$

Voor ongeveer een vijfde deel van de oud-cursisten blijken aanpassingen van het meubilair nodig (tabel 5.7). Dit aangepast meubilair wordt voornamelijk geregeld voor gereïntegreerde werknemers met rugklachten $\left(\mathrm{chi}^{2}=43.8, \mathrm{p}<0.001\right)$. Een gering aantal oud-cursisten geeft aan dat aangepaste apparatuur $(11 \%) \mathrm{en} / \mathrm{of}$ aangepaste werktijden $(12 \%)$ noodzakelijk zijn. Met name gereïntegreerde werknemers met een visusbeperking geven aan aangepaste apparatuur te hebben $\left(\mathrm{chi}^{2}=71.4, \mathrm{p}<0.001\right)$. Het aantal gereìntegreerde werknemers met aangepaste werktijden lijkt te worden bepaald door werknemers met visusbeperkingen of psychische problematiek. Ongeveer een vijfde van de respondenten geeft aan ondersteuning van collega's nodig te hebben. De werknemers met een visusbeperking overheersen in deze groep $\left(\mathrm{chi}^{2}=28.9, \mathrm{p}<0.01\right)$. In totaal geven 98 oud-cursisten aan dat een aanpassing nodig is, 49 oud-cursisten hebben twee aanpassingen nodig. 8 oud-cursisten noemen drie aanpassingen en 3 oudcursisten geven aan dat vier verschillende aanpassingen noodzakelijk zijn. In totaal zijn voor $44 \%$ van de oud-cursisten aanpassingen geregeld. In vergelijking met het onderzoek van Molenaar-Cox \& Prins (1998) blijken de oud-cursisten uit dit onderzoek in de eerste baan meer aanpassingen nodig te hebben $(44 \%$ ten opzichte van $14 \%$ ), hetgeen er op zou kunnen duiden dat bij de hier beschreven onderzoeksgroep sprake is van een meer complexe problematiek. 
Indien wordt gekeken naar mogelijke verschillen op reïntegratiecentrum niveau, blijken de oud-cursisten van Sonneheerdt relatief het meest aan te geven aanpassingen nodig te hebben $\left(\mathrm{chi}^{2}=17.5, \mathrm{p}<0.001\right)$. Zij maken met name relatief veel gebruik van aangepaste apparatuur $\left(\mathrm{chi}^{2}=57.4, \mathrm{p}<0.001\right)$ en ondersteuning van collega's $\left(\mathrm{chi}^{2}=\right.$ 36.2, $\mathrm{p}<0.001$ ). De oud-cursisten van Sonneheerdt hebben, gezien de aard van de beperking, i.c. een ernstige visuele handicap, relatief veel aangepaste apparatuur ter ondersteuning van de beroepsmatige werkzaamheden. Ondersteuning door collega's blijkt, gezien de aard van de beperking eveneens relatief vaak nodig. Een derde deel van de oud-cursisten van Heliomare maakt gebruik van aangepaste werktijden, hetgeen relatief veel is, met name in vergelijking met de oud-cursisten van Hoensbroeck waar vrijwel niemand gebruik maakt van aangepaste werktijden $\left(\mathrm{chi}^{2}=40.7, \mathrm{p}<0.001\right)$.

\subsubsection{Plaatsing op lange termijn}

Van het aantal oud-cursisten dat gemiddeld ongeveer tweeëneenhalve maand na het afronden van het reïntegratietraject een baan hebben gevonden, is ten tijde van onderhwige studie een gedeelte ng steeds werkzaam in de eerste haan. Daarentegen werkt het resterende gedeelte niet meer in deze baan. Een deel van de oud-cursisten heeft, zoals eerder gesteld, geen baan gevonden binnen twaalf maanden na afronding van het reïntegratietraject. Van deze personen én van degenen die hebben aangegeven niet meer in de eerste baan werkzaam te zijn, heeft een aantal personen wél een baan ten tijde van het onderzoek. Hiervan is een gedeelte afkomstig uit de groep die geen baan heeft gevonden binnen 12 maanden na afronding van het reïntegratietraject en een gedeelte komt uit de groep cursisten die niet meer werkzaam is in de eerste baan. Daarnaast resteren meerdere oud-cursisten die zowel op korte als op lange termijn geen baan hebben en enkele oud-cursisten die na de eerste baan geen werk meer hebben gevonden.

Het gemiddeld plaatsingspercentage is gestegen naar van $71 \%$ naar $75 \%$ (figuur 8 ). Van het aantal cursisten dat op korte termijn een baan heeft gevonden $(n=357)$, zijn op de lange termijn 184 personen nog steeds werkzaam in de eerste baan en zijn 128 personen werkzaam in een andere baan. Van de groep werkenden op korte termijn, hebben 45 oud-cursisten op de lange termijn geen baan. Van deze 45 personen zijn 41 personen na hun eerste baan nog in één tot twee banen werkzaam geweest. Van de groep personen die op korte termijn geen werk hebben $(n=147)$, zijn 66 personen op de lange termijn aan het werk. Uiteindelijk hebben $8 \mathrm{I}$ oud-cursisten zowel op de korte als op de lange termijn geen werk. Van deze groep blijken 13 personen na afronding van het scholingsprogramma te hebben gewerkt in gemiddeld één baan. 


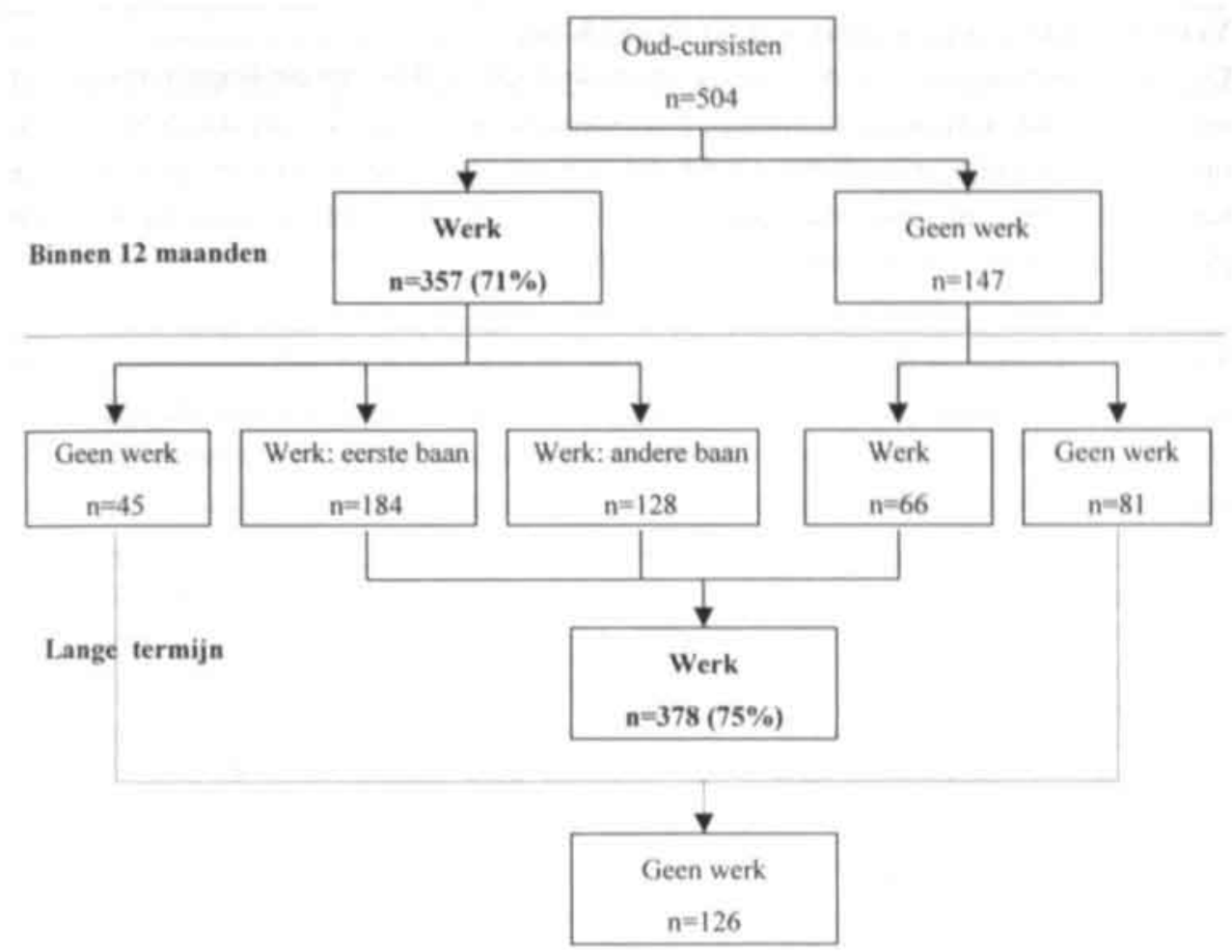

Figuur 5.1 Overzicht plaatsing op korte en lange termijn

Gezien deze resultaten lijkt het vinden van een baan binnen een redelijke termijn na het afronden van het reïntegratietraject conditioneel voor een blijvende arbeidsparticipatie.

In totaal hebben 378 oud-cursisten $(75 \%)$ op het meetmoment een baan. Van deze groep hebben 284 personen $(75 \%)$ een vast dienstverband. De overige $25 \%$ (94 personen) heeft een dienstverband voor bepaalde tijd. Een derde deel van de werkenden heeft nog een of andere uitkeringsvorm, die gemiddeld een derde deel van het totale inkomen beslaat (zie hiervoor paragraaf 5.4).

Het percentage oud-cursisten afkomstig van de centra Werkenrode, Hoensbroeck en Heliomare dat een baan heeft op de lange termijn, is gestegen. Het percentage oudcursisten afkomstig van de centra Sonneheerdt en EEGA dat op de lange termijn werkt, blijkt lichtelijk gedaald (zie hiervoor tabel 5.8). 


\section{Verdeling plaatsingsresultaten naar vakrichting}

De succespercentages van de diverse vakrichtingen blijken op de lange termijn niet veel van elkaar te verschillen (tabel 5.8). Daarnaast wijst toetsing uit dat de resultaten op de lange termijn vrijwel niet afwijkend zijn van de plaatsingspercentages op korte termijn. Het hogere plaatsingspercentage wordt in die zin niet veroorzaakt door een plaatsingstoename van een bepaalde vakrichting.

Tabel 5.8 Weergave van op lange termijn geplaatste oud-cursisten totaal en per reîntegratiecentrum, verdeeld over de vakrichtingen. Resultaat per vakrichting weergegeven als \% van het aantal afgestudeerden.

\begin{tabular}{|c|c|c|c|c|c|c|c|c|c|c|c|c|c|}
\hline \multirow[b]{3}{*}{ Administratic } & \multicolumn{3}{|l|}{$\begin{array}{l}\text { Totaal } \\
(n=504)\end{array}$} & \multicolumn{2}{|c|}{$\begin{array}{l}\text { Hoensbroeck } \\
(n=199)\end{array}$} & \multicolumn{2}{|c|}{$\begin{array}{l}\text { Werkenrode } \\
(\mathrm{n}=58)\end{array}$} & \multicolumn{2}{|c|}{$\begin{array}{l}\text { Sonneheerdt } \\
(n=77)\end{array}$} & \multicolumn{4}{|c|}{$\begin{array}{l}\text { Heliomare EEGA } \\
(n=97) \quad(n=73)\end{array}$} \\
\hline & richting & werh & & werk & & werk & & werl & & wer & & werk & \\
\hline & 219 & 157 & $72 \%$ & 56 & $81 \%$ & 20 & $83 \%$ & 18 & $52 \%$ & 49 & $80 \%$ & $14:$ & $50 \%$ \\
\hline Informatiebeheer & 66 & 49 & $74 \%$ & 15 & $79 \%$ & & & 10 & $77 \%$ & & & 24 & $73 \%$ \\
\hline Grafische technieken & 50 & 40 & $80 \%$ & & & 25 & $93 \%$ & 3 & $60 \%$ & 12 & $75 \%$ & & \\
\hline Elektrotechnick & 33 & 27 & $82 \%$ & 16 & $94 \%$ & & & 5 & $71 \%$ & 6 & $67 \%$ & & \\
\hline Fietstechniek & 6 & 4 & $67 \%$ & & & & & 4 & $67 \%$ & & & & \\
\hline Pianotechniek & 4 & 3 & $75 \%$ & & & & & 3 & $75 \%$ & & & & \\
\hline Meubelstofferen & 6 & 6 & $100 \%$ & & & & & 6 & $100 \%$ & & & & \\
\hline Tuinbouw & 5 & 4 & $80 \%$ & & & 4 & $80 \%$ & & & & & & \\
\hline Fijnmechanica & 17 & 12 & $71 \%$ & 12 & $71 \%$ & & & & & & & & \\
\hline Werktuigbouwk, tek. & 81 & 68 & $84 \%$ & 64 & $83 \%$ & & & & & 4 & $100 \%$ & & \\
\hline Diversen & 17 & 8 & $47 \%$ & & & & & 1 & $50 \%$ & 2 & $50 \%$ & 5. & $46 \%$ \\
\hline Totaal & 504 & 378 & $75 \%$ & 163 & $82 \%$ & 49 & $85 \%$ & 50 & $65 \%$ & 73 & $75 \%$ & $43:$ & $59 \%$ \\
\hline
\end{tabular}

De arbeidspositie van de oud-cursisten van Hoensbroeck is voor de vakrichting elektrotechnick opvallend verbeterd ten opzichte van de plaatsing op korte termijn. Voor de overige vakrichtingen worden bij de onderzochte reïntegratiecentra weinig opvallende verschillen gevonden.

\section{Werknemersperspectief: Aanpassingen van de werksituatie op de lange termijn}

Een deel van de populatic oud-cursisten heeft ook op de lange termijn aanpassingen nodig (tabel 5.9). Het percentage gereïntegreerde werknemers dat aangeeft op de lange termijn een aangepaste werksituatie te hebben is lichtelijk gedaald, echter niet significant. 
Tabel 5.9 Aanpassingen en ondersteuning in de baan op de lange termijn na afronding van het reintegratietraject ( $\mathrm{n}=378$ ). Aantallen en percentages, Meerdere antwoorden zijn mogelijk.

\begin{tabular}{llllllllllllll}
\hline & \multicolumn{2}{l}{$\begin{array}{l}\text { Totaal } \\
(\mathrm{n}=378)\end{array}$} & \multicolumn{3}{l}{$\begin{array}{l}\text { Hoensbroeck } \\
(\mathrm{n}=163)\end{array}$} & $\begin{array}{l}\text { Werkenrode } \\
(\mathrm{n}=49)\end{array}$ & $\begin{array}{l}\text { Sonneheerdt } \\
(\mathrm{n}=50)\end{array}$ & $\begin{array}{l}\text { Heliomare } \\
(\mathrm{n}=73)\end{array}$ & $\begin{array}{l}\text { EEGA } \\
(\mathrm{n}=43)\end{array}$ \\
\hline Meubilair $\cdots$ & 67 & $17 \%$ & 38 & $23 \%$ & 3 & $6 \%$ & 5 & $10 \%$ & 18 & $25 \%$ & 3 & $7 \%$ \\
Apparatuur $\cdots$ & 44 & $12 \%$ & 6 & $4 \%$ & 3 & $6 \%$ & 22 & $44 \%$ & 10 & $14 \%$ & 3 & $7 \%$ \\
Aanpassing werktijden $\cdots$ & 35 & $9 \%$ & 6 & $4 \%$ & 3 & $6 \%$ & 5 & $10 \%$ & 15 & $21 \%$ & 6 & $14 \%$ \\
Ondersteuning collega's $\cdots$ & 72 & $20 \%$ & 24 & $18 \%$ & 11 & $22 \%$ & 22 & $40 \%$ & 11 & $15 \%$ & 4 & $9 \%$ \\
\hline
\end{tabular}

$\cdots$ p $\leq 0.001$

In totaal geven 101 oud-cursisten aan een aanpassing nodig te hebben, 38 oudcursisten hebben twee aanpassingen nodig, 11 oud-cursisten noemen drie aanpassingen en 2 oud-cursisten geven aan dat vier verschillende aanpassingen noodzakelijk zijn. In totaal blijken na vijf jaar $40 \%$ van de oud-cursisten aanpassingen nodig te hebben.

De verschillen op centrumniveau zijn vergelijkbaar met de situatie op korte termijn. De gereīntegreerde werknemers die een scholingsprogramma bij Sonneheerdt hebben gevolgd, zijn verantwoordelijk voor de helft van het aantal gerapporteerde aanpassingen. Onderzocht is of er verschillen bestaan tussen het type aandoening en het benodigde aantal aanpassingen. Met name gereïntegreerde werknemers met neuromusculaire aandoeningen, visusbeperkingen. rugklachten en werknemers met zenuwbeschadigingen (plexus laesies) blijken meer dan anderen aanpassingen nodig te hebben $\left(\mathrm{chi}^{2}=33.4, \mathrm{p}<0.01\right)$.

Met behulp van Cohen's Kappa is onderzocht in hoeverre er overeenkomst bestaat tussen de gereïntegreerde werknemers die bij de eerste baan hebben aangegeven al dan niet aanpassingen nodig te hebben en dit al dan niet op de lange termijn hebben aangegeven. Bij deze berekeningen worden alleen die respondenten meegenomen, die op beide momenten werkzaam zijn en niet in dezelfde baan zijn gebleven. Er blijkt geen overeenkomst te bestaan tussen de respondenten die aangeven aanpassingen nodig te hebben in de eerste baan en degenen die aangeven aanpassingen in de huidige baan nodig te hebben $(\mathrm{Kappa}=0.20)$. Er zijn 21 gereìntegreerde werknemers die in eerste instantie geen aanpassingen nodig blijken te hebben en in de huidige baan wel. Daarentegen zijn er 24 werknemers die in eerste instantie wel aanpassingen nodig hebben en in de huidige baan niet. Een redelijke overeenkomst wordt gevonden bij de respondenten die aangeven aanpassingen van de werktijden te hebben geregeld (Kappa $=0.50)$. Voor de andere aanpassingen wordt geen tot een matige overeenkomst gevonden. 


\section{Werknemersperspectief: ervaren beperkingen in de werksituatie}

Wanneer aanpassingen zijn geregeld zou in principe er van uitgegaan kunnen worden dat een gereïntegreerde werknemer geen beperkingen meer ervaart in de werksituatie. Aan de oud-cursisten is gevraagd in hoeverre ze alsnog beperkingen ervaren in de werksituatie. Van de oud-cursisten die hebben aangegeven dat voor hen aanpassingen van de werksituatie zijn geregeld ( $n=153$ ), blijkt $39 \%$ beperkingen te ervaren in de werksituatie. Daarnaast blijkt $29 \%$ van de personen voor wie geen aanpassingen zijn geregeld, eveneens beperkingen in de werksituatie te ervaren. In tabel 5.10 wordt een overzicht gegeven van de ervaren beperkingen. Aangezien een aantal personen meerdere beperkingen aangeeft, kan het totaal percentage de $100 \%$ overschrijden.

Tabel 5.10 Ervaren beperkingen in de werksituatie $(n=378)$. Aantallen en percentages.

\begin{tabular}{|c|c|c|c|c|c|c|c|c|c|c|c|c|}
\hline \multirow[b]{2}{*}{ Beperkingen in werktempo } & \multicolumn{2}{|c|}{$\begin{array}{l}\text { Totaal } \\
(n=378)\end{array}$} & \multicolumn{2}{|c|}{$\begin{array}{l}\text { Hoensbroeck } \\
(n=163)\end{array}$} & \multicolumn{2}{|c|}{$\begin{array}{l}\text { Werkenrode } \\
(n=49)\end{array}$} & \multicolumn{2}{|c|}{$\begin{array}{l}\text { Sonneheerdt } \\
(\mathrm{n}=50)\end{array}$} & \multicolumn{2}{|c|}{$\begin{array}{l}\text { Heliomare } \\
(n=73)\end{array}$} & \multicolumn{2}{|c|}{$\begin{array}{l}\text { EEGA } \\
(n=43)\end{array}$} \\
\hline & 8 & $7 \%$ & 3 & $3 \%$ & & & 5 & $4 \%$ & & & & \\
\hline $\begin{array}{l}\text { Beperkingen in } \\
\text { stressbestendigheid }\end{array}$ & 5 & $4 \%$ & 4 & $3 \%$ & & & & & 1 & $1 \%$ & & \\
\hline Beperkingen in aantal werkuren & 12 & $10 \%$ & 4 & $3 \%$ & 1 & $1 \%$ & 1 & $1 \%$ & 4 & $3 \%$ & 2 & $2 \%$ \\
\hline Beperkingen in concentratie & 4 & $3 \%$ & 2 & $2 \%$ & & & 1 & $1 \%$ & & & 1 & $1 \%$ \\
\hline $\begin{array}{l}\text { Hulp nodig bij het uitvoeren van } \\
\text { werkzaamheden }\end{array}$ & 12 & $10 \%$ & 4 & $3 \%$ & & & 3 & $3 \%$ & 5 & $4 \%$ & & \\
\hline $\begin{array}{l}\text { Visuele beperkingen bij het } \\
\text { uitvoeren van werkzaamheden } \\
\text { Fysieke beperkingen bij het }\end{array}$ & 10 & $9 \%$ & 1 & $1 \%$ & 1 & $1 \%$ & 6 & $5 \%$ & 1 & $1 \%$ & 1 & $1 \%$ \\
\hline uitvoeren van werkzaamheden & 55 & $47 \%$ & 25 & $21 \%$ & 8 & $8 \%$ & 1 & $1 \%$ & 17 & $14 \%$ & 4 & $4 \%$ \\
\hline Beperkingen in de mobiliteit & 11 & $9 \%$ & 3 & $3 \%$ & 3 & $3 \%$ & 2 & $2 \%$ & 1 & $1 \%$ & 2 & $2 \%$ \\
\hline
\end{tabular}

Bij het uitvoeren van de werkzaamheden worden met name fysieke beperkingen ervaren (tabel 5.10). Indien de ervaren beperkingen worden gerelateerd aan de aandoeningen, blijken gereïntegreerde werknemers met chronische rugklachten, ondanks de gerealiseerde aanpassingen, toch nog fysieke beperkingen te ervaren bij het uitvoeren van de werkzaamheden. Deze werknemers zijn voornamelijk afkomstig van de reïntegratiecentra Hoensbroeck en Heliomare.

\section{Factoren inzake niet succesvolle arbeidsreïntegratie}

Zoals eerder aangegeven hebben 126 oud-cursisten ( $25 \%)$ geen baan binnen een jaar en/of op de lange termijn. De oud-cursisten die niet actief zijn op de arbeidsmarkt geven een diversiteit aan redenen op waarom ze op het moment van interview niet werken (zie tabel 5.11). 
In bijna de helft van de gevallen spelen gezondheidsproblemen een rol; sommige werknemers blijken (weer) volledig arbeidsongeschikt te zijn verklaard. Een aantal oud-cursisten vinden van zichzelf dat ze onaantrekkelijk zijn voor de arbeidsmarkt. Met name hebben zij de indruk dat ze te oud zijn, onvoldoende ervaring hebben en dat werkgevers van mening zijn dat ze minder kunnen dan anderen vanwege hun beperkingen.

Tabel 5.11 Redenen genoemd voor niet succesvolle arbeidsreintegratie $(n=126)$. Aantallen en percentages. Meerdere antwoorden zijn mogelijk

\begin{tabular}{lllllrrr}
\hline & $\begin{array}{l}\text { Totaal } \\
(\mathrm{n}=126)\end{array}$ & $\begin{array}{l}\text { Hoensbroeck } \\
(\mathrm{n}=36)\end{array}$ & $\begin{array}{l}\text { Werkenrode } \\
(\mathrm{n}=9)\end{array}$ & $\begin{array}{l}\text { Sonneheerdt } \\
(\mathrm{n}=27)\end{array}$ & $\begin{array}{l}\text { Heliomare EEGA } \\
(\mathrm{n}=24)\end{array}$ & \begin{tabular}{l}
$(\mathrm{n}=30)$ \\
\hline Gezondheidsproblemen
\end{tabular} \\
\hline & 53 & $42 \%$ & 15 & 5 & 11 & 12 & 10 \\
(nog) niet gelukte bemiddeling & 27 & $21 \%$ & 10 & 1 & 5 & 3 & 8 \\
Onaantrekkelijk voor markt & 49 & $39 \%$ & 19 & 3 & 11 & 5 & 10 \\
Niet (kunnen) voldoen aan eisen & 17 & $14 \%$ & 4 & 2 & 4 & 1 & 5 \\
Andere bezigheden & 10 & $8 \%$ & & 1 & 2 & 5 & 2 \\
Onvoldoende geschikte banen & 24 & $19 \%$ & 10 & & 6 & 3 & 5 \\
Tijdelijk werkloos, zoekende & 18 & $14 \%$ & 4 & 2 & 5 & 4 & 3 \\
Overige & 2 & $2 \%$ & 1 & & & & 1 \\
\hline
\end{tabular}

Oud-cursisten die aangeven dat een nog niet succesvolle bemiddeling de oorzaak is voor hun werkloze status, doelen op de bemiddeling door het reìntegratiecentrum of bemiddeling door arbeidsvoorziening of de uitkerende instantie. Wanneer oudcursisten aangeven dat er onvoldoende beschikbare banen zijn, betreffen dit veelal het tekort aan banen binnen hun eigen vakgebied, op hun niveau en/of binnen de voor hen bereikbare regio. Omgekeerd geven oud-cursisten aan niet te (kunnen) voldoen aan de eisen die door werkgevers worden gesteld.

Er worden geen verschillen gevonden tussen de reïntegratiecentra.

Samenvattend blijken vooral gezondheidsproblemen, de eigen perceptie en een onvoldoende groot arbeidsmarktaanbod redenen te zijn waarom oud-cursisten geen baan vinden. 


\section{Reflectie}

Indien de plaatsingsbevindingen in deze paragraaf worden vergeleken met de bevindingen in de literatuur, dan blijkt een sterke overeenkomst.

Een groot aantal personen geeft als reden voor de werkloze status een verminderde gezondheid aan. Bekend is dat personen met een verminderde gezondheid minder kans hebben op blijvende reïntegratie (Verkley, 1988; Van der Aa \& Vlaanderen, 1991; Van Beek \& Van Praag, 1992). Met name het geringere succes van personen met psychische problematiek is reeds in eerdere onderzoeken gevonden (Gogstadt, 1968; Cristol, 1970; Noble \& Collignon, 1987; Kaaij, 1992; Kers et al., 1996). Daarnaast ziet een aantal respondenten hun (reeds oudere) leeftijd als de oorzaak voor het niet vinden van een baan. Ook deze factor wordt erkend als zijn een factor die de kans op succesvolle reïntegratie verkleint (Gogstadt, 1968; Spruit et al., 1986; Bremer \& Corten, 1989; Van der Aa \& Vlaanderen, 1991; Van Beek \& Van Praag, 1992; Riipinen et al., 1994; Mannila, 1995; Straaton et al., 1996). Eveneens wordt het niet (kunnen) vinden van geschikte banen door de respondenten genoemd als bepalende factor, bevestigd door diverse auteurs (Mul et al., 1995; Ernste et al., 1995). Ten tijde van de onderzochte scholingsperiode is in Nederland sprake van een hoge werkloosheid en een matig banenaanbod (LISV, 2000). Het geringe baanaanbod op de toenmalige arbeidsmarkt kan een factor zijn die heeft meegespeeld bij het niet vinden van een baan. Tenslotte wordt in eerder onderzoek bevestigd dat werkgevers vooroordelen hebben ten aanzien van mensen met beperkingen (Bruggeman, 1991; Kenny, 1995; Van Elderen et al., 1995), echter of deze vooroordelen worden vertaald in een voor de oud-cursisten te hoog eisenpakket is niet duidelijk.

Op basis van deze bevindingen dient te worden onderzocht in hoeverre er een verschil bestaat tussen oud-cursisten die wel werk hebben gevonden en zij die geen werk hebben gevonden. De laatste groep is gemiddeld één jaar ouder dan de groep die wel werk heeft gevonden $(\mathrm{p}<0.01)$. Het is niet te veronderstellen dat dit geringe, significante leeftijdsverschil de verschillen in arbeidsstatus verklaart. Tevens is onderzocht in hoeverre de niet-baanvinders zich onderscheiden van de baanvinders als het gaat over de aard van de aandoening. Toetsing met behulp van een Kruskal-Wallistoets wijst uit dat oud-cursisten met psychische problematiek en oud-cursisten met visusbeperkingen relatief het minst aan het werk te zijn ( $\mathrm{chi}^{2}=24.3, \mathrm{p}<0.05$ ). De relatief hogere werkloze status van oud-cursisten met psychische problematiek is niet afwijkend van datgene wat in eerder onderzock is gevonden. De relatief hogere werkloze status van oud-cursisten met visusbeperkingen is (nog) niet eerder gevonden. 


\subsection{FUNCTIONEREN IN DE WERKSITUATIE: WERKGEVERSPERSPECTIEF}

In deze paragraaf worden de resultaten gepresenteerd van de interviews, gehouden met werkgevers die gereintegreerde werknemers in dienst hebben. In eerste instantie wordt een korte beschrijving gegeven van de benodigde aanpassingen en ondersteuning. Vervolgens wordt een beschrijving gegeven van het functioneren in de werksituatie van mensen met een arbeidsongeschiktheidsverleden.

\subsubsection{Aanpassingen en ondersteuning}

Nadat in paragraaf 5.2 een overzicht is gegeven van de door de gereìntegreerde werknemers aangegeven aanpassingen, wordt in deze paragraaf een overzicht gegeven van de aanpassingen die volgens de geïnterviewde leidinggevenden voor de gereïntegreerde werknemers zijn geregeld.

In totaal blijken volgens de geïnterviewde werkgevers, 48 gereïntegreerde werknemers behoefte te hebben aan een of meerdere aanpassingen (64\%). Dit impliceert dat voor de overige $36 \%$ geen speciale voorzieningen noodzakelijk zijn om normaal te kunnen functioneren in de werksituatie.

Dlg: "Nee, er zijn geen specifieke aanpassingen gemaakt buiten het normale arbobeleid. Ik moet zelfs eerlijk zeggen dat ik niet exact weet wat de handicap van hem is, omdat het in zijn functioneren niet is te merken".

Dlg: "Hij kan zijn armen niet gebruiken, hij kan niet lopen. Alleen met zijn tenen kan hij alles. Hij werkt met een muis en ook gewoon met een toetsenbord. In feite zit hij daar zo met zijn voeten, zijn toetsenbord staat een eind verderop en zijn scherm ook. En dan zit hij zo met zijn voeten, zit hij dat in te typen. Zijn handicap was geen enkel probleem, hij is ontzettend snel in feite met het omgaan van PC's".

Er bestaat slechts een matige overeenkomst tussen de gereïntegreerde werknemers die aangeven aanpassingen nodig te hebben en de door hun werkgevers aangegeven noodzakelijke aanpassingen (Kappa $=0,30$ ). Achttien gereïntegreerde werknemers zeggen geen aanpassingen nodig te hebben, terwijl deze volgens de werkgever wel nodig zijn. Omgekeerd zeggen tien werknemers wel aanpassingen nodig te hebben, hetgeen volgens hun werkgever niet het geval is.

Ongeveer de helft van de respondenten geeft aan dat de gereìntegreerde werknemer aanpassingen van de werkplek nodig heeft (tabel 5.12). Een derde van de leidinggevenden geeft aan dat bij de betreffende werknemer een aangepast takenpakket nodig is gebleken, en ongeveer $20 \%$ van hen geeft aan dat de bij hem/haar in dienst 
zijnde werknemer aangepaste werktijden heeft. Een derde van de gereïntegreerde werknemers heeft, volgens de geïnterviewde respondenten, ondersteuning nodig van collega's en/of leidinggevenden.

Tabel 5.12 Overzicht aanpassingen in de werksituatie $(n=75)$. Aantallen en percentages

\begin{tabular}{lll}
\hline Aanpassingen & Aantallen & percentages \\
\hline Aanpassingen van de werkplek/werksituatie & 36 & $48 \%$ \\
Aanpassingen van het takenpakket & 24 & $32 \%$ \\
Aanpassingen van de werktijden & 14 & $19 \%$ \\
Ondersteuning van collega's/leidinggevenden & 25 & $33 \%$ \\
\hline
\end{tabular}

\section{Aanpassingen van de werkplek}

Ongeveer de helft van de geïnterviewde werkgevers geeft aan dat voor de bij hen werkzame gereïntegreerde werknemer aanpassingen van de werkplek noodzakelijk zijn $(48 \%)$. De aanpassingen die noodzakelijk zijn, betreffen in de meeste gevallen aangepaste stoelen en/of aangepaste werkplekken $(n=21)$, dan wel speciale computerapparatuur $(\mathrm{n}=14)$. Sommige bedrijven hebben vanwege rolstoeltoegankelijkheid hun deuren en sanitair aangepast $(n=4)$. Voor driekwart $(71 \%)$ van de aangestelde werknemers is slechts één aanpassing gemaakt, bij sommigen meerdere aanpassingen.

Dlg: "Wij merkten dat zij last van haar rug had, dus hebben we een speciale stoel voor haar besteld. Maar dat doen we eigenlijk altijd voor degenen die veel zitwerk doen".

Dlg: "Omdat hij slechtziend is, heeft hij een groter beeldscherm nodig dan anderen. Met grotere lettertypen en hogere resoluties".

Wg: "Er staan allerlei piano's waar hij aan het stemmen is met handschoenen aan omdat het gevaar bestaat dat hij anders niet ziet of hij de toetsen etc. vuil maakt. Het is een extra voorziening voor hem".

Wg: "Op het moment dat ze binnenkomen, zijn ze niet meer gehandicapt. Natuurlijk, rolstoelen hebben we en daar moet je extra voorzieningen voor treffen. Maar vanaf het moment dat ze binnenkomen, moeten alleen voorzieningen worden getroffen waardoor ze zich niet meer gehandicapt kunnen en mogen voelen".

Vaak blijken deze aanpassingen van de werkplek door de pas aangestelde werknemer zelf te worden benoemd. Van de 36 leidinggevenden die aangeven dat aanpassingen op 
de werkplek noodzakelijk blijken te zijn, tekenen 17 leidinggevenden hierbij aan dat het verzorgen van aanpassingen bedrijfsbeleid is en er niet speciaal alleen voor de betreffende werknemer iets is geregeld. Dit kan de discrepantie tussen de antwoorden van de werkgever en de werknemer ten dele verklaren (zie paragraaf 5.2).

\section{Aanpassingen takenpakket}

Aanpassingen van het takenpakket blijkt bij ongeveer een derde $(n=24,32 \%)$ van de gereïntegreerde werknemers noodzakelijk volgens de geïnterviewde leidinggevenden. Met name wordt door hen de verminderde inzetbaarheid genoemd $(83 \%)$, de gereìntegreerde oud-cursist kan niet overal worden ingezet en heeft in sommige gevallen dus ook minder taken. Enkele leidinggevenden melden grotere veiligheidsmaatregelen, anderen de noodzakelijkheid van afwisselend werk.

Dig: "Het takenpakket is aangepast. Maar kijk, als zij gewoon zou kunnen zien, zou het gewoon een fantastische stoffeerster zijn. Dus, door haar toch grote handicap, maar wel haar wilskracht, kan ze het in grote lijnen toch uitvoeren, ik vind dat ontzettend knap. Ik zou voor haar wel nieuwe oogjes willen kopen".

Dlg: "Nou, in principe merk ik dat toch wel, het werk dat hij nu doet ja. Bijvoorbeeld, hij kan maar een arm gebruiken en ja, die andere jongens die daar op die afdeling zitten die zijn dus meer inzetbaar voor andere dingen".

Door het afdelingshoofd of de aangestelde werknemer zelf, wordt aangegeven dat aanpassing van het takenpakket noodzakelijk is. In de meeste gevallen betreft het een blijvend aangepast takenpakket. Dit aangepaste takenpakket van de betreffende werknemer heeft in een aantal gevallen een negatieve sfeer op de werkvloer omdat irritatie bij collega's ontstaat over het weglaten van vervelende taken voor de betreffende werknemer. Soms leidt een aangepast takenpakket ook tot een positieve sfeerverandering, bijvoorbeeld doordat afdelingen daardoor dichter bij elkaar komen.

\section{Aanpassingen werktijden}

Ongeveer $20 \%$ van de geïnterviewde leidinggevenden geeft aan dat de betreffende gereïntegreerde werknemer aangepaste werktijden heeft. In de meeste gevallen heeft de persoon zelf aangegeven dat deze aangepaste werktijden noodzakelijk zijn, een enkele keer is het een besluit van de leidinggevende. Deze aangepaste werktijden blijken meestal tijdelijk (blijvend: $\mathrm{n}=6,40 \%$ ). Aanpassingen van de werktijden houden onder meer in dat minder uren worden gewerkt, werknemers later beginnen of werknemers niet 's nachts of in het weekend hoeven te werken. 
Wg: "Hij werkt 28 uur per week, die eis heb ik gesteld. Veertig uur per week houdt hij niet vol. Hij is zo ernstig gehandicapt, hij is niet alleen blind, hij is ook doof en hij heeft ook epileptische aanvallen, dus dat valt allemaal niet mee. Hij moet dus dan minimaal 28 uur werken. Hij moet niet het idee hebben dat het een sociale werkplaats is. Het is een commercieel bedrijf en hij moet daar ook zijn steentje aan bijdragen".

Een enkel afdelingshoofd geeft aan dat aangepaste werktijden een negatieve invloed hebben op de werksfeer omdat collega's het niet eerlijk vinden dat de betreffende werknemer niet in het weekend hoeft te werken. Collega's raken hierdoor geïrriteerd.

\section{Overige aanpassingen}

Andere aanpassingen zijn incidenteel en specifiek voor de setting, zoals bijvoorbeeld een aparte kamer vanwege de aanwezigheid van een (blindegeleide) hond, een eigen parkeerplaats of kleine aangepaste materialen zoals handschoenen of een zwaardere liniaal. Daarnaast blijken niet alle plekken binnen het bedrijf waar de werknemer is aangesteld, even goed bereikbaar te zijn. Een kleine minderheid van de gereïntegreerde werknemers heeft problemen met de bereikbaarheid van voor hem/haar van belang zijnde plekken. Dit is onder meer het gevolg van problemen met traplopen en het niet zelf kunnen openen van deuren.

\section{Ondersteuning en begeleiding}

Volgens een derde deel van de geïnterviewde leidinggevenden $(33 \%)$ heeft de gereīntegreerde werknemer, in vergelijking met andere collega's, extra ondersteuning c.q. begeleiding nodig. Met name worden genoemd meer persoonlijke begeleiding bij het uitvoeren en aanleren van werkzaamheden $(\mathrm{n}=13)$, het overnemen van taken door collega's $(n=5)$, extra controle van de werkzaamheden $(n=4)$ of begeleiding bij verplaatsing vanwege de aanwezige visuele beperking $(\mathrm{n}=4)$. In een enkel geval is begeleiding op het sociale vlak noodzakelijk.

Dlg: "Nou, in een schoonmaakbedrijf moet je goede ogen hebben en die had hij niet. We hebben geen speciale aanpassingen gedaan, maar hij moet wel meer worden gecontroleerd dan ander personeel. Dat doen de jongens onder elkaar gewoon. Bijvoorbeeld omdat hij niet alles zelf even goed kan zien, onderschat hij dingen. Hij onderschat hoe hij moet schoonmaken, wat voor een soort zeep hij moet gebruiken. omdat hij het vuil zelf niet ziet. Daar wordt hij dan op gewezen door de andere jongens". 
Dlg: "Als zij een opdracht krijgt, waarvan je normaal bij iemand op middelbaar niveau zegt van "oké, dat moet zo en zo gebeuren", dan begrijpt ze je niet en moet je het vaak nog een keertje uitleggen. Als ze iets gaat doen, dan controleren we haar goed en leggen alles uit. Het is geen sociale instelling hier, en alle tijd die collega's aan haar besteden, gaat ten koste van hun eigen werk. Als mensen hun werk niet echt ongestoord kunnen doen van negen tot vijf, dan is dat erg vervelend. Dit heeft negatieve gevolgen voor haar en voor de afdeling".

Dlg: "Soms is ondersteuning nodig. De directe collega heeft natuurlijk te maken met de capaciteiten van iemand die zodra er een keer iets anders gaat, weer op het goede spoor moet worden gezet. Alle werkzaamheden spelen zich binnen hetzelfde straatje af. Zodra het een beetje afwijkt moet er worden bijgestuurd en dat gaat ten koste van de cigen tijd. Ik kan me heel goed voorstellen dat men op een gegeven moment denkt van nou, vandaag liever even niet. Het kost dus wel eens moeite".

Bij ondersteuning in de randvoorwaardelijke sfeer moet worden gedacht aan het regelen van vervoer, concrete begeleiding van collega's bij toiletbezoek en thee- en lunchpauzes. Met name door de randvoorwaardelijke ondersteuning, die voornamelijk door collega's wordt uitgevoerd, ontstaat soms een positieve verandering van de sfeer op de werkvloer. Dit omdat banden tussen collega's ontstaan, die mogelijkerwijs anders niet zouden worden gevormd. Bovendien wordt de betreffende werknemer hierdoor meer betrokken bij het afdelingsgebeuren.

In een enkel geval wordt aangegeven dat deze ondersteuning een extra belasting vormt voor de collega's.

\subsubsection{Algemeen en specifiek functioneren}

Aan de geînterviewde leidinggevenden is gevraagd naar het functioneren in de werksituatie van de gereïntegreerde werknemer die bij het bedrijf werkzaam is. Aangezien het vanwege de diversiteit aan functies en bedrijven, vrijwel onmogelijk is heldere criteria op te stellen ten aanzien van het functioneren van de gereïntegreerde werknemers, is gekozen voor de vergelijkende trap. Hierbij wordt een vergelijking gemaakt tussen het functioneren van de gereïntegreerde werknemer met dat van vergelijkbare collega's zonder beperkingen. De vragen hieromtrent zijn derhalve alleen gesteld aan de direct leidinggevenden van de betreffende gereïntegreerde werknemer omdat deze hierop beter zicht heeft dan hogere leidinggevenden. Sommigen geven aan dat een vergelijking met andere collega's niet mogelijk is (niet aanwezig).

In eerste instantie wordt een overzicht gegeven van de gemeten variabelen (zie tabel $5.13)$, vervolgens wordt meer specifiek op de afzonderlijke variabelen ingegaan. 
Tabel 5.13 Overzicht functioneren in de werksituatie: vergelijking gereīntegreerde werknemer met collega's zonder beperkingen. Aantallen en percentages

\begin{tabular}{lcccccccc}
\hline & Meer/hoger/beter & Vergelijkbaar & \multicolumn{2}{c}{ Minder/lager } & Nvt \\
\hline Algemene arbeidsproductiviteit $(\mathrm{n}=75)$ & 11 & $15 \%$ & 43 & $57 \%$ & 20 & $27 \%$ & 1 & $1 \%$ \\
Vakkennis $(\mathrm{n}=67)$ & 8 & $12 \%$ & 37 & $55 \%$ & 16 & $24 \%$ & 6 & $9 \%$ \\
Vaktechnische vaardigheden $(\mathrm{n}=67)$ & 12 & $18 \%$ & 38 & $57 \%$ & 14 & $21 \%$ & 3 & $4 \%$ \\
Sociale vaardigheden $(\mathrm{n}=67)$ & 7 & $10 \%$ & 47 & $70 \%$ & 11 & $16 \%$ & 2 & $3 \%$ \\
Werkhouding $(\mathrm{n}=67)$ & 18 & $27 \%$ & 41 & $61 \%$ & 7 & $10 \%$ & 1 & $1 \%$ \\
Verzuim $(\mathrm{n}=75)$ & 11 & $15 \%$ & 42 & $56 \%$ & 15 & $20 \%$ & 7 & $9 \%$ \\
\hline
\end{tabular}

\section{Algemene arbeidsproductiviteit}

Meer dan de helft van de geïnterviewde leidinggevenden geeft aan de arbeidsproductiviteit van de gereïntegreerde werknemer gelijk is aan die van collega's (57\%). Vervolgens vindt $15 \%$ de arbeidsproductiviteit van de gereïntegreerde werknemer hoger ten opzichte van collega's en een kwart van de geïnterviewden is van mening dat de arbeidsproductiviteit lager is (27\%).

Dig: "De mindere productiviteit komt maar gedeeltelijk door zijn visuele handicap, ook door zijn luiigheid. Als hij actiever zou zijn, zou hij veel meer voor elkaar kunnen krijgen, daar ben ik van overtuigd".

Dlg: "Zijn arbeidsproductiviteit is ietsje lager. Dat blijkt bijvoorbeeld uit het feit dat hij alles met een hand moet doen, minder snel bepaalde handelingen verricht, met name bijvoorbeeld dat intoetsen en dingen opruimen. Daar heeft hij gewoon wat meer tijd voor nodig".

Dlg: "Zijn arbeidsproductiviteit is hoger. Ik zou me kunnen voorstellen dat dat komt omdat hij meer heeft meegemaakt dan een gemiddelde medewerker en dat bij hem het bewustwordingsproces is ontstaan van, je zult ervoor moeten gaan! Ik denk dat de opleiding bij het reîntegratiecentrum hem dat ook duidelijk heeft gemaakt".

Een hogere arbeidsproductiviteit blijkt voornamelijk uit de inzet van de werknemer, de werkhouding en motivatie. Bovendien is het in enkele gevallen meetbaar in productieresultaten. Een lagere arbeidsproductiviteit blijkt onder meer uit een lager werktempo en een verminderde inzetbaarheid. In de helft van de gevallen speelt de beperking zelf hierbij geen rol. 


\section{Vakkennis}

Bij de helft van de gereïntegreerde werknemers is de vakkennis even groot als die van vergelijkbare collega's $(55 \%)$. Een klein deel $(12 \%)$ van de geînterviewden geeft aan dat de gereintegreerde werknemer beschikt over meer vakkennis, een kwart van de respondenten $(24 \%)$ is van mening dat de betreffende gereïntegreerde werknemer over minder vakkennis beschikt. De grotere vakkennis blijkt onder meer uit de kwaliteit van het geleverde werk en de ervaring van de leidinggevende geïnterviewde dat de betreffende werknemer in verhouding over meer kennis beschikt. Minder vakkennis blijkt onder meer uit de kwaliteit van het werk, uit het gegeven dat collega's het werk van de betreffende werknemer moeten corrigeren en/of door de mindere werkervaring van de gereïntegreerde werknemers. Ook komt het voor dat de gereīntegreerde werknemer meer tijd nodig heeft nieuwe kennis op te nemen.

Dlg: "De vakkennis die hij had vanuit het reīntegratiecentrum was wel meer op het gebied waarop hij zich had gespecialiseerd. Dat bleek uit het feit dat hij daar met computers omging die wij hier helemaal niet hebben. Hij had ook al cursussen gedaan op computergebied en wist dus daardoor soms wel meer".

Wg: "Waar we nu tegenaan lopen met hem in dit geval is het heel jammer dat hij heel weinig pedagogische ondersteuning heeft gehad en dat is eigenlijk het nadeel van deze man. Hij heeft de PTH gedaan en nu blijkt dat hij aan alle kanten tekort komt. Dat is een groot probleem en daar komt nog een stukje vakkennis bij, waar hij ook aan tekort komt. Dat is heel erg jammer, de opleiding zal wel heel duur zijn geweest. Het rammelt aan alle kanten, je verwacht toch wat meer inhoud op dit gebied".

DIg: "Hij heeft meer vakkennis over spreadsheets en tekstverwerking door zijn opleiding bij het reĩntegratiecentrum en dat zijn toch wel dingen die wij weer niet wisten".

\section{Vaktechnische vaardigheden}

Volgens meer dan de helft van de geînterviewde leidinggevenden (57\%) beschikt de betreffende gereïntegreerde werknemer over evenveel vaktechnische vaardigheden als vergelijkbare collega's. Een vijfde deel van de respondenten $(18 \%)$ geeft aan dat de gereïntegreerde werknemer over meer vaktechnische vaardigheden beschikt. Een ongeveer even groot aantal $(21 \%)$ is van mening dat de vaktechnische vaardigheden van de gereïntegreerde werknemer minder zijn dan die van vergelijkbare collega's. Meer vaktechnische vaardigheden blijken voornamelijk uit een hogere kwaliteit van het werk, een hogere inzet en meer kennis en inzicht dan vergelijkbare collega's. Minder vaktechnische vaardigheden blijken onder meer uit het lagere werktempo of minder kennis en inzicht dan vergelijkbare collega's. 


\section{Sociale vaardigheden}

Tweederde van de geïnterviewden ( $70 \%$ ) geeft aan dat de betreffende werknemer over evenveel sociale vaardigheden beschikt als vergelijkbare collega's. Een klein aantal geïnterviewden $(10 \%)$ geeft aan dat de gereïntegreerde werknemer beschikt over meer sociale vaardigheden, $16 \%$ van de respondenten is van mening dat de betreffende gereîntegreerde werknemer over minder sociale vaardigheden beschikt. Betere sociale vaardigheden uiten zich voornamelijk door goede communicatieve vaardigheden, een goed aanpassingsvermogen en enthousiasme. Minder sociale vaardigheden blijken onder meer uit de wijze waarop met collega's wordt omgegaan en een onvoldoende communicatie- en aanpassingsvermogen.

Wg: "Door het circuit waarin ze terecht zijn gekomen, van uitkeringen, van praten met allerlei mensen, hebben ze in verhouding met andere mensen wat eerder dat ze vinden dat ze ergens recht op hebben. Ze denken gauw dat ze worden benadeeld. Mensen die in dat circuit terecht zijn gekomen hebben het idee dat ze gepakt zullen worden en dat is op een gegeven moment helemaal niet waar. Je werkt gewoon bij een bedrijf, daar word je gewaardeerd. Ze hebben ook een soort angst en daardoor gaan ze zich vaak indekken terwijl dat helemaal niet nodig is. En als er een keer kritiek is, daar wordt soms wat moeilijker mee omgegaan".

Wg: "Als mensen met cen beperking hier nieuw binnenkomen, krijgen ze een redelijk krediet bij collega's. Maar als zij zich op een zodanige wijze manifesteren dat ze zich constant achter die handicap verschuilen en veel aandacht vragen voor die handicap, terwijl die handicap heel duidelijk zichtbaar is en men er dus gewoon wel bewust van is dat er een handicap is, dau begint dat irritaties op te roepen en dan komt van het een het ander. En op een gegeven moment gaat alles irriteren. Maar dat ligt niet aan haar handicap, ik denk dat dat in haar persoonlijkheid ligt".

Dlg: "Zijn sociale vaardigheden zijn duidelijk beter, dat blijk wel uit zijn gedrag. meegaandheid en zijn opstelling ten opzichte van collega's".

Dlg: "Haar sociale vaardigheden zijn wat minder. Ze kan niet altijd even goed inschatten hoe haar gedrag bij anderen overkomt ze is namelijk nogal een dwingeland, aanhoudend gezeur ergens over soms. Ze heeft ook nogal een negatieve instelling, misschien wel door wat ze allemaal heeft meegemaakt, zo van dit lukt niet en dat lukt niet. Verdedigend, afwerend. Ik probeer haar zoveel mogelijk te wijzen op haar verantwoordelijkheden en haar zo zelfstandig mogelijk laten proberen te werken".

\section{Werkhouding}

Volgens ruim de helft van de geïnterviewden heeft de betreffende gereïntegreerde werknemer een vergelijkbare werkhouding als die van zijn/haar collega's $(61 \%)$. Ruim 
een kwart van de geìnterviewden $(27 \%)$ geeft aan dat de werkhouding van de gereïntegreerde werknemer beter is dan die van vergelijkbare collega's en $10 \%$ van de respondenten vindt de werkhouding van de gereïntegreerde werknemer minder goed dan die van vergelijkbare collega's. Een betere werkhouding is grotendeels herkenbaar door de inzet, motivatie en concentratie van deze werknemers. Bovendien kan daarbij sprake zijn van een hogere arbeidsproductiviteit. Een minder goede werkhouding blijkt voornamelijk uit een onvoldoende verantwoordelijkheidsbesef.

Dlg: "Zijn werkhouding is beter, hij is wat vasthoudender. Hij is gewoon erg gedreven en hij wil bewijzen dat hij het kan".

Dlg: "Hij wil zich wel eens drukken. Hij heeft wel eens de neiging om iemand op te gaan zoeken en daar dan een uurtje te gaan praten. Zeker met warm weer wil hij zich wel eens drukken".

Dlg: "Haar werkhouding is vele malen slechter en dat komt mede door haar handicap. Zij heeft altijd pijn en dat uit zich in vermoeidheid. Ze komt hier weleens binnen dat ze al te moe is om te beginnen. Dat roept ook de nodige spanningen op bij collega's".

\section{Verzuim}

Het verzuimgedrag van de gereïntegreerde werknemer is vergelijkbaar met dat van vergelijkbare collega's, aldus de mening van de helft van de geĭnterviewde leidinggevenden $(56 \%)$. Een vijfde deel van de respondenten $(20 \%)$ zegt dat de gereïntegreerde werknemer een lager verzuim heeft dan vergelijkbare collega's, $15 \%$ van de respondenten geeft aan dat het verzuimgedrag hoger is.

Wg: "Gelijk. Een keer heeft hij wel problemen gehad, omdat hij toen een nieuwe prothese moest hebben. Hij is toen op dieet geweest, met de gevolgen dat er meer speling op zijn prothese kwam en dat irriteerde mateloos. Hij is toen ongeveer vijf weken thuis geweest. Hij was dus niet echt ziek, maar omdat hij lijnde paste zijn prothese niet meer.

Wg: "Ziekte heeft eigenlijk ook nooit zorgen gegeven, ze is bijna nooit ziek. Nee, een lekke band voor haar rolstoel is eigenlijk alles, voor de rest scharrelt ze altijd vrolijk langs."

Dlg: "lets hoger. Hij pakt makkelijk de telefoon van ik voel me niet goed, ik blijf thuis".

Wg: "Haar verzuim is lager in vergelijking met collega's, ze verzuimt nooit. Ook vakanties neemt ze niet op. Ik moet haar dwingen om op vakantie te gaan. Nou goed, een weekje dan. I k vind dan dat er nog een week bij moet. Nou dat doet ze dan en dan gaat ze in die week bij die andere werkgever werken". 
Redenen waarom méér wordt verzuimd zijn onder meer omdat volgens de werkgevers de gereīntegreerde werknemers eerder last van hebben van klachten die gerelateerd zijn aan de beperking(en) of dat noodzakelijke operaties moet worden uitgevoerd.

\section{Invloed werksfeer}

De helft van de geïnterviewden (53\%) geeft aan dat de aanstelling van de gereïntegreerde werknemer geen invloed heeft gehad op de sfeer op de werkvloer. Vrijwel alle overige geïnterviewde leidinggevenden (39\%) zijn van mening dat de aanstelling van de betreffende werknemer met al dan niet zichtbare beperkingen een positieve invloed heeft gehad op de sfeer op de werkvloer. Deze positieve verandering blijkt uit onder meer een betere werksfeer, meer begrip en respect voor elkaar en met name voor de gereïntegreerde werknemer, aldus de geïnterviewde leidinggevenden. Als redenen voor deze positief veranderde sfeer worden voornamelijk gegeven de uitstraling van de betreffende werknemer, de goede inzet, goede sociale vaardigheden, lager verzuimgedrag, goede collegialiteit en een hogere arbeidsproductiviteit.

Dig: "Wat ik heb gemerkt, is dat het met haar collega's niet zo goed ging in het begin. Er werden opmerkingen over haar handicap geplaatst door haar collega's. Ze zit in een ploeg met veel mannen en dit leidde tot vervelende situaties. Deze collega's is heel goed duidelijk gemaakt dat ze dit niet accepteerde. Ze is nu volledig geaccepteerd in de groep".

Dlg: "De sfeer op de afdeling is beînvloed. Met name in het begin is iedereen nieuwsgierig. De hond van haar heeft ook een bepaalde sfeer, die is zelfs als officieel medewerker in dienst getreden. Mensen gaan toch iets anders met elkaar om, omdat ze van dichtbij iemand met een handicap zien. Ze zien wat dat voor problemen op het persoonlijk gebied kan hebben, maar ook hoe iemand daar iedere dag bovenuit kan stijgen. Dus heel duidelijk heeft het wel zijn invloed".

Enkele geìnterviewden ( $5 \%$ ) geven aan dat de sfeer minder is geworden sinds de aanstelling van de betreffende werknemer. Dit is onder meer herkenbaar door de weerstand van collega's ten opzichte van de gereîntegreerde werknemer, dan wel uit kleine irritaties bij collega's.

Dlg: "Als hij zich op een irritante wijze manifesteert bij de collega's, dan hebben zij een veel groter machtsmiddel om het hem te laten voelen dan normaal onder collega's gebeurt. lemand die rolstoelgebonden is kun je gemakkelijk weren van je afdeling. Zet maar een zware kast op een plak waar hij er niet langs kan, dat soort sferen kun je hier wel vinden". 
Redenen die worden genoemd voor de verminderde werksfeer hebben betrekking op de 'excuusfunctie' van de beperking.

Dlg: "Haar directe collega's, die moeten koffie halen. $\mathrm{Zij}$ hebben al heel gauw de neiging om alles voor haar te doen en zij heeft de neiging daar misbruik van te maken. Zij zal anderen gebruiken om dingen voor haar te doen, en het zijn allemaal dingen die ze zelf kan doen. Dit heeft met haar persoonlijkheid te maken, niet met haar handicap."

Met name blijken aanpassingen van het takenpakket en de benodigde ondersteuning van invloed te zijn op de sfeer op de werkvloer. Aanpassingen van de werkplek en aangepaste werktijden blijken geen invloed te hebben op de sfeer op de werkvloer.

\section{Doorgroeimogelijkheden}

Bij vrijwel alle bedrijven ( $88 \%$ ) geldt dat doorgroeimogelijkheden aanwezig zijn voor de werknemers. De doorgroeikansen van de gereïntegreerde werknemers blijken in meer dan de helft van de gevallen ( $58 \%)$ gelijk aan die van collega's in vergelijkbare functies. Een klein aantal geïnterviewde leidinggevenden $(15 \%)$ geeft aan dat de doorgroeimogelijkheden kleiner zijn, een enkele geìnterviewde $(5 \%)$ schat in dat de kans op doorgroei groter is, in vergelijking met die van collega's.

$\mathrm{Wg}$ : "Groter, door zijn positieve instelling en prettige manier van omgaan met collega's. Daarnaast kan hij als oud-onderwijzer goed kennis overdragen".

Wg: "Hij verdient minimumloon en als ik het commereieel ga bekijken, dan is het onverantwoord om hem dat loon uit te betalen en praat ik nog niet over hem opslag te geven. Want hij kan dus een heleboel dus perse nooit, hij doet er veel langer over dan iemand anders".

Dlg: "Hij is te werk gesteld als machinebediende. Eerst heeft hij een tijdje meegelopen als een soort stage. Toen bleek het dat hij heel wat pit had, hij was goed wakker. Daardoor kon hij vrij snel zelfstandig met de machines werken en is hij meewerkend voorman geworden".

Wg: "Hier heeft ze ook al op veel plaatsen gesolliciteerd, maar ze is er nooit in geslaagd om op een plek te komen, die ze ambieerde. Ze heeft eigenlijk weinig inzicht in haar handicap. Zij denkt zelf dat ze tot meer in staat is als wat anderen ervaren. Bepaalde werkzaamheden kan ze nu eenmaal niet uitvoeren. Ze maakt af en toe fouten met het opbergen van dingen bijvoorbeeld en dat keen zich tegen haar. Ik zeg ook wel eens van. luister je mag blij zijn dat je hier werkt en ook op de plek waar je kan werken, maar ze wil graag meer". 
Van de geïnterviewde leidinggevenden die hebben aangegeven dat de kans op doorgroei voor de gereïntegreerde werknemer kleiner is, geven vijf respondenten aan dat de aanwezige beperking hiervoor de reden is. Andere redenen die worden gegeven zijn onder meer het tijdelijke dienstverband, het huidige functioneren, te weinig capaciteiten of omdat de functie geen kans biedt op promotie. Meer kans op promotie is het gevolg van de aanwezige vaardigheden en/of de positieve instelling van de gereìntegreerde werknemer, aldus de geïnterviewde leidinggevenden.

$\mathrm{Bij}$ de helft van de bedrijven waarbij doorgroeimogelijkheden aanwezig zijn, heeft de gereïntegreerde werknemer reeds een doorgroei meegemaakt. Meestal in de zin van promotie, extra opslag en/of het dragen van meer verantwoordelijkheid.

\subsubsection{Werkgeversperspectief: factoren van invloed op blijvende integratie}

In hoofdstuk 2 worden meerdere factoren genoemd die van invloed zijn op reïntegratie. Het volgen van een scholingsprogramma wordt gezien als een factor die de reïntegratiekans positief beïnvloedt. De in dit proefschrift beschreven werknemerspopulatie heeft als gemeenschappelijk kenmerk dat zij een scholingsprogramma hebben doorlopen en ten dele succesvol zijn gereïntegreerd. Het grootste deel van de gereintegreerde werknemers is uitgestroomd uit de WAO. Het streven is echter tevens hernieuwde instroom te voorkomen. Aan de geìnterviewde leidinggevenden is gevraagd welke factoren naar hun idee van invloed zijn op blijvende succesvolle reïntegratie van mensen met beperkingen.

De geìnterviewde leidinggevenden maken in hun antwoord op deze vraag een onderscheid tussen factoren die bijdragen aan succesvolle integratie en factoren die de integratie kunnen laten mislukken (tabel 5.14). In een aantal gevallen zijn deze factoren complementair (meerdere antwoorden zijn mogelijk).

Tabel 5.14 Overzicht factoren van invloed op succesvolle blijvende integratie van mensen met beperkingen. $(n=75)$. Aantallen

\begin{tabular}{llcc}
\hline & & $\begin{array}{c}\text { positieve } \\
\text { bijdrage }\end{array}$ & $\begin{array}{c}\text { negatieve } \\
\text { bijdrage }\end{array}$ \\
\hline $\begin{array}{l}\text { Persoonsgebonden } \\
\text { factoren }\end{array}$ & Inzet en motivatie van werknemer & 25 & 7 \\
& Sociale vaardigheden werknemer & 7 & 5 \\
& Vakbekwaamheid werknemer & 6 & 4 \\
& Flexibiliteit werknemer & \multicolumn{2}{c}{3} \\
\hline
\end{tabular}


Tabel 5.14 Overzicht factoren van invloed op succesvolle blijvende integratie van mensen met beperkingen. $(\mathrm{n}=75)$. Aantallen

\begin{tabular}{llcc}
\hline $\begin{array}{l}\text { Bedrijfsgebonden } \\
\text { factoren }\end{array}$ & Voorbereiding van plaatsing door bedrijf & 16 & 8 \\
\cline { 2 - 3 } & Attitude collega's & 13 & 5 \\
& Afstemming werk en capaciteiten en mogelijkheden werknemer & 3 & 11 \\
& Aangepaste werkplek/werkomgeving & 10 & 3 \\
& Flexibiliteit vanuit de organisatic & 10 & 1 \\
& Attitude werkgever & 8 & 1 \\
Begeleidingsmogelijkheden voor werknemer & & 8 \\
Positie van werknemer & 3 & 3 \\
\hline Inpasbaarheid binnen team & 6 & 8 \\
factoren & Faciliterende wet- en regelgeving & 1 & 4 \\
\hline
\end{tabular}

Factoren die worden genoemd kunnen worden onderscheiden in persoonsgebonden factoren, bedrijfsgebonden factoren en omgevingsgebonden factoren. Met betrekking tot persoonsgebonden factoren blijken met name inzet, motivatie, sociale vaardigheden en vakbekwaamheid van de persoon doorslaggevend te zijn voor succes, aldus de geïnterviewde leidinggevenden.

Wg: "In de eerste plaats denk ik dat dat heel sterk samenhangt met de persoon, dat is dus psychologisch. Op het moment dat iemand echt wil, als blijkt dat je daar sympathie voor hebt, stappen mensen makkelijker over belemmeringen heen dan wanneer dat niet zo is. Dan wordt men tegendraads, dan vindt men altijd wel iets van dingen die dan normaal geen probleem zijn, die dan ineens wel een probleem worden. Relationele verhoudingen zijn heel belangrijk, hoe gaat iemand met zijn handicap om, hoc presenteert hij zich? Is hij opgeruimd in de zin van, is hij pessimistisch, straalt hij een stukje luiheid uit? Dat is toch heel belangrijk. Die factoren verschillen in wezen niet van iemand zonder een handicap, maar ze worden toegeschreven aan zo'n handicap. Het gaat toch om een stuk beeldvorming wat er omheen plaatsvindt. Die factoren worden sterker, daar wordt een soort hogere waarde aan toegekend". 
Bedrijfsgebonden factoren die langdurige reïntegratie bevorderen, hebben voornamelijk betrekking op een goede voorbereiding van de plaatsing door het bedrijf, bijvoorbeeld door middel van voorlichting aan toekomstige collega's, de houding van het management en het personeel ten opzichte van het in dienst hebben van personen met een beperking alsmede een goede afstemming van de werkplek op de persoon met zijn/haar beperkingen.

Wg: "Een reĩntegratie mislukt wanneer een bedrijf iemand met een handicap op de verkeerde plek zet. Je kunt natuurlijk nooit van tevoren inschatten met iemand die je zonder handicap aanneemt, of dat allemaal goed gaat. Maar ik denk dat je bij het plaatsen van mensen met een handicap vooraf tien keer zo goed moet nadenken of het de juiste werkplek is voor iemand".

$\mathrm{Wg}$ : "In het begin zou er aandacht moeten worden besteed aan het draagvlak van de rest van het personeel om iemand aan te nemen met een handicap. Als je dat hebt is de aanname en de begeleiding daar een uitwerking van. Het mislukt als je niet goed overlegt met collęga's want ik denk dat dat scht noodzakeljik is dav ser sen goeste informatievoorziening is en het tijdig bij betrekken van personeel etc.".

Wg: "Maar dat hij blind is, daar heeft het hele bedrijf last van. Om een voorbeeld te geven, hij loopt hier het gebouw uit met zijn hond en denkt naar beneden toe te lopen, loopt hij hier zo een kamer binnen, twee kamers binnen, waar net een vergadering bezig is. Het is wel lachen, maar iedereen heeft daar dus last van en in dit soort situaties moet dat dus heel breed gedragen worden.".

Als omgevingsgebonden factoren die de reïntegratiemogelijkheden bevorderen, wordt door de respondenten voornamelijk de begeleiding door externe instellingen bij het aanstellen en bij het in dienst hebben van de gereïntegreerde werknemer genoemd. Een goede begeleiding van buitenaf heeft een positieve invloed op een succesvolle blijvende integratic.

Wg: "Als ik even kijk met de ogen van een ondernemer. Ik denk dat het heel goed is, zeker bij cen blind persoon dat daar een soort 'job-coach' tijdelijk bij zou zijn en dat ja als onderneming voorlopig even niet lastig wordt gevallen met 'regelingetje zus, regelingetje $20^{\circ}$, En is dat prima voor elkaar en die werknemer kost een aantal maanden niets, maar maakt het vervolgens waar. Dan denk ik dat er heel veel ondernemers zijn, die zeggen van ja. Maar als je in het begin teveel zit te pushen van, neem me nou in dienst, dan denk ik dat mensen zeggen, dan heb ik weer zoveel rompslomp. Je moet eigenlijk die hele rompslomp weghalen. En het zoveel mogelijk in een situatie kanaliseren. Bijvoorbeeld door zo'n jobcoach, die weet alles en die regelt alles". 
Tot slot wordt nog opgemerkt dat naar het idee van de leidinggevenden een reìntegratie kans maakt te mislukken wanneer de, bij de betreffende werknemer, aanwezige capaciteiten en mogelijkheden in de praktijk minder blijken te zijn dan in eerste instantie wordt aangegeven. Ook wordt aangegeven dat een te groot aantal aanpassingen de kans op reïntegratie negatief beìnvloedt, tenzij een tegemoetkoming in de kosten mogelijk is.

\subsection{KOSTEN VERSUS BATEN}

Het primaire doel van de reìntegratiecentra is het toeleiden van personen met een arbeidshandicap naar betaald werk. Daardoor ontstaat vervolgens een verminderd beroep op de sociale zekerheid voor diegenen die een scholingsprogramma hebben gevolgd en gereïntegreerd zijn. Het hebben van betaald werk en een verminderd beroep op de sociale zekerheid kan daarom worden gezien als een van de baten van het volgen van een scholingsprogramma. Overige baten betreffen het verwerven van een nieuwe status en positie, deze zijn echter moeilijk in financiële termen uit te drukken. In de in dit proefschrift beschreven studie is onderzocht in hoeverre oud-cursisten betaald werk hebben en in hoeverre zij (nog) gebruik maken van een uitkering. De kosten die gepaard gaan met het scholen van de cursisten zijn eveneens in kaart gebracht. Voor wat betreft de kosten van de scholingsprogramma's is uitgegaan van het dagtarief. Dit dagtarief is opgebouwd uit alle variabele en vaste kosten van het scholingsprogramma. Verondersteld mag worden dat dit een reële afspiegeling is van de daadwerkelijke kosten, i.c. de kostprijs.

Inzicht in de scholingskosten en inzicht in de inkomens- en uitkeringspositie biedt de mogelijkheid om de kosten van de scholingsprogramma's af te zetten tegen de baten van de scholingsprogramma's, in dit geval uitgedrukt als een verminderd gebruik van uitkeringen tengevolge van het hebben van betaald werk.

De totale vaste en variabele kosten van een scholingsprogramma tijdens de onderzochte periode bedragen, uitgaande van het aantal scholingsdagen vermenigvuldigd met het dagtarief, gemiddeld $f$ 105.298,- per cursist.

Aan de baten-kant wordt uitgegaan van het perspectief van de sociale zekerheid. Cursisten die een baan vinden, verwerven daarmee een inkomen en maken geen of slechts nog een geringe aanspraak op een sociale uitkering. In tabel 5.15 wordt een overzicht gegeven van de uitkeringspositie van oud-cursisten, waarbij een onderscheid wordt gemaakt tussen oud-cursisten die werken en oud-cursisten die niet werken. 
Tabel 5.15 Overzicht uitkeringspositic oud-cursisten, werkenden en niet-werkenden ( $\mathrm{n}-504)$. Aantallen en percentages

\begin{tabular}{|c|c|c|c|c|c|c|}
\hline \multirow[b]{2}{*}{ Geen uitkering } & \multicolumn{2}{|c|}{$\begin{array}{l}\text { Gehele populatie } \\
n=504\end{array}$} & \multicolumn{2}{|c|}{$\begin{array}{l}\text { Werkenden } \\
n=378\end{array}$} & \multicolumn{2}{|c|}{$\begin{array}{l}\text { Niet-werkenden } \\
n=126\end{array}$} \\
\hline & 259 & $51 \%$ & 251 & $66 \%$ & 8 & $6 \%$ \\
\hline Wel uitkering & 245 & $49 \%$ & 127 & $34 \%$ & 118 & $94 \%$ \\
\hline
\end{tabular}

De helft van de gehele populatie oud-cursisten heeft een of andere vorm van uitkering, variërend van een WAO-uitkering, WW-uitkering of $\mathrm{BW}$-uitkering of een combinatie van deze uitkeringen. Het gemiddelde uitkeringspercentage voor de oud-cursisten die werken, bedraagt $32 \%$.

\section{Modelmatige doorberekening van de kosten-baten analyse}

Voor het bepalen van de kosten en baten van de scholingsprogramma's kunnen twee scenario's worden gehanteerd. Ten eerste het scenario dat uitgaat van de ideale situatie, namelijk een rendement van $100 \%$. Het tweede scenario gaat uit van de reële situatie.

\section{Scenario 1: Maximaal rendement}

Uitgaand van een cohort van 50 cursisten zou een maximaal rendement betekenen dat:

- alle oud-cursisten binnen enkele maanden een baan hebben.

- geen van de oud-cursisten nog aanspraak maakt op een uitkering,

- oud-cursisten, indien zij een baan gevonden hebben, ook werkzaam blijven (in dezelfde of in een andere baan),

- de gemiddelde uitkeringskosten gelijk zijn aan de landelijk gemiddelde AAW/WAO uitkeringskosten voor werknemers en vroeggehandicapten (uitsluitend $\mathrm{AAW}$ ), die in de cursistenpopulatie verdeeld zijn in de verhouding 2:1. Dit kan, rekening houdend met het jaar van uitstroom, worden geschat op $f$ 25.700,- per persoon per jaar (CTSV, 1997).

Kosten van de het scholingsprogramma:

Per 50 cursisten bedragen de integrale kosten van het scholingsprogramma (alle variabele en vaste kosten zijn hierin opgenomen): $f 5.264 .900,-$. Dit impliceert dat de kostprijs per student $f 105.298$,- bedraagt.

Opbrengsten:

Uitgaande van een cohort van 50 cursisten levert dit maximaal een besparing op per jaar van $50 \times f 25.700$.- (gemiddeld uitkeringsniveau) van $f 1.285 .000,-$. Bij een maximaal rendement worden de scholingskosten in 4.1 jaar terugverdiend. 


\section{Scenario 2: Het werkelijk gerealiseerde rendement}

Uitgaande van een cohort van 50 cursisten betekent het werkelijk gerealiseerd rendement:

- van de cursisten heeft gemiddeld $50 \%$ werk, zonder enige vorm van uitkering (25 uitkeringsjaren),

- $\quad 25 \%$ heeft werk met gemiddeld $32 \%$ uitkering ( 8.5 uitkeringsjaren),

- $25 \%$ heeft ondanks het reïntegratieprogramma geen werk en blijft aanspraak maken op een uitkering.

Bij 50 cursisten worden, uitgaande van de resultaten, over de onderzoeksperiode jaarlijks 33.5 uitkeringsjaren bespaard. Onder de terechte aanname dat iedereen die werk krijgt, ook aan het werk (zelfde of andere baan) blijft, levert het scholingsprogramma jaarlijks $f 860.950,-$ op.

Uitgaande van dezelfde scholingskosten als in scenario 1 geldt dat bij de gemiddelde financieringskosten van het scholingsprogramma over de onderzoeksperiode het breakeven-point bereikt wordt na 6.1 jaar (zie figuur 5.2).

KOSTEN

BATEN

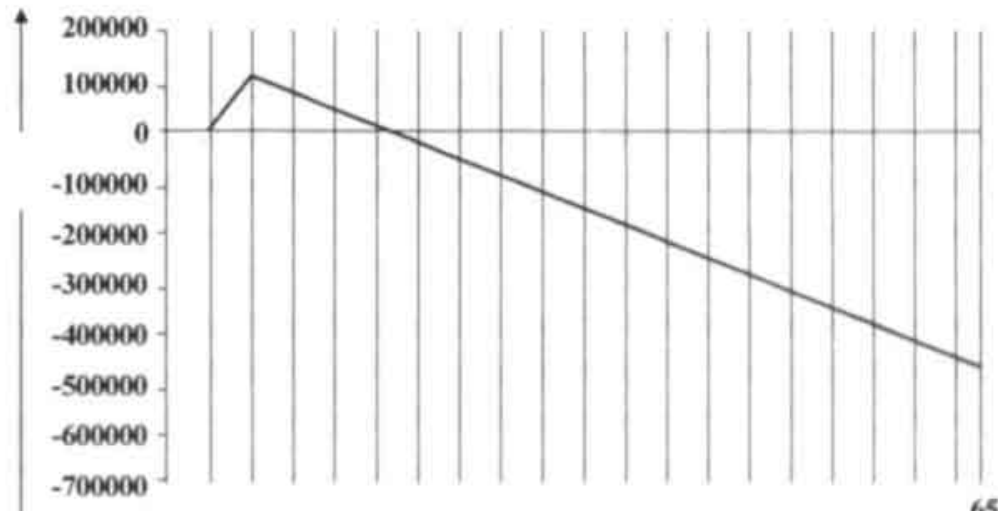

$26283032343638404244464850525456586062 \quad 64^{65}$

\section{LEEFTIJD}

Figuur 5.2 Kosten versus baten 
Uitgaande van een gemiddelde leeftijd van 30 jaar bij afronding van het scholingsprogramma, c.q. het vinden van een baan op korte termijn, zijn de oudcursisten op het break-even point gemiddeld 36 jaar. Op dat moment is de besparing aan uitkeringskosten gelijk aan de totale scholingskosten (zie figuur 5.2). Gezien het feit dat niet alle baten (sociale baten, verminderde kosten aan gezondheidszorg, hogere belastingopbrengst ten gevolge van de gestegen inkomens en dergelijke) meegenomen kunnen worden is dit een conservatieve inschatting.

Samenvattend heeft driekwart van de oud-cursisten na succesvolle afronding van het scholingsprogramma betaald werk in een baan die grotendeels aansluit op het gevolgde scholingsprogramma, zowel qua inhoud als qua niveau. Cursisten vinden enerzijds werk door het solliciteren op reguliere vacatures of het versturen van open sollicitaties, anderzijds door bemiddelingsactiviteiten van derden. Oud-cursisten vinden voornamelijk werk in de dienstverlenende sector en bij productie/productieverwerkende bedrijven.

Volgens werkgevers zjin de oud-cursisten aangenomen vanwgy chur valumation vaardigheden en/of hun persoonlijkheid, waarbij in een aantal gevallen tevens het handicapbeleid in de organisatie een rol heeft gespeeld. Werkgevers hebben vrijwel geen gebruik gemaakt van wettelijke regelingen en instrumenten ondanks dat ze hiertoe de mogelijkheid hebben.

Minder dan de helft van de oud-cursisten heeft aanpassingen in de werksituatie nodig. waarbij moet worden gedacht aan aanpassingen van de werkplek, aanpassingen van het takenpakket, aanpassingen van de werktijden en ondersteuning en begeleiding van collega's en leidinggevenden.

Volgens driekwart van de werkgevers functioneren de gereïntegreerde werknemers op gelijk of hoger niveau in vergelijking met collega's die hetzelfde of vergelijkbaar werk verrichten en geen beperkingen hebben. Werkgevers zijn van mening dat de sfeer niet of op een positieve wijze is beïnvloed door de komst van deze werknemer, hetgeen blijkt uit een betere werksfeer en meer respect en begrip voor elkaar.

De helft van de oud-cursisten heeft een uitkering. Dit geldt voor een derde deel van de werkenden. waarbij de uitkering gemiddeld $32 \%$ van het totale inkomen beslaat. $\mathrm{Na}$ ongeveer zes jaar blijken naar schatting, de besparingen aan uitkeringen overeen te komen met de kosten van het scholingsprogramma. De oud-cursisten zijn op het breakeven point gemiddeld 36 jaar en in potentie nog een groot aantal jaren actief participerend op de arbeidsmarkt. 
Concluderend kan worden gesteld dat de diverse centra, die op verschillende wijze hun scholingsprogramma's vormgeven en die verschillen in hun cursistenpopulaties, vergelijkbare resultaten opleveren. Hetgeen er op wijst dat de benadering van een intensief en uitvoerig scholingsprogramma an sich een factor is die het succes van arbeidsintegratie van mensen met een chronische arbeidshandicap verklaart. 



\section{PARTICIPATIE GEANALYSERRD}

\subsection{INLEIDING}

In de voorgaande hoofdstukken 4 en 5 zijn de drie factoren waarmee in dit proefschrift participatie is gedefinieerd, beschreven. In onderhavig hoofdstuk wordt antwoord gegeven op de vragen 4 en 5 van de in dit proefschrift beschreven studie, waarbij gebruik wordt gemaakt van het in paragraaf 2.7 gepresenteerde analysemodel voor het proces van arbeidsintegratie (figuur 6.1).

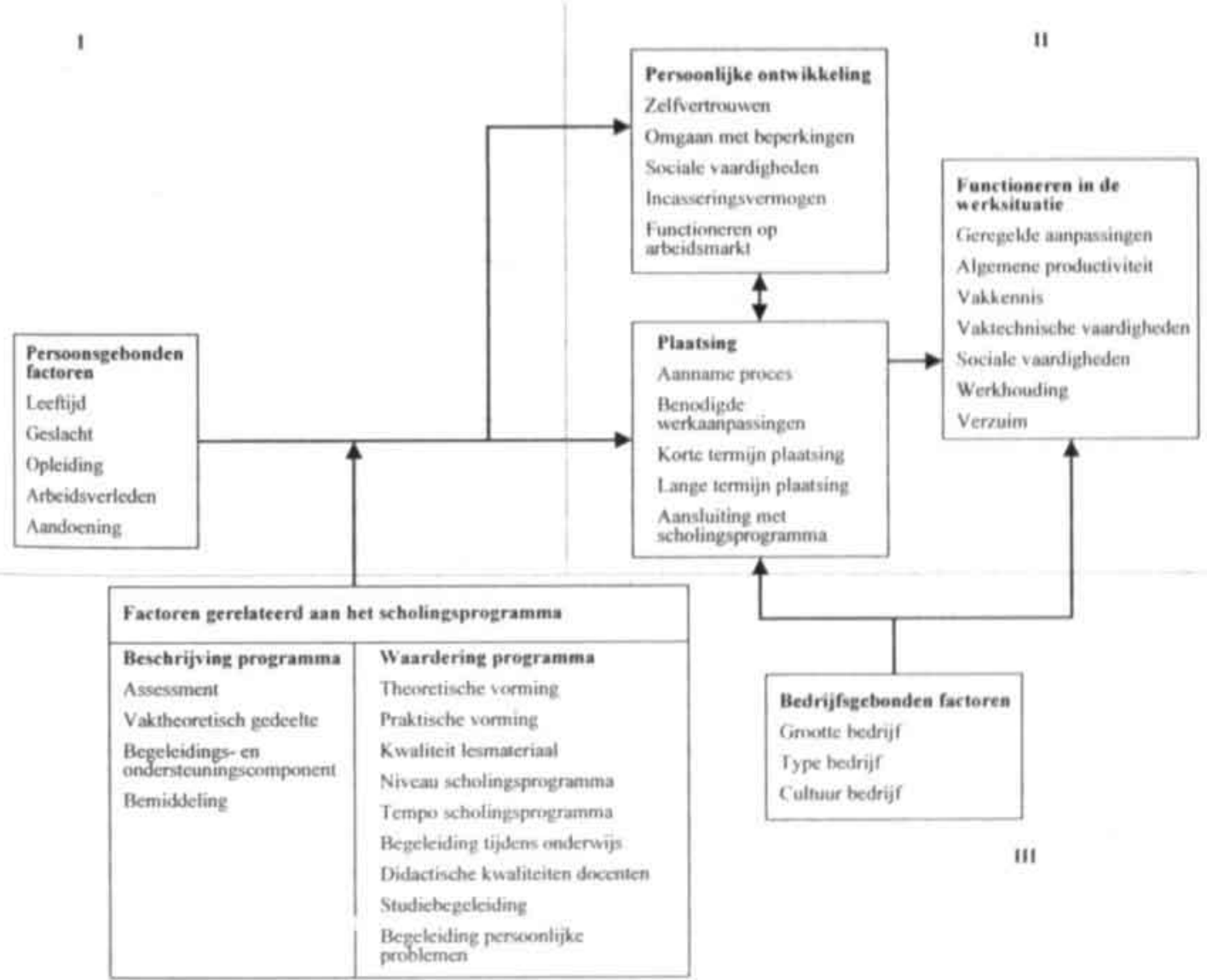

Figuur 6.1 Analysemodel voor het proces van arbeidsreintegratic 
Het betreft de beantwoording van de volgende onderzoeksvragen:

4 In welke mate blijken persoonsgebonden factoren bij te dragen aan het resultaat van het scholingsprogramma, zijnde een toename in de persoonlijke ontwikkeling, plaatsing op de reguliere arbeidsmarkt en succesvol functioneren in de werksituatie?

$5 \quad$ In welke mate dragen de verschillende elementen van het scholingsprogramma, namelijk de vaktheoretische component en de begeleidings- en ondersteuningscomponent bij aan het resultaat van het scholingsprogramma, zijnde een toename in de persoonlijke ontwikkeling, plaatsing op de reguliere arbeidsmarkt en succesvol functioneren in de werksituatie?

In dit model wordt een relatie gelegd tussen persoonsfactoren, het scholingsprogramma, de doorgemaakte persoonlijke ontwikkeling, plaatsing op korte en lange termijn en het functioneren in de werksituatie.

In eerste instantie zal binnen de factoren op item niveau worden gekeken naar verbanden om meer inzicht te krijgen in de onderlinge samenhang. Vervolgens zal. daar waar mogelijk, op schaalniveau verder worden geanalyseerd.

In paragraaf 6.2 wordt ingegaan op de relatie tussen de persoonsgebonden factoren en de drie factoren van participatie (persoonlijke ontwikkeling, plaatsing en functioneren in de werksituatie), waarna vervolgens in paragraaf 6.3 de invloed van de factoren gerelateerd aan het scholingsprogramma op de persoonlijke ontwikkeling van de oudcursisten worden beschreven, alsmede de invloed hiervan op de plaatsing op korte en op de lange termijn en het functioneren in de werksituatie. In paragraaf $6.4 \mathrm{zal}$ tenslotte de relatie tussen de drie factoren worden beschreven.

\subsection{PERSOONSGEBONDEN FACTOREN}

Bij een analyse van de invloed van persoonsgebonden factoren op succesvolle participatic (zie figuur 6.2). wordt in eerste instantie gekeken naar de relatie tussen persoonsgebonden factoren en persoonlijke ontwikkeling. Vervolgens wordt gekeken in hoeverre persoonsgebonden factoren een relatie hebben met plaatsing op korte termijn en plaatsing op lange termijn. Tenslotte zal worden beschreven in hoeverre persoonsgebonden factoren van invloed zijn op het functioneren in de werksituatie. 


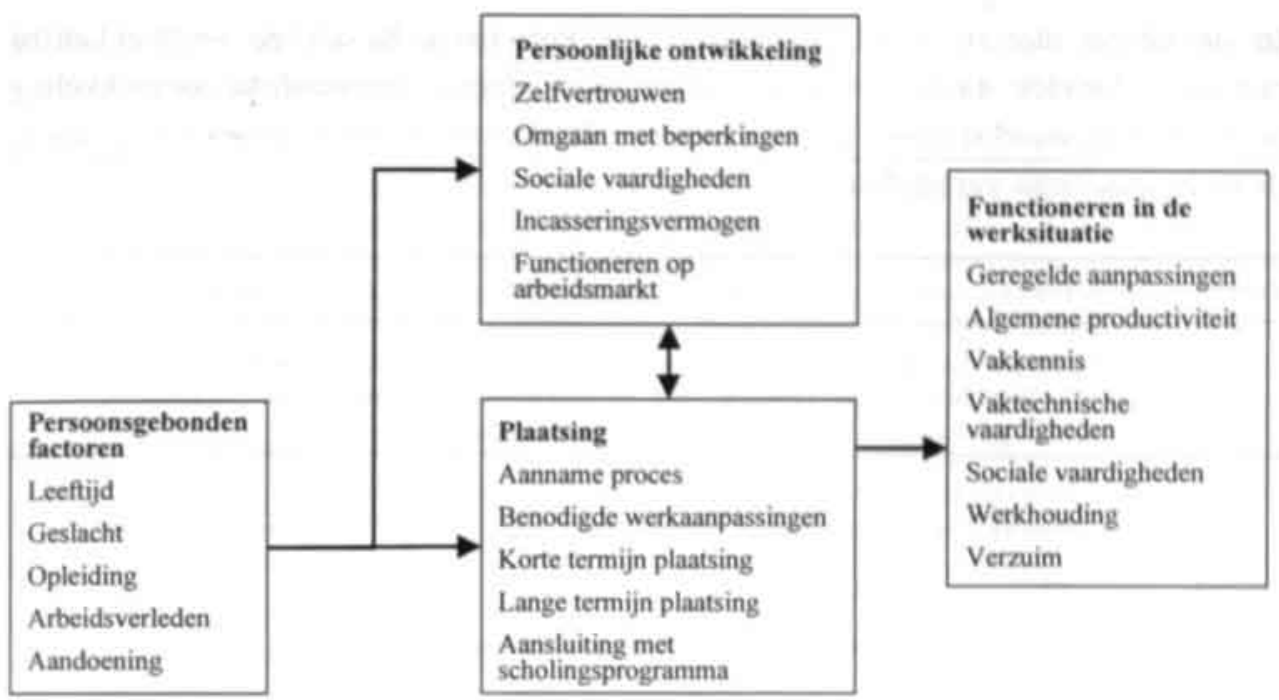

Figuur 6.2 Relatie persoonsgebonden factoren en participatic

\section{Persoonsgebonden factoren en persoonlijke ontwikkeling}

In de hiernavolgende tabellen 6.1 en 6.2 wordt een overzicht gegeven van de mogelijke verbanden binnen respectievelijk de persoonsgebonden factoren en de variabelen binnen de factor persoonlijke ontwikkeling. Gezien het nominale karakter van de variabele 'aandoening', is deze uit de analyse gelaten.

Tabel 6.1 Correlaties tussen de persoonsgebonden factoren leeftijd. geslacht, hoogste opleiding (voorafgaande aan het scholingsprogramma) en arbeidsverieden ( $\mathrm{n}=504)$

\begin{tabular}{lccc}
\hline & Leeftijd & Geslacht & Hoogste opl. \\
Geslacht & -.01 & & \\
Hoogste opleiding & $.14 * *$ & $.17 *$ & $-.09 *$ \\
Arbeidsverleden & $.53 *$ & $-.18 * *$ & - \\
\hline
\end{tabular}
* p $\leq 0.01$

Naarmate cursisten ouder zijn, is hun opleidingsniveau voorafgaande aan het scholingsprogramma hoger en hebben ze meer gewerkt. Daarnaast hebben meer mannen dan vrouwen, voorafgaande aan het scholingsprogramma gewerkt en zijn vrouwen relatief hoger opgeleid dan mannen. 
In de hiernavolgende tabel 6.2 worden de correlaties tussen de onafhankelijke persoonsgebonden factoren en de afhankelijke factor persoonlijke ontwikkeling weergegeven, waarbij zowel de correlatie op schaalniveau wordt weergegeven alsmede de meer specifieke verbanden.

\begin{tabular}{|c|c|c|c|c|c|c|}
\hline \multirow[t]{2}{*}{ Tabel 6.2} & \multicolumn{6}{|c|}{$\begin{array}{l}\text { Correlaties tussen de onafhankelijke persoonsgebonden factoren leeftijd, geslacht, hoogste } \\
\text { opleiding (voorafgaande aan het scholingsprogramma) en arbeidsverieden en de aftankelijke factor } \\
\text { persoonlijke ontwikkeling, alsmede de individuele afhankelijke variabelen binnen de factor } \\
\text { persoonlijke ontwikkeling, zelfvertrouwen, omgaan met beperkingen, sociale vaardigheden, } \\
\text { incasseringsvermogen en functioneren op de arbeidsmarkt ( } \mathrm{n}=504)\end{array}$} \\
\hline & $\begin{array}{l}\text { Persoonlijke } \\
\text { ontwikkeling }\end{array}$ & $\begin{array}{l}\text { Zelf- } \\
\text { vertrouwen }\end{array}$ & $\begin{array}{l}\text { Omgaan met } \\
\text { beperkingen }\end{array}$ & $\begin{array}{l}\text { Sociale } \\
\text { vaardigheden }\end{array}$ & $\begin{array}{l}\text { Incasserings- } \\
\text { vermogen }\end{array}$ & $\begin{array}{l}\text { Functioneren } \\
\text { arbeidsmarkt }\end{array}$ \\
\hline Leeftijd & .02 & -.06 & -.06 & $.10^{\circ}$ & .08 & .04 \\
\hline Geslacht & .04 & .02 & .00 & -.04 & -.05 & .00 \\
\hline Hoogste opl. & .01 & .04 & -.01 & 01 & .00 & .00 \\
\hline Arbeidsverleden & 06 & -.09 & $-.10^{*}$ & .00 & .00 & .03 \\
\hline
\end{tabular}

$0.01<p \leq 0.05$

Naarmate de oud-cursisten ouder zijn, geven ze aan door het scholingsprogramma meer sociale vaardigheden ontwikkeld te hebben. Oud-cursisten zonder arbeidsverleden geven aan beter geleerd te hebben om 'om te kunnen gaan' met hun beperkingen.

De overige onafhankelijke variabelen tonen geen verband met de persoonlijke ontwikkelingsvariabelen, hetgeen impliceert dat de persoonskenmerken relatief weinig van invloed zijn op het effect van het scholingsprogramma op de persoonlijke ontwikkeling. Analyse op centrumniveau geeft vrijwel geen afwijkend beeld dan het hier geschetste (zie de tabellen 6.2a - 6.2e van de bijlage).

Een multiple lineaire regressie analyse laat vervolgens zien dat geen van de variabelen voorspellend is voor de persoonlijke ontwikkeling.

\section{Persoonsgebonden factoren en plaatsing}

Binnen de factor plaatsing correleren de variabelen plaatsing op korte termijn en plaatsing op lange termijn met elkaar $(r=0.45, p<0.05)$. Oud-cursisten die op korte termijn werk hebben gevonden, zijn vaker werkzaam op lange termijn. De variabele aansluiting scholingsprogramma is een gesommeerde variabele van de twee variabelen aansluiting baan op theoretisch en aansluiting op praktisch gebied $($ alpha $=0.75)$. 
In de hiernavolgende tabel 6.3 wordt een overzicht gegeven van de mogelijke verbanden tussen de persoonsgebonden factoren en de plaatsingsvariabelen.

\begin{tabular}{|c|c|c|c|c|}
\hline \multirow[t]{2}{*}{ Tabel 6.3} & \multicolumn{4}{|c|}{$\begin{array}{l}\text { Correlaties tussen de onafhankelijke persoonsgebonden factoren leeftijd, geslacht, hoogste } \\
\text { opleiding (voorafgaande aan het scholingsprogramma) en arbeidsverieden en de individuele } \\
\text { afhankelijke variabelen binnen de factor plaatsing, namelijk aanpassingen, werk op korte termijn, } \\
\text { werk op lange termijn en aansluiting van baan bij het scholingsprogramma ( } n=504)\end{array}$} \\
\hline & $\begin{array}{l}\text { Aantal } \\
\text { aanpassingen }\end{array}$ & $\begin{array}{l}\text { Werk op korte } \\
\text { termijn }\end{array}$ & $\begin{array}{l}\text { Werk op } \\
\text { lange termijn }\end{array}$ & $\begin{array}{l}\text { Aansluiting van baan bij } \\
\text { scholingsprogramma }\end{array}$ \\
\hline Leeftijd & 00 & 08 & .06 & .04 \\
\hline Geslacht & $.09^{*}$ & .00 & $-.11^{\circ}$ & .01 \\
\hline Hoogste opl. & $10^{\circ}$ & .03 & $-.13 * *$ & .01 \\
\hline Arbeidsverleden & -.09 & .03 & .04 & .00 \\
\hline
\end{tabular}

$0.01<\mathrm{p} \leq 0.05$

* $\quad 0.001<\mathrm{p} \leq 0.01$

Mannen hebben, in strijd met de gegevens bekend uit de literatuur, in vergelijking met vrouwen, minder aanpassingen nodig. Dit geldt eveneens voor werknemers met een lager opleidingsniveau, voorafgaande aan het scholingsprogramma. Partiële correlatie wijst uit dat de samenhang tussen opleidingsniveau en geslacht niet de verklaring vormt voor de afzonderlijke samenhang tussen geslacht, opleidingsniveau en het totaal aantal aanpassingen, hetgeen overeenstemt met de literatuur. Analyse op basis van diagnose corrigeert voor hoogste opleiding in relatie tot het totaal aantal aanpassingen. maar niet voor geslacht. Waarschijnlijk zijn voor de gevonden samenhang andere dan de onderzochte variabelen verantwoordelijk.

Mannen zijn, in vergelijking met vrouwen, meer werkzaam op de lange termijn. In strijd met wat uit eerder onderzoek bekend is, geldt dit eveneens voor oud-cursisten met een lager opleidingsniveau, voorafgaande aan het scholingsprogramma. Gezien de samenhang tussen opleidingsniveau en geslacht (vrouwen zijn hoger opgeleid) kan de verklaring mogelijk hierin gelegen zijn. Ook hier wijst partiële correlatie uit dat dit niet het geval is.

Uit de analyses op centrumniveau blijken de jongere cursisten van Hoensbroeck meer aan het werk te zijn op de korte en de lange termijn. De cursisten van Heliomare zonder arbeidsverleden zijn, in vergelijking met diegenen mét een arbeidsverleden, méér aan het werk op de korte termijn. Voor het overige worden geen andere verbanden gevonden dan de in tabel 6.3 gepresenteerde verbanden (zie de tabellen $6.3 \mathrm{a}-6.3 \mathrm{e}$ van bijlage 1$)$. 
Toetsing met behulp van logistische regressie en multiple lineaire regressie wijst uit dat cursisten met een arbeidsverleden, een grotere kans hebben op werk op zowel korte als lange termijn. Daarnaast is de kans op werk op zowel korte als lange termijn groter, naarmate cursisten jonger zijn, hetgeen overeenstemt met de gegevens uit de literatuur (zie tabel 6.4). Deze algemene bevindingen komen overeen met de bevindingen op centrumniveau (zie de tabellen 6.4a - 6.4e van bijlage 1). Partiële correlatie wijst uit dat de samenhang tussen leeftijd en het al dan niet hebben gewerkt voorafgaande aan het scholingsprogramma niet van invloed is op deze bevindingen. De samenhang tussen geslacht en arbeidsverleden is eveneens niet van invloed.

Cursisten die hoger zijn opgeleid, voorafgaande aan het scholingsprogramma, hebben meer aanpassingen nodig. Daarnaast blijkt dat vrouwen relatief meer aanpassingen nodig hebben dan mannen (zie tabel 6.5).

\begin{tabular}{|c|c|c|c|c|}
\hline \multirow[t]{3}{*}{ Tabel 6.4} & \multicolumn{4}{|c|}{$\begin{array}{l}\text { Logistische regressievergelijking van de onafhankelijke persoonsgebonden factoren leeftijd, } \\
\text { geslacht, hoogste opleiding (voorafgaande aan het scholingsprogramma) en arbeidsverleden ten } \\
\text { aanzien van werk op korte en/of lange termijn ( } \mathrm{n}=504)\end{array}$} \\
\hline & \multicolumn{2}{|c|}{ Werk op korte termijn } & \multicolumn{2}{|c|}{ Werk op lange termijn } \\
\hline & $\mathrm{B}(\mathrm{S} . \mathrm{E})$. & $\operatorname{Exp}(B)$ & B (S.E.) & $\operatorname{Exp}(B)$ \\
\hline Leeftijd & $-.05(.02)^{\bullet}$ & $.96 * 0$ &. $.04(.02)^{*}$ & $96^{\circ}$ \\
\hline Geslacht & $.11(.25)$ & 1.12 & $-.38(.25)$ & .68 \\
\hline Hoogste opl. & $-.02(.11)$ & .99 & $-.18(.11)$ & .83 \\
\hline Arbeidsverleden & $.58(.27)^{*}$ & $1.78^{\circ}$ & $.65(.28)^{*}$ & $1.92^{\circ}$ \\
\hline
\end{tabular}

$0.01<p \leq 0.05$

*. $\quad 0.001<p \leq 0.01$

Tabel 6.5 Multiple lineaire regressie van de onafhankelijke persoonsgebonden factoren leeftijd, geslacht, hoogste opleiding (voorafgaande aan het scholingsprogramma) en arbeidsverleden ten aanzien van het benodigde aantal aanpassingen en de mening over aansluiting van de baan op het scholingsprogramma ( $n=504)$

Totaal aantal benodigde aanpassingen Aansluiting programma op baan

\begin{tabular}{lllll}
\hline & $\Delta \mathrm{R}^{2}$ & $\beta$ & $\Delta \mathrm{R}^{2}$ & $\beta$ \\
\hline Leeftijd & & - & $\mathrm{ns}$ & ns \\
Geslacht & $01^{*}$ & $.09^{*}$ & - & - \\
Hoogste opl. & $.02 *$ & $09^{*}$ & - & - \\
Arbeidsverleden & - & - & - & \\
\hline
\end{tabular}


Samenvattend wordt de toegenomen persoonlijke ontwikkeling niet verklaard door persoonsgebonden factoren. Daarentegen wordt het vinden en behouden van werk deels verklaard door een jongere leeftijd en een arbeidsverleden, en wordt het aantal aanpassingen genoemd door cursisten zelf en door werkgevers deels verklaard door opleiding voorafgaande aan het scholingsprogramma en geslacht.

\section{Persoonsgebonden factoren en functioneren in de werksituatie}

Allereerst is gekeken naar mogelijke verbanden tussen de variabelen behorende tot de factor 'functioneren in de werksituatie' (tabel 6.6).

Tabel 6.6 Correlaties tussen de variabelen binnen de factor 'functioneren in de werksituatie', aanpassingen (werkplek, takenpakket, werktijden en steun van collega's), algemene productiviteit, vakkennis, vaktechnische vaardigheden, sociale vaardigheden, werkhouding en verzuim ( $n=75$ )

werkpiek taken- werk- steun algemene vakkennis vaktechnische sociale werkpakket tijden productiviteit vaardigheden vaardigheden houding

\begin{tabular}{|c|c|c|c|c|c|c|c|c|c|}
\hline Takenpakket & $38 * 0$ & & & & & & & & \\
\hline Werktijden & $.33 *$ & $.34 * 0$ & & & & & & & \\
\hline Stcun & $36 *$ & $.24^{*}$ & .05 & & & & & & \\
\hline $\begin{array}{l}\text { Algemene } \\
\text { productiviteit }\end{array}$ & -.25 & $-.33 *$ & -.08 & $-.52 *$ & & & & & \\
\hline Vakkennis & -17 & .03 & -.04 & -.19 & $36 *$ & & & & \\
\hline $\begin{array}{l}\text { Vaktechnische } \\
\text { vaardigheden }\end{array}$ & -01 & .09 & .04 & -03 & .26 & $.52 *$ & & & \\
\hline $\begin{array}{l}\text { Sociale } \\
\text { vaardigheden }\end{array}$ & $-35 * *$ & $-.39 \bullet \bullet$ & -.09 & -.08 & .20 & -.13 & -.06 & & \\
\hline Werkhouding & -.14 & $-26^{\circ}$ & .05 & .03 & $.43 *$ & .17 & $.35 *$ & $39 * *$ & \\
\hline Verzuim & .18 & -08 & .16 & -.03 & -.19 & .77 & -.13 & .14 & -19 \\
\hline
\end{tabular}

De verschillende typen aanpassingen van de werksituatie correleren vrijwel allemaal significant met elkaar. Deze zijn gesommeerd tot een schaal 'aanpassingen' (alpha = .62). Tussen de variabelen vakkennis, vaktechnische vaardigheden, werkhouding en algemene productiviteit blijkt een significant verband te bestaan. Ook deze variabelen zijn gesommeerd tot een schaal 'vakinhoudelijk functioneren' (alpha $=.71$ ). Uit tabel 6.6 kan tevens worden afgelezen dat het door de werkgever beoordeelde verzuim en 
sociale vaardigheden van de gereïntegreerde werknemer relatief onafhankelijk plaatsvindt van de beoordeling van de vakinhoudelijke vaardigheden.

Naarmate de gereïntegreerde werknemer meer aanpassingen nodig heeft van het takenpakket blijkt de werkgever een lagere beoordeling te geven van de sociale vaardigheden, de werkhouding en de algemene productiviteit. Daarnaast blijkt meer behoefte aan steun van collega's gepaard te gaan met een lagere beoordeling van de algemene productiviteit.

Het functioneren in de werksituatie wordt slechts in beperkte mate beïnvloed door de persoonsgebonden factoren (tabel 6.7).

Meer vrouwen dan mannen blijken volgens de werkgevers werkaanpassingen nodig te hebben. Het betreft voornamelijk aanpassingen van meubilair en/of apparatuur.

\begin{tabular}{|c|c|c|c|c|c|}
\hline \multirow[t]{2}{*}{ Tabel 6.7} & \multicolumn{5}{|c|}{$\begin{array}{l}\text { Correlaties tussen de persoonsgebonden factoren leeftijd, geslacht, hoogste opleiding } \\
\text { (voorafgaande aan het scholingsprogramma) en arbeidsverleden en de individuele variabelen } \\
\text { binnen de factor 'functioneren in de werksituatie': aanpassingen, vakinhoud, sociale vaardigheden } \\
\text { en verzuim ( } n=75 \text { ) }\end{array}$} \\
\hline & & aanpassingen & vakinhoud & sociale vaardigheden & verzuim \\
\hline Leeftijd & & -.04 & .15 & -.09 & .15 \\
\hline Geslacht & & $29^{\circ}$ & -19 & 08 & -.13 \\
\hline \multicolumn{2}{|c|}{ Hoogste opleiding } & .15 & .12 & -.06 & -.02 \\
\hline \multicolumn{2}{|c|}{ Arbeidsverleden } & $-.26^{\circ}$ & .17 & .02 & .04 \\
\hline
\end{tabular}

$0.01<\mathrm{p} \leqslant 0.05$

Gereïntegreerde werknemers die voorafgaande aan het scholingsprogramma niet hebben gewerkt, blijken meer aanpassingen nodig te hebben dan werknemers die van tevoren wel hebben gewerkt. Het functioneren in de werksituatie blijkt verder niet te worden beinvloed door persoonsgebonden factoren.

Toetsing met behulp van multiple lineaire regressie wijst uit dat volgens werkgevers, vrouwen in vergelijking met mannen, meer aanpassingen nodig hebben (tabel 6.8).

Daarnaast blijkt dat gereïntegreerde werknemers met een arbeidsverleden, minder aanpassingen nodig hebben. De persoonsgebonden factoren blijken verder niet voorspellend voor de overige afhankelijke variabelen vakinhoudelijk functioneren, sociale vaardigheden en verzuim. 
Tabel 6.8 Multiple lineaire regressie van de persoonsgebonden factoren leeftijd, geslacht, opleiding en arbeidsverleden op de door de werkgever beoordeelde werkaanpassingen, vakinhoudelijk functioneren, sociale vaardigheden en verzuim van de gereîntegreerde werknemer $(n=75)$,

\begin{tabular}{|c|c|c|c|c|c|c|c|c|}
\hline & \multicolumn{2}{|c|}{$\begin{array}{l}\text { Totaal benodigde } \\
\text { aanpassingen }\end{array}$} & \multicolumn{2}{|c|}{$\begin{array}{l}\text { Vakinhoudelijk } \\
\text { functioneren }\end{array}$} & \multicolumn{4}{|c|}{ Sociale vaardigheden Verzuim } \\
\hline & $\Delta R^{2}$ & $\beta$ & $\Delta \mathbf{R}^{2}$ & $\beta$ & $\Delta \mathbf{R}^{2}$ & $\beta$ & $\Delta \mathbf{R}^{2}$ & $\beta$ \\
\hline Leeftijd & .03 & 21 & - & .09 & - & .09 & - & .11 \\
\hline Geslacht & $.10^{*}$ & $31^{*}$ & $\cdot$ & -.19 & $\cdot$ & .08 & - &,- 15 \\
\hline Hoogste opl. & .01 & .11 & - & .15 & - & .06 & - & .02 \\
\hline Arbeidsverleden & $.05^{*}$ & $-.22^{*}$ & - & .14 & - & .05 & - & .03 \\
\hline
\end{tabular}

$0.01<p \leq 0.05$

\subsection{FACTOREN GERELATEERD AAN HET SCHOLINGSPROGRAMMA}

Bij een analyse van de invloed van de interventiegebonden factoren op succesvolle participatie (zie figuur 6.3), wordt in eerste instantie gekeken naar de relatie tussen de variabelen binnen het scholingsprogramma en persoonlijke ontwikkeling. Vervolgens wordt onderzocht in hoeverre de variabelen binnen het scholingsprogramma een relatic hebben met plaatsing op korte termijn en plaatsing op lange termijn. Tenslotte zal worden beschreven in hoeverre de variabelen binnen het scholingsprogramma van invloed zijn op het functioneren in de werksituatie.

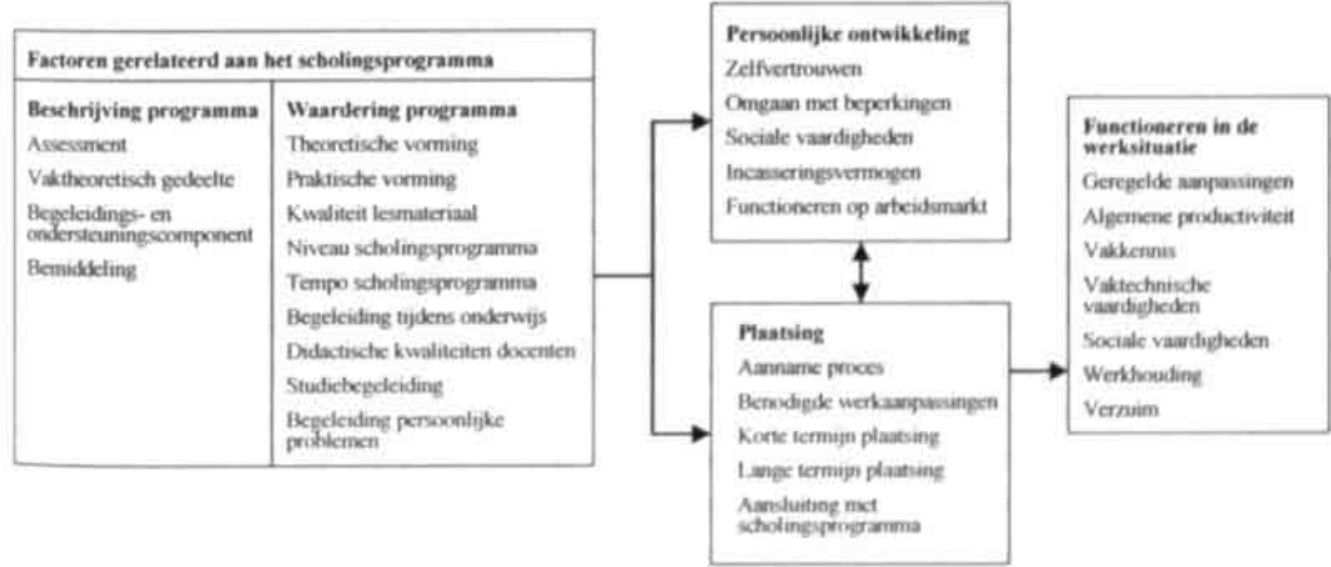

Figuur 6.3 Relatie variabelen binnen het scholingsprogramma en participatic 


\section{Het scholingsprogramma in relatie tot de persoonlijke ontwikkeling}

De variabelen binnen het scholingsprogramma hangen sterk samen (tabel 6.9). Oudcursisten die tevreden zijn over het niveau en het tempo van het scholingsprogramma, uiten hun tevredenheid eveneens over de praktische en theoretische vorming, de kwaliteit van het lesmateriaal alsmede de didactische kwaliteiten van de docenten.

Tabel 6.9 Correlaties tussen de variabelen binnen het scholingsprogramma: theoretische vorming, praktische
vorming, kwaliteit lesmateriaal, niveau scholingsprogramma, tempo scholingsprogramma,
begeleiding tijdens onderwijs, didactische kwaliteiten docenten, studiebegeleiding en begeleiding
tijdens persoonlijke problemen (n=504)

Alhoewel sprake is van afzonderlijke componenten van het scholingsprogramma, lijkt het erop dat sprake is van een algeheel beeld van de cursisten omtrent de inhoud en organisatie van de scholing. Vanwege de sterke samenhang is, op basis van factor analyse (principale componenten analyse, varimax rotatie), gekozen voor een éénfactor oplossing 'aansluiting scholingsprogramma'(alpha $=.73$ ). De begeleiding bij persoonlijke problemen valt hierbij weg. Het wegvallen van de variabele begeleiding bij persoonlijke problemen is begrijpelijk omdat deze variabele iets zegt over de begeleidingsproblematiek, in tegenstelling tot de overige variabelen die zich richten op onderwijsstructuur en -inhoud.

Naarmate het scholingsprogramma meer aansluit bij de persoonlijke behoeften en capaciteiten van de oud-cursisten, oordelen zij positiever over hun persoonlijke ontwikkeling (tabel 6.10). Eveneens geldt dat naarmate de begeleiding bij persoonlijke 
problemen tijdens het scholingsprogramma meer aansluit bij de behoeften van de oudcursisten, er sprake is van een toegenomen persoonlijke ontwikkeling. Deze verbanden worden het sterkst aangetroffen bij EEGA (zie de tabellen $6.10 \mathrm{a}-6.10 \mathrm{e}$ van de bijlage).

Tabel 6.10 Correlaties tussen de variabelen van het scholingsprogramma en de variabelen binnen de factor persoonlijke ontwikkeling. $(\mathrm{n}=504)$.

\begin{tabular}{|c|c|c|c|c|c|c|}
\hline & $\begin{array}{l}\text { persoonlijke } \\
\text { ontwikkeling }\end{array}$ & $\begin{array}{l}\text { zelf- } \\
\text { vertrouwen }\end{array}$ & $\begin{array}{l}\text { omgaan met } \\
\text { beperkingen }\end{array}$ & $\begin{array}{l}\text { sociale } \\
\text { vaardigheden }\end{array}$ & $\begin{array}{l}\text { incasserings- } \\
\text { vermogen }\end{array}$ & $\begin{array}{l}\text { functioneren } \\
\text { arbeidsmarkt }\end{array}$ \\
\hline $\begin{array}{l}\text { Aansluiting } \\
\text { scholingsprogramma }\end{array}$ & $21^{* 0}$ & $.26 * 0$ & $.16 * 0$ & $.13 * 0$ & $.13^{\circ 0}$ & $.21 *$ \\
\hline $\begin{array}{l}\text { Begeleiding bij } \\
\text { persoonlijke problemen }\end{array}$ & $.24 * *$ & $26 * 0$ & $.22 * \bullet$ & $.09^{*}$ & $.18 * *$ & $.13 * 0$ \\
\hline Theoretische vorming & $.12 * \bullet$ &, $13 * \bullet$ & $.12 *$ & .06 & .07 & $.17 \%$ \\
\hline Praktische vorming & $.12 *$ & $.16 * *$ & .09 & .09 & .05 & $.20 *$ \\
\hline Kwaliteit lesmateriaal & .06 & .05 & .04 & .01 & $.10^{\circ}$ & $.10^{\circ}$ \\
\hline Niveau & $20 *$ & $.25 *$ & $.16 * 0$ & $10^{*}$ & $.12 *$ & $.17 *$ \\
\hline Tempo & $20 *$ & $.21 \%$ & $.14 * *$ & $.16 * 0$ & $.12 \%$ & $.21 \%$ \\
\hline Begeleiding onderwijs & $.11 \%$ & $.17 *$ & .06 & $.10^{\circ}$ & .03 & $.18 \%$ \\
\hline Didactische kwaliteit & .08 & $.11^{\circ}$ & $10^{*}$ & .02 & .04 & $.13 \cdots$ \\
\hline Studiebegeleiding & $.13 \%$ & $16 * 0$ & .07 & .06 & $.11^{\circ}$ & .02 \\
\hline
\end{tabular}

$0.01<\mathrm{p} \leq 0.05$

$\cdots \quad 0.001<p \leq 0.01$

De eigen beoordeling van het functioneren in op de arbeidsmarkt hangt positief samen met de aansluiting van het theoretisch en praktisch gedeelte van het scholingsprogramma op de persoonlijke behoeften en mogelijkheden van de oud-cursisten. Naarmate de aansluiting beter is, oordelen zij ook positiever over hun eigen functioneren op de arbeidsmarkt. Een toegenomen zelfvertrouwen hangt samen met een positief oordeel over de begeleiding bij persoonlijke problemen, het niveau en het tempo van het scholingsprogramma alsmede een positief oordeel over de studiebegeleiding.

Toetsing met behulp multiple lineaire regressie laat zien dat een positieve persoonlijke ontwikkeling wordt verklaard door de aansluiting van het scholingsprogramma op de persoonlijke behoeften en capaciteiten van de oud-cursisten en de aansluiting van de begeleiding op de behoefte van oud-cursisten met betrekking tot persoonlijke problemen (tabel 6.11). 
Tabel 6.11 Multiple lineaire regressie van de factoren gerelateerd aan het scholingsprogramma ten aanzien van de persoonlijke ontwikkeling $(n=504)$.

\begin{tabular}{lll}
\hline & Persoonlijke ontwikkeling \\
\hline & $\Delta \mathrm{R}^{2}$ & $\beta$ \\
\hline Aansluiting scholingsprogramma & $.05 * *$ & $.21 \cdots$ \\
Begeleiding bij persoonlijke problemen & $.04 \cdots$ & $.20 * \cdots$ \\
\hline$\ldots$ p $\leq 0.001$ &
\end{tabular}

De verklaarde variantie voor wat betreft de aansluiting scholingsprogramma is met name toe te wijzen aan de bijdrage van EEGA hierin (zie de tabellen 6.11a - 6.11e van de bijlage).

\section{Scholingsprogramma en plaatsing}

De mate waarin het scholingsprogramma overeenkomt met de behoeften en capaciteiten van de oud-cursisten, hangt significant samen met het vinden van werk op korte en lange termijn en de aansluiting van het scholingsprogramma op het werk (tabel 6.12).

\begin{tabular}{|c|c|c|c|c|}
\hline \multirow[t]{2}{*}{ Tabel 6.12} & \multicolumn{4}{|c|}{ s tussen de factoren gerelateerd aan het scholingsprogramma en de plaatsingsfactoren } \\
\hline & Aantal aanpassingen & $\begin{array}{l}\text { Werk op korte } \\
\text { termijn }\end{array}$ & $\begin{array}{l}\text { Werk op lange } \\
\text { termijn }\end{array}$ & $\begin{array}{l}\text { Aansluiting baan bij } \\
\text { scholingsprogramma }\end{array}$ \\
\hline $\begin{array}{l}\text { Aansluiting } \\
\text { scholingsprogramma }\end{array}$ & .14 & $.13 *$ & $.19 * 6$ & 220 \\
\hline $\begin{array}{l}\text { Begeleiding bij } \\
\text { persoonlijke problemen }\end{array}$ & .06 & $.14 * 0$ & .09 & .07 \\
\hline
\end{tabular}

*. $0.001<p \leqslant 0.01$

Bij de oud-cursisten die op korte en/of lange termijn werken, sluit het scholingsprogramma meer aan op de persoonlijke behoeften en capaciteiten. Oudcursisten die van mening zijn dat het de gevonden baan aansluit bij het scholingsprogramma, vinden eveneens dat het scholingsprogramma meer aansluit op hun persoonlijke behoeften en capaciteiten. Daarnaast hangt een positieve waardering over de begeleiding bij persoonlijke problemen samen met het vinden van werk op korte termijn. 
De uitkomsten op centrumniveau zijn veelal min of meer vergelijkbaar, echter niet altijd significant. De analyses van Hoensbroeck laten vrijwel geen verband zien tussen de gemeten variabelen (zie de tabellen 6.12a - 6.12e van de bijlage).

Toetsing met behulp van multiple lineaire regressie wijst uit dat werk op korte termijn, werk op lange termijn en de aansluiting van de verkregen baan bij het scholingsprogramma worden verklaard door de mate waarin het scholingsprogramma aansluit op de persoonlijke behoeften en capaciteiten van de oud-cursisten. Tevens wordt werk op korte termijn verklaard door de mate waarin de begeleiding bij persoonlijke problemen aansluit bij de behoeften van de oud-cursisten (tabel 6.13).

Tabel 6.13 Multiple lineaire regressie tussen de factoren gerelatecrd aan het scholingsprogramma en de plaatsingsfactoren $(\mathrm{n}=504)$

\begin{tabular}{llllllllll}
\hline & $\begin{array}{l}\text { Totaal benodigde } \\
\text { aanpassingen }\end{array}$ & $\begin{array}{l}\text { Werk op korte } \\
\text { termijn }\end{array}$ & \multicolumn{2}{l}{$\begin{array}{l}\text { Werk op lange } \\
\text { termijn }\end{array}$} & \multicolumn{2}{l}{$\begin{array}{l}\text { Aansluiting baan bij } \\
\text { scholingsprogramma }\end{array}$} \\
\hline & $\Delta \mathrm{R}^{2}$ & $\beta$ & $\Delta \mathrm{R}^{2}$ & $\beta$ & $\Delta \mathrm{R}^{2}$ & $\beta$ & $\Delta \mathrm{R}^{2}$ & $\beta$ \\
\hline $\begin{array}{l}\text { Aansluiting } \\
\text { scholingsprogramma }\end{array}$ & .00 & .02 & $.02 *$ & $.13 *$ & $.04 * *$ & $.19 * \cdots$ & $.05 * *$ & $.22 * *$ \\
$\begin{array}{l}\text { Begeleiding bij } \\
\text { persoonlijke problemen }\end{array}$ & .00 & .07 & .01 & $.11^{*}$ & .00 & .03 & $.02 *$ & $.16 * *$ \\
\hline
\end{tabular}

$0.01<\mathrm{p} \leq 0.05$

$* \quad 0.001<\mathrm{p} \leq 0.01$

$\cdots p \leq 0.001$

Op centrumniveau zijn de relaties tussen de factoren gerelateerd aan het scholingsprogramma en de plaatsingsfactoren niet altijd herkenbaar (zie de tabellen $6.13 \mathrm{a}-6.13 \mathrm{e}$ van de bijlage).

\section{Scholingsprogramma en functioneren in de werksituatie}

Een betere aansluiting van de begeleiding tijdens het onderwijs op de persoonlijke behoeften van de oud-cursisten, hangt samen met een hoger aantal gerealiseerde werkaanpassingen door de werkgevers (tabel 6.14).

Er bestaat tevens een positieve samenhang tussen het oordeel van werkgevers over de sociale vaardigheden van de werknemer en een goede aansluiting van de scholing op de persoonlijke behoeften en capaciteiten van de oud-cursist. Ook blijkt dat naarmate oud-cursisten meer positief zijn over de studiebegeleiding, werkgevers meer positief zijn over de sociale vaardigheden van de gereïntegreerde werknemer. 
Tabel 6.14 Correlaties tussen de factoren gerelateerd aan het scholingsprogramma en de factoren met betrekking tot het functioneren in de werksituatie $(n=75)$

Aanpassingen Vakinhoudelijk Sociale vaardigheden Verzuim functioneren

\begin{tabular}{lcccc} 
Aansluiting scholingsprogramma & .22 & .05 & .11 & .10 \\
Begeleiding bij persoonlijke problemen & .21 & .17 & .04 & .07 \\
Theoretische vorming & .13 & .05 & .19 & .05 \\
Praktische vorming & .19 & .11 & .02 & .00 \\
Kwal. lesmateriaal & .01 & .05 & .02 & .05 \\
Niveau & .16 & .12 & .02 & .06 \\
Tempo & .16 & .08 & .07 & .21 \\
Begeleiding onderwijs & $.28^{*}$ & .19 & .09 & .23 \\
Didactische kwaliteit & .16 & .02 & .04 & .13 \\
Studiebegeleiding & .03 & .10 & $.29 *$ & .08 \\
\hline
\end{tabular}

$0.01<p \leq 0.05$

Toetsing met behulp van multiple lineaire regressie laat zien dat de door de werkgever gerealiseerde aanpassingen deels worden verklaard door de opvatting van de oudcursisten omtrent de aansluiting van het scholingsprogramma en de begeleiding bij persoonlijke problemen op hun persoonlijke behoeften en capaciteiten (tabel 6.15).

Tabel 6.15 Multiple lineaire regressie van de factoren aansluiting scholingsprogramma en begeleiding bij persoonlijke problemen op de door de werkgever beoordeelde werkaanpassingen, vakinhoudelijk functioneren, sociale vaardigheden en verzuim van de gereìntegreerde werknemer ( $n=75)$.

\begin{tabular}{lcccccccc}
\hline & $\begin{array}{l}\text { Totaal benodigde } \\
\text { aanpassingen }\end{array}$ & $\begin{array}{l}\text { Vakinhoudelijk } \\
\text { functioneren }\end{array}$ & \multicolumn{5}{l}{ Sociale vaardigheden Verzuim } \\
\hline & $\Delta \mathbf{R}^{2}$ & $\beta$ & $\Delta \mathbf{R}^{2}$ & $\beta$ & $\Delta \mathbf{R}^{2}$ & $\beta$ & $\Delta \mathbf{R}^{2}$ & $\beta$ \\
\hline $\begin{array}{l}\text { Aansluiting } \\
\text { scholingsprogramma }\end{array}$ & $.05 *$ & $.22^{*}$ & .00 & .05 & .01 & .11 & .01 & .10 \\
$\begin{array}{l}\text { Begeleiding bij } \\
\text { persoonlijke problemen } .07^{*}\end{array}$ & $.27^{*}$ & .04 & -19 & .00 & .02 & .01 & .09 \\
\hline
\end{tabular}
$0.01<\mathrm{p}>0.05$

Minder werkaanpassingen zijn nodig voor werknemers die positiever oordelen over de aansluiting van het scholingsprogramma en de begeleiding. Het door de werkgevers 
beoordeelde vakinhoudelijk functioneren van de gereïntegreerde werknemers, sociale vaardigheden en verzuimgedrag worden niet verklaard door factoren gerelateerd aan het scholingsprogramma. Blijkbaar wordt werkgerelateerde gedrag door andere factoren beînvloed, zoals de arbeidsverhoudingen, de specifieke organisatiecultuur en dergelijke. Voor scholingsprogramma's geldt dat deze dus in staat moeten zijn om personen met een arbeidshandicap van voldoende vaardigheden te voorzien opdat zij zich in zeer verschillende werksituaties kunnen handhaven.

Samenvattend wordt een positieve persoonlijke ontwikkeling deels verklaard door de mate waarin het scholingsprogramma aansluit bij de behoeften en capaciteiten van de oud-cursisten. Meer specifiek bestaat een vrij sterke samenhang tussen enerzijds de mate waarin het niveau, het tempo van - en de begeleiding tijdens het scholingsprogramma beter aansluit op de behoeften en (on)mogelijkheden van de oudcursist en anderzijds een toegenomen zelfvertrouwen, het beter kunnen omgaan met de beperkingen en het functioneren op de arbeidsmarkt.

Het vinden van werk op zowel korte als lange termijn en het door de werkgever aangegeven aantal aanpassingen wordt deels verklaard door de interventiegebonden factoren, vertaald in de aansluiting van het scholingsprogramma en de begeleiding, op de persoonlijke behoeften en capaciteiten van de oud-cursisten. Daarnaast wordt het vinden van werk op korte termijn en het aantal door werkgevers aangegeven aantal werkaanpassingen, deels verklaard door de mate waarin de begeleiding bij persoonlijke problemen aansluit bij de behoeften van de oud-cursist, hetgeen kan duiden op de ernst van de aandoening. Het door de werkgevers beoordeelde vakinhoudelijk functioneren van de gereîntegreerde werknemers, sociale vaardigheden en verzuimgedrag worden niet verklaard door interventiegebonden factoren. Blijkbaar wordt dit werkgerelateerde gedrag door andere factoren beïnvloed, zoals de arbeidsverhoudingen, de specifieke organisatiecultuur en dergelijke. Voor scholingsprogramma's geldt dat deze dus in staat moeten zijn om personen met een arbeidshandicap van voldoende vaardigheden te voorzien opdat zij zich in zeer verschillende werksituaties kunnen handhaven.

\subsection{RELATIE BINNEN PARTICIPATIE}

De verschillende participatie-factoren correleren relatief laag en laten zien dat deze factoren betrekkelijk onafhankelijk zijn (tabel 6.16). Naarmate oud-cursisten positiever oordelen over hun persoonlijke ontwikkeling, zijn ze meer aan het werk, zowel op korte als op lange termijn. 
Daarnaast bestaat een sterke samenhang tussen de door de gereïntegreerde werknemer genoemde aanpassingen en de door de werkgever genoemde aanpassingen, hetgeen wijst op een hoge mate van overeenkomst tussen de verschillende metingen. De overige verbanden zijn reeds eerder aan de orde gekomen.

Tabel 6.16 Correlaties tussen de variabelen binnen de participatiefactoren'

persoonlijke aanpassing korte lange baan sluit aanpassing vakinhoud sociale ontwikkeling werknemers termijn termijn op scholing werkgevers vaardigheid vaardigheid

Aanpassingen werknemers .05

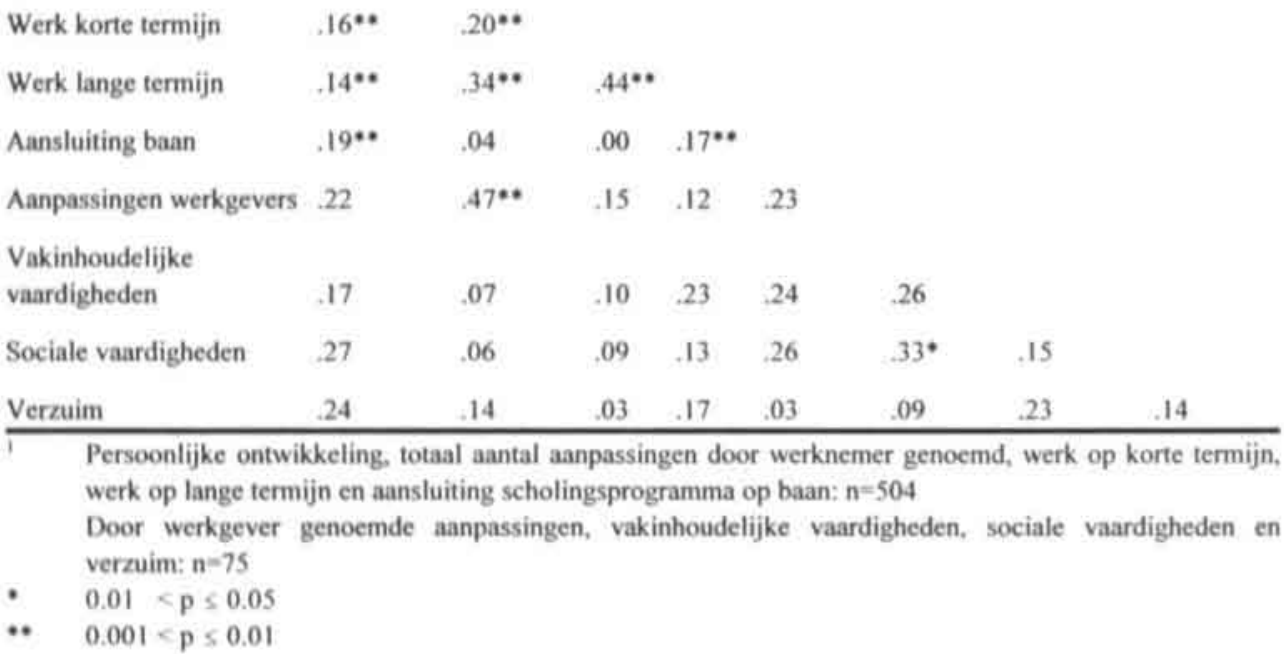

\section{Verklarende factoren voor plaatsing op korte termijn en op lange termijn}

Met behulp van een logistische regressievergelijking is onderzocht in hoeverre alle eerder genoemde verklarende variabelen, in samenhang met elkaar, het plaatsingssucces op korte en lange termijn verklaren. De kans op werk op korte termijn en op lange termijn is hoger indien de oud-cursist relatief jonger is, voorafgaande aan het scholingsprogramma gewerkt heeft, het scholingsprogramma beter aansluit bij de persoonlijke behoeften en capaciteiten van de oud-cursist en naarmate de oud-cursist positiever oordeelt over zijn/haar persoonlijke ontwikkeling (tabel 6.17).

Wanneer deze multivariate analyse op centrumniveau wordt uitgevoerd, blijkt dat bij Hoensbroeck met name de jongere leeftijd bepalend is, bij Werkenrode en Sonneheerdt speelt het arbeidsverleden een bepalende rol, bij Heliomare levert geen van de genoemde variabelen een significante bijdrage en bij EEGA blijkt de persoonlijke ontwikkeling het meest bepalend (zie de tabellen $6.17 \mathrm{a}-6.17 \mathrm{e}$ van de bijlage). 
Tabel 6.17 Logistische regressievergelijking van de onafhankelijke persoonsgebonden factoren leeftijd en arbeidsverleden, aansluiting van scholingsprogramma en persoonlijke ontwikkeling ten aanzien van werk op korte en op lange termijn ( $\mathrm{n}=504)$

\begin{tabular}{llllll}
\hline & \multicolumn{2}{l}{ Werk op korte termijn } & \multicolumn{2}{l}{ Werk op lange termijn } \\
& B (S.E.) & Exp (B) & B (S.E.) & Exp (B) \\
Leeftijd & $-.04(.02)^{*}$ & $.97^{*}$ & $-.04(.02)^{*}$ & $.96^{*}$ \\
Arbeidsverieden & $.48(.26)^{*}$ & $1.62^{*}$ & $.57(.27)^{*}$ & $1.78^{*}$ \\
Aansluiting scholingsprogramma & $.07(.03)^{*}$ & $.96^{*}$ & $.14(.03)^{* * *}$ & $.87^{* * *}$ \\
Persoonlijke ontwikkeling & $.09(.03)^{* *}$ & $.92^{* *}$ & $.06(.03)^{*}$ & $.94^{*}$ \\
\hline
\end{tabular}

$0.01<p \leq 0.05$

*. $\quad 0.001<\mathrm{p} \leq 0.01$

*.. $p \leq 0.001$

\section{Samenvattende bevindingen}

Op basis van de onderzoeksbevindingen kan worden geconcludeerd dat een jongere leeftijd samenhangt met een grotere kans op plaatsing op korte en lange termijn. Vrouwen blijken meer aanpassingen nodig te hebben dan mannen. Oud-cursisten met een arbeidsverleden hebben een grotere kans op plaatsing en oud-cursisten met een lager opleidingsniveau hebben minder aanpassingen nodig (figuur 6.4).

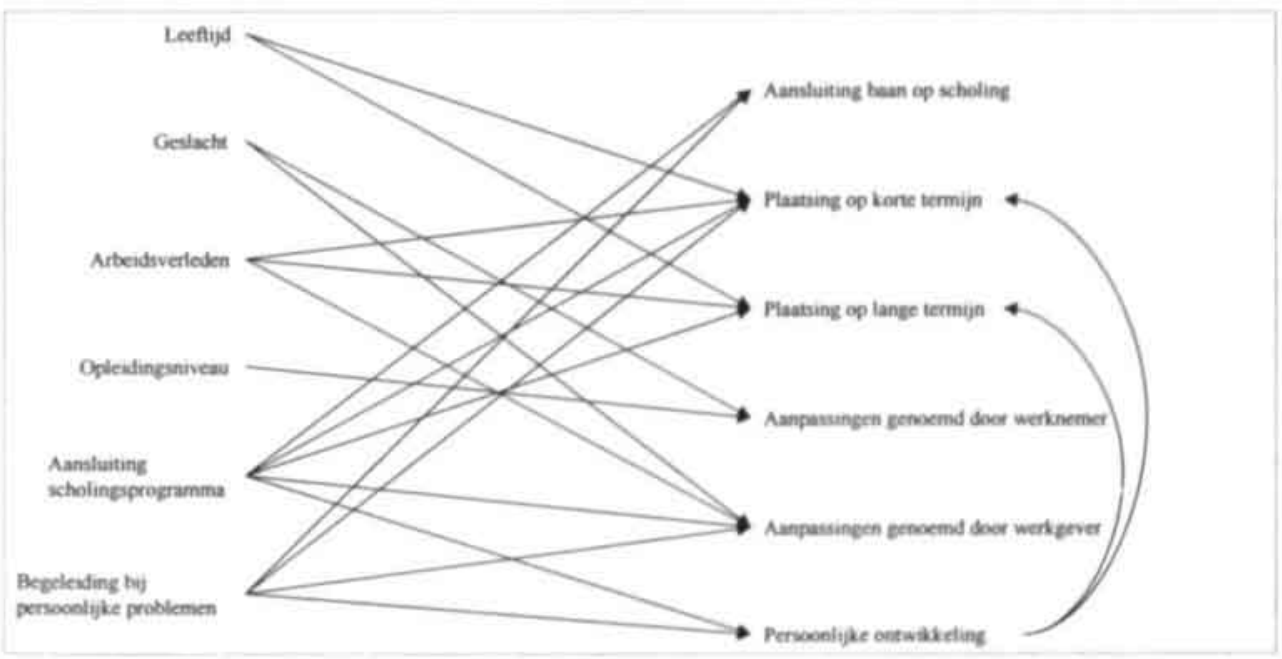

Figuur 6.4 Relatie tussen de onafhankelijke persoonsgebonden en interventiegebonden factoren en de afhankelijke participatie factoren 
De mate waarin het scholingsprogramma en de begeleiding bij persoonlijke problemen aansluiten op de persoonlijke behoeften en capaciteiten van de oud-cursisten blijken het meest verklarend voor de mate van participatie, uitgedrukt in een positiever oordeel over de persoonlijke ontwikkeling en een grotere kans op plaatsing op de korte en op de lange termijn. Tenslotte blijken op centrumniveau slechts geringe verschillen te bestaan in de mate waarin de gemeten variabelen bijdragen aan en verklarend zijn voor de mate van participatie. Dit wijst dus op een generiek effect van (langdurige) scholingsprogramma's. 


\title{
7 DISCUSSIE
}

\author{
Wat iemand menselijk maakt is juist het feit dat hij deel uitmaakt van anderen, \\ deel uitmaakt van het leven in al zijn aspecten. \\ Bestaan betekent .... participeren (Desmond Tutu)
}

\subsection{INLEIDING}

In dit hoofdstuk worden de resultaten van het onderzoek, zoals gepresenteerd in de hoofdstukken 4,5 en 6 , bediscussicerd. In eerste instantie worden de voor dit onderzoek geformuleerde vraagstellingen beantwoord (7.2). Vervolgens wordt een nadere beschouwing gegeven van de verzamelde gegevens en de wijze waarop het onderzoek is uitgevoerd (paragraaf 7.3). Tot slot wordt in paragraaf 7.4 een beschouwing gegeven van de beleidsmatige relevantie van de hier gepresenteerde resultaten.

\subsection{BEANTWOORDING ONDERZOEKSVRAGEN}

Personen met een volledige arbeidsongeschiktheidsuitkering, die minimaal twee jaar uit het arbeidsproces zijn en die een beroepsgericht scholingsprogramma hebben doorlopen, hebben een grotere kans op reïntegratie dan personen in een soortgelijke situatie die zonder een beroepsgericht scholingsprogramma op zoek zijn naar werk. Daarmee is de centrale vraagstelling uit de eerste paragraaf kort edoch duidelijk beantwoord. De beantwoording van deze vraagstelling vereist echter meer nuancering, hetgeen plaatsvindt aan de hand van de in paragraaf 2.7 geformuleerde onderzoeksvragen.

1. Wat zijn de kenmerken van de cursistenpopulatie, i.c. de persoonsgebonden factoren?

De cursistenpopulatie bestaat voor driekwart uit mannen. De gemiddelde leeftijd van de cursisten is 28 jaar. Zij hebben een gemiddeld laag opleidingsniveau, zijn langdurig uit het arbeidsproces dan wel hebben nog niet eerder gewerkt. Het merendeel van de cursisten heeft, alvorens te starten met het scholingsprogramma sinds langere tijd geen onderwijs gevolgd. Aandoeningen van het bewegingsapparaat, hersenletsels, blind- of 
slechtziendheid, psychische aandoeningen of neurologische aandoeningen komen relatief het meest voor in de cursistenpopulatie. De cursisten ervaren beperkingen in het lopen/staan, arm- en/of handgebruik of zij ervaren visusbeperkingen. Alle cursisten zijn volledig arbeidsongeschikt verklaard. Hiermee vormt de onderzoeksgroep een populatie die, zoals blijkt uit de literatuur, in beginsel qua leeftijd, opleidingsniveau, arbeidsverleden, periode van uitval uit het arbeidsproces en medische problematiek weinig tot geen kans heeft op succesvolle reïntegratie.

2. Hoe wordt het scholingsprogramma zoals toegepast door de REAscholingscentra, vormgegeven?

De scholingsprogramma's hanteren een uitgebreide assessment, waarin de mogelijkheden, capaciteiten en interesses van de cursist worden onderzocht. Vervolgens staat binnen de vaktheoretische component van het scholingsprogramma, een individuele benadering centraal, hetgeen tot uiting komt in modulaire werkvormen, waarbij niet alleen vaktechnische vaardigheden, maar ook beroepsgerichte, sociale en communicatieve vaardigheden onderdeel uitmaken van het programma. Het ondersteunings- en begeleidingsgedeelte omvat een diversiteit aan voornamelijk individuele begeleidingsvormen gericht op de persoonlijke ontwikkeling van de cursist en waar nodig additioneel aan de vaktheoretische inhoud van het scholingsprogramma. $\mathrm{Na}$ succesvolle afronding van het scholingsprogramma worden veelal indirecte bemiddelingsactiviteiten ondernomen, teneinde de cursist te ondersteunen in het zelfstandig vinden van een baan in de gekozen vakrichting.

Op basis van een toetsing aan de in de literatuur genoemde voorwaarden en criteria voor succesvolle scholingsprogramma's blijkt dat de in de REA-centra gehanteerde scholingsprogramma's in hoge mate voldoen aan deze voorwaarden en criteria.

3. In hoeverre leidt het volgen van een langdurig scholingsprogramma tot succes, geconcretiseerd in een toename van de persoonlijke ontwikkeling, plaatsing op de reguliere arbeidsmarkt en succesvol functioneren in de werksituatie?

De oud-cursisten zijn van mening dat ze door het volgen van het scholingsprogramma een positieve ontwikkeling hebben doorgemaakt met betrekking tot hun zelfvertrouwen, het kunnen omgaan met hun beperkingen, hun sociale vaardigheden en hun incasseringsvermogen.

Binnen drie maanden na succesvolle afronding van het scholingsprogramma vindt $71 \%$ van de oud-cursisten een baan die grotendeels aansluit op het gevolgde scholings- 
programma, zowel qua inhoud als qua niveau. De helft van de gereīntegreerde oudcursisten vindt deze baan door het solliciteren op reguliere advertenties of open sollicitaties. Oud-cursisten komen deels terecht in de dienstverlenende sector, deels bij productie/productieverwerkende bedrijven. De helft van de bedrijven behoort tot de grotere bedrijven ( $>100$ werknemers), de overige gereïntegreerde werknemers zijn werkzaam bij kleine of middelgrote bedrijven.

Volgens werkgevers zijn de oud-cursisten aangenomen vanwege hun vakmatige vaardigheden en/of hun persoonlijkheid. Bij een kwart van de werkgevers speelde bij de aanname het bedrijfsbeleid met betrekking tot arbeidsgehandicapten een rol. Vrijwel alle werkgevers zijn bij aanname op de hoogte van mogelijke beperkingen en de hierbij behorende consequenties. Ondanks deze kennis heeft slechts een relatief klein gedeelte van de werkgevers gebruik gemaakt van bestaande wettelijke regelingen en instrumenten ten behoeve van reintegratie, omdat ze merendeels niet op de hoogte zijn van de regelingen, de noodzaak om gebruik te maken van subsidies niet aanwezig is of omdat het regelen ervan een te grote administratieve belasting vormt.

Minder dan de helft van de oud-cursisten heeft aanpassingen in de werksituatie nodig $(44 \%)$. Het betreft aanpassingen van de werkplek, aanpassingen van het takenpakket, aanpassingen van de werktijden en extra ondersteuning en begeleiding van collega's en leidinggevenden.

Op de lange termijn, gemiddeld vijf jaar na afronding van een scholingsprogramma, is $75 \%$ van de oud-cursisten aan het werk. Het aantal aanpassingen dat nodig is, is gedaald naar $40 \%$. Volgens de helft van de werkgevers functioneren de gereîntegreerde werknemers op gelijk niveau in vergelijking met collega's die hetzelfde of vergelijkbaar werk verrichten en geen beperkingen hebben. Een kwart van de werkgevers geeft aan dat de gereïntegreerde werknemers op een hoger niveau functioneren. In deze vergelijking is qua vakinhoudelijke aspecten zowel de algemene arbeidsproductiviteit meegenomen als meer specifiek de aanwezige vakkennis, vaktechnische vaardigheden en werkhouding. Bij de vergelijking is eveneens gekeken naar de sociale vaardigheden van de gereintegreerde werknemer en het verzuimgedrag. De aanstelling van de gereïntegreerde werknemer heeft volgens de helft van de werkgevers geen invloed gehad op de werksfeer, daarentegen vindt bijna de helft van de werkgevers dat de komst van deze werknemer de sfeer in positieve zin heeft beïnvloed, hetgeen blijkt uit een betere werksfeer en meer respect en begrip voor elkaar.

Tenslotte blijkt op de lange termijn $51 \%$ van de totale populatie geen enkele vorm van uitkering meer te hebben, dit geldt voor $66 \%$ van de werkenden. Een derde deel van de 
werkenden heeft nog een uitkering die gemiddeld $32 \%$ van het totale inkomen beslaat. $\mathrm{Na}$ ongeveer zes jaar blijken naar schatting, de besparingen aan uitkeringen overeen te komen met de kosten van het scholingsprogramma. De oud-cursisten zijn op het breakeven point gemiddeld 36 jaar en in potentie nog een groot aantal jaren actief participerend op de arbeidsmarkt.

Opvallend is dat de diverse centra, die op verschillende wijze hun scholingsprogramma's vormgeven, toch, ondanks lichte accentverschillen, vergelijkbare resultaten opleveren. Bovendien zijn de populaties cursisten qua beperkingen en capaciteiten over de centra sterk uiteenlopend. Dit impliceert dat onafhankelijk van individuele verschillen en verschillen tussen centra de effecten van langdurige scholingsprogramma's op reïntegratie effectief kunnen worden genoemd.

4. In welke mate blijken persoonsgebonden factoren bij te dragen aan het resultaat van het scholingsprogramma, zijnde een toename in de persoonlijke ontwikkeling, plaatsing op de reguliere arbeidsmarkt en succesvol functioneren in de werksituatie?

Oudere cursisten hebben tijdens het scholingsprogramma meer sociale vaardigheden ontwikkeld dan jongere cursisten. Cursisten met een arbeidsverleden kunnen, in vergelijking met cursisten zonder arbeidsverleden, door het volgen van het scholingsprogramma nu beter omgaan met hun beperkingen dan voorheen. De overige onafhankelijke variabelen tonen geen verband met de persoonlijke ontwikkeling. Dit impliceert dat de persoonsgebonden kenmerken relatief weinig van invloed zijn op het effect van het scholingsprogramma op de persoonlijke ontwikkeling.

Persoonsgebonden factoren spelen wel een rol bij plaatsing en het aantal aanpassingen. Mannen zijn, in vergelijking met vrouwen, meer werkzaam op de lange termijn en hebben minder aanpassingen nodig. Dit geldt eveneens voor cursisten met een lager opleidingsniveau, voorafgaande aan het scholingsprogramma. Daarnaast zijn arbeidsverleden en leeftijd van invloed op de plaatsing op korte en lange termijn. Jongere cursisten hebben meer kans op werk op zowel korte als op lange termijn dan oudere cursisten. Cursisten met een arbeidsverleden hebben, in vergelijking met cursisten zonder arbeidsverleden, meer kans op werk op zowel korte als op lange termijn.

Het functioneren in de werksituatie wordt niet verklaard door een of meerdere persoonsgebonden factoren. 
5. In welke mate dragen de verschillende elementen van het scholingsprogramma, namelijk de vaktheoretische component en de begeleidings- en ondersteuningscomponent bij aan het resultaat van het scholingsprogramma, zijnde een toename in de persoonlijke ontwikkeling, plaatsing op de reguliere arbeidsmarkt en succesvol functioneren in de werksituatie?

Naarmate het scholingsprogramma, qua niveau, tempo en begeleiding meer aansluit bij de persoonlijke capaciteiten, interesses en (on)mogelijkheden van de cursisten, ervaren zij een toegenomen zelfvertrouwen, kunnen ze beter omgaan met hun beperkingen en hebben ze een groter incasseringsvermogen.

Het vinden van werk op zowel korte als lange termijn en het door de werkgever aangegeven aantal aanpassingen wordt onder meer verklaard door de aansluiting van het scholingsprogramma op de persoonlijke capaciteiten, interesses en (on)mogelijkheden. De kans op het vinden en behouden van werk stijgt, naarmate de aansluiting van het scholingsprogramma beter is. Meer specifiek wordt de kans op het vinden van werk op korte termijn en het aantal door werkgevers aangegeven aantal werkaanpassingen deels verklaard door de mate waarin tijdens het scholingsprogramma adequate begeleiding met betrekking tot persoonlijke problemen heeft plaatsgevonden. Het functioneren in de werksituatie wordt niet verklaard door factoren gerelateerd aan het scholingsprogramma.

\section{Conclusie}

Personen met een arbeidsongeschiktheidsuitkering hebben een grote kans op werk wanneer ze een beroepsgericht scholingsprogramma volgen. Wanneer cursisten jonger zijn, een arbeidsverleden hebben, het scholingsprogramma beter aansluit bij hun persoonlijke capaciteiten, interesses en (on)mogelijkheden én wanneer ze positiever oordelen over hun persoonlijke ontwikkeling, is de kans op werk op de lange termijn, i.c. blijvende arbeidsparticipatie het grootst. Het functioneren in de werksituatic wordt door andere, dan in deze studie onderzochte, factoren bepaald.

\subsection{DISCUSSIE}

De basis voor dit onderzoek vormt de totale populatie personen met een arbeidsongeschiktheidsuitkering die een langdurig (om)scholingsprogramma heeft gevolgd. In die zin is sprake van een uniek gegevensbestand aangezien daarmee de vraag in hoeverre dit onderzoek representatief is voor de gehele populatie personen die 
scholingsprogramma's volgen, niet meer relevant is. Daarnaast hebben alle, in de WAGW en de wet REA genoemde, reïntegratiecentra geparticipeerd in het onderzoek. Dit heeft het mogelijk gemaakt dat het onderzoek zowel de breedte van de individuele variantie als van de institutionele variantie (verschillende centra) omvat. Hierdoor wordt de generaliseerbaarheid van de uitspraken aanmerkelijk vergroot.

$\mathrm{Er}$ is echter een aantal praktische kanttekeningen te maken bij de wijze waarop het onderzoek heeft plaatsgevonden. Over deze kanttekeningen en de wijze waarop hiermee rekening moet worden gehouden bij het trekken van conclusies handelt de hiernavolgende discussie.

\section{HALO-effect}

Zoals in hoofdstuk 3 is beschreven, is getracht in deze studie rekening te houden met een mogelijk optredend HALO-effect (zie paragraaf 3.3).

In deze studie kan dit effect mogelijk toch zijn opgetreden bij het meten van de factoren persoonlijke ontwikkeling en plaatsing op korte en/of lange termijn. Wanneer oud-cursisten werk hebben gevonden, oordelen zij mogelijk meer positief over de bijdrage van het scholingsprogramma aan hun persoonlijke ontwikkeling. Het is dan onvoldoende duidelijk of het meer positieve oordeel wordt veroorzaakt door de baan die ze hebben verkregen of dat deze ontwikkeling autonoom heeft plaatsgevonden en de baan juist is verkregen door de toename in de persoonlijke ontwikkeling. In de werkelijkheid zal er waarschijnlijk sprake zijn van een wederkerig verband, waarbij er een wederzijdse positieve invloed is tussen de toegenomen persoonlijke ontwikkeling en het hebben en behouden van een baan. Wel blijkt dat de redenen die oud-cursisten geven voor niet-succesvolle reïntegratie, niet gerelateerd zijn aan het scholingsprogramma, maar vooral geweten worden aan de eigen (verslechterde) gezondheid.

\section{Selectie vóór de poort}

De voordracht, toestemming en financiering van de plaatsing op een van de centra is geen zaak voor de reîntegratiecentra, maar is afhankelijk van het oordeel van de hiervoor verantwoordelijken binnen de diverse uitvoeringsinstellingen. Ondanks dat weinig inzicht bestaat in de wijze waarop het selectieproces plaatsvindt, is wel duidelijk dat de bereidheid van cursisten om (opnieuw) de 'schoolbanken in te duiken', aangeeft dat de cursisten gemotiveerd zijn hun status van arbeidsongeschikte kwijt te raken. Enerzijds betekent dit dat wellicht minder gemotiveerde personen met een arbeidsongeschiktheidsuitkering eveneens voldoen aan het selectiecriterium maar door dit gebrek aan motivatie, niet bij de centra terechtkomen. Anderzijds zal verwijzing niet plaatsvinden omdat de arbeidsongeschikte volgens de uitvoeringsinstelling 
onvoldoende arbeidsmarktperspectief heeft. Vier van de vijf centra hanteren geen toelatingseisen; bij het vijfde centrum is het belangrijkste beoordelingscriterium of de cursist in staat zal zijn om, gezien zijn of haar intelligentieniveau, voor de opleiding te slagen.

Wanneer personen eenmaal een scholingsprogramma hebben afgerond, blijkt de kans op werk ten opzichte van de arbeidsongeschiktheidsstatus vooraf, aanzienlijk te zijn gestegen. Daarnaast blijkt uit de literatuur dat motivatie alleen niet voldoende is voor personen met een grote afstand tot de arbeidsmarkt om te kunnen reïntegreren, daarvoor zijn aanvullende maatregelen en/of activiteiten noodzakelijk (zie hoofdstuk 2). Voor de resultaten die in dit proefschrift worden gepresenteerd betekent dit dat door deze selectie een grotere groep dan de hier beschrevene succesvol kan relintegreren op de arbeidsmarkt, indien potentiële kandidaten over voldoende motivatie zouden beschikken of voldoende worden gemotiveerd en vervolgens in de gelegenheid worden gesteld om langdurige scholingsprogramma's te volgen.

\section{De complexiteit van de interventie}

Uit het hier gepresenteerde onderzoek blijkt dat naarmate het scholingsprogramma beter aansluit bij de persoonlijke capaciteiten, interesses en (on)mogelijkheden, er een positiever oordeel is over de persoonlijke ontwikkeling en dat de kans op het vinden van werk toeneemt. De interventie (het scholingsprogramma) zoals die is uitgevoerd, bestaat uit een groot aantal ingrediënten. Onduidelijk is welke onderdelen van dit programma verantwoordelijk kunnen worden gehouden voor de gevonden effecten. De vraag is of het vaktheoretisch gedeelte verantwoordelijk is voor zowel het plaatsingsresultaat als de toename in de persoonlijke ontwikkeling, of dat vooral de intensiteit van het programma, of de training en begeleiding bepalend zijn voor de veranderingen. Daarentegen is het eveneens mogelijk dat de verschillende effecten in combinatie met andere elementen uit het scholingsprogramma worden bereikt. Het ligt voor de hand dat plaatsing en een toename in de persoonlijke ontwikkeling het effect zijn van een veelheid van elementen binnen het scholingsprogramma. Deze interpretatie wordt gesteund door het feit dat de vijf centra, ondanks het gegeven dat de inhoud en vormgeving van de programma's nogal uiteenlopen, dezelfde positieve resultaten vertonen. De overeenkomst in de scholingsprogramma's bestaat uit het toewerken naar beroepsspecifieke vaardigheden, het versterken van de eigen sociale vaardigheden, de eigen effectiviteit en dergelijke, door middel van een intensief arbeidsreïntegratieprogramma. 


\section{Selectiebias}

In hoofdstuk 3 is de mogelijke kans op selectiebias reeds beschreven. Deze heeft betrekking op het gegeven dat uitsluitend oud-cursisten die tevreden zijn over hun arbeidsplek en hun eigen functioneren, toestemming hebben gegeven aan de onderzoeker om hun werkgever te mogen benaderen. Uit de interviews blijkt dat er geen sprake is van een uitsluitend positieve selectie. De indruk bestaat dat een aantal gereïntegreerde werknemers hun medewerking verleende om het in hun ogen disfunctioneren van hun werkgever/leidinggevende in de openbaarheid te brengen.

Samenvattend zijn er kanttekeningen geplaatst ten aanzien van de wederkerigheid van de uitkomsten, de selectie voor de poort, de complexiteit van de interventie en de mogelijke selectie die is opgetreden. Door het gebruik van verschillende bronnen en verschillende meetinstrumenten is geprobeerd om de tekortkomingen op delen van dit onderzoek zoveel mogelijk op te vangen.

\subsection{BESCHOUWING}

In de voorafgaande paragrafen 7.2 en 7.3 is antwoord gegeven op de vragen van dit onderzoek en tevens is bediscussieerd in hoeverre hierover op basis van de gebruikte gegevens conclusies mogelijk zijn. In deze laatste paragraaf wordt, in aansluiting op deze discussie, een beschouwing gegeven over de waarde die deze studie heeft met betrekking tot de terugdringing van het WAO-volume.

Ten behoeve van de studie die wordt gepresenteerd in dit proefschrift is een analysemodel opgesteld, waarbij is uitgegaan van een integrale benadering die onder meer is terug te vinden in het ICIDH-2 model. Dit laatste model is het meest recente product van een decennia lang durende discussie over de invloed van persoonsgebonden factoren en omgevingsgebonden factoren op de mate van participatie. Voorgaande modellen, i.c. het medisch model en de modellen gebaseerd op de sociale constructiegedachte, leggen dan wel een direct en uitsluitend verband tussen de aandoening van de persoon en de mate van participatie van deze persoon, dan wel een direct en uitsluitend verband tussen de omgeving (externe factoren) en de mate van participatie van de persoon. Beide gedachtegangen blijken niet overeenkomstig de werkelijkheid. De integrale benadering is in die zin niet alleen meer verklarend wanneer het gaat om het kunnen bepalen van de mate van participatie, maar biedt tevens handgrepen om de mate van participatie te beïnvloeden. Het in dit onderzoek 
gehanteerde analysemodel gaat eveneens uit van het gegeven dat diverse factoren een rol spelen bij arbeidsreïntegratie. Het betreft factoren die te maken hebben met de persoon zelf (de persoonsgebonden factoren), de wijze waarop de maatschappij personen ondersteunt, bijvoorbeeld door middel van scholingsprogramma's en de wijze waarop een arbeidspositie kan worden verkregen en behouden, onder meer door de houding van werkgevers en de gereïntegreerde werknemers.

De resultaten van dit onderzoek laten zien dat de integrale benadering een goed uitgangspunt vormt voor het bevorderen van participatie. Bij een groep personen met een grote afstand tot de arbeidsmarkt (vanwege hun status van arbeidsongeschiktheid, hun leeftijd, opleidingsniveau, arbeidsverleden en de aanwezigheid van een chronische ziekte of beperking) blijkt, dat mits hiervoor voldoende adequate maatregelen worden genomen, de kans op een toegenomen arbeidsparticipatie van mensen met een arbeidshandicap wordt versterkt. Hierbij moet worden onderkend dat een dergelijke benadering niet altijd succesvol is, in een aantal gevallen zullen persoonsgebonden factoren een reïntegratie belemmeren.

In het algemeen laat dit onderzoek zien dat adequate maatregelen conform het ICIDH2 model, te weten een op maat gesneden scholingsprogramma, een sociale omgeving die de persoon in staat stelt een dergelijk programma te volgen en de bereidwilligheid van werkgevers om de noodzakelijke aanpassingen te regelen, hebben geleid tot het verkrijgen en behouden van betaald werk en tegelijkertijd hebben geleid tot een toegenomen zelfvertrouwen, tot het beter kunnen omgaan met de aanwezige chronische ziekte of beperkingen, tot betere sociale vaardigheden en tot een groter incasseringsvermogen.

Wanneer de hier beschreven bevindingen worden vertaald naar beleid, heeft dit met name betrekking op beleid gericht op personen met een grote afstand tot de arbeidsmarkt. Door de recent ingevoerde privatisering van de reīntegratie-activiteiten wordt getracht de instroom in de WAO te beperken. De personen waarop deze activiteiten betrekking hebben, behoren echter voor het overgrote deel niet tot de doelgroep zoals beschreven in dit onderzoek. In die zin hebben de resultaten van dit onderzoek alleen betrekking op die doelgroep, die tot op heden, bijna volledig buiten de reïntegratie-aandacht van de uitvoeringsinstellingen valt, namelijk de als 'fase-4' geclassificeerde cliënten', In de aanbestedingsprocedure, zoals die heeft plaatsgevonden in de tweede helft van het jaar 2000 is deze groep niet of nauwelijks meegenomen. Niet alleen zijn de nieuwe fase-4 cliënten niet meegenomen, ook de fase-3/4 cliënten uit de huidige WAO-populatie worden veelal buiten de aanbestedingsprocedure gehouden. Concreet betekent dit dat nauwelijks aandacht wordt besteed aan een groep waarvan op basis van dit onderzoek blijkt dat blijvende 
arbeidsreïntegratie tot de reêle mogelijkheden behoort. Uit de kosten-baten analyse blijkt bovendien dat na 'terugbetaling' van de kosten, personen nog jarenlang actief kunnen participeren en daarmee een positieve bijdrage kunnen leveren aan het nationaal bruto product.

Zoals de aanbestedingsprocedure heeft plaatsgevonden voor de 'meest aantrekkelijke arbeidsgehandicapten', zo zou een gelijksoortige procedure kunnen plaatsvinden voor de doelgroep zoals beschreven in dit onderzoek. Hierbij moeten wel enige kanttekeningen worden geplaatst om te voorkomen dat deze 'laatste mogelijkheid' niet succesvol wordt afgesloten. Opvallend namelijk in de huidige ontwikkelingen is dat de toekenning c.q. toestemming voor een reïntegratietraject afhangt van de professional bij de centrale uitvoeringsinstelling (UWV). De professional is in de besluitvorming hieromtrent afhankelijk van en dient rekening te houden met onder meer bestaande wet- en regelgeving, beschikbare instrumenten en middelen en arbeidsmarktgerelateerde aspecten. De arbeidsgehandicapte heeft niet alleen geen inspraak in het reïntegratiebedrijf dat het reïntegratietraject gaat uitvoeren, tevens is geen inspraak in de toekenning van het gevraagde traject. Wanneer het door de professional goedgekeurde traject niet leidt tot succes in de zin van het vinden van betaald werk, zal de professional hier niet meer op worden aangesproken. De verantwoordelijkheid daarvoor wordt grotendeels bij de arbeidsgehandicapte zelf gelegd.

Het overlaten aan de professional van 'datgene wat goed is voor de persoon' doet uitermate sterk denken aan de gedachtegang achter het medisch model. Juist van dit model is inmiddels voldoende bekend om te stellen dat het niet werkt. Met name door de overbenadrukking van de rol van de professional, waarbij evenals bij het medisch model, het individu een ondergeschikte rol speelt, lijkt het op deze wijze uitvoeren van de aanbestedingsprocedure gedoemd te mislukken.

Daarnaast wordt in de huidige aanbestedingsprocedure uitgegaan van een plaatsingssucces van (minimaal) $35 \%$. Onduidelijk is wat vervolgens gaat gebeuren met de groep die niet wordt geplaatst, de overige $65 \%$. De mogelijkheid dat een dergelijk laag succespercentage eerder zal leiden tot een toename dan tot een afname van de WAO-populatie is reëel aanwezig. Het plaatsingssucces van $35 \%$ heeft betrekking op een plaatsing van zes maanden, hetgeen inhoudt dat de reïntegratie activiteiten zullen worden gericht op het plaatsingsproces zelf en niet worden gericht op duurzame plaatsing. Tenslotte wordt de verantwoordelijkheid voor plaatsing bij de reïntegratiebedrijven gelegd. Door zich contractueel te binden aan het behalen van een bepaald plaatsingspercentage, committeren deze bedrijven zich aan het ondernemen van activiteiten teneinde plaatsing te bewerkstelligen. De verantwoordelijkheid van de individuele arbeidsgehandicapte voor zijn/haar eigen reìntegratie wordt in deze niet 
meegenomen, zij worden geacht deel te nemen aan de voor hen ontwikkelde reïntegratie activiteiten. Wanneer ook van de individuele arbeidsgehandicapte commitment wordt gevraagd in de vorm van een contractueel vastleggen van de verplichting om zich in te spannen om te (re)integreren op de arbeidsmarkt, wordt daarmee de verantwoordelijkheid zowel bij het individu als bij het reïntegratiebedrijf gelegd. Het vastleggen van de verantwoordelijkheid van het individu dient te worden gezien als een positieve incentive en niet te worden ingezet om het individu te 'straffen' bij het niet behalen van het gestelde doel. Het niet behalen van de gestelde doelen is namelijk binnen de integrale modellen het negatieve resultaat van een interactie tussen het individu en zijn/haar omgeving. Het individu exclusief verantwoordelijk te laten zijn voor het eindresultaat, zoals dit gebeurt binnen het medisch model, blijkt in de praktijk een averechts effect te hebben op het reïntegratiesucces.

Op basis van de in dit onderzoek gepresenteerde resultaten en de hiervoor gekozen theoretische uitgangspunten dient een mogelijke aanbestedingsprocedure voor de doelgroep fase- 4 arbeidsgehandicapten te voldoen aan een aantal basisvoorwaarden. Allereerst dient te worden uitgegaan van de positie waarin deze 'fase-4 arbeidsgehandicapten' verkeren. Dit betekent concreet dat bij de aanbesteding rekening moet worden gehouden met de persoonlijke wensen van de arbeidsgehandicapte; deze moeten worden verkend en ontwikkeld. Teneinde te voorkomen dat deze 'laatste mogelijkheid' alsnog dreigt te mislukken, dient van de reïntegratiebedrijven een beduidend hoger plaatsingspercentage te worden gevraagd. Vervolgens moet zowel het reïntegratiebedrijf als de arbeidsgehandicapte zich contractueel committeren aan het reïntegratietraject. Tenslotte dient het arbeidstoeleidingstraject volledig op de persoon te worden afgestemd (maatwerk) en gericht te zijn op duurzame plaatsing, zonder restrictie van inzet en middelen. Volledige afstemming kan alleen wanneer de daartoe opgeleide deskundigen in staat worden gesteld om de capaciteiten, interesses en (on)mogelijkheden van de arbeidsgehandicapte in kaart te brengen en het toeleidingstraject eveneens wordt geredigeerd door deskundigen (hiertoe behoort ook de arbeidsgehandicapte zelf). Voor dergelijke aanbestedingsprocedures dienen andere, dan de huidige financieringsstructuren te worden ontwikkeld, aangezien door de grote afstand tot de arbeidsmarkt van de doelgroep dergelijke trajecten langdurig en intensief kunnen zijn en gepaard kunnen gaan met aanzienlijk hogere kosten dan de arbeidstoeleidingstrajecten voor de huidige aanbestedingspopulatie.

De in dit proefschrift beschreven populatie kenmerkt zich door een hoge motivatic om (opnieuw) te participeren op de arbeidsmarkt. In de sociale psychologie wordt de groep 
die hoog gemotiveerd is om bepaalde activiteiten uit te voeren, gezien als verblijvende in het laatste stadium van een gedragveranderingsproces (ready to action). Het gehele proces bestaat uit vijf verschillende stadia, startende bij het stadium waarin personen nog niet eens nadenken over een verandering van hun gedrag (precontemplator). Door middel van het vergroten van de kennis omtrent de voor- en nadelen van een bepaald gedrag, kunnen personen in een volgend stadium terecht komen, waarin ze gaan nadenken of ze mogêlijkerwijs hun gedrag willen veranderen (contemplator). Onder meer door het laten zien van goede resultaten van een bepaald gedrag (modelling) kunnen personen bereid zijn hun gedrag inderdaad te gaan veranderen (motivation to comply). Tenslotte wordt door het aanbieden van concrete handgrepen, instrumenten en middelen de gelegenheid gecreěerd het nieuwe, gewenste gedrag daadwerkelijk te gaan uitvoeren (ready to action en action). Alleen wanneer in het juiste stadium de juiste middelen worden ingezet, is de kans op gedragsverandering het grootst. Deze afgeleide versie van het stages of change model (Velicer, Rossi, Prochaska \& Diclemente, 1996) is volledig toe te passen op de verschillende stadia waarin personen verkeren die momenteel tot de WAO-populatie behoren. Wat we met name van dit model kunnen leren is dat voor deze populatie de juiste instrumenten dienen te worden ingezet voor het specifieke stadium waarin de arbeidsongeschikt verklaarde personen verkeren. Aan de groep hooggemotiveerden zullen op maat gesneden reïntegratieprogramma's moeten worden aangeboden, ongeacht de ernst van de problematiek die speelt. De resultaten van het hier gepresenteerde onderzoek laten zien dat ook voor gemotiveerde personen met een zeer grote afstand tot de arbeidsmarkt succesvolle reīntegratie mogelijk is, mits wordt voldaan aan de basiseisen met betrekking tot maatwerk. Voor personen die (nog) niet in dit stadium verkeren zullen programma's moeten worden ontwikkeld, gericht op het stadium waarin ze verkeren teneinde hen te ondersteunen bij het doorlopen van de eerder geschetste veranderingsstadia.

Om succesvol een reìntegratiebeleid te ontwikkelen is het dus van belang een structuur te creëren waarin eenieder die beperkt is, recht heeft op maatschappelijke ondersteuning om op die wijze zijn of haar eigen autonomie tot gelding te laten brengen. Daartoe dient, voor zover de aandacht uitgaat naar personen met een arbeidshandicap, met name het beleid gericht te zijn op het bevorderen van de attitude van de persoon om hem of haar te helpen bij het bouwen aan een eigen toekomst en vervolgens alle middelen te bieden die daarvoor nodig zijn. Het betekent de facto dat personen met een arbeidshandicap een individueel afdwingbaar recht dienen te krijgen op adequate hulpmiddelen en voorzieningen. Uit het in dit proefschrift gepresenteerde onderzoek blijkt dat dit in ieder geval kan door het aanbieden van adequate 
scholingsprogramma's, waardoor personen werk kunnen vinden, waarbij de aanwezige chronische ziekte of beperking niet of nauwelijks meer leidt tot problemen in de werksituatie. Het regelen van de voor het adequaat uitvoeren van de werkzaamheden benodigde aanpassingen vormt hiervoor een integraal onderdeel.

Maatschappelijk gezien zal deze aanpak enerzijds leiden tot een toegenomen participatie van alle personen, al dan niet met een beperking, en anderzijds betekent het tegelijkertijd dat de maatschappelijke 'handicap-gerelateerde' kosten aanzienlijk kunnen worden beperkt. In dit geval kan er dus uitsluitend sprake zijn van een situatie waarbij er zowel op individueel als op maatschappelijk niveau winst kan worden behaald, namelijk door het vergroten van de autonomie van personen met een arbeidshandicap. 



\section{SAMENVATTING}

De toenemende groei van de WAO-populatie heeft in de afgelopen decennia geleid tot velerlei matregelen die tot nu toe als onvoldoende effectief kunnen worden beschouwd. De beleidsmaatregelen blijken voornamelijk op het systeem te zijn gericht en blijken onvoldoende in staat om het gedrag van werkgevers en werknemers met betrekking tot het proces van reïntegratie te beinvloeden. Derhalve lijkt het interessant om de aandacht te focussen op maatregelen die rechtstreeks betrekking hebben op de persoon die vanwege een ziekte of aandoening arbeidsongeschikt is verklaard en zijn/haar weg naar de arbeidsmarkt moet (terug)vinden. De kans op succesvolle reĩntegratie wordt onder meer positief beïnvloed wanneer (om)scholingsprogramma's worden gevolgd, waarbij aandacht wordt gegeven aan het trainen van persoonlijke, sociale en werkgerelateerde vaardigheden. Tot op heden is het succes van dergelijke (om)scholingsprogramma's niet systematisch onderzocht in Nederland. In dit proefschrift worden de resultaten weergegeven van een studie naar het succes van het volgen van langdurige (om)scholingstrajecten door personen die vanwege een ziekte of aandoening een arbeidsongeschiktheiduitkering ontvangen en op die wijze hun kans op de reguliere arbeidsmarkt te vergroten. De totale groep personen in Nederland die gedurende een bepaalde periode een langdurig (om)scholingstraject heeft doorlopen bij een van de vijf hiertoe aangewezen reīntegratiecentra, heeft hierbij als onderzoeksgroepspopulatie gediend. Het betreft personen die volledig arbeidsongeschikt zijn verklaard. De populatie bestaat voor driekwart uit mannen. De gemiddelde leeftijd van de cursisten is 28 jaar (bij instroom). De cursisten hebben een gemiddeld laag opleidingsniveau, zijn langdurig uit het arbeidsproces of hebben nog niet cerder gewerkt. Het merendeel heeft, alvorens te starten met het scholingsprogramma, sinds langere tijd geen onderwijs gevolgd. De cursisten hebben aandoeningen van het bewegingsapparaat, hebben hersenletsel (al dan niet aangeboren), zijn blind of slechtziend of hebben psychische aandoeningen. $\mathrm{Zij}$ ervaren beperkingen in het lopen/staan, arm- en/of handgebruik of ervaren visusbeperkingen. Bij een derde deel van de populatie is sprake van een meervoudige, complexe problematiek.

Naast cursisten zijn professionals, die verantwoordelijk zijn voor de scholingsprogramma's, in dit onderzoek betrokken. Ook werkgevers, die gereintegreerde werknemers die een scholingsprogramma hebben gevolgd in dienst hebben genomen, hebben aan dit onderzoek deelgenomen.

In dit onderzoek wordt een antwoord gezocht op de vraag in hoeverre een specifieke vorm van interventie, namelijk een scholingstraject, succesvol is, c.q. bijdraagt aan een 
vergroting van de uitstroom uit de WAO. Enerzijds is dus sprake van een beschrijvend onderzoek, anderzijds wordt nagegaan welke factoren verklarend zijn voor succes. Het beschrijvende deel van het onderzoek heeft betrekking op het in kaart brengen van de persoonsgebonden variabelen, de vormgeving van het reïntegratietraject, het plaatsingsproces en het functioneren in de werksituatie. Het verklarende deel heeft betrekking op het onderzoeken van de verbanden tussen persoonlijke factoren, externe factoren en de mate van participatie. De gegevens omtrent persoonsgebonden factoren zijn verzameld door middel van een dossierstudie. Gegevens omtrent de vormgeving van het reïntegratietraject zijn op vier verschillende wijzen verzameld, namelijk een documentenstudie, schriftelijke vragenlijsten, interviews (individuele diepte-interviews en focusgroep-interviews) en een telefonische survey. Gegevens omtrent het plaatsingsproces zijn verzameld door middel van een telefonische survey. Tot slot zijn gegevens omtrent bedrijfsgebonden factoren en het functioneren in de werksituatie verzameld door middel van gestructureerde diepte-interviews. Het betreft een crosssectioneel onderzoek, waarbij gedeeltelijk gebruik wordt gemaakt van retrospectie.

De reïntegratiecentra hanteren een uitgebreide assessment, waarin zowel aandacht voor de psychische en fysieke belastbaarheid, alsmede psychodiagnostiek, motorische vaardigheden en beroepsgerichte oriëntatie. Binnen de vaktheoretische component staat een individuele benadering centraal, hetgeen tot uiting komt in de modulaire werkvormen. Er wordt relatief veel aandacht besteed aan de praktijkcomponent waarbij niet alleen vaktechnische vaardigheden maar ook beroepsgerichte sociale en communicatieve vaardigheden onderdeel uitmaken van het programma. Het ondersteunings- en begeleidingsgedeelte omvat een diversiteit aan (voornamelijk individuele) begeleidingsvormen, gericht op de persoonlijke ontwikkeling van de cursist en - waar nodig - additioneel aan de vaktheoretische inhoud van het scholingsprogramma. Tenslotte is voornamelijk sprake van indirecte bemiddelingsactiviteiten, teneinde de cursist te ondersteunen in het zelfstandig vinden van een baan in de gekozen vakrichting. Nazorg vindt vrijwel alleen vraaggericht plaats.

De scholingsprogramma's voldoen in hoge mate aan de voorwaarden voor succesvolle scholingsprogramma's, zoals deze in de literatuur worden beschreven.

De oud-cursisten zijn van mening dat ze door het volgen van het scholingsprogramma een positieve ontwikkeling hebben doorgemaakt met betrekking tot hun zelfvertrouwen, het kunnen omgaan met hun beperkingen, hun sociale vaardigheden en hun incasseringsvermogen. 
Binnen drie maanden na succesvolle afronding van het scholingsprogramma vindt $71 \%$ van de oud-cursisten een baan die grotendeels aansluit op het gevolgde scholingsprogramma, zowel qua inhoud als qua niveau. De helft van de succesvol gereïntegreerden vindt deze baan door het solliciteren op reguliere advertenties of open sollicitaties. Oud-cursisten komen deels terecht in de dienstverlenende sector, deels bij productie/productieverwerkende bedrijven. De helft van de bedrijven behoort tot de grotere bedrijven ( $>100$ werknemers), de overige gereìntegreerde werknemers zijn werkzaam bij kleine of middelgrote bedrijven.

Volgens werkgevers zijn de oud-cursisten aangenomen vanwege hun vakmatige vaardigheden en/of hun persoonlijkheid. Bij een kwart van de werkgevers speelde het gevoerde handicapbeleid een rol. Vrijwel alle werkgevers zijn bij aanname op de hoogte van mogelijke beperkingen en de hierbij behorende consequenties. Ondanks deze kennis heeft een relatief klein gedeelte van de werkgevers gebruik gemaakt van bestaande wettelijke regelingen en instrumenten ten behoeve van reïntegratie, omdat ze merendeels niet op de hoogte zijn van de regelingen, het niet nodig is of omdat het regelen ervan een te grote administratieve belasting vormt. Minder dan de helft van de oud-cursisten heeft aanpassingen in de werksituatie nodig (44\%). Het betreft aanpassingen van de werkplek, aanpassingen van het takenpakket, aanpassingen van de werktijden en ondersteuning en begeleiding van collega's en leidinggevenden.

Op de lange termijn, gedefinieerd als gemiddeld vijf jaar na afronding van een scholingsprogramma, is $75 \%$ van de oud-cursisten aan het werk. Het aantal aanpassingen dat nodig is, is gedaald naar $40 \%$. Volgens de helft van de werkgevers functioneren de gereïntegreerde werknemers op gelijk niveau in vergelijking met collega's die overeenkomstig werk verrichten en geen beperkingen hebben. Een kwart van de werkgevers geeft aan dat de gereïntegreerde werknemers op een hoger niveau functioneren. In deze vergelijking is qua vakinhoudelijke aspecten zowel de algemene arbeidsproductiviteit meegenomen als meer specifiek de aanwezige vakkennis, vaktechnische vaardigheden en werkhouding. Bij de vergelijking is eveneens gekeken naar de sociale vaardigheden van de gereïntegreerde werknemer en het verzuimgedrag. De aanstelling van de gereintegreerde werknemer heeft volgens de helft van de werkgevers geen invloed gehad op de werksfeer, daarentegen vinden vrijwel alle overige werkgevers dat de komst van deze werknemer de sfeer in positieve zin heeft beïnvloed, hetgeen blijkt uit een betere werksfeer en meer respect en begrip voor elkaar.

Tenslotte blijkt op de lange termijn $51 \%$ van de totale populatie geen enkele vorm van uitkering meer te hebben, dit geldt voor $66 \%$ van de werkenden. Een derde deel van de 
werkenden heeft nog een uitkering die gemiddeld $32 \%$ van het totale inkomen beslaat. $\mathrm{Na}$ ongeveer zes jaar blijken naar schatting, de besparingen aan uitkeringen overeen te komen met de integrale kosten van het scholingsprogramma. De oud-cursisten zijn op het break-even point gemiddeld 36 jaar en in potentie nog een groot aantal jaren actief participerend op de arbeidsmarkt.

Oudere cursisten hebben tijdens het scholingsprogramma meer sociale vaardigheden ontwikkeld dan jongere cursisten. Cursisten met een arbeidsverleden kunnen, in vergelijking met cursisten zonder arbeidsverleden, door het volgen van het scholingsprogramma nu beter omgaan met hun beperkingen dan voorheen. De overige onafhankelijke variabelen tonen geen verband met de persoonlijke ontwikkeling, hetgeen impliceert dat de persoonsgebonden kenmerken relatief weinig van invloed zijn op het effect van het scholingsprogramma op de persoonlijke ontwikkeling. Daarnaast blijkt geen van de persoonsgebonden kenmerken verklarend te zijn voor de persoonlijke ontwikkeling. Persoonsgebonden factoren spelen wel een rol bij plaatsing en het aantal aanpassingen. Mannen zijn, in vergelijking met vrouwen, meer werkzaam op de lange termijn en hebben minder aanpassingen nodig. Dit geldt eveneens voor cursisten met een lager opleidingsniveau, voorafgaande aan het scholingsprogramma. Plaatsing op korte en lange termijn wordt deels verklaard door arbeidsverleden en leeftijd. Jongere cursisten hebben meer kans op werk op zowel korte als op lange termijn dan oudere cursisten. Cursisten met een arbeidsverleden hebben. in vergelijking met cursisten zonder arbeidsverleden, meer kans op werk op zowel korte als op lange termijn.

Het functioneren in de werksituatie wordt niet verklaard door een of meerdere persoonsgebonden factoren.

Naarmate cursisten een meer positief oordeel hebben over het niveau en het tempo van - en de begeleiding tijdens het scholingsprogramma, ervaren ze een toegenomen zelfvertrouwen, kunnen ze beter omgaan met hun beperkingen, hebben ze een groter incasseringsvermogen en functioneren ze beter op de arbeidsmarkt.

Het vinden van werk op zowel korte als lange termijn en het door de werkgever aangegeven aantal aanpassingen wordt onder meer verklaard door de waardering voor het onderwijs in totaal. Meer specifiek wordt het vinden van werk op korte termijn en het aantal door werkgevers aangegeven aantal werkaanpassingen deels verklaard door de begeleiding bij persoonlijke problemen tijdens het scholingsprogramma. Het functioneren in de werksituatie wordt niet verklaard door factoren gerelateerd aan het scholingsprogramma. 
Aangezien alleen gegevens bekend zijn over bedrijfsgrootte en bedrijfssector in relatie tot gereintegreerde werknemers is het niet mogelijk een relatie te leggen met de variabelen binnen de factor plaatsing. Tussen bedrijfsgrootte en bedrijfssector enerzijds en variabelen binnen de factor functioneren in de werksituatie anderzijds bestaat geen samenhang.

Kanttekeningen die kunnen worden geplaatst bij deze studie hebben betrekking op een mogelijk HALO-effect, selectiviteit van de onderzoekspopulaties, het onderzoeksdesign, ontbrekende gegevens en de complexiteit van de interventie. Door gebruik te maken van een diversiteit aan bronnen en meetinstrumenten is getracht de tekortkomingen van dit onderzoek zoveel mogelijk te beperken. De conclusies die op basis van dit onderzoek zijn getrokken, kunnen dan ook als terechte conclusies worden gezien.

Uit dit onderzoek kan worden geconcludeerd dat personen met een arbeidsongeschiktheidsuitkering een grote kans op werk hebben wanneer ze een beroepsgericht scholingsprogramma volgen.

Wanneer cursisten jonger zijn, een arbeidsverleden hebben, het scholingsprogramma beter aansluit bij hun persoonlijke capaciteiten, interesses en (on)mogelijkheden én wanneer ze een positiever oordeel hebben over hun persoonlijke ontwikkeling, is de kans op blijvende arbeidsparticipatie het grootst.

Voor toekomstig beleid betekent dit dat een aangepaste vorm van de huidige aanbestedingsprocedures zou kunnen worden ingezet voor personen met een grote afstand tot de arbeidsmarkt, de 'fase- 4 arbeidsgehandicapten'. Concreet houdt dit in dat bij de aanbesteding rekening moet worden gehouden met persoonlijke wensen van de arbeidsgehandicapte; deze moeten worden verkend en ontwikkeld. Daarnaast zal van de reĭntegratiebedrijven een hoger plaatsingspercentage moeten worden gevraagd, teneinde te voorkomen dat alsnog een 'restgroep' ontstaat. Vervolgens dient zowel het reïntegratiebedrijf als de arbeidsgehandicapte zich contractueel te committeren aan het reïntegratietraject. Tenslotte is maatwerk noodzakelijk, gericht op duurzame plaatsing en zonder restrictie van inzet en middelen.

Het stages of change model kan dienen als basis voor reïntegratiebeleid voor personen met een grote afstand tot de arbeidsmarkt. Aan de groep hooggemotiveerden zullen op maat gesneden reîntegratie programma's moeten worden aangeboden, ongeacht de ernst van de problematuek die speelt. Voor personen die (nog) niet in deze fase verkeren zullen programma's moeten worden ontwikkeld, gericht op de fase waarin ze 
verkeren. Centraal staat dat een structuur wordt gecreëerd waarin eenieder die beperkt is, recht heeft op maatschappelijke ondersteuning om op die wijze zijn of haar eigen autonomie tot gelding te laten brengen.

Maatschappelijk gezien zal dit enerzijds leiden tot een toenemende participatie van alle personen, al dan niet met een beperking, en anderzijds betekent het tegelijkertijd dat de maatschappelijke handicap-gerelateerde kosten aanzienlijk kunnen worden beperkt. In dit geval kan er dus uitsluitend sprake zijn van een situatie waarbij er zowel op individueel als op maatschappelijk niveau winst kan worden behaald, namelijk door het vergroten van de autonomie van personen met een arbeidshandicap. 


\section{SUMMARY}

Motivated by the increasing number of people receiving disability benefits (the WAO population) a great number of measures has been taken during the last few decades which can now be said to be insufficiently effective. Policy measures appear to be mainly system-oriented, lacking in power to affect the behaviour of employers and employees in relation to the process of reintegration. As a result, it may be interesting to focus the attention on those measures which bear directly on the individual who, after being declared unfit for work due to some illness or disorder, will have to make his/her way to re-enter the labour market. As the literature points out, the chances of successful rehabilitation are favourably affected if, for example, the individual follows a rehabilitation programme to train personal, social and work-related skills. Thus far, systematic studies examining the success rates of those rehabilitation programmes have been non-existent. The present thesis reports the results of a study which was designed to examine the amount of success when lengthy retraining programmes were followed by individuals who, while receiving disability benefits due to illness or disorder, experienced a wide gap between themselves and the labour market and used this venue to increase their chances at the regular labour market. The research population was the total group of people in the Netherlands who, during a specific period of time, took a long-range retraining course at one of the five appointed vocational rehabilitation centres. The individuals involved had been declared totally unfit for work. Three quarters of the sample were men. The average age of the students was 28 years (at baseline). Their average educational level was low; they had been out of work for a long time or they did not have any previous jobs. When starting the rehabilitation programme it was a long time ago that they had their last educational activities. The students had locomotive disorders or brain damage (either hereditary or acquired) or they were blind or partially sighted or they had mental disorders. They suffered from limitations in their capacities for walking/standing, the use of hands and/or arms and vision. In one third of the study population the individual problems were complex. In addition to the students, professionals responsible for the rehabilitation programmes were also included in the study. Even employers hiring rehabilitated employees who had followed a retraining programme participated in the study.

The present study was designed to examine the success of a specific type of intervention, i.e. a training programme, in helping to reduce the number of people receiving WAO benefits. Thus, on the one hand, it is a descriptive study while on the 
other hand it attempts to identify the factors that may explain the success of this approach. The descriptive part of the study refers to defining individual-related variables, the design of the rehabilitation course, the placement process and job performance. The explanatory part involves an analysis of the relationships between personal factors, external factors and amount of participation. Data on individual factors were gathered by reviewing records. Data on the rehabilitation course design were collected in four different ways: document study, written questionnaires, interviews with professionals (individual in-depth interviews and focus group interviews) and a telephone survey among previous students. The data on the placement process were collected by using a telephone survey. The data on companyrelated factors and job performance, finally, were collected by conducting standardised and in-depth interviews with employers. It is a cross-sectional study, based partly on retrospection.

The rehabilitation centres have applied extensive assessments, addressing both mental and physical capabilities as well as psychological functioning. motor skills and vocational orientation. Central to the component of technical theory is an individual approach, which is made manifest in module-based methods. A comparatively great deal of attention is paid to the practical component, where the programme not only includes specific technical skills, but also social and communication skills that are relevant to the profession. Support and guidance include a diversity of predominantly individual types of supervision aimed at promoting the student's personal development and - if necessary - supplementing specific technical details of the training programme. Mediation activities, finally, are usually indirect in order to support the students' autonomy in finding a job in the discipline of their choice. Mostly, follow-up is provided on demand only.

The training programmes highly meet the conditions of successful training schemes set out in the literature.

Former students felt that the training programme had a positive effect on their development in terms of confidence, coping with limitations, social skills and resilience.

Within three months after successful completion of the training programme $71 \%$ of the previous students found a job which, for the greater part, matched the training programme, both in substance and in level. Half of those successfully rehabilitated found their jobs by applying for regularly announced vacancies or by making 
unsolicited applications. Some of the former students found themselves a job in the service industry, others in production or processing companies. Half of the companies involved can be categorised as large businesses (over 100 employees), the remaining rehabilitated employees were employed by small and medium-sized businesses.

As the employers explained, former students were engaged because of their technicalvocational skills and/or their character. Adopted disability policies played a role with $25 \%$ of the employers. At the time of hiring, practically all employers were aware of potential limitations and associated consequences. Despite this knowledge it was a relatively small number of employers who benefited from existing legal regulations and instruments aimed at promoting rehabilitation: because most of them did not know about those regulations; because they had no need for them; or because they felt it was too much of an administrative burden to make use of them. Fewer than half of all former students needed some adjustment to be made in the work situation. It involved adaptations of the workplace, task adjustments, individually adjusted working hours or a need for support and counselling by colleagues and superiors.

Seen in a long-term perspective, $75 \%$ of all previous students has found a job within an average of five years following completion of the training programme. Half of all employers stated that rehabilitated employees performed on the same quality level as their counterparts who had similar tasks without suffering limitations. Another $25 \%$ of the employers stated that rehabilitated employees performed at higher levels. In terms of specific vocational qualities, the comparison included both general productivity and, more specifically, their professional knowledge, professional skills and attitude to work. The comparison also took into account the social skills of rehabilitated employees as well as their absenteeism. As about half of the employers explained, hiring rehabilitated employees did not affect the atmosphere at work, whereas almost all other employers felt that the arrival of those employees had a favourable effect on the work climate, which became manifest in a better atmosphere at work and greater mutual respect and understanding.

Of those who found a job, $66 \%$ proved to have stopped receiving benefits of any kind. Among those who were still receiving benefits, the benefits on average constituted $32 \%$ of their total income. After about six years benefit savings are estimated to equal the costs of the training programme. At the break-even point the former students on average were 36 years old while still being potentially active participants in the labour market for a great number of years. 
Older students tended to develop more social skills during the training programme than younger students. As a result of the training programme, students who previously used to have a job were able to cope better with their limitations than before as compared to students who never had a job. The other independent variables did not have any relationship with personal development, implying that individual characteristics had relatively little influence on the effect of the training programme on personal development. Furthermore, none of the individual characteristics appeared to explain personal development.

Individual factors played a limited role in placements and in the number of adjustments. Men had more long-term jobs while needing fewer adjustments as compared to women. The same applied to students with lower educational levels previous to the training programme.

In part, both short-term and long-term placement were explained by employment history and age. Younger students have better chances of finding either short-term or long-term jobs than older students. Students with a job history have better chances of finding either short-term or long-term jobs than students without any employment history.

Performance within the work situation is not explained by one or more individual factors.

As students have more positive views of the standards and pace of the training programme and the supervision provided therein, they feel more confident, are better able to cope with limitations, show greater resilience and perform better on the labour market.

Finding a job at short notice or after a longer period of time or the number of adjustments made as indicated by employers can be explained in part by the amount of appreciation shown for education as a whole. More specifically, finding a job at short notice and the number of adjustments made as indicated by employers are partly explained by the availability of counselling for personal problems during the training programme. Functioning within the work situation is not explained by factors related to the training programme.

Since the only data known refer to company size and industrial sector in relation to rehabilitated employees it is not possible to establish any links with variables within the placement factor. No connection existed between company size and industrial sector, on the one hand, and variables within the factor describing functioning in the work situation, on the other. 
Critical comments that can be made on this study refer to the possibility of a halo effect, the selectivity of research populations, the study design, incomplete data and the complexity of the intervention. By using a diversity of sources and measuring instruments an effort was made to reduce the inadequacies of the study as much as possible. Thus, the conclusions resulting from the study can be considered justified.

One of the conclusions that can be drawn from the study is that individuals receiving disability benefits have better chances of finding a job if they follow a vocational training programme. Their chances of finding permanent employment are greatest if students are younger, if they have some employment history, if the training programme better matches their personal capacities, interests, potential or lack of potential and if they can experience some increase in personal development.

The implications for future policy-making are that current contracting-out procedures might be employed in some customised form for those who feel themselves at a great distance from the labour market. More specifically, what it entails is that contractingout should take into account the disabled person's individual wishes. In addition, companies participating in rehabilitation schemes should apply relatively greater numbers of placements in order to avoid the emergence of yet another 'residual category'. Next, both the rehabilitation company and the disabled worker will have to commit themselves to the rehabilitation trajectory in writing. Finally, what is needed is custom-made solutions designed to achieve permanent placement without any restrictions to commitment or resources.

Customised rehabilitation programmes should be offered to those who are highly motivated, independently of the gravity of the problems involved. As for those who as yet - have not reached this phase it will be necessary to develop programmes that will deal specifically with their current phase of development. The main point is to create a structure in which anyone suffering from some limitation is entitled to receiving some form of social support that will help him/her to realise his/her individual autonomy.

Seen from a social perspective, this will lead to increased labour participation by all individuals, either with or without limitations, while at the same time resulting in a considerable reduction of disability-related costs to be borne by society. The only possibility to be considered, therefore, is a situation that can bring both social and individual advantages, i.e. by increasing the autonomy of those workers who are disabled. 



\section{REFERENTIES}

Aa, R. van der \& Vlaanderen, A. (1991). Een weg met hindernissen. Rotterdam: Erasmus Universiteit, Rotterdams Instituut voor Sociologisch en Bestuurskundig Onderzoek RISBO.

Aarts, L.J.M. \& Jong, Ph.R. de (1990). Economic aspects of disability behavior. Rotterdam: Erasmus Universiteit.

Abberley, P. (1987). The concept of oppression and the development of a social theory of disability. Disability, Handicap and Society, 2, 5-19.

Abberley, P. (1991). The significance of the OPCS disability survey. In: Oliver, M. (ed.). Social Work: Disabled People and Disabling Environments. London: Jessica Kingsley. Ahlgren, C. \& Hammarstrom, A. (1999). Has increased focus on vocational rehabilitation led to an increase in young employees' return to work after work-related disorders? Scandinavian Journal of Public Health, 27, 3, 220-227.

Albrecht, G. (1992). The Disability Business. London: Sage

Amundson, R. (1992). Disability, Handicap and the Environment. Journal of Social Philosophy, 23.

Anthony, W.A \& Jansen, M.A. (1984). Predicting the vocational capacity of the chronically mentally ill: research and policy implications. The American Psychologist, 39, 5, 537 544.

Badley, E.M. (1987). The ICIDH: format, application in different settings, and distinction between disability and handicap; a critique of papers on the application of the International Classification of Impairments, Disabilities, and Handicaps, International Disability Studies, 9, 122-125.

Bandura, A. (1986). Social foundations of thought and action: a social cognitive theory. New York: Prentice-Hall.

Barnes, C. (1994). Disabled people in Britain and discrimination: A case for antidiscrimination legislation, 2nd. edn. London: Hurst \& Company in association with the British council of organisations of disabled people.

Beek, K.W.H. van \& Praag. B.M.S. van (1992). Kiezen uit sollicitanten, concurrentie tussen werkzoekenden zonder baan. Den Haag: Wetenschappelijke Raad voor het Regeringsbeleid (WRR).

Berg, H. van den \& Veer, K. van der (1990 a). Hoezo onbemiddelbaar? Een evaluatic van cen nieuwe methode van arbeidsbemiddeling voor moeilijk plaatsbare werklozen. Amsterdam: Free University Press.

Berg. H. van den \& Veer, K. van der (1990b). De onuitgesproken wens achter de apathie; het woord onbemiddelbaar kan geschrapt. Tijdschrift Sociale Sector. 44, 5, 20-25.

Berg. H. van den \& Veer, K. van der (1993). Wegen naar werk; informatielogistiek bij arbeidsbemiddeling. Amsterdam: VU uitgeverij. 
Berg, W.K., Flynn, T.H. \& Wacker, D.P. (1997). Using hypothesis testing and generalization training to promote maintenance of supported work placement. Journal of Vocational Rehabilitation, 8, 1, 35-42.

Bergers, J. Nijhuis, F., Janssen, M \& Horst, F. van der (1999). Employment Careers of Young Type I Diabetic Patients in The Netherlands. Journal of occupational and environmental medicine, 41, 11, 1005-1010.

Berghoeff, E.L.D., Martijn, A.C. \& Merens-Riedstra, H.S. (1987). Nutteloos of onbenut: een onderzoek naar de belemmeringen voor mensen met een handicap tot het deelnemen aan arbeid. Leiden: Faculteit der Sociale Wetenschappen.

Berkell, D.E. (1987). Career development for youth with autism. Journal of Career Development, 13, 4, 14-20.

Bickenbach, J.E. \& Barnes, C. (1994). Physical disability and social policy, Journal of Social Policy, 23, 3, 42.

Bickenbach, J.E., Chatterji, S., Badley, E.M., Ôstün, T.B. (1999). Models of disablement, universalism and the international classification of impairments, disabilities and handicaps. Social Science \& Medicine, 48, 9, 1173-1187.

Bijl, R.\& Lemmens, F. (1993). Aan het werk: een verkennend onderzoek naar gezondheidsrisico's, arbeidsongeschiktheid en reīntegratie van werknemers in de geestelijke gezondheidszorg. Utrecht: Nederlands Centrum voor Geestelijke Volksgezondheid (NcGv).

Bijlsma, A. (1987). Veel, heel veel met bedrijven praten. Handicap Magazine, mei, 20-21.

Blanck, P.D. (1996). Implementing the Americans with Disabilities Act: 1996 follow-up report on Sears, Roebuck and Co. Spine, 21, 13, 1602-1608.

Bloemhoff, A. \& Winter, C.R. de. (1990). Sociaal-economische status en arbeidsongeschiktheid in longitudinaal perspectief. Leiden: NIPG-TNO.

Bluestone, B. (1989). Employment prospects for persons with disabilities. In: Kiernan, W.E. \& Schalock, R.L. (Eds). Economics, industry, and disability: a look ahead, 17-25. Baltimore: Brookes.

Boer, W.E.L. de, Croon, N.H.Th, Toorn, M. van der \& Csonky-Achilles, H.W. (1996). Enquête medisch arbeidsongeschiktheidscriterium. Tijdschrift voor Bedrijfs- en Verzekeringsgeneeskunde, 4, 98-103.

Bolton, B. \& Akridge, R.L. (1995). A meta-analysis of skills training programs for rehabilitation clients. Rehabilitation Counseling Bulletin, 38, 3, 262-273.

Bont, A. de, Meus, C. \& Hazelaar, G. (1998). Stoornissen, beperkingen en handicaps in de uitvoering. Zoetermeer: CTSV.

Bosselaar, H. \& Heertum, A. van (1993). Als hij/zij maar gezond is! Verslag van een onderzoek naar de mogelijkheden van gedeeltelijk arbeidsongeschikte sollicitanten. Amsterdam: FNV, Secretariaat Uitkeringsgerechtigden en Afdeling Onderzoek.

Bowe, F.G. (1985). Employment trends in the information age. Rehabilitation Counseling Bulletin, 29, 19-25. 
Brejc, T. (1994). Evaluational and counselling interventions provided by a vocational rehabilitation unit. Clinical Rehabilitation, 8, 4, 346-352.

Bremer, W. \& Corten, I. (1990). De bouw en de Wet arbeid gehandicapte werknemers. Amsterdam: Economisch Instituut voor de Bouwnijverheid.

Bruggeman, C. (1991) Reïntegratie van gedeeltelijk arbeidsongeschikten. Nijmegen: De Wetenschapswinkel.

Campbell, J. \& Oliver, M. (1996). Disability politics: understanding our past, changing our future. London: Routledge.

Centraal Bureau voor de Statistiek (CBS) (1997). Enquête beroepsbevolking. Den Haag: SDU.

Centraal Bureau voor de Statistiek (CBS) (1993). Standaard Beroepen Classificatie '92. Den Haag: SDU.

Clark R.A., Anderston, J. \& Skinner, C. (1981). The bronchitic patiēnt: a study of his employment problems. British Journal Diseases of the Chest, 75, 1, 91-94.

Classen, W., Boesken, S., Krajewski, C., Denzer, L. \& Hafer, A. (1993). Cognitive methods in Psychiatric Rehabilitation. Psychiatrische Praxis, 20, 3, 91-94.

College van Toezicht Sociale Verzekeringen (1997). Kroniek van de sociale verzekeringen 1997. Wetgeving en volume-ontwikkeling in historisch perspectief. Zoetermeer: CTSV.

Collijn, D.H., van Lierop, B.A.G. \& Nijhuis, F.J.N. (1996). Arbeids(re)integratie van mensen met een blijvende handicap. Maastricht: Universiteit Maastricht.

Cook, D.W. (1983). Postservice adjustment of former rehabilitation center clients: A longitudinal analysis. Rehabilitation Literature, 44, 7-8, 194-200.

Couch Cole, J. \& Wilkins, R.D. (1989). The use of worksamples in evaluation. Work Adjustment and Independent Living for Disabled People. Wisconsin: Stout University.

Crepeau, F. \& Scherzer, P. (1993). Predictors and indicators of work status after traumatic brain injury: A meta-analysis. Neuropsychological Rehabilitation, 3, 1, 5-35.

Cristol, A.H. (1970). We need sheltered workshops for former mental patients. Mental Hygiene, 54, 3, 444-446.

Cuelenaere, B. (1997), Verder na langdurig verzuim. Een onderzoek naar trajecten van vrouwen en mannen. Rotterdam: Erasmus Universiteit, Vakgroep sociologie.

Damoiseaux, V., Molen, H.T. van der \& Kok, G.J. (1993). Gezondheidsvoorlichting en gedragsverandering. Assen: Van Gorcum.

Danchin, N. (1988). Work capacity after myocardial revascularization; factors related to work resumption. European Heart Journal, 9, suppl. L., 44-47.

Dauwalder, J.P. \& Hoffman, H. (1992). Chronic psychoses and rehabilitation: an ecological perspective. Psychopathology. 25. 3. 139-146.

Dean, D.H., Dolan. R.C. \& Schmidt, R.M. (1999). Evaluating the vocational rehabilitation program using longitudinal data: evidence for a quasi-experimental research design. Evaluation review, 23, 2, 162-189. 
Dear, M., Wilton, R., Lord Gaber, S. \& Takahashi, L. (1997). Seeing people differently: the sociospatial construction of disability. Environment and Planning D: Society and Space, $15,455-480$.

Diethelm, U. \& Schüler, G. (1991). Die Prognose der ankylosierenden Spondylitis. Schweizerische Rundschau für Medizin Praxis, 80, 21, 584-587.

Dijk, F.J.H. van, Haselen, D.A. van \& Lenshoek, D.E. (1987). WAO-toetreding: Trends en risicogroepen in een groot industrieel bedrijf. Tijdschrift Sociale Gezondheidszorg, 20 , 654-662.

Dijker, A. \& Koomen, W. (1996). Stigmatisering van zieken en gehandicapten: een integratie van cognitieve en emotionele componenten Nederlandsch Tijdschrift voor Psychologie, $51,6,252$.

Donker, K.J., Hecke, R.P., Meus, C.J.M., Mullenders, P.H.G.M., Nool, J.W. \& Wijnands, Y. (1996). Toepassing van reĭntegratie-instrumenten voor gedeeltelijk arbeidsgeschikten. Zoetermeer: CTSV

Dooren, H. van (1990). Politiewereld scoort met gehandicaptenbeleid. Handicap Magazine, nov, 24.

Eklund, M. (1992). Chronic pain and vocational rehabilitation: A multifactorial analysis of symptoms, signs, and psycho-socio-demographics. Journal of Occupational Rehabilitation, 2, 2, 53-66.

Elderen, T.M.T. van, Simon, J.G., Toorn, S.L.M. van der \& Maes, C.M.J.G. (1995). Chronisch zieken (on)beperkt aan het werk. Den Haag: VUGA.

Ellison, M.L., Danley, K.S., Bromberg. C. \& Palmer, E.V. (1999). Longitudinal outcome of young adults who participated in a psychiatric vocational rehabilitation program. Psychiatric Rehabilitation Journal, 22, 4, 337-341.

Ernste, D.E., Wijnands, Y., Schooten, P. van \& Baas, L.M. (1995). Reĩntegratieprojecten voor mensen met een arbeidsongeschiktheidsuitkering. Den Haag: VUGA.

Feuerstein, M. \& Therbarge, R.W. (1991). Perceptions of disability and occupational stress as discriminators of work disability in patients with chronic pain. Journal of Occupational Rehabilitation, 1, 3, 185-195.

Finger, A. (1991). First Due. London: Women's Press.

Finkelstein, V. (1980). Attitudes and disabled people: issues for discussion. New York: World Rehabilitation Fund.

Fiseler, J.G., Molenaar-Cox, P.G.M., Kers, W.C. \& Stelt, H.G. van der (1993). Databoek PES-3. Opzet en werkwijze van het onderzoek naar de positie van de WAO-cliēnt. Amsterdam: Gemeenschappelijke Medische Dienst.

Fitzgerald, S.T., Becker, D.M. \& Celentano, D.D. (1989). Return to work after percutaneous transluminal coronary angioplasty. American Journal of Cardiology, 64, 18, 1108-1112.

Fleishman, E.A. \& Quaintance, M.K. (1984).Taxonomies of Human Performance. New York: Academic Press. 
Fougeyrollas, P., Saint-Michel, G. (1991). Proposal of a revised nomenclature of life habits. In: The handicap creation process; analysis of the consultation. New full proposals. ICIDH International Network, 4, 18-20.

French, S. (1994). On equal terms, working with disabled people. Oxford: ButterwordthHeinemann.

Fruhauf, K. (1994). Zur beruflichen Wiedereingliederung von hirnverletzten Patiënten underschiedlichen Lebensalters unter Berücksichtigung neuropsychologischer Aspekte. Rehabilitation, 33, 2, 116-120.

Ganz, P.A. (1990). Current issues in cancer rehabilitation. Cancer, 65, suppl.3, 742-751.

Gartner, A. \& Joe, T. (eds) (1987). Images of the Disabled, Disabling Images. New York: Praeger.

Gehring, J., Koenig, W. \& Rana, N.W. (1988). The influence of the type of occupations on return to work after myocardial infarction, coronary angioplasty and coronary bypass surgery. European Heart Journal, 9, suppl. L, 109-114.

Gemeenschappelijke Medische Dienst (1990). Juridisch Basisboek. Amsterdam: GMD.

Giezen, A.M. van der \& Jehoel-Gijsbers, G.J.M. (1999). Zoekgedrag, bemiddeling en reïntegratie van langdurig arbeidsongeschikten. Amsterdam: LISV.

Gignac, M.A.M \& Cott, C. (1990). A conceptual model of independence and dependence for adults with chronic physical illness and disability. Social Science \& Medicine, 47, 6, 739-753.

Gogstadt, A.C. (1968). Evaluation of Factors Determining the results of vocational rehabilitation. Oslo: Universitetsforlaget.

Granger, B. \& Baron, R.C. (1996). Special article: Agency sponsored entrepreneurial businesses that employ individuals with psychiatric disabilities: Findings from a national survey. VOC, 6, 2, 185-196.

Griffiths, R.D. (1977). The prediction of psychiatric patient's work adjustment in the community. British Journal of Social and Clinical Psychology, 16,2, $165-173$.

Grijpink, P.G.W. (1994). Diabetes mellitus en de bedrijfsgeneeskunde. In: Krans, H.M.J., Heine, R.J., Reeser, H.M. red. De toekomst van de patient met diabetes mellitus. Leiden: Boerhaavecommissie voor Postacademisch onderwijs in de Geneeskunde, 4754.

Grosfeld, J.A.M. (1988). De voorspelbaarheid van de individuele verzuimduur. Nijmegen: Proefschrift Katholieke Universiteit Nijmegen.

Groswasser, Z., Melamed, S., Agranov, E. \& Keren, O. (1999). Return to work as an integrative outcome measure following traumatic brain injury. Neuropsychological Rehabilitation, 9, 3-4, 493-504.

Gründemann, R.W.M. \& Nijboer, I.D. (1998), WAO-intrede en werkhervatting. Amsterdam: NIA TNO 
Haber, L.D. (1990). Issues in the definition of disability and the use of disability survey data. In: Levine, D.B., Zitter, M. \& Ingram, L. (ed.). Disability Statistics: an Assessment Washington DC: National Academy Press.

Hahn, H. (1985). Toward a politics of disability: definitions, disciplines and policies. The Social Science Journal, 22, 4, 87-90.

Hahn, H. (1986). Public support for rehabilitation programs: the analysis of US disability policy. Disability, Handicap and Society, 1, 121.

Hahn, H. (1988). The politics of physical differences: disability and discrimination. Journal of Social Issues, $44,39$.

Hamcock, P.A. (1987). Human Factors Psychology. Amsterdam: North Holland.

Hanssen, W.L. (1985). Revalidatie onder de loupe. Een tijdstudie onderzoek per diagnosegroep. Utrecht: Vereniging van Revalidatiecentra in Nederland (VRIN).

Harlan, S.L. \& Robert, P.M. (1998). The social construction of disability in organizations; why employers resist reasonable accomodation. Work and Occupations, 25, 1, 397-437.

Harris, L.(1995). 1995 survey of corporate executives of the ADA. Washington DC: Louis Harris and Associates Inc.

Hennessey, J.C. \& Muller, L.S. (1995). The effect of voactional rehabilitation and work incentives on helping the disabled-worker beneficiary back to work. Social security bulletin, $58,1,15-28$.

Hevey, D. (1992). The Creatures Time Forgot: Photography and Disability Imagery. London: Routledge.

Hibbeln, J.G. (1993). Het WAO-debacle. Tijdschrift voor Bedrijfs- en Verzekeringsgeneeskunde, 1, 4, 147.

Huurne, A.G. ter, Maas, A.W., Senders, H.P.G.C. (1990). Arbeid en gehandicapte werknemers: stand van zaken in arbeidsorganisaties. Den Haag: VUGA.

Huurne, A.G. ter, Veerman, T.J., Deursen, C.G.L. van, Schellekens, E.I.L.M. \& Vissers, A.M.C. (1997). ZARA-werkgeverspanel rapportage 1996-1997. Ziekteverzuim, arbeidsomstandigheden, reìntegratie en arbeidsongeschiktheid. Den Haag: VUGA.

ICIDH-2 (1999). Internationale classificatie van het menselijk functioneren. Beta-2 voorstel volledige versie. Bilthoven: RIVM.

Imrie, R. (1997). Rethinking the relationships between disability, rehabilitation, and society. Disability and Rehabilitation, 19, 7, 263-271.

Jehoel-Gijsbers, G. \& Giezen, A.M. van der (2000). Na Rea: verbetering in reïntegratie? Amsterdam: LISV.

Johns Jr, R.E., Bloswick, D.S., Elegante, J.M. \& Colledge, A.L. (1994). Chronic, recurrent low back pain: A methodology for analyzing fitness for duty and managing risk under the ADA. Journal of occupational medicine, 36, 5, 537-547.

Johnstone, M. (1966). Models of disability. Psychologist, may, 205-210.

Kaaij, J.J.J. (1992). AGGZ-preventie en arbeid: een praktijk in ontwikkeling. Utrecht: Landelijk Centrum GVO. 
Kalbfleisch, K.R., Lehmann, M.H. \& Steinman, R.T. (1989). Reemployment following implantation of the automatic cardioverter defibrillator. American Journal of Cardiology, 64, 3, 199-202.

Kayser, C.P. (1996). Het verzekeringsgeneeskundig handelen en de verzuimduur: een studie naar het handelen en de takkopvatting van verzekeringsgeneeskundigen en met verzekeringsgeneeskundige taken belaste bedrijfsartsen in de regio Zuid Nederland. Maastricht: Universiteit Maastricht.

Keith, L. (1996). Mustn't grumble. London: Women's Press.

Kenny, D.T. (1995). Common themes, different perspectives: A systemic analysis of employer-employee experiences of occupational rehabilitation. Rehabilitation Counseling Bulletin, 39, 1, 54-77.

Kers, W.C. \& Bruinsma, H. (1989). WAO-toetreden 1987: een verdrijving. Amsterdam: GMD.

Kers, W.C. (1990). Uitkering en werk van WAO-toetreders voor en na de stelselherziening. Sociaal Maandblad Arbeid, 45, 350-360.

Kers, W.C., Stelt, H.G. van der, Fiseler, J.G. \& Molenaar-Cox, P.G.M. (1996). Afvloeiing of herintreding. Wao-toetreding voor en na de stelselherziening 1987. Den Haag: VUGA

Ketting, E. \& Bijl, R.V. (1990). Zorgen voor geestelijke gezondheid in de toekomst: toekomstscenario's geestelijke volksgezondheid en geestelijke gezondheidszorg 1990 2010. Utrecht: Bohn, Scheltema \& Holkema.

Kiernan, W.E., Schalock, R.L. \& Knutson, K. (1989). Economic and demographic trends in influencing employment opportunities for adults with disabilities. In: Kiernan, W.E. \& Schalock, R.L. (Eds). Economics, industry, and disability: a look ahead, 3-16. Baltimore: Brookes.

Kirschenbaum, A. (1999), The organization of vocational rehabilitation: the structure of succes. International Journal of Rehabilitation Research, 22, 3, 215-225.

Kloosterman, R.C. (1987). Achteraan in de rij: een onderzoek naar factoren die (her)intreding van langdurig werklozen belemmeren. Den Haag: SDU.

Koning. P. de \& Vuijk, I. (1989). Van WAO naar WAGW, van uitkering naar arbeid? Een onderzoek naar de ervaringen en meningen van gedeeltelijk arbeidsongeschikten met betrekking tot de herintreding in het arbeidsproces. Rotterdam: Platform WAO/AAW Zuid-Holland, Wetenschapswinkel.

Lamberts, H. (1982). Ziektepatronen in huisartsenpraktijken in Nederland. In Es, J.C., Joossens, J.V., Mandema, E., red. Het medisch jaar 1982. Utrecht: Bohn, Scheltema \& Holkema, 13-36.

Landelijk Instituut Sociale Verzekeringen (1997). Scholing arbeidsdeskundige standaard. Amsterdam: L.ISV.

Landelijk Instituut Sociale Verzekeringen (2000). Kroniek van de sociale verzekeringen 2000. Wetgeving en volume-ontwikkeling in historisch perspectief. Amsterdam: LISV. 
Landelijk Instituut Sociale Verzekeringen (2001). Kerncijfers werknemersverzekeringen 2000. Amsterdam: LISV

Latham, J. \& Davis, B.D. (1994). The socioeconomic impact of chronic pain. Disability and Rehabilitation, 16, 1, 39-44.

Lebesque-van Lierop, B.A.G. \& Nijhuis, F.J.N. (1997). Reĩntegratie na scholing. Maastricht: Universiteit Maastricht.

Lenshoek, D.E., Haselen, D.A. van \& Dijk, F. (1988). Trends en bewegingen bij reïntegratie. Tijdschrift Sociale Gezondheidszorg, 66, 8, 249-252.

Lierop, B. van \& Nijhuis, F. (2000). Assessment, education and placement: an integrated approach to vocational rehabilitation. International Journal of Rehabilitation Research, 23, 261-269.

Lierop, B.A.G. van \& Nijhuis, F.J.N. (in prep.). The influence of personality characteristics on the succes of vocational rehabilitation.

Livneh, H. \& Antonak, R.F. (1997). Psychosocial adaptation to chronic illness and disability. Gaithersburg: Aspen Publishers inc.

Lubbe, T. (1990). "Buitenstaanders": rapport project verbetering scholings- en arbeidsmarktpositie van mensen met een lichamelijke handicap, in het bijzonder schoolverlaters. Den Haag: Provinciaal overleg Gehandicaptenbeleid Zuid Holland.

Maas, J.M.A.G., Dongen, A. van \& Hamers, P. (1990). De arbeidsmarktpositie in het onderwijs voor gehandicapten. Tilburg: Instituut voor Sociaal-Wetenschappelijk onderzoek (IVA).

Mann, K. (1994). Winners: Characteristics of highly succesful rehabilitation clients. Vocational Rehabilitation and Work Adjustment Bulletin, 27, 1, 15-18.

Mannila, S. (1995). Factors influencing the disabled's employment in the competitive labour market. International journal of rehabilitation research, 18, 1, 19-26.

Mark, D.B., Lam, L.C., Lee, K.L., Clapp-Channing, N.E., Williams, R.B., Pryor, D.B., Califf, R.M. \& Hlatky, M.A. (1992). Identification of patients with coronary disease at high risk for loss of employment: A prospective validation study. Circulation, 86, 5, 1485 1494.

Markenson, J.A. (1991). Worldwide trends in the socioeconomic impact and long-term prognosis of rheumatoid arthritis. Seminars in Arthritis and Rheumatism, 21, 2, suppl. I. 4-12.

Marks, D. (1997). Models of disability. Disability and Rehabilitation, 19, 3, 85-91

Maso, I. (1989). Kwalitatief onderzoek. Meppel/Amsterdam: Boom.

Meyerson, L. (1988). The social psychology of disability: 1948 and 1988. Journal of social issues, 44,173 .

Michaels, C.A. \& Risucci, D.A. (1993). Employer and counselor perceptions of workplace accommodations for persons with traumatic brain injury. Journal of Applied Rehabilitation Counseling. 24, 1, 38-46. 
Michon, H. \& van Weeghel, J. (1990). Werken met handicaps: een verkennend onderzoek naar de positie van gehandicapten op de Nederlandse arbeidsmarkt. Utrecht: Nederlands Centrum voor Geestelijke Volksgezondheid.

Mitchell, J.M. (1991). Work behavior after the onset of arthritis. Medical Care, 29, 4, 362376.

Molenaar-Cox, P.G.M. \& Prins, R. (1998). Het werkhervattingsproces na een WAObeoordeling. Arbeidssituatie, zoekgedrag en bemiddeling van toetredingsgekeurden. Zoetermeer: College van Toezicht Sociale Verzekeringen (CTSV).

Morgan, J.M. \& O'Connell, J.C. (1987). The rehabilitation of disabled Native Americans. International Journal of Rehabilitation Research, 10, 2, 139-149.

Morris, J. (1991). Pride against Prejudice: Transforming Attitudes to Disability. London: Women's Press.

Muffels, R.J.A., Rietveld, J. \& Vriens, M. (1990). Langdurig werklozen op de arbeidsmarkt: determinanten van arbeidsmarktgedrag en implicaties voor beleid. Tilburg: Katholieke Universiteit Brabant.

Mul, C.A.M. (1999). Schadebeoordeling en FCE-methoden : een studie naar de toepassingsmogelijkheden van zes FCE-methoden bij de schadebeoordeling door private verzekeraars van arbeidsongeschiktheid bij zelfstandigen. Hoofddorp: TNO Arbeid.

Mul, C.A.M., Winter, C.R. de, Nijboer, I.D. \& Haan, H.F. de (1995). Methoden voor de (re)integratie van gedeeltelijk arbeidsgeschikten. Den Haag: VUGA.

Munhall, P.L. \& Boyd, C.O. (1993). Nursing research. A qualitative perspective. New York: National League for Nursing Press.

Munro, M.S. (1990). Work before and after coronary artery bypass grafting. Journal of the Society of Occupational Medicine, 40, 2, 59-64.

Murphy, R.F., Scheer, J., Murphy, Y. \& Mack, R. (1988). Physical disability and social liminality: a study in the rituals of adversity. Social Science \& Medicine, 26, 235-242.

Nagi, S.Z. (1991). Disability concepts revisted: implications for prevention. In: Disability in America: toward a National Agenda for Prevention (Ed: Pope, A.M. \& Tarlov, A.R.). Washington DC: National Academy Press.

Nationale Raad voor de Volksgezondheid (1994). Definities en classificaties van arbeidsongeschiktheid. Een voorstudie van de WCC. Zoetermeer: Nationale Raad voor de Volksgezondheid.

Nijboer, I.D., Gründeman, R.W.M. \& Andries, F. (1993). Werkhervatting na arbeidsongeschiktheid. Den Haag: VUGA.

Nijhuis F.J.N. \& Soeters, J. (1983). Ziekteverzuim, arbeidsongeschiktheid en de organisatie van de arbeid. Tijdschrift Sociale Gezondheidszorg, 61, 686-693

Nijhuis, F.J.N. (1984). Beoordelingen van organisatiekenmerken. Maastricht: Universiteit Maastricht.

Nijhuis, F.J.N. \& Bullinga, R. (1987). Reĩntegratiebeleid in organisaties. Tijdschrift Sociale Gezondheidszsorg, 65, 25, 816-821. 
Nijhuis, F.J.N. \& Lebesque - van Lierop, B.A.G. (1999). Disability management. Een integrale benadering van arbeids(reintegratie. Gedrag en organisatie : tijdschrift voor sociale, arbeids- en organisatie-psychologie, 12, 6, 413-426.

Noble, J.H.J. \& Collignon, F.C. (1987). Systems barriers to supported employment for persons with chronic mental illness. Psychosocial Rehabilitation Journal, 11, 2, 25-44.

Nool, J.W., Spijkerboer, P.M. \& van Breukelen, A.H. (1996). In en uit de WAO: een onderzoek naar volume-ontwikkeling en werkhervatting. Zoetermeer: CTSV

Nyfer (1998). Marktwerking in de sociale zekerheid. Breukelen: Nyfer

Oliver, M. (1990a). The Politics of Disablement: A Sociological Approach. Basingstoke: Macmillan.

Oliver, M. (1990b). Disablement in Society: a Socio-Political Approach. London: Thames Polytechnic.

Oliver, M. (1993). Disability and participation in the labour market. Basingstoke: Macmillan.

Oliver, R.L. (1980). A cognitive model of of the antecedents and consequences of satisfaction decisions. Journal of Marketing Research. 17, 11, 460-469.

Parente, R. \& Stapleton, M. (1996). Vocational evaluation, training, and job placement after traumatic brain injury: problems are solutions. Journal of Vocational Rehabilitation, 7 , $3,181-191$.

Parlementaire enquête (1993). Enquête naar het functioneren van de organen belast met de uitvoering van de sociale verzekeringswetten. Den Haag: SDU.

Parsons (1951). The social system. Glencoe, Ill.: Free Press.

Partridge, J. (1990). Changing faces: the challenge of facial disfigurement. London: Penguin.

Pfeiffer (1999). The categorization and control of people with disabilities. Disability and Rehabilitation, 21, 3, 106-107.

Philips. C.A. (1989). Rehabilitation of the patient with rheumatoid hand involvement. Physical Therapy, 69, 12, 1091-1098.

Polit, D.F. \& Hungler, B.P. (1999). Nursing Research: Principles and methods (6th edition). Philadelphia: Lippincott Williams \& Wilkins.

Regenold, M., Sherman, M.F. \& Fenzel, M. (1999). Getting back to work: Self-efficacy as a predictor of employment outcome. Psychiatric Rehabilitation Journal, 22, 4, 361-367.

Reihl, D. (1988). Kooperationsaspekte bei der beruflichen Integration psychische Kranker; wie sehen Nervenărtze und Mitarbeiter psycosoizialer Einrichtungen ihre Kooperationsbeziehungen mit Betrieben? Gruppendynamik, 19, 2, 189-209.

Reneman, M.F., Jaegers, S.M.H.J, Muskee, J., Schroêr, H.Th. \& Göeken, L.N.H. (1997). Functional Capacity Evaluation: toepassing in Nederland? Tijdschrift voor Bedrijfs- en Verzekeringsgeneeskunde, 5, 4, 139-146.

Riipinen, M., Hurri, H. \& Alaranta, H. (1994). Evaluating the outcome of vocational rehabilitation. Scandinavian Journal of Rehabilitation Medicine, 26, 103-112. 
Roe, R.A. (1984). Individuals characteristics. In: Handbook of Work and Organizational Psychology (edited by P.J.D. Drenth, P.J. Willems \& C.H.J. de Wolff), pp. 103-130. Chicester: Wiley

Rosenthal, A.M. (1974). Rehabilitation of the patient with chronic low back pain. Illinois Medical Journal, 146, 3, 189-190, 223.

Russel, R.O., Abi-Mansour, P. \& Wenger, N.K. (1986). Return to work after coronary bypass surgery and percutaneous transluminal angioplasty; issues and potential solutions. Cardiology, 73, 4-5, 306-322.

Sandström, J. (1986). Clinical and social factors in rehabilitation of patients with chronic low back pain. Scandinavian Journal of Rehabilitation Medicine, 18, 1, 35-43.

Schmidt, S.H., Oort-Maarburger, D. \& Meijman, T.F. (1995). Employment after rehabilitation for musculoskeletal impairments: the impact of vocational rehabilitation and working on a trial basis. Archives of physical medicine and rehabilitation, 76, 10, 950-954.

Schultz-Johnson, K. (1987). Evaluating the worker's functional capacities for repetitive work. Seminars in Occupational Medicine, 2, 1, 31-39.

Schwab, A.J. \& Dinitto, D.M. (1993). Factors related to the succesful vocational rehabilitation of substance abusers. Journal of Applied Rehabilitation Counseling, 24, 3, 11-20.

Selander, J., Marnetof,, S.V., Bergroth, A. \& Ekholm, J. (1998). Vocational rehabilitation and future sick-leave. Disability and Rehabilitation, 20, 2, 49-54.

Smith, G.R. \& O'Rourke, D.F. (1988). Return to work after a first myocardial infarction. A test of multiple hypotheses. Journal of the American Medical Association, 259, 11 , 1673-1677.

Sonsbeek, J.K.L. \& Verwey, G.C.G. (1991). Arbeidsparticipatie van personen met lichamelijke beperkingen. Maandberichten Gezondheidsstatistiek, 9, 5, 5-13.

Spruit, I.P., Nieuwe Giessen, J.D. van de \& Nes-Achilles, H.W. (1986). Reïntegratie van gedeeltelijk arbeidsongeschikten in het arbeidsproces; kernbevindingen van een onderzoek naar belemmerende en bevorderende factoren. Leiden: Rijksuniversiteit Leiden, Instituut voor Sociale Geneeskunde.

Stavenuiter, M.M.J. (1999). Van verzekering voor 'oude werklieden' tot WAO. Demos, 15. $10,1-6$.

Stelt, H.G. van der \& Bruinsma, H. (1989). De reintegratie van arbeidsongeschikten in het arbeidsproces. Sociaal Maandblad Arbeid, 44, 1, 659-668.

Stelt, H.G., van der, Fiseler, J.G., Smaal, M. Molenaar-Cox, P.G.M. \& Kers, W.C. (1996). De WAO als eindstation? Onderzoek naar de veranderingen in de arbeidsongeschiktheidssituatie van WAO'ers. Den Haag: VUGA.

Straaton, K.V., Maisiak, R., Wrighley, M., White. M.B., Johnson, P. \& Fine, P.R. (1996). Barriers to return to work among persons unemployed due to arthritits and musculosketal disorders. Arthritis and Rheumatism, 39, 1, 101-109.

Taylor, M.E. (1989). Return to work following back surgery: a review. American Journal of Industrial Medicine, 16, 1, 79-88. 
Thomas, D.F. \& Menz, F.E. (1996). Functional assessment of vocational skills and behaviors of persons with brain trauma injuries. Journal of Vocational Rehabilitation, 7, 243-256.

Unger, K. (1994). Access to educational programs and its effect on employability. Psychosocial Rehabilitation Journal, 17, 3, 117-126.

Upias (1976). Fundamental Principles of Disability. London: Union of the Physically Impaired Against Segregation.

Veerman, T.J. \& Cavé, M. (1993). Werkgevers over herintredende WAO'ers en hun ziekteverzuim; meningen en selectiebeleid van werkgevers geīnventariseerd. Den Haag: Ministerie van Sociale Zaken en Werkgelegenheid.

Veerman, T.J. \& Cavé, M. (1994). Reĭntegratieprocessen bij oude en nieuwe werkgevers. Sociaal Maandblad Arbeid, 49, 2, 79-90.

Velema, W. (1993). Alle macht aan de verzekeraars. Intermediair, 29, 6, 11-14.

Velicer, W.F., Rossi, J.S., Prochaska, J.O. \& Diclemente, C.C. (1996). A criterion measurement model for health behavior change. Addictive behaviors : an international journal, 21, 5, 555-584.

Verbrugge, L.M. \& Jette, A.M. (1994). The disablement process. Social Science \& Medicine, $38,1,1-14$.

Verkleij, H.G.M. (1988). Langdurige werkloosheid, werkhervatting en gezondheid: bevindingen van een 2-jarige follow-up studie. Amsterdam: Swets \& Zeitlinger.

Vries, H. de, Kuhlman, P. \& Dijkstra, M. (1987). Persoonlijke effectiviteit: de derde variabele naast attitude en subjectieve norm als voorspeller van de gedragsintentie. Tijdschrift voor Gezondheidsbevordering, 8, 253-264.

Vroom, J.C.M.J. de \& Willems, E.J. (1992). TAV: wet terugdringing arbeidsongeschiktheidsvolume. Deventer: Kluwer. PS: periodiek voor sociale verzekering, sociale voorziening en arbeidsrecht, 7.

Weis, J. (1993). Arbeitszufriedenheit und Arbeidsplatzgestaltung bei psychische Kranken in Einrichtungen der beruflichten Rehabilitation. Zeitschrift für Arbeits- und Organisationspsychologie, 37, 11/1, 29-32.

Weiser, S. \& Cedraschi, C. (1992). Psychosocial issues in the prevention of chronic low-back pain; a literature review. Baillières Clinical Rheumatology, 6, 3, 657-684.

West, M.D. (1996). Assisting individuals with brain injuries to return to work: new paradigms of support. Journal of Vocational Rehabilitation, 7, 143-149.

Wevers, C.W.J., Nijboer, I.D. \& Andries, F. (1993). Arbeidsmarktpositie chronisch zieken; overzichtsstudie naar Nederlandse literatuur van de laatste tien jaar, databestanden en lopende arbeidsprojecten. Zoetermeer: Nationale Commissie Chronisch Zieken (NCCZ).

Wevers, C.W.J. (1997). Research-nota reĩntegratie instrumenten. Den Haag: VUGA.

Wilgosh. L. \& Muller, H.H. (1993). Work skills for disadvantaged and unprepared youth and adults. International Journal for the Advancement of Counselling. 16, 2, 99-105. 
Wöhrl, H.G. (1990). Eingliederungschancen von Absolventen des Berufsförderungswerke (BFW) Heidelberg mit einer psychischen Behinderung. Rehabilitation, 29, 2, 84-92.

Woodyard, J.E. (1980). Injury, compensation claims and prognosis, part II. Journal Social \& Occupational Medicine, 30, 57-60.

Wright, B. (1983). Physical Disability: a Psychosocial approach, 2nd ed. New York: Harper \& Row.

Yelin, E. (1986). The myth of malingering: why individuals withdraw from work in the presence of illness. Milbank Quarterly, 64, 4, 622-649.

Zola, 1. (1982). Denial of Emotional Needs to People with Handicaps. Archives of Physical Medicine and Rehabilitation, 63, 63-67. 

BIJLAGE 1 


\begin{tabular}{|c|c|c|c|c|c|c|}
\hline \multirow[t]{2}{*}{ Tabel 6.2a } & Hocnsbroeck: & \multicolumn{5}{|c|}{$\begin{array}{l}\text { Conrelaties tussen de onafhankelijke persoonsgebonden factoren en de afhankelijke factor } \\
\text { persoonlijke ontwikkeling en de individuele afhankelijke variabelen binnen deac factor ( } \mathrm{n}-199 \text { ) }\end{array}$} \\
\hline & $\begin{array}{l}\text { Persoonlijke } \\
\text { ontwikkeling }\end{array}$ & $\begin{array}{l}\text { Zelf- } \\
\text { vertrouwen }\end{array}$ & $\begin{array}{l}\text { Omgaan met } \\
\text { beperkingen }\end{array}$ & $\begin{array}{l}\text { Sociale } \\
\text { vaardigheden }\end{array}$ & $\begin{array}{l}\text { Incasserings- } \\
\text { vermogen }\end{array}$ & $\begin{array}{l}\text { Functioncren } \\
\text { arbeidsmarkt }\end{array}$ \\
\hline Leeftijd & 13 & $.15 *$ & -.04 & $.17^{*}$ & 13 & .06 \\
\hline Geslacht & $-20^{*}$ & $-17^{\circ}$ & -.12 & $-.16^{\circ}$ & $-.15^{\circ}$ & -.10 \\
\hline Hoogste opl. & -.05 & .03 & -.07 & -.11 & .01 & .04 \\
\hline Arbeidsverleden & -.01 & .04 & -.09 & .01 & .03 & .07 \\
\hline $0.01<p$ & $\leqslant 0.05$ & & & & & \\
\hline \multirow[t]{2}{*}{ Tabel 6.2b } & Werkenrodk: & \multicolumn{5}{|c|}{$\begin{array}{l}\text { Correlaties tussen de onafhankelijke persoonsgebonden factoren en de afhankelijke factor } \\
\text { pernoontijke ontwikkeling en de individuele afhankelijke variabelen binnen deze factor ( } n=58)\end{array}$} \\
\hline & $\begin{array}{l}\text { Persoonlijke } \\
\text { ontwikkeling }\end{array}$ & $\begin{array}{l}\text { Zelf- } \\
\text { vertrouwen }\end{array}$ & $\begin{array}{l}\text { Omgaan met } \\
\text { beperkingen }\end{array}$ & $\begin{array}{l}\text { Sociale } \\
\text { vaardigheden }\end{array}$ & $\begin{array}{l}\text { Incasserings- } \\
\text { vermogen }\end{array}$ & $\begin{array}{l}\text { Functioneren } \\
\text { arbeidsmarkt }\end{array}$ \\
\hline Leeftijd & .09 & .06 & .06 & 05 & 13 & $.46^{\circ}$ \\
\hline Geslacht & -01 & .06 & .03 & .04 & -.15 & -.15 \\
\hline Hoogste opl. & 03 & 15 & .04 & 01 & .10 & -.11 \\
\hline Arbeidsverleden & -.18 & .19 &,- 17 & -15 & .06 & -.01 \\
\hline
\end{tabular}

\begin{tabular}{|c|c|c|c|c|c|c|}
\hline \multirow[t]{2}{*}{ Tabel 6.2e } & Sonncheerdt: & \multicolumn{5}{|c|}{$\begin{array}{l}\text { Correlaties tussen de onafhankelijke persoonsgebonden factoren en de afhankelijke factor } \\
\text { persoonlijke ontwikkeling en de individuele afhankelijke variabelen binnen deze factor (n-77) }\end{array}$} \\
\hline & $\begin{array}{l}\text { Persoonlijke } \\
\text { ontwikkeling }\end{array}$ & $\begin{array}{l}\text { Zelf- } \\
\text { vertrouwen }\end{array}$ & $\begin{array}{l}\text { Omgaan met } \\
\text { beperkingen }\end{array}$ & $\begin{array}{l}\text { Sociale } \\
\text { vaardigheden }\end{array}$ & $\begin{array}{l}\text { Incasserings- } \\
\text { vernogen }\end{array}$ & $\begin{array}{l}\text { Functioneren } \\
\text { arbeidsmarkt }\end{array}$ \\
\hline Leeftijd & -.13 & -.12 & $-.25^{\circ}$ & 02 & -.07 & .19 \\
\hline Geslacht & .08 & .06 & .09 & .04 & .03 & .18 \\
\hline Hoogste opl. & .03 & 01 & .09 & .05 & -.03 & -11 \\
\hline Arbeidsverleden & .04 & -.06 &,- 13 & .06 & $25^{*}$ & .15 \\
\hline
\end{tabular}

\begin{tabular}{|c|c|c|}
\hline Tabel 6.2d & Heliomare: & $\begin{array}{l}\text { Correlaties tusien de onaftankelijke pernoonsgebonden factoren en de aftankelijke factor } \\
\text { persoonlijke ontwikkeling en de individuele aftankelijke variabelen binnen dese factor (n-97) }\end{array}$ \\
\hline
\end{tabular}

$\begin{array}{llllll}\begin{array}{l}\text { Persoonlijke } \\ \text { ontwikkeling }\end{array} & \begin{array}{l}\text { Zelf- } \\ \text { vertrouwen }\end{array} & \begin{array}{l}\text { Omgaan met } \\ \text { beperkingen }\end{array} & \begin{array}{l}\text { Sociale } \\ \text { vaardigheden }\end{array} & \begin{array}{l}\text { Incasserings- } \\ \text { vermogen }\end{array} & \begin{array}{l}\text { Functioneren } \\ \text { arbeidsmarkt }\end{array}\end{array}$

\begin{tabular}{lcccccc} 
Leefijd & .09 & $-.30 * *$ & -.08 & $.37 * 0$ & .20 & .13 \\
Geslacht & -.02 & -.01 & .03 & .04 &. .14 & .04 \\
Hoogste opl. & .09 & .01 & .05 & .11 & .06 & .12 \\
Arbeidsverleden & .05 & -.15 & -.09 & .17 & .14 \\
\hline
\end{tabular}

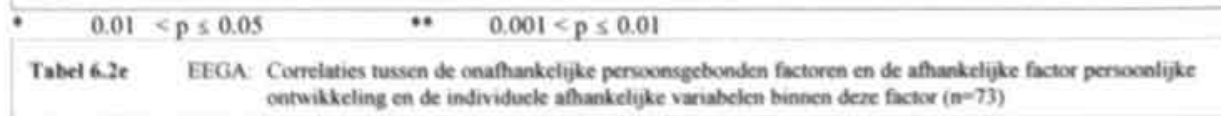

$\begin{array}{llllll}\text { Persoonlijke } & \text { Zelf- } & \begin{array}{l}\text { Omgaan met } \\ \text { beperkingen }\end{array} & \begin{array}{l}\text { Sociale } \\ \text { vaardigheden }\end{array} & \begin{array}{l}\text { Incasserings- } \\ \text { vermogen }\end{array} & \begin{array}{l}\text { Functioneren } \\ \text { arbeidsmarkt }\end{array}\end{array}$

\begin{tabular}{|c|c|c|c|c|c|c|}
\hline Leeftijd & 02 & -01 & 01 & -.15 & .17 & -12 \\
\hline Geslacht & -.05 & -.05 & .06 & -.14 & -.04 & -.05 \\
\hline Hoogste opl. & .01 & .04 &,- 09 & .06 & -.03 & 01 \\
\hline Arbeidsverleden & .03 & 16 & -.08 & 02 & 01 & -.02 \\
\hline
\end{tabular}


Tabel 6.3a Hoensbroeck: Correlaties tussen de onafhankelijke persoonsgebonden factoren en de individucle afhankelijke variabelen binnen de factor plaatsing $(n=199)$

Aantal aanpassingen Werk op korte termijn Werk op lange termijn Aansluiting baan bij scholing

\begin{tabular}{|c|c|c|c|c|}
\hline Leeftijd & 03 & $-18^{\circ}$ & $-15^{\circ}$ & $=.04$ \\
\hline Geslacht & 13 & 05 & -.04 & $=, 10$ \\
\hline Hoogste opl. & 05 & .00 & -10 & .02 \\
\hline Arbeidsverleden & -.06 & -.01 & -.06 & -07 \\
\hline $0.01<\mathrm{p}$ & $p \leq 0.05$ & & & \\
\hline \multirow[t]{2}{*}{ Tabel 6.3b } & $\begin{array}{l}\text { Correla } \\
\text { afhanke }\end{array}$ & \multicolumn{3}{|c|}{$\begin{array}{l}\text { Correlaties tussen de onafhankelijke persoonsgebonden factoren en de individuele } \\
\text { afhankelijke variabelen binnen de factor plaatsing }\left(n^{-58)}\right.\end{array}$} \\
\hline & Aantal aanpassingen & Werk op korte termijn & Werk op lange termijn & Aansluiting baan bij scholing \\
\hline Leeftijd & .01 & -.16 & .09 & .03 \\
\hline Geslacht & $.33^{*}$ & .05 & -.20 & .12 \\
\hline Hoogste opl. & $33^{\circ}$ & -.01 & -10 & 05 \\
\hline Arbeidsverleden & -.18 & 19 & .06 &,- 15 \\
\hline
\end{tabular}

- $0.01<\mathrm{p} \leq 0.05$

Tabel 6.3c Sonneheerdt: Correlaties tussen de onafhankelijke persoonsgebonden factoren en de individuele afhankelijke variabelen binnen de factor plaatsing ( $n=77$ )

Aantal aanpassingen Werk op korte termijn Werk op lange termijn Aansluiting baan bij scholing

\begin{tabular}{|c|c|c|c|c|}
\hline Leeftijd & .17 & .01 & -.06 & .09 \\
\hline Geslacht & -.20 & .07 &. .22 & 17 \\
\hline Hoogste opl. & .20 & -.16 & -.03 & .04 \\
\hline Arbeidsverleden & -.01 & 13 & 04 & 09 \\
\hline
\end{tabular}

$0.01<\mathrm{p} \leq 0.05$

Tabel 6.3d Heliomare: Correlaties tussen de onafhankelijke persoonsgebonden factoren en de individuele afhankelijke variabelen binnen de factor plaatsing $(n-97)$

Aantal aanpassingen Werk op korte termijn Werk op lange termijn Aansluiting baan bij scholing

\begin{tabular}{lrrrr} 
Leeftijd & .12 & -.09 & .09 & .09 \\
Geslacht & .17 & -.04 & .07 & -07 \\
Hoogste opl. & $.35 * *$ & .16 & .14 & -23 \\
Arbeidsverieden & .05 & $-.23 *$ & .03 & .12 \\
\hline$\quad 0.01<p \leq 0.05$ & $*$ & $0.001<p \leq 0.01$ &
\end{tabular}

Tabel 6.3e EEGA: Correlaties tussen de onafhankelijke persoonsgebonden factoren en de individuele afhankelijke variabelen binnen de factor plaatsing $(n=73)$

Aantal aanpassingen Werk op korte termijn Werk op lange termijn Aansluiting baan bij scholing

$\begin{array}{lccc}\text { Leeftijd } & -.11 & .04 & -.18 \\ \text { Geslacht } & .03 & .17 & -.02 \\ \text { Hoogste opl. } & -.21 & .00 & -.16 \\ \text { Arbeidsverleden } & -.03 & .17 & .06\end{array}$




\begin{tabular}{|c|c|c|c|c|c|}
\hline \multirow[t]{3}{*}{ Tabei 6.ts } & Hoenibrocec: & \multicolumn{4}{|c|}{ 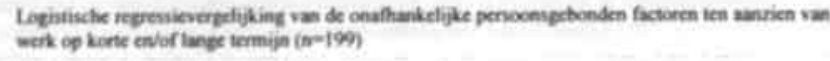 } \\
\hline & & \multicolumn{2}{|l|}{ Wekt op hone iermijn } & \multicolumn{2}{|c|}{ Wek op lanes iermijn } \\
\hline & & $B($ S.E. $)$ & $\operatorname{Exp}(B)$ & $B$ (S.E.) & $\operatorname{Exp}(B)$ \\
\hline Leeflijd & & $-.09(.03)^{40}$ & $91 * 0$ & $.06(.03)$ & 94 \\
\hline Geslacht & & $.16(72)$ & 1.17 & $-.59(.68)$ & 55 \\
\hline Hoogite opt. & & $.07(.19)$ & 1.07 & $-.20(.20)$ & $\$ 2$ \\
\hline \multicolumn{2}{|l|}{ Arbeidsverleden } & $1.11(62)$ & 3.03 & $-.04(.75)$ & 96 \\
\hline \multicolumn{6}{|c|}{$0.001<p<0.01$} \\
\hline \multirow{3}{*}{\multicolumn{2}{|c|}{ Tabel 6.4h }} & \multicolumn{4}{|c|}{ 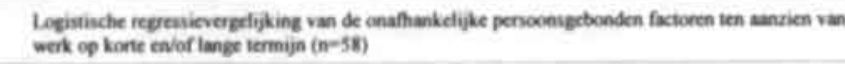 } \\
\hline & & \multicolumn{2}{|l|}{ Werk op konte iermijn } & \multicolumn{2}{|c|}{ Werk op lanes lermijn } \\
\hline & & B (S.E.) & $\operatorname{Exp}(B)$ & B (S.E.) & $\operatorname{Exp}(B)$ \\
\hline Leefijd & & $.29(.12)^{\bullet}$ & $.75^{\circ}$ & $-.14(.12)$ & 87 \\
\hline Geslacht & & $62(.85)$ & 1.87 & $-1.09(.88)$ & 34 \\
\hline Hoogste ept. & & $27(.61)$ & 1.31 & $-.09(61)$ & 91 \\
\hline Arbeidsverleden & & $2.77(1.12)^{* 0}$ & $15.99 * 4$ & $.62(1.07)$ & 1.85 \\
\hline
\end{tabular}

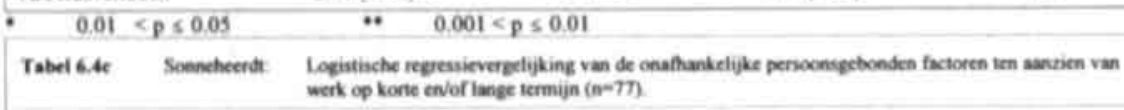

\begin{tabular}{|c|c|c|c|c|}
\hline & \multirow{2}{*}{$\begin{array}{c}\text { Werk ep konte termijn } \\
\text { B (S.E.) }\end{array}$} & \multicolumn{3}{|c|}{ Werk op lange termijn } \\
\hline & & $\operatorname{Exp}(B)$ & B (S.E) & $\operatorname{Exp}(B)$ \\
\hline Leentijd & $02(.05)$ & 1.01 & $.04(.05)$ & .96 \\
\hline Geslacht & $-36(.55)$ & .70 & $-1,16(.55)^{*}$ & 32 \\
\hline Hoogste opl. & $-42(30)$ & .66 & $.02(.30)$ & 1.02 \\
\hline Artedidsveriaden & $.09(.69)$ & 1.09 & $52(.71)$ & 1.69 \\
\hline
\end{tabular}

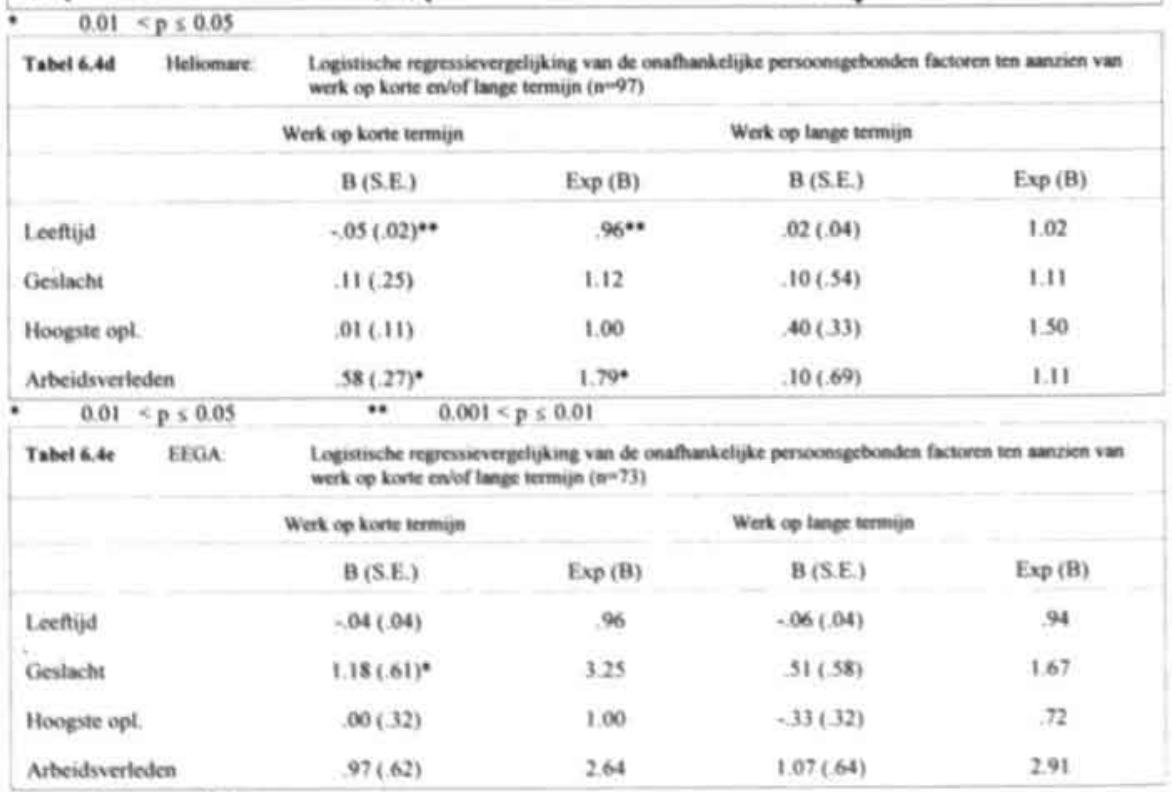

* $0.001<p \leq 0.01$ 
Tabel 6.10a Hoenshroeck: Correlaties tussen de variabelen van het seholingsprogramma en de variabelen binnen de factor persoonlijke ontwikkeling $(\mathrm{n}=199)$.

\begin{tabular}{|c|c|c|c|c|c|c|}
\hline & $\begin{array}{l}\text { persoconlijke } \\
\text { ontwikkeling }\end{array}$ & $\begin{array}{l}\text { zelf. } \\
\text { vetrouwen }\end{array}$ & $\begin{array}{l}\text { omgaan met } \\
\text { beperkineten }\end{array}$ & $\begin{array}{l}\text { sociale } \\
\text { vaurdieheden }\end{array}$ & $\begin{array}{l}\text { incasserings: } \\
\text { vermogen }\end{array}$ & $\begin{array}{l}\text { functioneren } \\
\text { arbeidumakt }\end{array}$ \\
\hline $\begin{array}{l}\text { Aansluiting } \\
\text { scholingsprogramma }\end{array}$ & .12 & .11 & .07 & .13 & .06 & $.17^{*}$ \\
\hline $\begin{array}{l}\text { Begeleiding bij } \\
\text { persoonlijke problemen }\end{array}$ & .2100 & $.15^{\circ}$ & $.21 * 0$ & .08 & $.19^{\circ}$ & .12 \\
\hline Theoretische vorming & .05 & .07 & .10 & .08 &., 09 & .11 \\
\hline Praktische vorming & .08 & .13 & .07 & .08 & .01 & $.22 *$ \\
\hline Kwaliteit lesmateriaal & -.01 & .02 & .08 & -.02 & .10 & .05 \\
\hline Niveau & .14 & $.14^{\circ}$ & .07 & $.18^{\circ}$ & .04 & $.14^{\circ}$ \\
\hline Tempo & .11 & .11 & .08 & .12 & .04 & .10 \\
\hline Begeleiding onderwijs & .07 & .14 & .03 & 13 & .02 & $.24 * 0$ \\
\hline Didactische kwaliteit & -.01 & .03 & .01 & .02 & 03 & .10 \\
\hline Studiebegeleiding & .09 & 02 & .09 & .07 & .10 & .05 \\
\hline
\end{tabular}

$0.01<\mathrm{p} \leq 0.05$

$* \quad 0.001<\mathrm{p} s 0.01$

Tabel 6.10b Werkenrode: Correlaties tussen de variabelen van het scholingsprogramma en de variabelen binnen de factor persoonlijke ontwikkeling ( $n-58)$.

\begin{tabular}{|c|c|c|c|c|c|c|}
\hline & $\begin{array}{l}\text { persoonlijke } \\
\text { ontwikkeling }\end{array}$ & $\begin{array}{l}\text { zelf- } \\
\text { vertrouwen }\end{array}$ & $\begin{array}{l}\text { ompaan met } \\
\text { beperkingen }\end{array}$ & $\begin{array}{l}\text { sociale } \\
\text { vaardigheden }\end{array}$ & $\begin{array}{l}\text { incasserines: } \\
\text { vermogen }\end{array}$ & $\begin{array}{l}\text { functioneren } \\
\text { arbeidsmakt }\end{array}$ \\
\hline $\begin{array}{l}\text { Aansluiting } \\
\text { scholingsprogramma }\end{array}$ & .15 & .26 & .10 & .08 & 06 & 19 \\
\hline $\begin{array}{l}\text { Begeleiding bij } \\
\text { persoonlijke problemen }\end{array}$ & .03 & .13 & .23 & -11 &,- 19 &, 00 \\
\hline Theoretische vorming & .04 & 01 & .14 & -.09 & .06 & 25 \\
\hline Praktische vorming & .09 & 17 & .12 & .03 & -.06 & .00 \\
\hline Kwaliteit lesmateriaal & -.13 & -.22 & -.23 & 02 & .02 & -01 \\
\hline Niveau & .18 & $31^{\bullet}$ & .08 & 09 & .14 & .18 \\
\hline Tempo & $35 *$ & $39 \bullet \bullet$ & 22 & 20 & $30^{\circ}$ & $50 * 0$ \\
\hline Begeleiding onderwijs & .04 & 07 & -.05 & .18 & -.08 & 02 \\
\hline Didactische kwaliteit & .08 & $29^{\circ}$ & .10 & .06 & -21 & II \\
\hline Studiebegeleiding & .03 & 10 & .12 & -.03 & .00 & -.07 \\
\hline
\end{tabular}

$0.01<p \leq 0.05$

* $\quad 0.001<p \leq 0.01$ 


\begin{tabular}{|c|c|c|c|c|c|c|}
\hline \multirow[t]{2}{*}{ Sonneheendt: } & \multicolumn{6}{|c|}{$\begin{array}{l}\text { Correlaties tussen de variabelen van het scholingsprogramma en de variabelen binnen de } \\
\text { factor persoonlijke ontwikkeling ( } \mathrm{n}=77 \text { ). }\end{array}$} \\
\hline & $\begin{array}{l}\text { pernoonlijke } \\
\text { ontwikkeling }\end{array}$ & $\begin{array}{l}\text { zelf- } \\
\text { vertrouwen }\end{array}$ & $\begin{array}{l}\text { omgan met } \\
\text { beperkingean }\end{array}$ & $\begin{array}{l}\text { sociale } \\
\text { vaurdigheden }\end{array}$ & $\begin{array}{l}\text { incasserings: } \\
\text { vermogen }\end{array}$ & $\begin{array}{l}\text { functioncren } \\
\text { arteidsmarkt }\end{array}$ \\
\hline $\begin{array}{l}\text { Aansluiting } \\
\text { scholingsprogramma }\end{array}$ & .20 & $.29^{*}$ & .23 & .01 & .13 & $.24^{*}$ \\
\hline $\begin{array}{l}\text { Begeleiding bij } \\
\text { persoonlijke problemen }\end{array}$ & $34 *$ & $37 * *$ & .22 & .16 & $.34 * *$ & .16 \\
\hline Theoretische vorming & 01 & .13 & .10 & -.22 &, 09 & .00 \\
\hline Praktische vorming & .16 & .19 & .15 & .01 & .14 & $.25^{\circ}$ \\
\hline Kwaliteit lesmateriaal & $.26^{\circ}$ & $29^{\circ}$ & $.31 * 0$ & .12 & $.25^{\circ}$ & .20 \\
\hline Niveau & .19 & $.27^{\circ}$ & $35 * *$ & .01 & .00 & $.27^{\circ}$ \\
\hline Tempo & .18 & $.23^{\circ}$ & .22 & .01 & .11 & .16 \\
\hline Begeleiding ondenwijs & .13 & .14 & .13 & .08 & .11 & $.25^{\circ}$ \\
\hline Didactische kwaliteit & .13 & .19 & $24^{\circ}$ & -.07 & .03 & .19 \\
\hline Studiebegeleiding & .04 & .07 & -.11 & .09 & 10 & .08 \\
\hline
\end{tabular}

- $0.01<p \leq 0.05$

* $\quad 0.001<p \leqslant 0.01$

Tabel 6.10d Heliomare: Correlaties tussen de variabelen van het scholingsprogramma en de variabelen binnen de factor persoonlijke ontwikkeling $(n=97)$.

$\begin{array}{llllll}\text { persoonlijke } & \text { zelf- } & \text { omgaan met } & \text { sociale } & \text { incasserings- } & \text { functioneren } \\ \text { ontwikkeling } & \text { vertrouwen } & \text { beperkingen } & \text { vardigheden } & \text { vermogen } & \text { arbeidsmarkt }\end{array}$

Aansluiting

scholingsprogramma

.18

$24^{*}$

$24^{*}$

.05

$-.01$

.16

Begeleiding bij

persoonlijke problemen

$26^{\circ}$

33*

$26^{\circ}$

.06

, 08

.06

Theoretische vorming

.06

.09

.08

.01

$-.01$

.19

Praktische vorming

12

.11

15

.06

$-.00$

07

Kwaliteit lesmateriaal

, 03

.00

.08

.10

$-.09$

.09

Niveau

.11

$30 * *$

$-.03$

02

10

Tempo

10

.07

.10

10

.02

$24^{*}$

Begeleiding onderwijs

.03

10

II

.02

$-.13$

.10

Didactische kwaliteit

.12

.11

.17

.01

07

13

Studiebcgeleiding

14

$29 * 0$

.16

.03

.04

01

- $\quad 0.01<p<0.05$

* $\quad 0.001<p<0.01$ 
Tabel 6.10e EEGA: Correlaties tussen de variabelen van het scholingsprogramma en de variabelen binnen de factor persoonlijke ontwikkeling. $(n=73)$

\begin{tabular}{|c|c|c|c|c|c|c|}
\hline & $\begin{array}{l}\text { persoonlijke } \\
\text { ontwikkeling }\end{array}$ & $\begin{array}{l}\text { self- } \\
\text { vertrouwen }\end{array}$ & $\begin{array}{l}\text { omgaan met } \\
\text { beperkingen }\end{array}$ & $\begin{array}{l}\text { sociale } \\
\text { vaardigheden }\end{array}$ & $\begin{array}{l}\text { incasserings. } \\
\text { vermogen }\end{array}$ & $\begin{array}{l}\text { functioneren } \\
\text { arbeidsmarkt }\end{array}$ \\
\hline $\begin{array}{l}\text { Aansluiting } \\
\text { scholingsprogramma }\end{array}$ & $.40 \%$ & $.42 *$ & $.27^{*}$ & $31^{\circ}$ & $.30^{\circ}$ & $31^{\circ}$ \\
\hline $\begin{array}{l}\text { Begeleiding bij } \\
\text { persoonlijke problemen }\end{array}$ & $32 *$ & $.40^{* \bullet}$ & .21 & .20 & $.255^{\circ}$ & $26^{\circ}$ \\
\hline Theoretische vorming & $38 * 0$ & $29^{*}$ & $25^{\circ}$ & $38 * 0$ & $31 * 0$ & $32 * 0$ \\
\hline Praktische vorming & 17 & $24^{*}$ & .03 & 20 & .11 & $30^{\circ}$ \\
\hline Kwaliteit lesmateriaal & $.25 *$ & $.25^{\circ}$ & $.288^{\circ}$ & 02 & $26^{\circ}$ & 19 \\
\hline Niveau & $31 *$ & $41^{*}$ & .13 & .19 & $.299^{\circ}$ & .12 \\
\hline Tempo & $34 * 0$ & $30^{\circ}$ & .21 & $39 \bullet \bullet$ & .19 & $.25^{\circ}$ \\
\hline Begeleiding onderwijs & $26 * 0$ & $32 *$ & .22 & 11 & .20 & .07 \\
\hline Didactische kwaliteit & .13 & II & .12 & .11 & .07 & .08 \\
\hline Studiebegeleiding & $.25^{\circ}$ & $34 * \bullet$ & .19 & .17 & .14 & .20 \\
\hline
\end{tabular}

$0.01<\mathrm{p} \leq 0.05$

* $\quad 0.001<\mathrm{p} \leq 0.01$ 
Tabel 6.11a Hoensbroeck: Multiple lineaire regressie van de factoren gerelateerd aan het scholingsprogramma ten aanzien van de persoonlijke ontwikkeling ( $n=199)$.

Persoonlijke ontwikkeling

$\triangle \mathrm{R}^{2} \quad \beta$

1. Aansluiting scholingsprogramma

2. Begeleiding bij persoonlijke problemen

$.04 * *$

$21^{* 0}$ $0.001<p \leq 0.01$

Tabel 6.11b Werkenrode: Multiple lineaire regressie van de factoren gerelateerd aan het scholingsprogramma ten aanzien van de persoonlijke ontwikkeling ( $\mathrm{n}=58$ ).

Persoonlijke ontwikkeling

$\Delta R^{2} \quad \beta$

1. Aansluiting scholingsprogramma

2. Begeleiding bij persoonlijke problemen

01

03

Tabel 6.11e Sonncheerdt: Multiple lineaire regressie van de factoren gerelateerd aan het scholingsprogramma teo aanzien van de persoonlijke ontwikkeling $(n=77)$.

Persoonlijke ontwikkeling

$\Delta R^{2} \quad \beta$

1. Aansluiting scholingsprogramma

2. Begeleiding bij persoonlijke problemen

$.12 * 0$

$.34 *$

*. $\quad 0.001<p \leq 0.01$

Tabel 6.11d Heliomare: Multiple lineaire regressie van de factoren gerelateerd aan het scholingsprogramma ten aanzien van de persoonlijke ontwikkeling ( $\mathrm{n}=97$ )

Persoonlijke ontwikkeling

$\Delta R^{2} \quad \beta$

I. Aansluiting scholingsprogramma

2. Begeleiding bij persoonlijke problemen

$08^{* *}$

.280

* $\quad 0.001<\mathrm{p} \leq 0.01$

Tabel 6.11e EEGA: Multiple lineaire regressie van de factoren gerelateerd aan het scholingsprogramma ten aanzien van de persoonlijke ontwikkeling $(\mathrm{n}=73)$.

Persoonlijke ontwikkeling

$\Delta R^{2} \quad \beta$

1. Aansluiting scholingsprogramma

2. Begeleiding bij persoonlijke problemen

.04

*. $0.001<p \leq 0.01$ 
Tabel 6.12a Hoensbroeck: Correlaties tussen de factoren gerelateerd aan het scholingsprogramma en de plaatsingsfactoren $(n=199)$

$\begin{array}{llll}\text { Aantal aanpassingen } & \begin{array}{l}\text { Werk op korte } \\ \text { termijn }\end{array} & \begin{array}{l}\text { Werk op lange } \\ \text { termijn }\end{array} & \begin{array}{l}\text { Aansluiting baan bij } \\ \text { scholingsprogramma }\end{array}\end{array}$

Aansluiting

scholingsprogramma

$-.09$

01

07

$18 * 0$

Begelciding bij

persoonlijke problemen

$-01$

11

$19 * *$

.05

$0.001<p \leq 0.01$

Tabel 6.12b Werkenrode: Correlaties tussen de factoren gerelateerd aan het scholingsprogramma en de plaatsingsfactoren $(\mathrm{n}=58)$

$\begin{array}{llll}\text { Aantal aanpassingen } & \begin{array}{l}\text { Werk op korte } \\ \text { termijn }\end{array} & \begin{array}{l}\text { Werk op lange } \\ \text { termijn }\end{array} & \begin{array}{l}\text { Aansluiting baan bij } \\ \text { scholingsprogramma }\end{array}\end{array}$

Aansluiting

scholingsprogramma

.15

$27^{\circ}$

24

$39 *$

Begeleiding bij

persoonlijke problemen

$0.01<p \leq 0.05$

II

$.48 * *$

20

.29

Tabel 6.12e Sonneheerdt: Correlaties tussen de factoren gerelateerd aan het scholingsprogramma en de plaatsingsfactoren $(n=77)$

$\begin{array}{llll}\text { Aantal aanpassingen } & \begin{array}{l}\text { Werk op korte } \\ \text { termijn }\end{array} & \begin{array}{l}\text { Werk op lange } \\ \text { termijn }\end{array} & \begin{array}{l}\text { Aansluiting baan bij } \\ \text { scholingsprogramma }\end{array}\end{array}$

Aansluiting

scholingsprogramma

13

21

$.25 *$

$-.25$

Begeleiding bij

persoonlijke problemen

.14

21

$26^{\circ}$

16

- $0.01<\mathrm{p} \leq 0.05$

Tabel 6.12d Heliomare: Correlaties tussen de factoren gerelateerd aan het scholingsprogramma en de plaatsingsfactoren $(n=97)$

\begin{tabular}{|c|c|c|}
\hline Aantal aanpassingen & $\begin{array}{l}\text { Werk op korte } \\
\text { Iermijn }\end{array}$ & $\begin{array}{l}\text { Werk op lange } \\
\text { termijn }\end{array}$ \\
\hline
\end{tabular}

Aansluiting

scholingsprogramma

.17

14

16

$31^{\circ}$

Begeleiding bij

persoonlijke problemen

$28 * 0$

$25^{\circ}$

.19

$-, 08$

- $0.01<p \leq 0.05$

$0.001<p \leq 0.01$

Tabel 6.12e EEGA:

Correlaties tussen de factoren gerelateerd aan het scholingsprogramma en de plaatsingsfactoren $(n=73)$

Aantal aanpassingen Werk op korte Werk op lange termijn termijn

Aansluiting baan bij scholingsprogramma

Aansluiting

scholingsprogramma

Begeleiding bij

persoonlijke problemen 


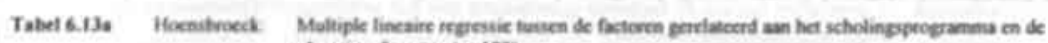
plationgsfoctorts (n-199)

\begin{tabular}{|c|c|c|c|c|c|c|c|c|}
\hline & \multicolumn{2}{|c|}{$\begin{array}{l}\text { Totaal benodigite } \\
\text { aanpassingen }\end{array}$} & \multicolumn{2}{|c|}{$\begin{array}{l}\text { Werk op korte } \\
\text { termijn }\end{array}$} & \multicolumn{2}{|c|}{$\begin{array}{l}\text { Werk op lange } \\
\text { termiji }\end{array}$} & \multicolumn{2}{|c|}{$\begin{array}{l}\text { Aansluiting baan bij } \\
\text { scholingsprogramma }\end{array}$} \\
\hline & $\Delta \mathbf{R}^{x}$ & $\beta$ & $\Delta R^{2}$ & $\beta$ & $\Delta \mathbf{R}^{2}$ & $\beta$ & $\Delta \mathbf{R}^{2}$ & $\beta$ \\
\hline $\begin{array}{l}\text { Aansluiting } \\
\text { scholingsprogramena }\end{array}$ & $\cdot$ & $=$ & - & - & $\cdot$ & - & $.03^{*}$ & $23^{\circ}$ \\
\hline $\begin{array}{l}\text { Begeleiding bij } \\
\text { pernoonlijke probiemen }\end{array}$ & . 01 & .08 & .00 & .03 & .05 & .07 & $.04^{*}$ & $20^{*}$ \\
\hline \multicolumn{9}{|l|}{ - $\quad 0.01<p \leq 0.05$} \\
\hline \multirow[t]{3}{*}{ Tabel 6.13h Wenkenrode: } & \multicolumn{8}{|c|}{ 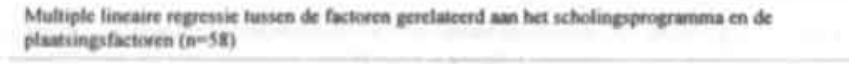 } \\
\hline & \multicolumn{2}{|c|}{$\begin{array}{l}\text { Totaal benodigde } \\
\text { anpassingen }\end{array}$} & \multicolumn{2}{|c|}{$\begin{array}{l}\text { Werk op korte } \\
\text { termijn }\end{array}$} & \multicolumn{2}{|c|}{$\begin{array}{l}\text { Werk op lange } \\
\text { termije }\end{array}$} & \multicolumn{2}{|c|}{$\begin{array}{l}\text { Aansluiting baan bij } \\
\text { scholingsprogramma }\end{array}$} \\
\hline & $\Delta \mathbf{R}^{2}$ & $\beta$ & $\Delta \mathbf{R}^{2}$ & $\beta$ & $\Delta \mathbf{R}^{2}$ & $\beta$ & $\Delta \mathbf{R}^{t}$ & $\beta$ \\
\hline \multirow{2}{*}{$\begin{array}{l}\text { Aansluiting } \\
\text { schotingsprogramma } \\
\text { Begeleiding bij } \\
\text { pernoonlijke problemen }\end{array}$} & $\cdot$ & * & $.08^{\circ}$ & $21^{\circ}$ & - & $\cdot$ & $16 * *$ & $.38 *+$ \\
\hline & 01 & 07 & $07 *$ & $277^{\circ}$ & .02 & .15 & .00 & .07 \\
\hline $0.01 \leq p \leq 0.03$ & $\cdots \quad 6$ & $<p$ & & & & & & \\
\hline \multirow[t]{3}{*}{ Tabel 6.13e Sonnehecrit: } & \multicolumn{8}{|c|}{$\begin{array}{l}\text { Mulipie lineaire regressie tussen de factoren gerelateend an het scholingsprogramma en de } \\
\text { plastsingsfactoren (n=7) }\end{array}$} \\
\hline & \multicolumn{2}{|c|}{$\begin{array}{l}\text { Totaal benodigde } \\
\text { anpassingen }\end{array}$} & \multicolumn{2}{|c|}{$\begin{array}{l}\text { Werk op korte } \\
\text { termijn }\end{array}$} & \multicolumn{2}{|c|}{$\begin{array}{l}\text { Werk op lange } \\
\text { termijn }\end{array}$} & \multicolumn{2}{|c|}{$\begin{array}{l}\text { Aansluiting baan bij } \\
\text { scholingsprogramma }\end{array}$} \\
\hline & $\triangle \mathbf{R}^{2}$ & $\beta$ & $\Delta \mathbf{R}^{2}$ & $\beta$ & $\Delta \mathbf{R}^{2}$ & $\beta$ & $\Delta \mathbf{R}^{2}$ & $\beta$ \\
\hline $\begin{array}{l}\text { Aansluiting } \\
\text { scholingsprognamma }\end{array}$ & $\cdot$ & - & - & $\cdot$ & $.07 \bullet$ & $-.27 *$ & $\cdot$ & - \\
\hline $\begin{array}{l}\text { Begeleiding bij } \\
\text { persoonlijke problemen }\end{array}$ & 01 & 03 & .02 & 14 & .00 & .02 & 00 & .05 \\
\hline \multicolumn{9}{|l|}{ - $\quad 0.01<p \leqslant 0.05$} \\
\hline \multirow[t]{3}{*}{ Tabel 6.13d Heliomare } & \multicolumn{8}{|c|}{$\begin{array}{l}\text { Muhiple lincaire regressie tusien de factoren geretateerd an het scholingoprogramma en de } \\
\text { ptastingsfictoren }(n-97)\end{array}$} \\
\hline & \multicolumn{2}{|c|}{$\begin{array}{l}\text { Totaal benodigde } \\
\text { aanpassingen }\end{array}$} & \multicolumn{2}{|c|}{$\begin{array}{l}\text { Werk op korte } \\
\text { termijn }\end{array}$} & \multicolumn{2}{|c|}{$\begin{array}{l}\text { Werk op lange } \\
\text { termijn }\end{array}$} & \multicolumn{2}{|c|}{$\begin{array}{l}\text { Aansluiting baan bij } \\
\text { scholingsprogramma }\end{array}$} \\
\hline & $\Delta R^{2}$ & $\beta$ & $\Delta \mathbf{R}^{3}$ & $\beta$ & $\Delta \mathbf{R}^{2}$ & $\beta$ & $\Delta \mathbf{R}^{2}$ & $\beta$ \\
\hline \multirow{2}{*}{$\begin{array}{l}\text { Aansluiting } \\
\text { scholingsprogramma } \\
\text { Begeleidiug bij } \\
\text { persoonlijke problemen }\end{array}$} & - & - & - & - & - & - & $.10^{\circ}$ & $37 *$ \\
\hline & $05^{*}$ & 22 & $.04^{*}$ & 21 & 00 & .06 & 04 & 20 \\
\hline - $\quad 0.01<p \leq 0.05$ & & & & & & & & \\
\hline Tabeis,ile EEGA: & $\begin{array}{l}\text { Multipik } \\
\text { platsin }\end{array}$ & sine res & i) & toren & aterd an th & holing: & pograntuma es & \\
\hline & $\begin{array}{l}\text { Total b. } \\
\text { anpassi }\end{array}$ & igde & $\begin{array}{l}\text { Werk on } \\
\text { termijn }\end{array}$ & & $\begin{array}{l}\text { Werk op } \\
\text { termijn }\end{array}$ & & $\begin{array}{l}\text { Aansluit } \\
\text { scholing }\end{array}$ & ramma \\
\hline & $\Delta \mathbf{R}^{2}$ & B & $\mathbf{A} \mathbf{R}^{2}$ & B & $\Delta \mathbf{R}^{2}$ & $\beta$ & $\Delta \mathbf{R}^{2}$ & $\beta$ \\
\hline $\begin{array}{l}\text { Aansluiting } \\
\text { scholingsprogramma }\end{array}$ & $\cdot$ & * & $=$ & - & - & - & & \\
\hline $\begin{array}{l}\text { Begeleiding bij } \\
\text { persoealijke problemen }\end{array}$ & e2 & 04 & $07 *$ & 27 & .04 & 19 & & \\
\hline
\end{tabular}




\begin{tabular}{|c|c|c|c|c|}
\hline \multirow[t]{3}{*}{$\begin{aligned} & \text { Hoensbroeck: } \text { Log } \\
& \text { cn a } \\
& \text { onty }\end{aligned}$} & \multicolumn{4}{|c|}{$\begin{array}{l}\text { Logistische regressievergelijking van de onafhankelijke persoonsgebonden factoren leeftijd } \\
\text { cn arbeidsverleden, aansluiting van scholingsprogramma en de factor persoonlijke } \\
\text { ontwikkeling ten aanzien van werk op korte en op lange termijn ( } n=199)\end{array}$} \\
\hline & \multicolumn{2}{|c|}{ Werk op korte termijn } & \multicolumn{2}{|c|}{ Werk op lange termijn } \\
\hline & B (S.E.) & $\operatorname{Exp}(B)$ & B (S.E.) & $\operatorname{Exp}(B)$ \\
\hline Leeftijd & $-.08(.03)^{* *}$ & $93 * t$ & $-.05(.03)$ & 95 \\
\hline Arbeidsverleden & $.84(.61)$ & 2.32 & $.03(.74)$ & 1.04 \\
\hline Aansluiting scholingsprogramma & $.01(.04)$ & 1.01 & $.04(.04)$ & .96 \\
\hline Persoonlijke ontwikkeling & $.08(.05)$ & 92 & $.06(.06)$ & .94 \\
\hline
\end{tabular}

*. $\quad 0.001<p \leq 0.01$

\begin{tabular}{|c|c|c|c|c|}
\hline \multirow[t]{3}{*}{ Tabel 6.17b } & \multicolumn{4}{|c|}{$\begin{array}{l}\text { Logistische regressievergelijking van de onafhankelijke persoonsgebonden factoren leeftijd } \\
\text { en arbeidsverleden, aansluiting van scholingsprogramma en de factor persoonlijke } \\
\text { ontwikkeling ten aanzien van werk op korte en op lange termijn (n=58) }\end{array}$} \\
\hline & \multicolumn{2}{|c|}{ Werk op konte termijn } & \multicolumn{2}{|c|}{ Werk op lange termijn } \\
\hline & B (S.E.) & $\operatorname{Exp}(B)$ & B (S.E.) & $\operatorname{Exp}(B)$ \\
\hline Leeftijd & $-.24(.13)$ & .79 & $-.08(.13)$ & 92 \\
\hline Arbeidsverleden & $2.10(1.07)^{*}$ & $8.13^{\circ}$ & $.72(1.02)$ & 2.05 \\
\hline Aansluiting scholingsprogramma & $.16(.10)$ & 85 & $.16(.10)$ & 85 \\
\hline Persoonlijke ontwikkeling & $.07(.10)$ & .93 & $.06(.11)$ & .94 \\
\hline
\end{tabular}

- $0.01<p \leq 0.05$

Tabel 6.17e Sonneheerdt: Logistische regressievergelijking van de onathankelijke persoonsgebonden factoren leeflijd en arbeidsverleden, aansluiting van scholingsprogramma en de factor persoonlijke ontwilkeling ten aanzien van werk op korte en op lange termijn ( $n=77$ )

\begin{tabular}{|lcccc|}
\hline & \multicolumn{2}{c}{ Werk op korte termijn } & Werk op lange termijn & \\
& B (S.E.) & Exp (B) & B (S.E.) & Exp (B) \\
\hline Leeftijd & $-.03(.05)$ & .97 & $-.08(.05)$ & .93 \\
Arbeidsverleden & $.57(.77)^{*}$ & $1.76^{*}$ & $1.01(.81)$ & 2.74 \\
Aansluiting scholingsprogramma & $.10(.05)$ & .90 & $.11(.05)^{*}$ & $.90^{*}$ \\
Persoonlijke ontwikkeling & $.03(.08)$ & .97 & $.11(.09)$ & .90 \\
\hline
\end{tabular}

- $0.01<p \leq 0.05$ 


\begin{tabular}{|c|c|c|c|c|}
\hline \multirow[t]{3}{*}{ Tabel 6.17d Heliomare: } & \multicolumn{4}{|c|}{$\begin{array}{l}\text { Logistische regressievergelijking van de onafhankelijke persoonsgebonden factoren leeflijd } \\
\text { en arbeidsverleden, aanstuiting van scholingsprogramma ende factor persoonlijke } \\
\text { ontwikkeling ten aanzien van werk op korte en op lange termijn ( } n=97 \text { ) }\end{array}$} \\
\hline & \multicolumn{2}{|c|}{ Werk op korte termijn } & \multicolumn{2}{|c|}{ Werk op lange termijn } \\
\hline & B (S.E.) & $\operatorname{Exp}(B)$ & B (S.E) & $\operatorname{Exp}(B)$ \\
\hline Leefijid & $.01(.03)$ & 1.01 & $.04(.04)$ & 1.04 \\
\hline Arbeidsverleden & $-1.07(.62)$ & .34 & $.68(.64)$ & 51 \\
\hline Aansluiting scholingsprogramma & $.06(05)$ & 95 & $.06(.05)$ & 94 \\
\hline Persoonlijke ontwikkeling & $.01(.07)$ & 1.00 & $.05(.08)$ & 1.05 \\
\hline
\end{tabular}

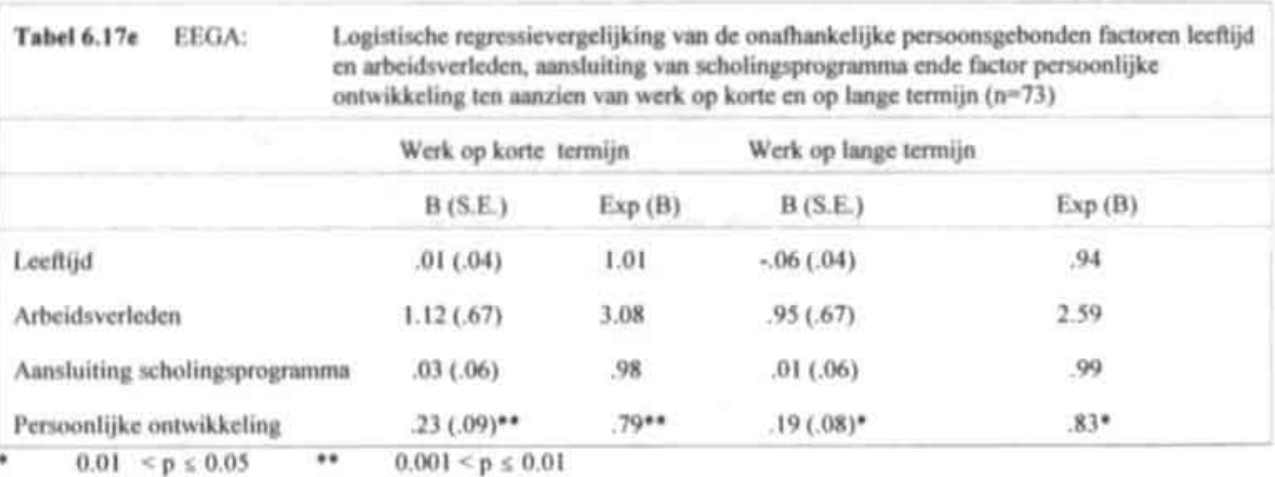




\section{NAWOORD}

Op het einde van de afronding van dit proefschrift, een moment van terugblik op de totstandkoming ervan.

De totstandkoming had nooit kunnen plaatsvinden als Dorine er niet was geweest. Dorine, je hebt mij bij dit onderzoek betrokken. Samen hebben we de gegevens verzameld die mede tot dit proefschrift hebben geleid. Dorine, bedankt voor je onschatbare hulp, je grenzeloze humor en optimisme. Onze gezamenlijke discussies, gezellige etentjes en onze nachten in het waterbed zal ik niet gauw vergeten.

De totstandkoming had nooit kunnen plaatsvinden als de Federatie van Arbeidsintegratiecentra voor mensen met een arbeidshandicap niet hun medewerking hadden verleend aan dit onderzoek. Hoensbroeck, Werkenrode, Sonneheerdt. Heliomare en EEGA, bedankt voor jullie volle medewerking, jullie gastvrijheid en jullie positieve en bijzondere welwillende bijdragen aan dit onderzock.

De totstandkoming van dit proefschrift had nooit kunnen plaatsvinden als niet een heel groot deel van de oud-cursisten van de reïntegratiecentra toestemming gaven mee te willen werken aan dit onderzoek. Dit geldt eveneens voor een aantal werkgevers die oud-cursisten in dienst hebben genomen. Dit dankwoord bereikt jullie niet, maar is hopelijk aangekomen bij het toesturen van een samenvatting van de resultaten.

In de meeste gevallen gaat een studie aan een wetenschappelijke instelling vooraf aan de totstandkoming van een proefschrift. Zo ook in mijn situatie. Ik begon echter pas aan mijn studie in een stadium dat anderen aan een tweede hypotheek gaan denken. Paul, Bas en Alda, die mogelijkheid heb ik mede door jullie kunnen benutten. Bedankt daarvoor.

De totstandkoming had misschien weliswaar plaatsgevonden, maar gegarandecrd op een andere wijze, als ik niet tijdens mijn studie deel had uitgemaakt van 'het statistisch studiegenootschap'. José, Jeanine en met name Liezeth, onze urenlange discussies over statistiek, de studie, de wereld, de wetenschap en daarnaast de wandelingen en etentjes hebben een duidelijke en zeer positieve stempel gedrukt op mijn onderzoeksleven op de universiteit na afloop van onze studieperiode. Bedankt daarvoor!

De totstandkoming had nooit plaatsgevonden als niet een aantal mensen mij voortdurend hadden overtuigd dat ik 'het kon' en dat ik 'het gewoon moest doen'. Marie-louise, Marike, Rob, André, IJmert, Guus, Agnes, Afke, Ad, Isel, Miriam, Nathalie, Ghislaine, bedankt voor jullie ondersteuning en optimisme. 
Veel van de ideeën zoals die met name in hoofdstuk 1 van het proefschrift zijn verwoord, zijn mede totstandgekomen tijdens de vele discussies die ik heb gevoerd met mijn 'buitenlandse' collega's. Fred, Donal, Franz en Gustav, dank daarvoor.

Een speciaal woord voor Peter. Peter, in al die jaren heb je me altijd ondersteund, hebben we veel samengewerkt, maar ook samen de nodige pilsjes genuttigd en diepe inzichten in het menselijk functioneren uitgewisseld. Jij hebt er mede voor gezorgd ik ondanks alle drukte toch voldoende tijd en ruimte had om dit proefschrift te voltooien. Bedankt voor je bijdrage aan de totstandkoming van dit proefschrift.

Laat ik in mijn totstandkoming van dit proefschrift niet de juffrouwen van de lagere meisjesschool vergeten. Jullie eeuwige streven het beste uit ons te halen en ons te overtuigen dat ook meisjes ver kunnen komen, heeft er toe bijgedragen dat ik ben waar $i k$ nu ben. Met name juffrouw Verstappen en juffrouw Wagemans, ik hoop dat ik dat nu in jullie ogen heb waargemaakt. bedankt daarvoor!

In mijn totstandkoming van dit proefschrift ga ik nog een stap verder terug alvorens weer terug te keren naar het heden. Pap, mam, bedankt dat ik heb mogen studeren. Ik weet wat voor een opoffering het voor jullie heeft betekend. Grote zussen, bedankt voor jullie geloof in je kleine zusje en grote broers, bedankt voor jullie goede voorbeeld.

Om een proefschrift tot stand te laten komen heb je een promotor nodig, in mijn geval zelfs twee promotores. Wim, je 'snelle' strategische inzicht en je kritische vragen hebben een wezenlijke en belangrijke bijdrage geleverd aan dit proefschrift. Bedankt daarvoor! Frans, jouw ondersteuning is niet in woorden uit te drukken. Dat doe ik dus ook niet, dat weet je wel.

En verder, iedereen die ik niet bij name heb genoemd, bedankt! 


\section{CURRICULUM VITAE}

Brigitte van Lierop is geboren op 9 januari 1960 in Weert. Na het behalen van haar HAVO-diploma op het Bisschoppelijk College te Weert startte zij in Utrecht met de lerarenopleiding. $\mathrm{Na}$ het behalen van een tweedegraadsbevoegdheid Biologie en Scheikunde in 1984, slaagde zij vervolgens in 1986 voor haar bevoegdheid om Lichamelijke Opvoeding te kunnen geven.

Vanaf 1984 was zij werkzaam als docente aan verschillende opleidingen, variërend van het hoger beroepsonderwijs tot categoriale mavo's.

Tussen 1992 en 1994 volgde zij, naast haar werk als docente, de studie Gezondheidswetenschappen in Maastricht.

Vanaf 1995 werkte zij als onderzoeksmedewerker en vanaf 1997 als universitair docent aan de Universiteit Maastricht, Faculteit Gezondheidswetenschappen, vakgroep Beleid, Economie en Organisatie van Zorg.

Vanaf 1997 heeft zij de opleiding Arbeidsrehabilitatie wetenschap gecoördineerd en is zij verantwoordelijk voor de internationale post hogere onderwijscursus Higher Management Development Course van het Europees Platform voor Vocational Rehabilitation.

$\mathrm{Zij}$ is tevens lid van de redactie van het Maandblad Reīntegratic. 


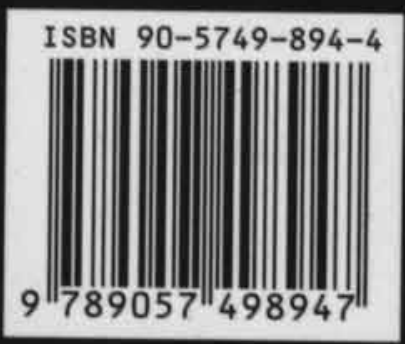

